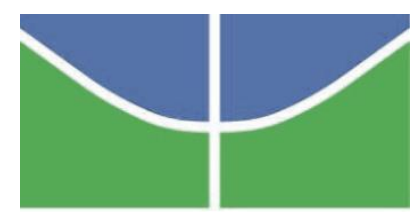

UNIVERSIDADE DE BRASÍLIA

INSTITUTO DE CIÊNCIAS SOCIAIS

DEPARTAMENTO DE ANTROPOLOGIA

PROGRAMA DE PÓS-GRADUAÇÃO EM ANTROPOLOGIA SOCIAL

KRISLANE DE ANDRADE MATIAS

LEI, JUSTIÇA E JUDICIALIZAÇÃO DE CONFLITOS A PARTIR DE RELATOS DE MULHERES NO DISTRITO FEDERAL 


\section{LEI, JUSTIÇA E JUDICIALIZAÇÃO DE CONFLITOS A PARTIR DE RELATOS DE MULHERES NO DISTRITO FEDERAL}

Dissertação de mestrado apresentada ao Programa de Pós-Graduação em Antropologia Social da Universidade de Brasília, como parte dos requisitos para a obtenção do título de Mestra em Antropologia Social.

ORIENTADOR: Daniel Schroeter Simião 


\section{LEI, JUSTIÇA E JUDICIALIZAÇÃO DE CONFLITOS A PARTIR DE RELATOS DE MULHERES NO DISTRITO FEDERAL}

Esta dissertação foi julgada adequada para a obtenção do título de Mestre em Antropologia Social e aprovada em sua forma final pelo Orientador e pela Banca Examinadora.

Orientador:

Prof. Dr. Daniel Schroeter Simião, UnB

Banca Examinadora:

Prof. Dr. Daniel Schroeter Simião (DAN/UnB) - Presidente

Dra . Wânia Pasinato Izumino (ONU Mulheres) - Examinadora Externa

Prof. Dr. Luís Roberto Cardoso de Oliveira (DAN/UnB) - Examinador Interno

Prof $^{\mathrm{a}}$. Dr ${ }^{\mathrm{a}}$. Kelly Silva (DAN/UnB) - Suplente

Brasília, 31 de agosto de 2015. 
Para as mulheres que aceitaram compartilhar suas histórias neste trabalho. Para a minha avó, Dejanira dos Santos Andrade.

Para a minha mãe, Alzenete de Andrade Matias. 
Escrevo neste instante com algum prévio pudor por vos estar invadindo com tal narrativa tão exterior e explícita. De onde, no entanto, até sangue arfante de tão vivo de vida poderá quem sabe escorrer e logo se coagular em cubos de geleia trêmula. Será essa história um dia meu coágulo? Que sei eu. Se há veracidade nela - é claro que a história é verdadeira embora inventada - que cada um a reconheça em si mesmo porque todos nós somos um e quem não tem pobreza de dinheiro tem pobreza de espírito ou saudade por lhe faltar coisa mais preciosa que ouro - existe a quem falte o delicado essencial.

(Clarice Lispector - A Hora da Estrela) 


\section{AGRADECIMENTOS}

Além de compromisso, dedicação, trabalho e noites em claro, esta dissertação também é feita de muitos agradecimentos. Então, vamos lá!

Pelos incríveis últimos sete anos que vivi na Universidade de Brasília. Agradeço a todas as possibilidades que surgiram ao longo da minha trajetória nessa Universidade, às oportunidades a que tive acesso e, consequentemente, agradeço pela pessoa que me tornei hoje. Agradeço à Universidade por tudo que ela me deu: a formação que recebi, por estimular meus interesses intelectuais, por me ensinar novos métodos de pensar, pelas pessoas incríveis que apareceram no meu caminho, pelas pessoas que se tornaram parte da minha vida, por ter se tornado um dos meus lugares preferidos no mundo.

Segundo Mariza Peirano (2008), a orientação é um tipo de relação que nunca tem fim. Sou mais que grata ao meu orientador, Daniel Schroeter Simião, que me acompanha desde a graduação. Durante estes últimos anos ele soube me incentivar, respeitar minhas decisões e análises, manter o diálogo mesmo quando nossas opiniões se mostravam diferentes. Agradeço por ter me ajudado a permanecer em pé, pela delicadeza nos momentos difíceis, por ter acreditado no meu trabalho e por ter sido fundamental para que essa dissertação fosse concluída.

Agradeço ao professor Luís Roberto Cardoso de Oliveira pelas oportunidades de diálogo, pelo incentivo, pela constante receptividade. Agradeço a Wania Pasinato Izumino e Kelly Silva pelo diálogo. Muitíssimo obrigada por terem aceitado participar desse processo e pelas considerações sobre esta dissertação. Certamente, além da responsabilidade, tê-las/os como avaliadoras/es é um privilégio.

Aos professores e professoras da Universidade de Brasília, agradeço a minha formação. Lisa Minari Hargreaves, Patrice Schuch, Fátima Rodrigues Makiuchi, Karenina Vieira Andrade, Valeria Viana Labrea, Luiz Eduardo de Lacerda Abreu, Soraya Resende 
Fleischer, Rita Laura Segato, Marcela Stockler Coelho de Souza, Martin Adamec, José Jorge de Carvalho, Haydeé Caruso, Maria Stela Grossi Porto, Maristela Rossato, Flávio Versiani, Charles Teixeira, Carmenísia Jacobina Aires Gomes, André de Barros Borges e tantas/os outras/os professoras/es que foram tão importantes ao longo de todos estes anos.

Agradeço aos/as servidores/servidoras e funcionários/as do DAN, ICS e da Universidade de Brasília pela disposição em resolver problemas, pela habilidade em encontrar soluções. Agradeço também ao CNPq que, através da bolsa de estudos, tornou possível a realização desta pesquisa.

Agradeço imensamente ao Ben-Hur Viza, juiz titular do Juizado de Violência Doméstica e Familiar contra a Mulher do Núcleo Bandeirante, pela recepção calorosa com a qual nos acolhe desde 2011, pela disponibilidade em dialogar, por permitir que esta pesquisa fosse realizada a partir de dados daquele juizado. Sou muito grata à Cristiane Moroishi, João Wesley Domingues, Marijara da Conceição Mendes e toda a equipe de servidoras/es que trabalha neste Juizado, no Centro Judiciário da Mulher e no Arquivo do Fórum. Muito obrigada pelo acolhimento e disposição com que me receberam.

Ao Eduardo do Couto e Silva. Por ser um físico que se convenceu a contratar uma estagiária que cursava antropologia e, através deste estágio, ter me encorajado a prosseguir na carreira científica. Agradeço pela empolgação, motivação, organização, dedicação e inspiração.

Angela Maria Baptista, Elaine Amorim, Jorge Bruno Souza, Leonardo Leocádio da Silva, Marco Paulo Froés Schettino, Maria Fernanda Paranhos de Paula e Silva, antropólogas/os que compõe a assessoria pericial da $6^{\mathrm{a}}$ CCR da PGR/MPF. Agradeço pelo estágio, por todo o aprendizado, apoio e incentivo, inclusive quando eu participava da seleção para esse programa. Obrigada pelo ânimo, pela inspiração, por me mostrarem novas possibilidades dentro da antropologia. 
Brunner Nuner, Julia Sakamoto, Julia Arcanjo, Graciela Froelich, Fabiano Souto, Natália Silveira, Janaína Fernandes, Carlos Oviedo, Raoni Giraldin, Rosana Castro, Guilherme Moura, Thaisa Coelho Tiba, Bianca Alves Silveira, João Francisco Kleba Lisboa, Izabel Ibiapina, Lillyane Silva de Farias, Ligia Fonseca e Leonardo Alves, colegas de mestrado e da Katacumba. Muito obrigada pela convivência, pelos cafés, pelas conversas, pelo apoio mútuo.

Talita Viana Neves, Isabel Naranjo, Ana Cândida Pena, Raysa Martins, Paloma Maroni, Mariana Guimarães, Francisco Paolo Vieira Miguel, Emilia Juliana Ferreira, Alexandre Fernandes muito obrigada por terem me "adotado". Tenho certeza que conhecer vocês e fazer parte do nosso grupo de "antropólogxs fofoqueirxs" está entre as melhores coisas que aconteceram comigo durante o mestrado. Talitinha sempre iluminada, doce, inspiradora; Isa tão corajosa, inteligente e confiante; Aninha, sempre perspicaz e animadora; Palometx por todo o carinho, por sempre estar por perto; Mari pela generosidade e amizade, por ter se tornado uma "amiga-irmã"; Chiquinho por me contestar, me fazer duvidar e sempre querer melhorar; Ray "raio de sol” pelo apoio, por me ajudar a ir em frente; Mimi por todo o carinho e amizade; Alê por todas as trocas, pelo carinho, pelas valiosas sugestões. Ao Júlio César Souza, o "agregado" com quem eu sempre posso contar. Obrigada pelos momentos incríveis, pelas trocas, companhia, carinho, amizade, inspiração e por tornarem Brasília um lugar tão mais agradável.

À Ranna Mirthes Sousa Correa pela disponibilidade, amizade, leveza, bom humor, companheirismo, confiança e parceria desde a graduação.

As “abiugas” Ana Julia Tomasini, Anna Bárbara Araújo, Elaine Rosa, Flora Campos, Izabela Amaral Caixeta, Karol Pacheco, Nathalia Silva da Costa, Raquel Kojoroski, que mesmo longe, estão sempre presentes. Pelos inúmeros sorrisos, por sempre insistirem nos convites apesar das minhas ausências. 
Carla Rocha Coelho, por ser a pessoa mais bondosa que eu já conheci. Por me ajudar, inspirar e mostrar o quão melhor eu posso ser e fazer. Obrigada por todos os exemplos cotidianos, Carlinha. Obrigada também pela ajuda neste trabalho.

Juliana França Varella, por compartilhar as disciplinas, a SOCIUS, a UnB, o estágio, a seleção para o mestrado, a ansiedade, o carnaval, as festas. Por entender minhas reclamações dificuldades, crises de final de semestre e sempre me lembrar que "vai dar certo". Ju, ainda quero ser um pouquinho como você: inspiradora, inteligente, dedicada, doce.

Jocelina Laura Segato de Carvalho, sempre incrível e animadora. Joce, obrigada por permanecer, por insistir nessa amizade e sempre lembrar que a minha primeira impressão estava errada. Obrigada também pelo fundamental "abrigo-exílio" nas últimas semanas de escrita; Fidel, Frida, Mimi e Luigi muito me alegraram nesse período.

Mariana da Silva Mourão, “irmã-de-pacto”. Obrigada Maricotinha por estar sempre presente desde a nossa primeira aula de Introdução à Sociologia. Pelas ligações e desabafos, por ter me motivado de todas as formas possíveis, por me inserir no "mundo das terapias naturais", por sempre me fazer sorrir e me apresentar novidades. Por ter se convidado para tomar um café durante meu "exílio" porque achava que eu precisava de ânimo para terminar o trabalho e porque é isso que as amigas fazem.

Bruno Rocha, Iorrana Lisboa Camboim e Karoline Lima Sirqueira tão incríveis e que sempre trazem coisas boas pra minha vida. Brunete, Iô e Karol: espero tê-lxs por perto por muitos e muitos anos. Alessandra Olinda, pelos vários convites e por me lembrar que existe vida após a dissertação. Gabriella Rosa, Larissa Pessoa, Tham Borges, Juliana Borgê, muito obrigada por permanecerem durante toda essa nossa jornada. Ao Caio e ao Rafael, pelo incentivo e força.

Aos que acompanharam de perto os escritos que compõe este trabalho: Talita Viana Neves, Emília Juliana Ferreira, Mariana da Silva Mourão, Carla Rocha Coelho, Ranna 
Mirthes Sousa Correa, Nicholas Moreira Borges de Castro, Anna Bárbara Araújo: Vocês me entusiasmaram, teceram ótimas pontuações, trouxeram novas perspectivas a este trabalho... Muitíssimo obrigada por toda a gentileza e atenção!

Débora Miranda, obrigada pela valiosa contribuição na revisão e formatação desta dissertação. Agradeço por você cultivar o "deboísmo" e acreditar na conclusão deste trabalho, mesmo com prazos tão corridos.

Luciana França, minha melhor vizinha, amiga e fisioterapeuta: muito obrigada por ser minha “amiga-irmã-companheira", por compartilhar a vida comigo desde 2002.

À minha família, que me suportou ao longo de todo este processo. Muitíssimo obrigada também por aceitarem assumir meus trabalhos domésticos nos últimos meses, rs. Mamãe, Kaka, Márcio, Jorge obrigada pelo apoio incondicional, mesmo quando eu escolho trilhar caminhos tão inesperados. Obrigada por me amarem mesmo assim. Ao meu pai e ao meu avô Olegário, obrigada pelas inspirações, por permanecerem vivos em nossas lembranças. À minha avó, Dejanira dos Santos Andrade, por me inspirar a acreditar em uma vida melhor, por todas as lutas que enfrentou.

Minha incrível irmã, Klesia de Andrade Matias, a quem admiro profundamente. Eu já sei que você merecia uma página inteira de agradecimentos por sempre ter me apoiado incondicionalmente, inclusive nos momentos mais difíceis deste mestrado. Muito, muito, muito obrigada, "rimã"!

Ao Nicholas Moreira Borges de Castro. Por não desistir e não me deixar desistir. Por ter acreditado neste trabalho, por me ajudar a conseguir. Por todas as leituras, releituras e correções. Por ter se resignado e compreendido minhas ausências ao longo dos últimos meses. Nic, obrigada por me fazer ver/sentir/compreender que "o amor é um calafrio doce, um susto sem perigos", por compartilhar uma vida e vários sonhos comigo. 
A todas as mulheres que fizeram parte desta pesquisa. Muito obrigada por me receber, por terem confiado em mim, por terem aceitado compartilhar suas histórias. 


\section{RESUMO}

Esta dissertação analisa a percepção de mulheres que passaram por situações de violência doméstica e familiar e acionaram a Lei Maria da Penha. O objetivo é compreender o tratamento oferecido pelo sistema de justiça criminal a partir das percepções das mulheres que utilizaram este sistema e que, em algum momento, optaram por arquivar os processos. $\mathrm{O}$ itinerário deste trabalho começou nos arquivos do Juizado de Violência Doméstica e Familiar contra a Mulher do Fórum do Núcleo Bandeirante, conhecido por ter implementado projeto piloto no atendimento a mulheres em situação de violência no Distrito Federal. As investigações de campo tiveram como base informações produzidas a partir do acesso aos processos arquivados. Em seguida, foram realizadas entrevistas com mulheres requerentes de alguns desses processos. Ao final do percurso, a partir da análise destes dados argumenta-se que apesar de essas mulheres terem acessado um projeto piloto reconhecido pelo atendimento às mulheres em situação de violência isso não significa que elas considerem que suas demandas foram atendidas pelo Estado. Nesse sentido, as análises deste trabalho refletem sobre como características subjetivas presentes durante todo o atendimento no sistema de justiça influenciam a percepção das mulheres sobre o tratamento e a legislação que acionaram.

Palavras-chaves: Antropologia do Direito. Lei Maria da Penha. Lei 11.340/2006. Violência Doméstica e Familiar contra Mulheres. 


\begin{abstract}
This dissertation analyzes the perception of women who have been through situations of domestic violence and triggered the Maria da Penha Law. The goal is to understand the treatment offered by the criminal justice system from the perceptions of women who used this system and that at some point, they have chosen to archive processes. The itinerary of this work began in the archives of the Domestic and Family Violence against Women Court Center of Núcleo Bandeirante, known to have implemented pilot project caring for women in situations of violence in Distrito Federal. The field investigations were based on information gathered from access to archived files. Then interviews were conducted with women applicants of some of these processes. At the end of the route, from the analysis of these data it is argued that although these women have accessed a pilot project recognized by assisting women victims of violence does not mean that they consider that their demands were met by the State. In this sense, the analysis of this work reflect on subjective characteristics present throughout the service in the justice system influence the perception of women about the treatment and the legislation they triggered.
\end{abstract}




\section{LISTA DE ABREVIATURAS}

AMB: Área Metropolitana de Brasília

BDTD: Biblioteca Digital Brasileira de Teses e Dissertações

BO: Boletim de Ocorrência

CAPS: Centros de Atendimento Psicossocial

CF: Constituição Federal

CJM: Centro Judiciário da Mulher

CNH: Carteira Nacional de Habilitação

CNJ: Conselho Nacional de Justiça

CPMI: Comissão Parlamentar Mista de Inquérito

CRAS: Centro de Referência de Assistência Social

DAN: Departamento de Antropologia

DDM: Delegacia de Defesa da Mulher

DEAM: Delegacia Especial de Atendimento à Mulher

DF: Distrito Federal

GDF: Governo do Distrito Federal

ICS: Instituto de Ciências Sociais

JECrim: Juizado Especial Criminal

JVDFM: Juizado de Violência Doméstica e Familiar contra a Mulher

LMP: Lei Maria da Penha

MP: Ministério Público

MPDFT: Ministério Público do Distrito Federal e Territórios

MPU: Medida Protetiva de Urgência

NAFAVD: Núcleo de Atendimento à Família e aos Autores de Violência Doméstica 
NB: Núcleo Bandeirante

PDAD: Pesquisa Distrital por Amostra de Domicílios

PPGAS: Programa de Pós-Graduação em Antropologia Social

Pró-Vítima: Programa de atendimento às pessoas em situação de violência

RA: Região Administrativa

RG: Registro Geral

SAM: Seções de Atendimento à Mulher

SAAN: Setor de Armazenagem e Abastecimento Norte

SEJUS: Secretaria de Justiça

SPM: Secretaria de Políticas para as Mulheres

STF: Supremo Tribunal Federal

TCC: Trabalho de Conclusão de Curso

TJDFT: Tribunal de Justiça do Distrito Federal e Territórios

UnB: Universidade de Brasília 


\section{SUMÁRIO}

INTRODUÇÃO 10

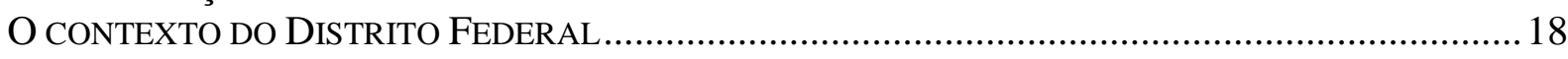

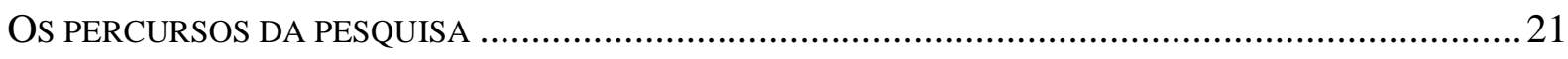

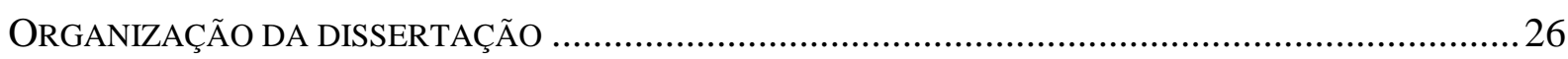

CAPÍTULO 01 - SOBRE VIOLÊNCIA DOMÉSTICA E O ACESSO AO SISTEMA DE

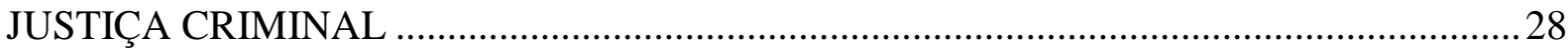
1.1 — TRAJETÓRIA DO CONCEITO DE VIOLÊNCIA DOMÉSTICA E FAMILIAR CONTRA MULHERES NO

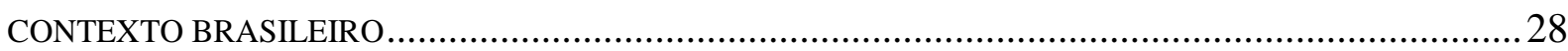

1.2 — PODER JUDICIÁRIO, HONRA E A JUDICIALIZAÇÃO DAS RELAÇÕES ....................................36

1.3 - OS CAMINHOS DA CRIMINALIZAÇÃO DA VIOLÊNCIA DOMÉSTICA E FAMILIAR CONTRA

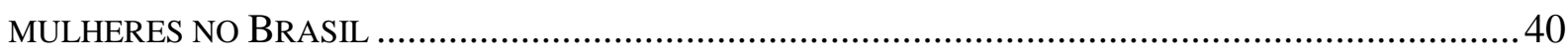

1.4 — JuIZADOS ESPECIAIS CÍvEIS E CRIMINAIS (JEC E JECRIM), ......................................45

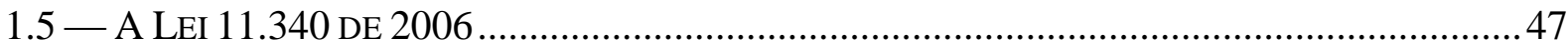

1.6 - ANTROPOLOGIA DO DIREITO: RECONHECIMENTO, LÓGICA E LIMITES DA AÇÃO JUDICIAL 50 CAPÍTULO 02 - OS CAMINHOS DA PESQUISA E OS CONTORNOS DA

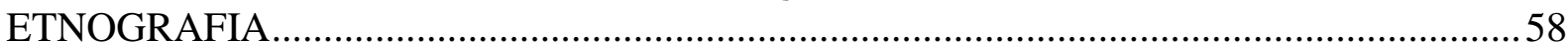

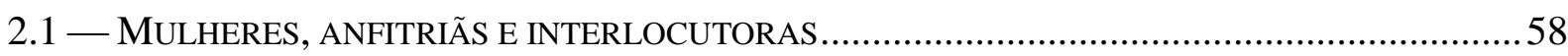

2.2 - SOBRE NEGOCIAÇÕES E RELAÇÕES ESTABELECIDAS EM CAMPO .....................................60

2.3 - OS PERCURSOS E DILEMAS DO CAMPO E OS NOVOS CAMINHOS DA PESQUISA...................66

2.4 - OS IMPONDERÁVEIS DA VIDA REAL E OS NOVOS RECORTES DA PESQUISA........................78

CAPÍTULO 03 - SOBRE OS (DES)CAMINHOS PERCORRIDOS NAS DOZE

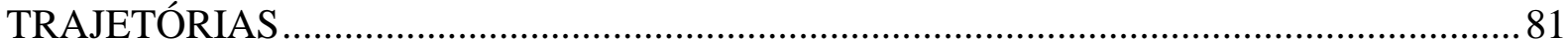

3.1 — ANA Clara - “Aí DA SEGUNDA VEZ Eu LEVEI A GRAVAÇÃo, PASSEI PARA UM CD E

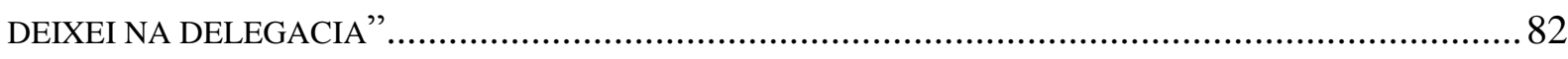

3.2 - AliCE - "PRATICAMENTE VIRARAM PARA A MINHA CARA E ME MANDARAM IR PARA CASA. SE TIVESSE QUE ACONTECER ALGUMA COISA, TINHA ACONTECIDO”. ............................. 87

3.3 - CARolina - "A DElegada falou PARA ElE VIR AQUi E TIRAR tudo DELE. Ele Veio E

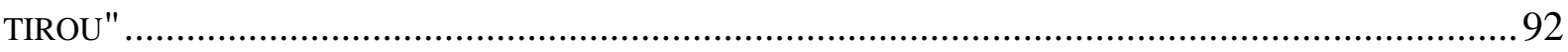

3.4 - LYGIA — “EU PENSAVA QUE... EU IA CHAMAR A POLÍ́CIA E ELE IA SER PRESO” ..............96

3.5 - Lia - "Mas Parece Que Você gosta de APANHAR, né? Você deVE GOSTAR, PORQUe NÃO É POSSÍVEL. A GENTE TEM MAIS O QUE FAZER, A GENTE TRABALHA!” .............................. 101

3.6 - Clarice E JOANA — "ElE DIZIA QUE NÃO TINHA NADA A PERDER E QUE TINHA MUITOS

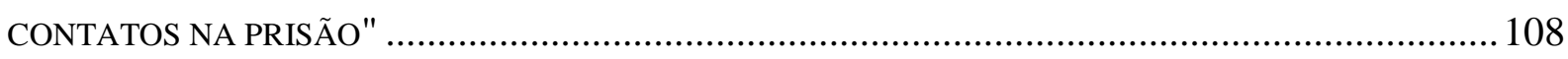

3.7 - LORENA - "LÁ NA DELEGACIA ELE ME DISSE: - VOCÊ VAI VER, QUANDO CHEGAR LÁ EM CASA, O QUE EU VOU FAZER COM VOCÊ ESSA NOITE!" 


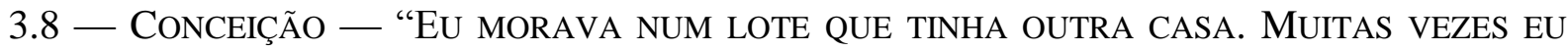
GRITAVA E A VIZINHA VINHA SOCORRER”.

3.9 - NADINE — “O QUE MAIS ME MOTIVOU A IR A DELEGACIA FOI A MINHA MÃE, ENCHENDO O SACO. NA HORA EU NEM PENSEI NISSO". 116

3.10 - HILdA — "Porque NÃO ERA MAIS SÓ COMIGO, ERA COM A CRIANÇA TAMBÉM! ELE JÁ ESTAVA ACHANDO QUE PODIA AGREDIR A CRIANÇA TAMBÉM!”

3.11 - RACHEL - "EU TINHA MEDO DELE VIR ATRÁS, EU TINHA MEDO DELE TOMAR A CRIANÇA".

3.12 — MARINA — "ElE ESTAVA EM SÃ CONSCIÊNCIA. EU TENHO CERTEZA ABSOLUTA" ....... 125

CAPÍTULO 04 - O OLHAR DAS MULHERES ATENDIDAS SOBRE A LEI E A JUSTIÇA.

4.1 - AS SUBJETIVIDADES PRESENTES NOS ATENDIMENTOS .

4.2 - O JUIZ E A CONSTRUÇÃO DA PERCEPÇÃO DO ATENDIMENTO PELAS MULHERES 131

4.3 - SOBRE DIFERENTES EXPECTATIVAS E UMA ÚNICA LEGISLAÇÃO . 134

4.4 - SOBRE A DECISÃO DE ARQUIVAR O PROCESSO 142

4.5 - PERCEPÇÕES SOBRE A EFETIVIDADE DAS MEDIDAS PROTETIVAS DE URGÊNCIA 145

CONSIDERAÇÕES FINAIS 147

REFERÊNCIAS BIBLIOGRÁFICAS 152

ANEXO I: 161 


\title{
INTRODUÇÃO
}

\begin{abstract}
"O que de pior pode acontecer conosco é nos resignarmos à ignorância. É preciso aprender a voltar a dizer "não" e a se perguntar por quê, para que e para quem. Se encontrássemos respostas a essas perguntas, talvez melhoraríamos o mundo" (José Saramago, Lancelot, n. 896, 22/09/2000).
\end{abstract}

\section{O contexto do Distrito Federal}

O Distrito Federal (DF) apresenta algumas particularidades em relação à aplicação da Lei Maria da Penha em comparação com as outras unidades da federação. Notícia veiculada no site do Conselho Nacional de Justiça (CNJ), em 10 de março de $2015^{1}$, destaca que "desde a Lei Maria da Penha já foram criados aproximadamente 100 juizados ou varas de violência doméstica em todo o país”. Outra matéria, desta vez veiculada no site do Tribunal de Justiça do Distrito Federal e Territórios (TJDFT), em treze de março de $2015^{2}$, destaca que atualmente o Distrito Federal possui “19 juizados competentes para julgar os processos relacionados aos casos de violência contra a mulher”. De acordo com estes dados é possível inferir que somente no DF estão localizadas cerca de $1 / 5$ dos juizados ou varas de violência doméstica em todo o país.

Sobre as singularidades que o DF possui para atender mulheres em situação de violência doméstica, apresento matéria publicada no jornal "Estado de Minas" em dez de abril de $2013^{3}$. Apesar de a matéria ter sido publicada há mais de dois anos e de nesse período o número de juizados competentes para julgar processos relacionados aos casos de violência contra a mulher do DF ter aumentado consideravelmente, a publicação permanece relevante:

Com 2,6 milhões de habitantes, o DF conta com 10 varas especializadas em proteção à mulher, o maior número do país. $\mathrm{O} \mathrm{CNJ}$ aponta desproporcionalidade na distribuição, já que Minas, com 19,5 milhões de pessoas, tinha até o primeiro semestre do ano passado duas varas.

As particularidades presentes no atendimento oferecido no Distrito Federal também foram citadas no relatório final da Comissão Parlamentar Mista de Inquérito (CPMI),

\footnotetext{
${ }^{1}$ http://www.cnj.jus.br/noticias/cnj/77302-presidente-do-cnj-destaca-na-abertura-da-204-sessao-acoes-decombate-a-violencia-contra-a-mulher ${ }^{2}$ http://www.tjdft.jus.br/institucional/imprensa/noticias/2015/marco/tjdft-encerra-campanha-justica-pela-paz-emcasa-e-apresenta-relatorio-de-atividades ${ }^{3}$ http://www.em.com.br/app/noticia/gerais/2013/04/10/interna_gerais,369540/faltam-varas-especializadas-na-leimaria-da-penha-em-minas-gerais.shtml
} 
publicado em junho de 2013. Este documento tinha como objetivo "investigar a situação da violência contra a mulher no Brasil e apurar denúncias de omissão por parte do poder público com relação à aplicação de instrumentos instituídos em lei para proteger as mulheres em situação de violência”. Sobre o atendimento oferecido no DF, o relatório da CPMI destaca alguns pontos, dentre os quais cito ${ }^{4}$ :

a) A Delegacia da Mulher da cidade de Brasília conta com uma ampla estrutura física, material e adequado número de servidores e pode ser considerada um exemplo de DEAM; b) apenas no Distrito Federal o Instituto Médico Legal (IML) possui uma sala específica para o atendimento a mulheres vítimas de violência sexual, embora o espaço seja pequeno; c) o DF é exemplo sobre a necessidade de um rápido desabrigamento com a consequente diminuição dos fatores de risco às vítimas, o encaminhamento destas ao abrigamento deverá ser comunicado imediatamente ao juiz e ao Ministério Público para que possam apreciar se há elementos para a prisão preventiva, velar pelo rápido processamento do feito e contribuir para o rápido desabrigamento, a exemplo do realizado do Distrito Federal (BRASIL, 2013: 49; 52; 60).

Além destes pontos acima relatados, o Distrito Federal possui desde 2011 a Secretaria de Estado da Mulher do Distrito Federal (SEM/DF) ${ }^{5}$. Castro (2013) informa que dentro desta pasta tem-se a Subsecretaria de Enfrentamento à Violência contra Mulheres, que além de atuar em parcerias com outras instituições, conta com serviços voltados ao tema, como o Disque Direitos Humanos da Mulher, Centro de Referência de Atendimento à Mulher (CRAM), Casa Abrigo e os Núcleos de Atendimento à Famílias e aos Autores de Violência Doméstica (NAFAVD). Castro (2013:29) apresenta outros dados referentes ao contexto presente no Distrito Federal:

\footnotetext{
Na esfera do Sistema de Justiça Criminal várias medidas foram tomadas no sentido de garantir aplicação da Lei Maria da Penha. Além de haver uma delegacia especializada (DEAM), todas as delegacias circunscricionais das regiões administrativas implantaram uma seção de atendimento às mulheres, no intuito de ofertar ao público um atendimento diferenciado nas queixas ligadas à violência de gênero. Promotorias de justiça especializadas nos conflitos da lei 11.340/06 fazem parte da estrutura do Ministério Público local (MPDFT), estando presentes em várias das regiões administrativas.
}

\footnotetext{
${ }^{4} \mathrm{O}$ relatório também aponta os obstáculos que o Distrito Federal precisa superar para garantir o direito das mulheres a uma vida sem violência. Sobre este aspecto, consultar: BRASIL, 2013:307.

${ }^{5}$ Atualmente, existe no Distrito Federal a Secretaria Adjunta de Políticas para as Mulheres, Igualdade Racial e Direitos Humanos (Semidh). Segundo a página oficial http://www.mulher.df.gov.br/sobre-a-secretaria/asecretaria.html, a secretaria elabora e promove políticas voltadas para segmentos historicamente invisibilizados nas políticas públicas - mulheres, populações negra, indígena, cigana e minorias étnicas; pessoas com deficiência, pessoas idosas, pessoas em situação de rua e pessoas LGBTs, visando uma Brasília que saiba conviver, respeitar e incluir.
} 
Dentro desta conjuntura, o Juizado de Violência Doméstica e Familiar contra a Mulher do Fórum do Fórum Hugo Auler, localizado na região administrativa Núcleo Bandeirante destaca-se. Matias (2013) apresenta o denominado "Projeto Piloto Setorial para Proteção Integral à Mulher no Contexto da Violência Doméstica e Familiar no Núcleo Bandeirante", projeto conduzido no referido juizado que fugia do modelo de atendimento observado em outros juizados especializados localizados no Distrito Federal. Segundo a autora (2013:12), “o projeto propõe a criação de um espaço voltado para ouvir as partes e a tentar resolver conflitos subjacentes à violência, por meio da mediação dos 'conflitos cíveis adjacentes ao conflito criminal'".

Outra inovação conduzida por este Juizado ocorreu em 2012. Neste ano foi inaugurado o Centro Judiciário de Solução de Conflitos da Mulher em Situação de Violência Doméstica e Familiar do Distrito Federal (CJM/TJDFT). Segundo a página oficial do projeto ${ }^{6}$, consta como suas atribuições: a) elaboração de levantamento de dados referentes aos procedimentos inerentes à Lei Maria da Penha; b) o assessoramento aos juízes dos Juizados de Violência Doméstica e Familiar contra a Mulher; c) a implantação de mecanismos de avaliação da satisfação dos usuários e de indicativos para aprimoramento dos atendimentos às famílias em contexto de violência doméstica e familiar. Destaco que CJM tem como objetivo "buscar um modelo de atuação judicial que favoreça o pleno atendimento à Lei 11.340/2006”.

Em 2014, foi publicado o "I Plano Distrital de Políticas para Mulheres 2014-2015”, parceria da Secretaria de Estado da Mulher do Distrito Federal ${ }^{7}$ com outras secretarias e organizações da sociedade civil. Este documento destaca que o DF é "a unidade da Federação mais bem equipada para atender as mulheres, conforme conclusão da Comissão Parlamentar Mista de Inquérito (CPMI) do Congresso Nacional” (DISTRITO FEDERAL, 2014:50).

A despeito de todas estas informações, Azevedo et al. (2014:31) argumenta que as características da estrutura judicial não se refletem nos serviços de segurança. Neste sentido, os autores expõem que "o DF conta com apenas uma delegacia especializada de atendimento à mulher, localizada no Plano Piloto de Brasília, e as experiências de articulação em rede dos serviços de referência são ainda incipientes, demandando, portanto, um urgente esforço de diagnóstico" (idem).

\footnotetext{
${ }^{6}$ Para maiores informações consultar a página oficial do CJM/TJDFT: http://www.tjdft.jus.br/institucional/2avice-presidencia/nupecon/centro-judiciario-mulher;http://www.tjdft.jus.br/institucional/2a-vicepresidencia/nupecon/centro-judiciario-mulher/apresentacao;http://www.tjdft.jus.br/institucional/2a-vicepresidencia/nupecon/centro-judiciario-mulher/atividades-do-cjm Último acesso em 10/08/2015.

${ }^{7}$ O Distrito Federal é uma das Unidades da Federação que até 2015 possuía uma secretaria exclusiva de políticas para as mulheres.
} 
Todos estes dados ajudam a apresentar as particularidades presentes no Distrito Federal. De acordo com Azevedo et al. (2014:31) "essa situação faz do Distrito Federal um campo de estudos riquíssimo para compreensão das tensões, limites e potenciais de modelos de atendimento a situações de violência doméstica e familiar no âmbito judicial". É este o contexto no qual a pesquisa que originou esta dissertação se insere. O objetivo deste trabalho é compreender a percepção das minhas interlocutoras sobre o atendimento que elas receberam do sistema de justiça do Distrito Federal ao acionarem a Lei Maria da Penha. No tópico a seguir, detalharei os caminhos desta pesquisa e o objetivo deste trabalho.

\section{Os percursos da pesquisa}

A temática sobre o atendimento oferecido pelo sistema de justiça criminal em casos em que a Lei Maria da Penha é acionada tem me interessado desde 2011. Naquele momento, eu cursava a cadeia de disciplinas necessárias para concluir meu Trabalho de Conclusão de Curso (TCC), com o intuito de obter o grau de bacharela em Ciências Sociais com habilitação em Antropologia. Na época, estava interessada em pesquisar temáticas ligadas à área de gênero, quando fui convidada a participar das reuniões de um grupo de pesquisa cujo objetivo era identificar e analisar práticas em vigor em algumas Varas de Violência Doméstica e Familiar de Brasília e Regiões Administrativas.

Após esse contato, decidi que meu TCC seria sobre a aplicação judicial da Lei Maria da Penha no Distrito Federal. Para a monografia de graduação, tentei construir etnografia sobre um novo tratamento judicial em vigor em um dos Fóruns do Distrito Federal, localizado na Região Administrativa Núcleo Bandeirante. Este Fórum havia implementado um projeto modelo que se caracterizava por ter sido o primeiro no Distrito Federal a contar com uma Equipe de Atendimento Multidisciplinar, destinada a atender pessoas, especialmente mulheres, que passaram por situações de violência doméstica (Andrade Matias, 2013).

Durante a minha pesquisa de campo, embora eu estivesse limitada ao que me propunha a investigar, comecei a pensar sobre as histórias das mulheres que decidiram judicializar as agressões que sofreram. Em uma quinta-feira de abril de 2012, enquanto assistia aos atendimentos conduzidos pela equipe multidisciplinar, deparei-me com um caso que me chamou bastante atenção.

Uma mulher de aproximadamente 35 anos, dona de casa e mãe de um casal de adolescentes, participava do atendimento com a equipe multidisciplinar, o qual eu observava. Após a equipe multidisciplinar apresentar detalhadamente a Lei Maria da Penha (LMP) e os 
tipos de violência previstos na Lei, ela contou que ao longo das quase duas décadas em que se relacionava com o companheiro, havia sofrido várias agressões. Essas agressões se enquadravam em vários dos tipos de violência descritos na Lei Maria da Penha, mas ela nunca o denunciou.

Alguns dias antes, o marido havia agredido a filha do casal, à época, menor de idade e aquela situação trouxe novos rumos à vida da família. A mãe da garota decidiu levá-la à delegacia para denunciar o ocorrido e, como elas moravam em uma das regiões atendidas pelo Fórum Hugo Auler, foram encaminhadas para a Vara de Violência Doméstica e Familiar Contra Mulheres em que eu fazia trabalho de campo.

As narrativas apresentadas por aquelas duas mulheres, assim como a esperança delas de que o Estado, através da Lei Maria da Penha, iria apontar uma solução definitiva para a situação que elas viviam, impressionou-me. A partir daquele momento, fiquei instigada em saber qual seria o desfecho do caso e, mais ainda, em saber se as grandes expectativas que aquelas mulheres depositavam na Lei Maria da Penha seriam ou não satisfeitas.

Embora a LMP represente um inquestionável avanço político, sobre o qual falarei adiante, em relação à violência doméstica e familiar contra a mulher, com meu Trabalho de Conclusão de Curso comecei a problematizar a eficiência de algumas ações presentes na legislação. Em abril de 2013, já no mestrado, decidi continuar com o tema que havia pesquisado na graduação. Neste sentido, experiência de pesquisa que adquiri no Fórum me instigou a pensar em formas de estar mais próxima das pessoas do que dos processos.

Comecei a buscar bibliografia recente que tivesse sido produzida, preferencialmente, mas não exclusivamente, na antropologia. Embora eu me interesse em compreender situações de violência doméstica e familiar contra mulheres a partir de uma perspectiva multidisciplinar, restringi a busca por referências mapeando a bibliografia recente sobre o tema produzida na área de ciências sociais.

Consultei o "Banco de Teses CAPES"8 e a Biblioteca Digital Brasileira de Teses e Dissertações (BDTD) ${ }^{9}$, páginas que disponibilizam teses e dissertações produzidas em

\footnotetext{
${ }^{8}$ A portaria $\mathrm{n}^{\circ} 013$, de 15 de fevereiro de 2006 instituiu a divulgação digital das teses e dissertações produzidas pelos programas de doutorado e mestrado reconhecidos pelo Ministério da Educação. De acordo com essa portaria, estes programas passaram a ter que disponibilizar obrigatoriamente os arquivos digitais de teses e dissertações defendidas a partir de março de 2006. Segundo a CAPES, "a inclusão de teses e dissertações no Banco de Teses se dá apenas via Coleta de Dados, um aplicativo desenvolvido para coletar informações dos cursos de mestrado, doutorado e mestrado profissional integrantes do Sistema Nacional de Pós-Graduação. As informações são enviadas para a Capes pelas secretarias destes programas". Porém nos sites que consultei, só estavam disponíveis trabalhos cuja data de defesa aconteceu a partir de 2010. Entrei em contato com a CAPES através de e-mail disponibilizado na página e uma das analistas em ciência e tecnologia do órgão respondeu afirmando que a equipe responsável pelo site estava realizando análise dos dados e identificando registros que
} 
programas brasileiros de pós-graduação através de informações enviadas a Capes pelas secretarias destes programas. Em minha busca por trabalhos produzidos na área, utilizei as seguintes palavras-chave: Lei Maria da Penha; Lei 11.340; Violência Doméstica e Familiar Contra Mulheres; Violência Conjugal e Violência de Gênero. Para minha surpresa, nas Ciências Sociais, especialmente na Antropologia, havia poucos trabalhos relacionados ao meu tema de pesquisa.

Ao utilizar os termos mencionados no campo de busca do Banco de Teses CAPES e da BDTD, percebi que a maioria dos trabalhos encontrados pertencia às áreas do Direito, Psicologia, Serviço Social ou a programas de pós-graduação interdisciplinares. Fiquei surpresa por ter encontrado poucos trabalhos pertencentes exclusivamente à área de Ciências Sociais ${ }^{10}$.

A maior parte dos trabalhos produzidos nas Ciências Sociais e em programas de pósgraduação interdisciplinares que encontrei, tinham objetivos bastante diferentes. Encontrei trabalhos que utilizaram pesquisa bibliográfica e documental para conhecer as práticas judiciárias relacionadas à LMP; estudo sobre redes de apoio aos homens autores de violência contra a mulher; pesquisa sobre os significados do trabalho remunerado para mulheres em situação de violência conjugal; estudo sobre o fazer policial nos crimes de violência doméstica e familiar contra a mulher circunscritos na LMP; pesquisa sobre trajetórias de homens que atuaram violentamente contra mulheres em algum momento das suas vidas.; análise de Boletins de Ocorrência de mulheres em situação de violência pertencentes às classe-média e média alta no município de São Paulo; análise dos sentidos do conceito de violência psicológica enunciado no artigo $7^{\circ}$ da LMP, feito através de revisões bibliográficas e de etnografia realizada em espaços institucionais; pesquisa sobre a atuação das práticas dos profissionais que atendem na Delegacia da Mulher de Aracaju; estudos sobre a forma como a Polícia Civil, especialmente a figura do delegado, atua nos casos de violência doméstica contra a mulher; estudos sobre grupos reflexivos de gênero, localizados em dois municípios do estado do Rio de Janeiro; estudo sobre a atuação das organizações não governamentais (ONGs) feministas e dos movimentos de mulheres no âmbito da Lei Maria da Penha; pesquisa em grupos exclusivo de homens autores de violência doméstica no DF; pesquisa sobre

por algum motivo não foram informados de forma completa à época de coleta dos dados. Desta forma, apenas os trabalhos defendidos a partir de 2010 estavam disponíveis.

9 Para acessar estas páginas, basta entrar nos seguintes endereços: http://bancodeteses.capes.gov.br/ e http://bdtd.ibict.br/vufind/. Última consulta realizada em 23/07/15.

${ }^{10}$ Estou me referindo especificamente às áreas de Antropologia, Ciência Política e Sociologia. 
vigilância eletrônica de pessoas em situação de cumprimento de medidas judiciais no âmbito da $\mathrm{LMP}^{11}$.

Durante a minha pesquisa, encontrei a dissertação de mestrado ${ }^{12}$ de autoria de Danielle Cristina Mistretta Vieira César (2014), defendida no Programa de Ciências Sociais da Faculdade de Filosofia e Ciências da Universidade Estadual Paulista. A princípio, supus que o trabalho intitulado "Lei Maria da Penha: Percepções e Vivências" tivesse objetivo muito semelhante a esta dissertação. Entretanto, um aspecto importante no trabalho de César (2014) é que a autora prioriza a percepção de agentes policiais de uma delegacia especializada localizada no interior de São Paulo e, apesar de ter entrevistado mulheres que acionaram a LMP, os objetivos de nossos trabalhos não são os mesmos ${ }^{13}$.

Todos os trabalhos que encontrei na pesquisa bibliográfica e que estão citados acima, em alguma medida, dialogam com minha pesquisa. Afinal, todos pesquisam a Lei Maria da Penha, sua aplicação e/ou consequências. Contudo, nessa busca não encontrei pesquisas que tivessem um recorte semelhante ao que apresento nesta dissertação ${ }^{14}$. Preencher ainda que parcialmente esta lacuna foi um motivo importante para que eu investisse nesse recorte. Mais

\footnotetext{
${ }^{11}$ Os trabalhos que encontrei no banco de teses CAPES e na BDTD e que cito acima foram: ANDRADE, 2012; ALBARRÁN, 2011; ALMEIDA, 2010; ARAUJO,2011; ARAUJO, 2012; BARBOZA 2011, CAPODIFOGLIO, 2012; CARNEIRO, 2012; CARDOZO, 2012; CESAR, 2014; DO CARMO, 2012; CUNHA, 2011; ETAYO,2011; FACHINETTO, 2012; JESUS, 2012; LAKY, 2011; LINS, 2014; MACHADO, 2013; MACIEL, 2014; MONTEIRO, 2014; MOURA, 2011; NUNES, 2011; OLIVEIRA, 2012; PREDEBON JUNIOR, 2014; PERRONE, 2011; PRUDENTE, 2012; SANTOS, 2011; SANTOS, 2012; SARTORI, 2011; SILVA, 2007; SILVA, 2011; SILVA, 2012; SILVA, 2013; SPAGNA, 2012; VAZ, 2012. É importante destacar que a pesquisa cujos resultados estão expostos acima possuem limitações técnicas. Uma delas é que, como disse no texto, no banco de teses CAPES só estão presentes trabalhos realizados entre 2010 e 2012. Nesta direção é importante destacar que nem todas as dissertações e teses mais recentes (defendidas em 2013, 2014 e 2015) estão registradas nos bancos de dados que consultei. Outra limitação é que minha consulta foi realizada através da busca por palavras-chave. Apesar de ter sido muito cuidadosa em minha busca, é possível que haja outros trabalhos sobre o tema, que não foram citados nesta pesquisa porque não consegui localizá-los.

${ }^{12}$ A tese de Gleidismara dos Santos Cardozo (2012), defendida no Programa de Pós-Graduação em Estudos Interdisciplinares Sobre Mulheres, Gêneros e Feminismo da Universidade Federal da Bahia também chamou minha atenção. No resumo consta que a tese "tem por objetivo explorar questões relativas ao fenômeno da violência conjugal contra mulheres das camadas médias do município de Florianópolis" através de vinte entrevistas realizadas com "mulheres das camadas médias urbanas de Florianópolis". Apesar de a tese ter sido defendida em 2012, não consegui localizar a produção em nenhum banco de dados e também não consegui contato com a autora e só encontrei o resumo do trabalho no Bando de Teses CAPES.

${ }^{13}$ No "Capítulo 03 - Vivências da violência doméstica e da Lei Maria da Penha" César (2014:36) apresenta as questões presentes em seu roteiro de entrevistas. Cito: “As questões que orientaram as pesquisas com as mulheres que registraram boletim de ocorrência na DDM foram: seu nome e sua idade? Conte um pouco de sua história de vida, trabalho, filhos, e também sua história com o denunciado? Foi a primeira vez que ele te agrediu? Em sua opinião, porque as mulheres convivem com agressores? Na sua família ou na dele já houve casos de agressão? Você foi bem atendida aqui na DDM? Você conhecia a Lei Maria da Penha antes de estar na DDM? Você acredita que a Lei Maria da Penha está sendo bem divulgada? Você acredita que a Lei Maria da Penha funciona? Por quê? Você pediu medida protetiva? Qual? Demorou a ser atendida em seu pedido de medidas protetivas? Você acredita no fim da violência contra a mulher?".

${ }^{14}$ Destaco que na década de 1990 foram realizadas pesquisas sobre a percepção das pessoas em situação de violência atendidas principalmente pelos JECRIM. Porém, até o momento, existe uma lacuna de pesquisas que falem sobre as usuárias da Lei Maria da Penha após a promulgação da mesma.
} 
do que conhecer o desfecho dos casos, eu estava interessada em procurar maneiras de conhecer aquelas mulheres e suas histórias para além do que eu lia nos processos arquivados.

Interessa-me compreender a percepção das minhas interlocutoras sobre o atendimento que receberam do sistema de justiça ao acionarem a Lei Maria da Penha. Minhas interlocutoras são mulheres cujos processos já estavam encerrados quando eu as conheci. Outro aspecto importante é que elas optaram por arquivar os processos.

Dentro deste contexto de pesquisa, pretendo responder algumas questões: O que elas esperavam quando decidiram procurar o Estado? Quais são os sentidos que essas mulheres atribuem às experiências pelas quais passaram? Elas se sentiram atendidas pelo sistema de justiça? Ocorreram mudanças em suas vidas após a judicialização do caso? Essas foram algumas questões que me guiaram ao longo desta pesquisa.

Este trabalho utiliza a proposta teórica de Roberto Kant de Lima, que destaca o fato de o Estado possuir o conhecimento do conteúdo das normas vigentes e, portanto, a capacidade para a "interpretação correta da aplicação particularizada das prescrições gerais, sempre realizadas através de formas implícitas e de acesso privilegiado" (2008:28). Para Kant de Lima, os processos de representação e mecanismos presentes no direito procuram "enquadrar a realidade" (2008).

Theophilos Rifiotis (2012:305) traz um conceito importante para compreendermos as maneiras como o direito "enquadra a realidade". Este autor utiliza o conceito de “judicialização" para falar sobre o complexo processo que consiste, "fundamentalmente, em interpretar a 'violência conjugal' à luz de uma leitura criminalizante”. Neste aspecto, Rifiotis (idem) reconhece a importância das políticas públicas que lutam contra a impunidade em face da violência contra mulheres serem instrumentos importantes de reconhecimento e acesso à Justiça. Contudo, segundo o autor, a leitura criminalizante apresenta uma série de obstáculos para a compreensão de conflitos interpessoais e sobre a possibilidade de neles intervir.

Ressalta-se que o Judiciário não consegue captar todas as demandas que chegam ao sistema. Neste sentido, Luís Roberto Cardoso de Oliveira argumenta sobre a importância de compreender "os atos ou eventos de desrespeito à cidadania que não são captados adequadamente pelo Judiciário ou pela linguagem dos direitos, no sentido estrito do termo" (2008:137).

O conceito de "insulto moral", utilizado por Cardoso de Oliveira (2010), é importante para compreendermos a dimensão moral dos direitos. $\mathrm{O}$ autor compreende que existem ofensas que nem sempre conseguem ser adequadamente traduzidas em evidencias materiais, logo são frequentemente invisibilizadas no judiciário. Para Cardoso de Oliveira (2010:460), 
trata-se de ofensas que "envolvem sempre uma desvalorização ou mesmo a negação da identidade do interlocutor" (idem).

\section{Organização da dissertação}

No primeiro capítulo desta dissertação, apresento um panorama sobre perspectivas teóricas produzidas no Brasil que se propõe a compreender relacionamentos em que acontecem situações de violência doméstica e familiar contra mulheres. Em seguida, faço breve resumo sobre marcos históricos fundamentais para a promulgação da Lei Maria da Penha. Finalmente, concentro minha análise em conceitos importantes para o debate sobre, reconhecimento, lógicas e limites do sistema de justiça no Brasil.

No segundo capítulo, exploro a minha entrada em campo e conduzo o/a leitor/leitora a trajetória da pesquisa de campo e ao modo como os dados presentes nesta dissertação foram construídos. Apresento a trajetória de pesquisa que percorri ao longo do ano de 2014 para realizar esta pesquisa: os caminhos dentro do Fórum Hugo Auler, o processo de construção da etnografia, o modo como as entrevistas semiestruturadas foi realizado, quem são as mulheres que aceitaram participar desta pesquisa.

No terceiro capítulo, privilegio os relatos que ouvi durante o campo. É aqui que apresento minhas anfitriãs. O foco recai na apresentação e análise da trajetória das minhas anfitriãs quando estas decidiram ir às delegacias (circunscricionais ou especializada no atendimento às mulheres em situação de violência). Nesse ponto, destaco a diversidade presente nestas trajetórias, que se configuraram em diferentes experiências.

No quarto capítulo, retomo as percepções das minhas anfitriãs sobre o atendimento que essas mulheres receberam do sistema de justiça criminal ao acionarem a Lei Maria da Penha. Porém, nesse ponto, em diálogo com as referências teóricas da área de Antropologia do Direito, tento analisar as percepções que elas apresentaram sobre todo o atendimento que receberam do sistema de justiça. Quero compreender se elas se sentiram ou não atendidas por este sistema, se consideram que a Lei Maria da Penha trouxe mudanças para a situação que viviam, se acionariam estes mecanismos novamente. Evidentemente, o Ministério Público, a Defensoria e demais atores e instituições são fundamentais para compreender todo o atendimento oferecido às mulheres em situação de violência, mas neste trabalho destaco que a etnografia é construída a partir das percepções das mulheres sobre o atendimento recebido.

Nas considerações finais retomo as questões inicialmente apresentadas como objetivos do trabalho, articulando-as com o referencial teórico e com os dados de campo. Por último, 
apresento novas questões que surgiram com o campo e que podem ser desenvolvidas em futuras agendas de pesquisa. 


\title{
CAPÍTULO 01 - Sobre violência doméstica e o acesso ao sistema de justiça criminal
}

\begin{abstract}
A justiça é o pão do povo. Às vezes bastante, às vezes pouca. Às vezes de gosto bom, às vezes de gosto ruim. Quando o pão é pouco, há fome. Quando o pão é ruim, há descontentamento (Bertolt Brecht, O pão do povo,1986).
\end{abstract}

Neste capítulo, faço breve resumo sobre o histórico que, de certa forma, culminou na aprovação da Lei 11.340/2006. Inicialmente, recupero importantes perspectivas teóricas produzidas no Brasil sobre relacionamentos em que estão presentes situações de violência doméstica e familiar contra mulheres ${ }^{15}$. Parto do princípio de que as diferentes perspectivas teóricas apresentadas contribuem para a análise dos dados etnográficos que foram construídos com o trabalho de campo que compõe esta dissertação. Por fim, concentro a análise em autores $^{16}$ da área de Antropologia do Direito que trouxeram importantes contribuições para o debate acerca das percepções sobre as lógicas presentes no sistema legal.

\section{1 - Trajetória do conceito de violência doméstica e familiar contra mulheres no contexto brasileiro}

Uma das singularidades que diferenciam o contexto brasileiro do contexto vivido em outros países é que, no Brasil, a articulação entre a defesa pelos direitos das mulheres e os direitos sociais, com foco no direito das mulheres à vida sem violência, sempre foi uma agenda muito presente nos movimentos feministas ${ }^{17}$. Já na década de 1970, importantes obras sobre o tema foram escritas e, a partir da década de 1980, a literatura sobre violência contra as

\footnotetext{
15 Opto por utilizar a expressão "mulheres em situação de violência doméstica e familiar" neste trabalho. Além de esta ser a expressão utilizada pela Lei 11.320/2006, compreendo que essa expressão contribui para reflexão da complexidade presente nas situações de violência doméstica (CAMPOS e CARVALHO, 2011:146). Ressalto que a utilização deste termo não implica, de forma alguma, em eufemismo ou em quaisquer tentativas de "suavizar" as situações pelas quais essas mulheres passaram.

${ }^{16}$ Neste trabalho, opto por não utilizar a flexão de gênero em todos os substantivos que possam sofrer variação. Considero esta opção de escrita eficaz para refletirmos sobre relações e espaços de poder, protagonismo etc... Também considero que esta opção pode auxiliar a pensar sobre a subjetividade a partir do gênero e refletir sobre determinadas lógicas como, por exemplo, o "mito do antropólogo assexuado" pertencente ao gênero masculino (GROSSI, 1992). Entretanto, considero que flexionar gênero para indicar se o substantivo em questão pertence ao masculino ou feminino dificulta a leitura e a torna mais cansativa. Embora nesta dissertação eu tenha optado por adotar a escrita no masculino, peço a/o minha/meu leitora/leitor que considere que eu também estou me referindo ao feminino.

17 Utilizo o plural por compreender a diversidade e multiplicidade presente nos movimentos feministas. Em relação à antropologia feminista, Debert (2010:479) chama atenção para as múltiplas perspectivas presentes. Debert revela que mesmo nas correntes que compõe a chamada feminist legal theory existem argumentações bastante diferentes, especialmente no que concerne ao campo jurídico.
} 
mulheres se constituiu uma das principais áreas temáticas ${ }^{18}$ dos estudos feministas no Brasil. Entre os objetivos das militantes, intelectuais e/ou ativistas feministas daquela época estava fornecer visibilidade à questão da violência doméstica e familiar contra mulheres e combater esse tipo de violência a partir de intervenções sociais, jurídicas ou psicológicas.

A seguir, faço uma breve revisão sobre autoras e suas respectivas obras que trouxeram importantes contribuições empíricas e teóricas para a área de Ciências Sociais, mais especificamente a respeito da violência contra mulheres no contexto brasileiro ${ }^{19}$. Ressalto que estas não foram as únicas obras produzidas sobre o tema, porém elas fornecem instrumentos de análise refinados para refletirmos sobre os dados encontrados em campo. Outro aspecto importante é que os debates sobre violência contra mulheres também contribuíram para políticas conduzidas pelo Estado brasileiro dentro desta temática.

Heleieth Saffioti foi uma importante socióloga brasileira, que se tornou referência nos estudos sobre violência contra mulheres. Ao longo de sua carreira, Saffioti publicou várias obras, dentre as quais destaco "A mulher na sociedade de classes: mito e realidade" (1976) e “O poder do macho" $(1987)^{2021}$.

"A mulher na sociedade de classes" foi publicada, pela primeira vez, em 1969 e é o resultado da tese de livre-docência de Saffioti. Segundo Céli Regina Jardim Pinto (2014:322), Saffioti foi a primeira acadêmica brasileira a escrever um livro cuja análise central era a condição de dominação da mulher. Apesar de o livro conter um estudo sobre a condição da mulher, para Pinto, a análise de Saffioti está centrada nos pressupostos teóricos marxistas que a autora adotava. Desta forma, a obra "A mulher na sociedade de classes" é considerada um estudo marxista sobre o capitalismo subdesenvolvido, no qual as mulheres são vistas como uma prova da distância entre a aparência e a essência nas relações de dominação (PINTO, 2014:323).

\footnotetext{
${ }^{18}$ Destaco, por exemplo: AZEVEDO, M. A. (1985), Mulheres espancadas: a violência denunciada. São Paulo, Cortez; CORRÊA, M. (1981), Os crimes da paixão. São Paulo, Brasiliense; PONTE S, H. A. (1986), Do palco aos bastidores: o SOS-Mulher e as práticas feministas contemporâneas; Campinas, dissertação de mestrado, Campinas, IFCH/Unicamp; ARDAILLON, D. e DEBERT, G. G. (1987) Quando a vítima é mulher, Brasília, Conselho Nacional dos Direitos da Mulher; Saffioti, H. I. B. O Poder do Macho. São Paulo, Moderna, 1987.

${ }^{19}$ Para aprofundar a discussão sobre o conceito de violência nas Ciências Sociais e seus significados sugiro a leitura do artigo "The problem of explaining violence in the social sciences", in P. Gow e P. Harvey (eds.), Sex and violence: issues in representation and experience, Routledge, Nova York 1994.

${ }^{20}$ Saffioti, Heleieth I. B. A Mulher na Sociedade de Classes: Mito e Realidade. Petrópolis, Editora Vozes, 1976. E Saffioti, Heleieth I. B. O Poder do Macho. São Paulo, Moderna, 1987.

${ }^{21}$ Nesta dissertação utilizarei os seguintes critérios gráficos: 1) Em itálico, serão apresentados termos êmicos ou estrangeirismos; 2) Entre aspas aparecerão obras, expressões, conceitos, categorias e frases de outras pessoas (nesses casos, a referência sempre estará indicada); 3) em negrito, palavras ou períodos que considerei importante destacar; 4) entre aspas e em itálico estarão expressões minhas que indicam problematização, coloquialidade, suspeita ou ironia.
} 
A análise construída por Cecília MacDowell Santos e Wânia Pasinato Izumino em "Violência contra as Mulheres e Violência de Gênero: Notas sobre Estudos Feministas no Brasil" (2005) identifica que a teoria produzida por Saffioti corresponderia a corrente teórica $^{22}$ chamada “dominação patriarcal”. Essa corrente, influenciada por perspectivas marxistas, compreende a mulher como sujeito social autônomo que está historicamente vitimada pelo controle social masculino (2005:148).

Logo, merece destaque na produção de Saffioti a concepção de patriarcado presente em sua obra. Essa autora compreende o patriarcado como um sistema de exploração (SANTOS; PASINATO, 2005:150) responsável por fazer com que as mulheres se submetam ao controle e à dominação masculina. Sobre este aspecto, considero oportuno citar o artigo "Contribuições Feministas para o Estudo da Violência de Gênero":

\begin{abstract}
No exercício da função patriarcal, os homens detêm o poder de determinar a conduta das categorias sociais nomeadas, recebendo autorização ou, pelo menos, tolerância da sociedade para punir o que se lhes apresenta como desvio. Ainda que não haja nenhuma tentativa, por parte das vítimas potenciais, de trilhar caminhos diversos do prescrito pelas normas sociais, a execução do projeto de dominação-exploração da categoria social homens exige que sua capacidade de mando seja auxiliada pela violência. Com efeito, a ideologia de gênero é insuficiente para garantir a obediência das vítimas potenciais aos ditames do patriarca, tendo esta necessidade de fazer uso da violência. Nada impede, embora seja inusitado, que uma mulher pratique violência física contra seu marido/companheiro/namorado. As mulheres como categoria social não têm, contudo, um projeto de dominação-exploração dos homens. E isto faz uma gigantesca diferença (...). A ordem patriarcal de gênero, rigorosamente, prescinde mesmo de sua presença física para funcionar. Agentes sociais subalternos, como os criados, asseguram a perfeita operação da bem azeitada máquina patriarcal. Até mesmo a eliminação física de quem comete uma transgressão de gênero pode ser levada a cabo na ausência do patriarca por aqueles que desempenham suas funções. (...) (SAFFIOTI, 2001:115-116)
\end{abstract}

Portanto, Saffioti compreende o patriarcado como sistema de dominação e exploração construído pela ideologia machista, que diz respeito aos campos sociais, políticos, ideológicos, econômicos e que beneficia principalmente o homem rico, branco e adulto (SANTOS; PASINATO, 2005:150). Para Heleieth Saffioti, apesar de a "ordem patriarcal de gênero" 23 não operar sozinha, é esta ordem que "constitui o caldo de cultura no qual tem lugar a violência de gênero, a argamassa que edifica desigualdades várias, inclusive entre homens e mulheres" (SAFFIOTI, 2001:133).

\footnotetext{
${ }^{22}$ Sobre a corrente teórica da "dominação masculina" (PASINATO E SANTOS, 2005:148-151) consultar o artigo de Marilena Chauí "Participando do Debate sobre Mulher e Violência" (1985).

${ }^{23}$ Nesta dissertação utilizarei os seguintes critérios gráficos: 1) Em itálico, serão apresentados termos êmicos ou estrangeirismos; 2) Entre aspas aparecerão obras, expressões, conceitos, categorias e frases de outras pessoas (nesses casos, a referência sempre estará indicada); 3) em negrito, palavras ou períodos que considerei importante destacar; 4) entre aspas e em itálico estarão expressões minhas que indicam problematização, coloquialidade, suspeita ou ironia.
} 
Saffioti argumenta que na "dominação patriarcal" a ideologia machista é responsável por sustentar este sistema, em que mulheres são socializadas para se submeter ao poder patriarcal, enquanto homens são socializados para dominar mulheres. Para Heleieth Saffioti, no exercício da função patriarcal os homens detêm poder para determinar condutas de outras categorias sociais e para punir o que consideram como desvio. Sobre este aspecto, a autora conclui que é através da execução do projeto de dominação-exploração que os homens, enquanto categoria social, utilizam a violência para executar sua capacidade de mando (SAFFIOTI, 2001:115).

Para Saffioti nem sempre o homem precisa estar presente, tendo em vista que "a ordem patriarcal de gênero, rigorosamente, prescinde mesmo de sua presença física para funcionar" (2001:117). De acordo com a autora, para refletir sobre violência contra mulheres é necessário refletir sobre estruturas de poder presentes em nossa sociedade, que perpetuam relações de dominação e subordinação entre os gêneros:

\begin{abstract}
A fim de explicitar melhor o que acaba de ser dito, convém distinguir, de uma parte, a dominação dos homens sobre as mulheres e, de outra, a ideologia que lhe dá legitimidade (...). Para a posição aqui assumida, não se trata meramente de um conjunto mais ou menos sistemático de ideias, mas também, e fundamentalmente, de estruturas de poder. Esta postura tem como premissa a precedência das práticas sobre as ideias. Em outros termos, trata-se da violência enquanto modalidade material de controle social e da repressão exercida através de formas "ideacionais" de socialização. Não se está, com isto, afirmando que a repressão, exercida ao nível das ideias, não contenha violência. Ao contrário, reconhece-se o caráter violento - no plano "ideacional" - do processo de domesticação das mulheres (SAFFIOTI, 1994. p. 445).
\end{abstract}

Embora com ressalvas, assim como Saffioti, compreendo a importância de analisar as relações sociais de poder, muitas vezes assimétricas, que estão presentes em nossa sociedade. Procurar compreender e analisar as relações de poder na vida social também significa perceber, num contexto de investigação que aborda a violência doméstica contra mulheres (e consequentemente, em relacionamentos), que as relações sociais de poder estão presentes nas situações em que há violência doméstica e familiar contra mulheres.

Um aspecto importante presente na obra construída por Heleieth Saffioti é que, ao contrário de outras correntes teóricas que refletem sobre violência contra mulheres, Saffioti (1994) compreende que não se pode falar que há consentimento das mulheres em serem dominadas pelos homens. Isso porque, para a autora, homens e mulheres, enquanto categorias sociais, estão em posições hierárquicas e antagônicas. Para a autora, consentir "presume que coparticipes falem a partir da mesma posição ou de posições iguais" (1994:445). Cito: 
Através da inversão provocada pela ideologia de gênero e de violências factuais nos campos emocional, físico e sexual, a mulher aparece como consentindo com sua subordinação, enquanto categoria social, a uma outra categoria social constituída pelos homens. O problema, portanto, não se põe ao nível do indivíduo, mas de toda uma categoria de gênero. $O$ consentimento não representa senão a aparência do fenômeno, na medida em que a consciência das dominadas é distinta da consciência dos dominantes. (...) Portadoras de uma consciência de dominadas, as mulheres não possuem conhecimento para decidir: elas cedem diante de ameaças ou de violências concretas' (idem).

Santos e Pasinato (2005) construíram um artigo que se propõe a fazer uma revisão crítica da produção teórica sobre violência contra mulheres na área de Ciências Sociais no Brasil. Essas autoras alegam que Saffioti rejeita a ideia de que as mulheres sejam de alguma maneira "cúmplices" da violência a que estão submetidas. Destaco o seguinte trecho:

(...) Embora concebendo-as como "vítimas", a autora as define como "sujeito" dentro de uma relação desigual de poder com os homens. Para Saffioti, as mulheres se submetem à violência não porque "consintam": elas são forçadas a "ceder" porque não têm poder suficiente para consentir (SANTOS; PASINATO, 2005:150).

Essas autoras compreendem que, na perspectiva construída por Saffioti, a “dominação patriarcal" sempre aparece exercida pelo homem sobre a mulher, de forma absoluta e estática. Santos e Pasinato (2005) defendem uma abordagem de violência contra mulheres como uma relação de poder. Para Santos e Pasinato (idem), a noção de dominação patriarcal se mostra insuficiente para compreender as mudanças e os diferentes papéis que mulheres em situação de violência têm e/ou vêm assumindo. Elas compreendem que o poder não é exercido de forma absoluta e estática, sempre pelo homem sobre a mulher, mas exercido tanto por homens quanto por mulheres de forma dinâmica e relacional, ainda que desigualmente (2005:150).

O femicídio é uma categoria de análise que vem ganhando cada vez mais destaque na análise sobre mortes de mulheres no Brasil e na América Latina. Este termo vem sendo utilizado em diferentes trabalhos e, segundo Pasinato (2011:237), a maioria utiliza a formulação proposta pela cientista social sul-africana Diana Russel. Porém, nem sempre o termo utilizado é o mesmo. Neste sentido, Izabel Solyszko Gomes (2010:03) afirma que no Brasil existem divergências quanto à utilização do conceito, que ora aparece como femicídio, ora como femicídio, embora sejam termos com concepções distintas:

O conceito de femicídio utilizado por Almeida (1998) e Saffioti (2004) é diferente de feminicídio proposto por Segato $(2005 ; 2006)$ que, embora concorde com a necessidade de diferenciar os femicídios dos outros tipos de homicídios, afirma que "era necesario demarcar, frente a los medios de comunicación, el universo de los crímenes del patriarcado e introducir en el sen tido común la idea de que hay crímenes cuyo sentido pleno solamente puede ser vislumbrado cuando pensados en 
el contexto del poder patriarcal" (2006, p.4), e propõe a criação de uma tipificação penal para os crimes de feminicídio que considera "o que é escrito no corpo das mulheres brutalmente assassinadas é a assinatura de um poder local e regional que também conta com tentáculos nacionais" (idem, 2005, p.269) (GOMES, 2010:03).

Ainda segundo Gomes, a antropóloga Rita Laura Segato situa análise específica sobre crimes que ocorreram em Ciudad Juarez, no México, e propõe a criação de uma tipificação criminal específica relacionada ao feminicídio (GOMES, 2010:03). Segato (2005:283) afirma que feminicídios não podem ser compreendidos como crimes comuns e, por isso, seria necessário criar novas categorias jurídicas capazes de enquadrá-los e torna-los inteligíveis juridicamente. Sobre este aspecto é oportuno citar:

\begin{abstract}
Afirmo la importância de una tipificación de los diferentes crímenes de mujeres y estoy convencida de que solamente un fuerte énfasis en su diferenciación interna permitirá crear estratégias específicas de investigación policial capaces de llevarnos hasta los perpetradores por caminos más adecuados para cada tipo de caso y generar un cuadro general más acabado de la realidad de los crímenes de género en cada región. Podremos, por ejemplo, tener mayor claridad al abordar aquellas localidades que, como en el caso de la ciudad de Recife, en Brasil, presentan una escalada rápida y desproporcionada en las cifras (SEGATO, 2006:03).
\end{abstract}

Apesar de o uso da categoria feminicídio ainda ser recente no contexto brasileiro, o debate acerca deste termo ganhou destaque com a aprovação da Lei $\mathrm{n}^{\mathbf{0}} 13.104$ de 09 de março de 2015, também conhecida como "Lei do Feminicídio"24. Essa legislação altera o artigo 121 do Código Penal Brasileiro para prever o feminicídio como circunstância qualificadora do crime de homicídio.

Outro importante debate teórico que contribui para nos situarmos na discussão sobre situações de violência doméstica e familiar contra mulheres no contexto brasileiro é a chamada "corrente relacional". A corrente relacional foi desenvolvida principalmente por Maria Filomena Gregori no livro "Cenas e Queixas: um estudo sobre mulheres, relações violentas e a prática feminista" (1993). O livro foi o resultado da dissertação de mestrado em Ciências Sociais de Gregori e trouxe novas perspectivas para o debate que ocorria na época. $\mathrm{O}$ trabalho de Gregori é uma etnografia sobre o atendimento oferecido pelo grupo SOS Mulher na cidade de São Paulo entre 1982 e 1983.

O argumento construído por Gregori em "Cenas e Queixas" (1993) relativiza as noções de dominação masculina versus vitimização feminina e compreende a violência como uma forma de "comunicação" presente na relação. Nessa obra, as mulheres não são

\footnotetext{
${ }^{24}$ Disponível em http://www.planalto.gov.br/ccivil_03/_Ato2015-2018/2015/Lei/L13104.htm. Consultado em
} 21/07/2015. 
compreendidas como "vítimas" da dominação masculina, pois possuem autonomia e participam de "forma ativa" na relação violenta, tornando-se "cúmplices" nessa relação (SANTOS; PASINATO,2005:152), ou seja, Gregori compreende que mulheres tem autonomia e participam das relações violentas.

Gregori entende que, na perspectiva teórica da "dominação patriarcal", a mulher que passa por situações de violência não participa ativamente da construção do seu destino, pois há a transferência desse poder para o homem. Essa autora entende que a "dominação patriarcal" pressupõe que a mulher sempre é vítima, ausente de ação e passiva, enquanto o homem é algoz, dominador (1993:184). Para Gregori, essa é uma percepção dualista que contribui para destituir a mulher de suas subjetividades. Gregori defende que há a "construção da posição da vítima", pois as mulheres entram em relações violentas e acabam "presas" a esse tipo de relacionamento:

\begin{abstract}
De certo modo, ser vítima significa aderir a uma imagem de mulher (...). Estar na posição de vítima, além de permitir o pedido de um auxílio ou proteção externos, reequilibra a relação segundo um recorte em que a mulher se coloca no lugar de alguém que precisa de amparo. Depois da briga física, o marido sai de casa e volta pedindo desculpas, prometendo que vai mudar. Nesse momento, o desempenho masculino e o feminino são confirmados: ele enuncia a promessa de uma modificação na vida familiar (...). É o corpo da mulher que sofre maiores danos, é nela que o medo se instala. E, paradoxalmente, é ela que vai se aprisionar ao criar a sua própria vitimização. O pior não é ser vítima (passiva) diante de um infortúnio; é agir para reiterar uma situação que provoca danos físicos e psicológicos. O difícil para esse tipo de vítima é exatamente o fato de que ela ajuda a criar aquele lugar no qual o prazer, a proteção ou o amparo se realizam desde que se ponha como vítima. Esse é o "buraco negro" da violência contra a mulher: são situações em que a mulher se produz - não é apenas produzida - como não sujeito (GREGORI, 1993:180-184).
\end{abstract}

Essa autora compreende que quando a violência é analisada a partir da perspectiva dualista agressor $x$ vítima, outros aspectos da relação são deixados de lado. As "cenas" que envolvem casais estão sujeitas a diversos fatores como, por exemplo, os conflitos entre condutas esperadas e os papéis de gênero desempenhados por cada um dos parceiros. Gregori defende que é preciso entender os contextos em que a violência ocorre e os diferentes significados que a violência assume. Para essa autora a violência é compreendida como uma forma de comunicação, ainda que perversa, que é vivenciada pelos casais.

Santos e Pasinato (2005) fazem ressalvas à análise conduzida por Gregori ${ }^{25}$. Para as autoras, não é possível compreender o fenômeno da violência como algo que acontece fora de

\footnotetext{
${ }^{25}$ A própria Gregori (2006:261) fez ressalvas a seu trabalho anos após a obra ter sido publicada. A autora argumenta que quando escreveu a dissertação, em 1985, era bastante jovem e acreditava ter encontrado um novo caminho interpretativo ao utilizar perspectivas teóricas de Sade, Bataille, Céline e reconhece uma série de
} 
uma relação de poder. Ao afastar de sua análise quaisquer referências ao poder, Gregori "assume uma igualdade social entre os parceiros" (2005:153). Outra reserva efetuada por Santos e Pasinato (idem) é que Gregori não situa as cenas de violência em um contexto mais amplo e não examina os contextos nos quais ocorreu a violência.

Outra ressalva ao trabalho produzido por Gregori foi realizada por Lia Zanotta Machado e Maria Tereza Bossi de Magalhães no artigo "Violência Conjugal: os Espelhos e as Marcas" (1998). No ponto de vista defendido por Machado e Magalhães, nas relações em que ocorre violência contra mulheres existe diferenciação entre os sujeitos e os não sujeitos de atos de violência física. É oportuno citar:

\begin{abstract}
O enfoque que privilegia a relação afirma que são os dois, cada um a sua maneira, mas sempre os dois que, ao mesmo tempo, são sujeitos e objetos dessas relações afetivas que incluem a violência física (...). Privilegiar a relação não quer dizer que não possamos e não continuemos a entender que para cada ato físico de violência há diferenciação entre os que são sujeitos e os que não são sujeitos de atos de agressão e de violência física e os que são objetos e os que não são objetos de atos específicos. (MACHADO; MAGALHÃES, 1998:25).
\end{abstract}

Machado e Magalhães (2005) defendem que é importante perceber a diferença entre os "sujeitos" e os "não sujeitos" da relação. Para elas, tanto homens quanto mulheres, ainda que diferenciados, são sujeitos das relações em que ocorre violência física, porém "nem sempre sujeitos de atos de violência física" (idem).

Santos e Pasinato (2005), apesar das ressalvas, compreendem que Gregori (1993) trouxe contribuições significativas aos estudos sobre violência contra mulheres. Para Santos e Pasinato (2005), ao investigar o contexto em que ocorreu a violência, Gregori (1993) colocou em destaque a importância de relativizar o modelo "dominação masculina versus vitimização feminina" que estava em vigor. Santos e Pasinato compreendem que "o discurso vitimista não só limita a análise da dinâmica desse tipo de violência como também não oferece uma alternativa para a mulher" (2005:153). O que Gregori evidenciou em sua obra pode nos ajudar a pensar, entre outras coisas, sobre a agência das mulheres que estão em relações violentas e sobre os significados que essas mulheres atribuem às relações em que elas estão e experiências que vivenciaram.

problemas teóricos existentes que só conseguiu enfrentar após uma distância de anos da escrita. Entre estes problemas, Gregori cita o fato de não ter "dissecado a fundo os efeitos da dissimetria de poder numa relação que envolve gênero e violência" (2006:262). Considera também que entre as discussões que requer mais sofisticação está, por exemplo, pensar poder e política de uma forma mais articulada, sem levar a uma despolitização do 


\section{2 - Poder Judiciário, honra e a judicialização das relações}

Outra obra considerada um marco nos estudos referentes ao que hoje é denominado como "violência de gênero" é o livro "Morte em Família" (1983), de autoria de Mariza Corrêa. Essa obra influenciou pesquisadores de diversas gerações e é considerado referência nos estudos que envolvem gênero e direito, especialmente na área da Antropologia. Rifiotis (2014:247), por exemplo, reflete que a obra de Corrêa (1983) destaca o 'silêncio social' e a sua indignação frente ao que se poderia chamar de 'femicídio'. Rifiotis (idem) argumenta que em "Morte em Família", Mariza Corrêa evoca um caso que obteve grande repercussão no Brasil: a morte de Jô Souza Lima, cujo assassino foi absolvido no processo a partir da tese da 'legitima defesa da honra'.

Apesar de ter sido publicado em 1983, "Morte em Família" é fruto de uma dissertação escrita em 1975, como requisito necessário para a aquisição do título de mestra em Ciências Sociais pela autora. A pesquisa que originou a dissertação foi realizada durante o ano de 1974, nos arquivos e varas criminais do Palácio da Justiça da cidade de Campinas. Mariza analisou os dados de casos de homicídio e tentativa de homicídio ocorridos entre casais que foram levados a julgamento no período de 1952 até 1972.

$\mathrm{Na}$ apresentação do livro de Corrêa (1983:11-13), a antropóloga Verena Stolcke afirma que a pesquisa contribui para a reflexão sobre como o Poder Judiciário, à época, legitimava o controle e dominação exercida pelos homens sobre suas mulheres, que socialmente eram construídas como seres inferiores e dependentes. Para Stolcke, “o judiciário contribui de uma forma muito material para a manutenção do sistema de valores dominantes" (CORRÊA, 1983:13) e para a manutenção e perpetuação das desigualdades sociais entre homens e mulheres, à época. Ao refletir sobre a desigualdade com que o Poder Judiciário julgava homens e mulheres, Corrêa (1983) afirma que:

O mito de que todos são iguais perante a lei confronta-se consigo mesmo ao permitir a entrada da realidade concreta, feita de desigualdades, no plano do debate jurídico; Ao estabelecer uma grade de procedimentos formais que dirigem o andamento judicial de um processo, estabelecendo ao mesmo tempo a necessidade de uma rede de relações informais que ponha em marcha esses procedimentos, confrontando cotidianamente os interesses pessoais dos atores jurídicos. Isto faz com que cada processo seja uma tensão permanente ao realizar-se (CORRÊA, 1983:27-28).

campo de atuação (2006:263). Contudo, Gregori explica que é “absolutamente equivocada” a crítica feita a ela de que estaria culpabilizando mulheres que fazem parte de relações violentas. 
Para a autora, embora homens e mulheres estivessem em posições desiguais na sociedade brasileira, quando acusados eles eram submetidos aos mesmos códigos legais. As decisões que surgem da aplicação desses códigos expressam a desigualdade presente nos processos estudados por Corrêa. A autora enfatiza que os atos de transgressão realizados por homens eram vistos como legítimos e havia uma aceitação desses como normais ${ }^{\mathbf{2 6}}$ (CORRÊA, 1983:297). É oportuno citar:

\begin{abstract}
Um processo de homicídio entre casais põe assim a descoberto, em seu movimento, toda uma série de relações sociais que não podem ser perseguidas completamente porque são aí apresentadas de maneira incompleta. As relações reais entre acusados e vítimas como entre os componentes do grupo jurídico não passam para o papel senão de maneira simbólica. No momento em que a morte de uma pessoa pela outra é apresentada como o resultado de uma luta de forças internas, íntimas, domésticas, que podem ser quase reproduzidas no processo e no julgamento - cada um dos debatedores assumindo a parte do acusado e a da vítima - escondem-se, ao mesmo tempo em que se revelam as tensões inerentes a essa relação doméstica, ao tomá-las como ecos de um jogo natural e a-histórico e como equivalentes e homogêneos os motivos que a desencadearam (...). O que os processos estudados revelam em última análise é que sofrem maiores condenações aqueles que são apresentados como os mais inadequados ao modelo de comportamento social implícito nos códigos e explicitado na sua aplicação (CORRÊA, 1983:308).
\end{abstract}

É importante destacar que a pesquisa foi conduzida na década de 1970 e em todos esses anos a sociedade brasileira e, consequentemente, o Poder Judiciário sofreram várias mudanças. Ainda assim, a pesquisa de Corrêa (1983) permanece atual por contribuir com a reflexão sobre a forma como se dá a aplicação dos códigos e legislações. Em vista disso, ajuda-nos a compreender as maneiras como o sistema jurídico se organiza e como as pessoas que são atendidas por esse sistema percebem que suas demandas foram ou não atendidas.

Sobre este aspecto, é oportuno trazer o trabalho de Guita Grin Debert e Maria Filomena Gregori (2008) que, utilizando uma perspectiva foucaultiana de análise, lembram que não é possível compreender dinâmicas presentes nas relações de poder apenas a partir da instância do jurídico. Essas autoras afirmam que é consenso nas Ciências Sociais que "ainda que devamos reconhecer que o jurídico é um campo de disputas, no qual o sistema de direitos é constantemente atualizado, ele se organiza institucionalmente com base em critérios que, ao buscar uma justiça para todos, tende a apagar a dinâmica política que o constitui” (2008:166).

Debert e Gregori (2008) argumentam que os movimentos sociais têm apostado politicamente que um modo privilegiado de combate à violência está na revisão jurídica e nas

\footnotetext{
${ }^{26}$ Corrêa defende que apesar da construção de um modelo de comportamento masculino ou feminino "normal", este modelo não "é perfeito" e, portanto, não está isento de ambiguidades e contradições (1983:297).
} 
instituições do sistema de justiça criminal ${ }^{27}$. Segundo essa perspectiva, nas últimas décadas cresceu a busca pelo Direito para regular aspectos da vida social que antes eram compreendidos como pertencentes exclusivamente ao âmbito doméstico/familiar.

Teophilos Rifiotis analisa o movimento que privilegia e amplia o acesso ao sistema judiciário, mas também desvaloriza outras formas de resolução de conflitos (RIFIOTIS, 2012:31) e denomina este processo de "judicialização"28 das relações sociais. Rifiotis (idem) destaca que nesse processo há a prevalência de soluções locais que estão articuladas em torno da criação de mecanismos de curto prazo, que privilegiam a leitura jurídica dos conflitos interpessoais, a "judicialização".

Segundo Rifiotis (2012:30), é o acesso e recurso aos serviços de polícia e ao sistema judiciário que caracterizam as políticas públicas contra a chamada "violência conjugal" em muitos países. A criação de mecanismos jurídicos acontece com o objetivo de ampliar o acesso ao sistema de justiça a demandas que anteriormente eram entendidas como pertencentes à ordem privada e como tentativa de reduzir a impunidade em relação a estas situações.

$\mathrm{O}$ autor esclarece que não utiliza este conceito com o intuito de questionar a importância dos mecanismos judiciários nos conflitos, mas para "apontar que esse tipo de leitura não pode ser exclusivo, e que a criminalização de tais conflitos é problemática" (2012:32). Sobre este aspecto é oportuno citar:

\begin{abstract}
A judicialização é apresentada como conjunto de práticas e valores, pressupostos em instituições como a Delegacia da Mulher, e que consiste fundamentalmente em interpretar a "violência conjugal" a partir de um ponto de uma leitura criminalizante e estigmatizada contida na polaridade vítima-agressor, ou na figura jurídica do "réu". A leitura criminalizadora apresenta uma série de obstáculos para a compreensão e intervenção nos conflitos interpessoais. Como procuramos mostrar neste trabalho, ela é teoricamente questionável, não corresponde às expectativas das pessoas atendidas nas delegacias da mulher e tampouco ao serviço efetivamente realizado pelas policiais naquela instituição (RIFIOTIS, 2012:32).
\end{abstract}

Debert compreende que a judicialização das relações sociais é uma expressão que busca contemplar a crescente invasão do direito na vida social. Segundo Debert, nas chamadas sociedades ocidentais contemporâneas, a "invasão do direito não se limita à esfera

\footnotetext{
${ }^{27}$ Segundo Ferreira e Fontoura (2008), o sistema de justiça criminal envolve as áreas de ação policial, justiça criminal e execução penal.

28 Compreendo que em outros momentos históricos o poder judiciário interferiu em conflitos e relações interpessoais. Contudo, considero que o conceito proposto por Riffiotis é adequado para refletirmos, entre outros aspectos, sobre o modo como movimentos sociais têm apostado politicamente na revisão jurídica e em instituições do sistema criminal para combater situações de violência (DEBERT,GREGORI:2008) e se o acesso
} 
propriamente política, mas tem alcançado a regulação da sociabilidade e das práticas sociais em esferas tidas, tradicionalmente, como de natureza estritamente privada, como são os casos das relações de gênero" (2010:486).

O Poder Judiciário acolhe cada vez mais "novas demandas". Dessa forma há uma expansão do direito e de suas instituições. Sobre este aspecto, Debert apresenta que alguns analistas compreendem que a expansão do direito e, consequentemente, de suas instituições, seria uma ameaça a cidadania, pois tende a substituir o "ideal de uma democracia de cidadãos ativos" por normas jurídicas. Neste ponto, Debert traz os seguintes argumentos para a discussão acerca das delegacias especiais voltadas para defesa de minorias:

\begin{abstract}
As delegacias especiais de polícia voltadas para a defesa de minorias são, no entanto, fruto de reivindicações de movimentos sociais e, por isso, poderiam ser vistas como expressão de um movimento inverso de politização da justiça. Indicariam antes um avanço da agenda igualitária, porque expressam uma intervenção da esfera política capaz de traduzir em direitos os interesses de grupos sujeitos ao estatuto da dependência pessoal. Por isso mesmo, a criação das delegacias especiais cria uma expectativa de que essas instituições, para além da sua atividade estritamente policial, abririam também um espaço pedagógico para o exercício do que são consideradas virtudes cívicas (DEBERT, 2010:487).
\end{abstract}

Ainda sobre a judicialização das relações, Debert e Gregori (2008:165) argumentam que os movimentos sociais, inclusive os movimentos feministas, têm apostado politicamente na "revisão jurídica e nas instituições do sistema de justiça criminal como modo privilegiado de combate à violência”. Segundo as autoras, nas sociedades contemporâneas, essa expansão do direito não tem se limitado à esfera política, pois vem regulando sociabilidades e práticas sociais. As delegacias de polícia voltadas ao atendimento de minorias sociais são um exemplo dessa expansão, pois é fruto de reivindicações de movimentos sociais.

Debert e Gregori (2008:166) argumentam que este é um exemplo que indica "avanço da agenda igualitária porque expressam uma intervenção da esfera política capaz de traduzir em direitos os interesses de grupos sujeitos ao estatuto da dependência pessoal”. Desta forma, compreendo que o conceito de judicialização pode nos ajudar a analisar o amplo acesso que determinadas demandas, antes quase que exclusivamente entendidas como pertencentes ao âmbito privado, passaram a ser atendidas pelo sistema de justiça criminal.

É importante destacar que essas demandas já existiam anteriormente, mas que o sistema de justiça criminal se tornou mais "sensivel" a determinados setores da sociedade brasileira. Entendo que esta "sensibilidade" foi construída e que a sociedade civil e os

a esses recursos de fato contribui para que as pessoas que procuram essas instituições/sistema se sintam atendidas. 
movimentos sociais foram extremamente importantes para que o Estado brasileiro reconhecesse e criasse mecanismos de atuação específicos para determinadas demandas. Sobre esse aspecto, Lourdes Bandeira (2009:42) lembra que os movimentos feministas foram fundamentais para as mudanças ocorridas no Estado brasileiro:

\footnotetext{
No Brasil, a resistência feminista contra a violência sofrida pelas mulheres acarretou mudanças históricas nos processos legislativos, institucionais e jurídicos. Essas mudanças foram iniciadas no período da ditadura militar, na década de 1970, quando, no cenário das demandas pela anistia política de centenas de homens e mulheres, vítimas da violência militar, segmentos do movimento feminista brasileiro se empenharam em denunciar a violência cometida contra as mulheres no próprio lar. Este processo de resistência se fortaleceu com várias estratégias de luta, dentre elas, a nominação da expressão "violência contra a mulher", seguida pela demanda por políticas públicas a fim de coibi-la.
}

No tópico a seguir, apresento brevemente os processos que alteraram a percepção que predominava no Estado brasileiro, mais especificamente no sistema de justiça criminal, de que a violência doméstica e familiar contra mulheres deveria "ser resolvida" em âmbito privado. Essa percepção compreendia que situações de violência doméstica e familiar contra mulher não deveriam contar com a interferência de agentes externos ao relacionamento e/ou à família.

\section{3 - Os caminhos da criminalização da violência doméstica e familiar contra mulheres no Brasil}

O reconhecimento da violência doméstica e familiar contra mulheres como problema social foi um processo que aconteceu ao longo de décadas e culminou em 2006 com a aprovação de uma legislação específica para combater esse tipo de crime. Segundo Pasinato (2015:533), durante esse processo, a violência contra mulheres se tornou um tema cada vez mais presente nas Ciências Sociais. De acordo com essa autora, os contornos desse campo de estudos nas Ciências Sociais foram bastante influenciados pela interface com as teorias feministas (idem).

Foi um longo caminho para que a Lei 11.360, que criminaliza a violência doméstica e familiar contra mulheres, entrasse em vigor. Sobre esse aspecto, Pasinato afirma que desde a década de 1990 “o movimento de mulheres alertava para a necessidade de leis e políticas especializadas no enfrentamento da violência doméstica e familiar” (2015:533).

Segundo Santos (2008:05), graças à emergência da segunda onda dos movimentos feministas e de mulheres no Brasil na década de 1970, tornou-se possível a politização da 
violência contra mulheres na sociedade brasileira. Santos argumenta que, embora houvesse diferentes interesses e necessidades entre os grupos feministas, a violência doméstica era compreendida como "uma questão comum, atravessando as fronteiras de classe, raça, cor, etnia e ideologia" (idem) e, portanto, questão importante para as militantes dos movimentos feministas. Sobre esse aspecto, é oportuno citar:

\begin{abstract}
Embora a politização da violência contra mulheres não se restringisse à questão da violência doméstica e conjugal, esta passou a ser a forma paradigmática de violência politizada pelos grupos feministas desde o início dos anos 1980 (Santos, 1999a, 1990b, 2005). A violência política contra mulheres foi um dos temas politizados pelas feministas no final da década de 1970, mas logo foi silenciado pela prevalência do discurso sobre violência doméstica. A violência racial contra mulheres negras e a violência contra lésbicas baseada em orientação sexual também foram, e continuam sendo, politizadas por grupos de mulheres negras e de lésbicas (Santos, 2005). Mas o discurso feminista dominante sobre violência fundava-se apenas na "dominação masculina" como o fator estruturante da violência praticada por homens contra mulheres. A substituição das categorias "homem" e "mulher" pela categoria "gênero", adotada pelas feministas desde o início dos anos 1990, não alterou a concepção feminista dominante da violência contra mulheres (SANTOS, 2008:06).
\end{abstract}

Para Santos (2008:03), desde a década de 1980, as feministas "têm lutado por 'serviços integrados' de atenção às mulheres em situação de violência: serviços psicológicos, de assistência social, de saúde e de orientação jurídica; serviços policiais capacitados para esta questão; casas abrigo; e medidas preventivas sobretudo no campo da educação". Segundo a autora, embora essas demandas tenham sido feitas pelas feministas, o Estado tratou essa temática primordialmente como uma questão de polícia. Como exemplo, Santos destaca que:

A primeira delegacia da mulher foi uma proposta do governo do Estado de São Paulo, não do movimento de mulheres. Inicialmente, esta política pública acabou por influenciar a agenda feminista, que passou a priorizar a abordagem da criminalização, embora as feministas também continuassem a desenvolver outras estratégias no campo da psicologia e da saúde pública (SANTOS, 2008:03).

Como explicitado acima, em 1985, houve uma importante resposta institucional do Estado brasileiro a demandas relacionadas à questão da violência doméstica e familiar contra mulheres: a criação da primeira delegacia especializada, cujo atendimento foi totalmente voltado às mulheres. A criação das delegacias especializadas foi um marco para que este tipo de violência começasse a sair do âmbito privado e que as mulheres passassem a ser vistas como pessoas que precisavam de proteção do Estado contra esse tipo específico de violência. Debert e Gregori (2008:166) lembram que as delegacias de polícias voltadas para a defesa das minorias são fruto de uma série de reivindicações de movimentos sociais. Para essas autoras, 
as delegacias especializadas indicam avanços da agenda igualitária e expressam processos de intervenção, que na esfera política traduziram em direitos os interesses desses grupos.

No Brasil, o Estado e as organizações interestatais têm respondido às demandas feministas como, por exemplo, com a criação de delegacias especializadas, através de processo de negociações marcado por absorções mais ou menos restritas dessas demandas (SANTOS, 2008). É o que a autora chama de "absorção seletiva", que implica em uma “'tradução' que necessariamente transforma, visibiliza e silencia determinadas demandas ou aspectos destas demandas"29(2008:02). Ou seja, a autora argumenta que, no Brasil, o Estado selecionou quais as demandas dos movimentos feministas seriam absorvidas e, a partir dessas escolhas, as demandas "absorvidas" passaram por um processo de "tradução" responsável por “transformá-las", trazendo mais visibilidade ou silenciando essas questões.

Debert e Gregori (2008) consideram a importância da criação das Delegacias de Defesa da Mulher (DDM) em 1985, mas advertem que a legislação sobre essas delegacias não fazia menção à violência contra a mulher (2008:168). Segundo as autoras, a cultura jurídica que orientava o trabalho exercido nestes espaços, definia a função da polícia judiciária como o de investigar crimes com base no princípio da legalidade ${ }^{30}$. Abaixo cito trecho do artigo construído por Debert e Gregori (2008) que revela como as DDM funcionavam:

\begin{abstract}
As delegacias atuavam segundo tipificações penais e, como sabemos, violência contra mulher (familiar, doméstica ou de gênero) não constituía figura jurídica, definida pela lei criminal. O que era descrito como tipo penal, implicando uma classificação, dependia, sobretudo, da interpretação que a agente (e, no caso concreto, a delegada ou a escrivã) tinha da queixa enunciada pela vítima. A maior parte dos estudos etnográficos, realizados nos anos de 1980 e 1990, sobre os atendimentos nessas delegacias revela que em função da ausência de uma abordagem sobre a complexidade da dinâmica em que ocorrem os conflitos interpessoais nos quais as vítimas são mulheres, a classificação dos casos tornava-se aleatória ou por demais imiscuída nos repertórios ou representações pessoais das agentes.
\end{abstract}

O trecho acima traz dados, construídos a partir de estudos etnográficos realizados nas décadas de 1980 e 1990, que revelam a importância da percepção das agentes/policias que trabalhavam nas DDMs para a classificação do que seria compreendido como tipo penal. Esse é um aspecto importante, já que para a queixa enunciada pelas mulheres ser levada adiante e ser considerada tipo penal classificável, dependia, sobretudo, da maneira como a agente

\footnotetext{
${ }^{29}$ As palavras em itálico no trecho apresentado estão conforme o trecho original escrito por Santos, 2008.

${ }^{30}$ Segundo Ferreira e Fontoura (2008:08), o princípio básico para o funcionamento do Estado de Direito é o da legalidade. O Estado deve fazer o que a lei determina, enquanto um cidadão só pode ser obrigado ou impedido de fazer alguma coisa em virtude da lei ( $\mathrm{CF}$, art. 5o, inciso II). Portanto, sem uma lei que regule determinado assunto e/ou aspecto da vida social, não há crime.
} 
responsável pelo atendimento compreendia, classificava e interpretava o ocorrido. E a interpretação depende, entre outros fatores, dos sentidos que o receptor atribui à mensagem emitida pelo emissor.

Debert e Gregori (Santos apud Debert e Gregori, 2008:167) afirmam que as agentes reduziam a "noção feminista de violência contra a mulher aos crimes e às infrações cometidos no âmbito da sociedade conjugal em cenário doméstico, excetuando-se, evidentemente, o estupro ou a violência sexual quando cometidos por desconhecidos". Outro aspecto importante apresentado pelas autoras para refletir sobre esse cenário é que denúncias associadas a determinadas formas de violência doméstica e familiar contra mulheres, como violência sexual em relações conjugais, assédio sexual, discriminação sexual, violência psicológica etc., não eram acolhidas adequadamente pelo tratamento institucional oferecido pelo Estado (2008:169).

Avanços significativos ocorreram quando o Brasil, influenciado também pela pressão de movimentos feministas, tornou-se signatário de importantes convenções internacionais, tais como a Convenção de Belém do Pará (1994) e a Conferência de Beijing (1995). De maneira bastante resumida, destaco alguns pontos sobre estes eventos.

A Convenção de Belém do Pará definiu como violência contra a mulher "qualquer ação ou conduta baseada nas diferenças de gênero que cause morte, dano ou sofrimento físico, sexual ou psicológico à mulher, tanto na esfera pública quanto na esfera privada" 31 (CONVENÇÃO INTERAMERICANA, 1994). Esse documento também designou os deveres dos Estados participantes, definiu mecanismos interamericanos de proteção, apontaram direitos a serem respeitados e garantidos. Bandeira (2015:506) recupera que o documento gerado pela Convenção de Belém do Pará se tornou "referência mundial ao enfrentamento à violência contra a mulher", ao ampliar a definição de violência contra mulheres e instituí-la como uma violação aos direitos humanos. Destaco:

Sem dúvida, a Convenção de Belém do Pará significou expressivo avanço em defesa dos direitos humanos das mulheres do continente. Estabeleceu que a violência contra a mulher envolve qualquer ação ou conduta baseada em seu gênero, que lhe cause morte, dano ou sofrimento físico, sexual e psicológico, tanto na esfera privada como pública. Ao mesmo tempo, trata-se de instrumento sociojurídico internacional pioneiro quanto ao problema endêmico da violência contra a mulher, que possibilita que a denúncia interna dos Estados seja deslocada ao plano internacional, como ocorreu com o caso Maria da Penha. Ademais, ampliou a definição de violência baseada na condição de gênero, rompendo com a definição conservadora centrada na violência física, descontextualizada das variadas, tradicionais e interseccionadas

\footnotetext{
${ }^{31}$ Capítulo I (Definição e âmbito de Aplicação), Artigo 1. O documento completo pode ser consultado no site:
} http://www.pge.sp.gov.br/centrodeestudos/bibliotecavirtual/instrumentos/belem.htm. 
relações de poder, em suas transversalidades e com carga altamente nociva ao desenvolvimento democrático. (BANDEIRA, 2015:506)

A IV Conferência das Nações Unidas sobre a Mulher ${ }^{32}$, também conhecida como Conferência de Beijing, foi realizada em setembro de 1995 na China. Bandeira (2015:503) relata que neste evento foram introduzidos novos conceitos referentes às questões de gênero, relacionados à autonomia e equidade das mulheres. A Plataforma de Ação de Pequim foi elaborada nesta ocasião e estabeleceu um conjunto de medidas que deveriam ser seguidas pela comunidade internacional com o intuito de promover a igualdade entre os gêneros e criar políticas que promovessem a capacitação das mulheres. Sobre estes aspectos, cito:

\begin{abstract}
A Plataforma de Ação foi inovadora em três principais dimensões: 1) a elaboração de um conceito de gênero, segundo o qual as relações entre homens e mulheres são vistas como resultado de padrões sociais e culturais, o que permite sua modificação; 2) a noção de empoderamento da mulher, que ressalta a importância da postura feminina ativa sobre seu desenvolvimento, com a participação do governo e da sociedade na criação das condições para que isso ocorra; e, 3) a ideia de transversalidade, que garante que a perspectiva de gênero seja incorporada em todos os temas abrangidos pelas políticas públicas. (BANDEIRA, 2015:503)
\end{abstract}

Dentro de todo esse contexto, foi então se estruturando cada vez mais o enfrentamento à violência doméstica e familiar contra mulheres a partir de uma ótica que privilegia a participação do Estado na resolução desse tipo de conflito. A participação nesse tipo de evento e a assinatura de convenções e tratados realizados em âmbito internacional foram fundamentais para que demandas relacionadas ao fim da violência doméstica e familiar contra mulheres ganhassem destaque no país, em especial em referência ao delineamento de políticas públicas e a criação de legislação específica sobre o tema.

A Convenção de Belém do Pará foi particularmente importante para o contexto brasileiro porque adotou em seu texto o paradigma de que a violência contra a mulher também é um problema público ${ }^{33}$ (BANDEIRA, 2014). Esse documento foi fundamental ${ }^{34}$ para que

\footnotetext{
32 As Conferências organizadas anteriormente foram: I Conferência Mundial sobre a Mulher (Cidade do México, 1975), II Conferência Mundial sobre a Mulher (Copenhague, 1980) e III Conferência Mundial Sobre a Mulher (Nairóbi, 1985). Estes e outros importantes documentos internacionais para a promoção dos direitos das mulheres e da igualdade de gênero podem ser acessados no site http://www.observatoriodegenero.gov.br/eixo/internacional/documentos-internacionais

${ }^{33}$ Capítulo 1, Artigo 2: Entender-se-á que violência contra a mulher inclui violência física, sexual e psicológica: a) que tenha ocorrido dentro da família ou unidade doméstica ou em qualquer outra relação interpessoal, em que o agressor conviva ou haja convivido no mesmo domicílio que a mulher e que compreende, entre outros, estupro, violação, maus-tratos e abuso sexual; b) que tenha ocorrido na comunidade e seja perpetrada por qualquer pessoa e que compreende, entre outros, violação, abuso sexual, tortura, maus tratos de pessoas, tráfico de mulheres, prostituição forçada, sequestro e assédio sexual no lugar de trabalho, bem como em instituições educacionais, estabelecimentos de saúde ou qualquer outro lugar; c) que seja perpetrada ou tolerada pelo Estado ou seus agentes, onde quer que ocorra.
} 
representantes dos movimentos feministas em parceria com a Secretaria de Política para as Mulheres (SPM) propusessem a criação de uma legislação específica para as situações de violência doméstica e familiar contra mulheres (BANDEIRA, 2014:504).

Em meados das décadas de 1990 e 2000 foram criadas legislações que trouxeram para o Estado Brasileiro demandas por justiça e reparação em casos de violência doméstica e familiar contra mulheres. A seguir, falarei sobre a Lei nº 9.099 de 1995 que, embora não tenha sido criada para tratar especificamente sobre a violência doméstica e familiar praticada contra mulheres, foi responsável pela criação dos Juizados Especiais Cíveis e Criminais (JEC e JECRIM). Esse é um aspecto importante da trajetória da criminalização da violência doméstica e familiar no Brasil, pois, com a criação dessa legislação, as denúncias registradas nas delegacias especializadas de atendimento às mulheres passaram a ser tratadas no âmbito dessa lei (BANDEIRA, 2009).

\section{4 - Juizados Especiais Cíveis e Criminais (JEC e JECRIM).}

A Lei dos Juizados Especiais Criminais foi inicialmente pensada como um mecanismo capaz de trazer agilidade aos processos considerados como "de menor potencial ofensivo" (BRASIL, 1995). Inicialmente, o artigo 61 da Lei 9.099/95 $5^{35}$ considerava infrações penais de menor potencial ofensivo, contravenções e crimes cuja pena não ultrapassasse o prazo máximo de um ano, excetuando os casos em que esta mesma Lei previsse procedimentos especiais.

Segundo o Artigo 62 da Lei 9.099/95, essa legislação deveria reparar os danos sofridos pelas vítimas, porém aplicar penas não privativas de liberdade. Outro aspecto importante para que possamos compreender a aplicação dessa lei para situações de violência doméstica é que a Lei 9.099/95 prevê que no Juizado Especial o processo seja orientado por critérios de oralidade, informalidade, economia processual e celeridade.

\footnotetext{
34 A Lei 11.340/2006 utiliza a Convenção de Belém do Pará como referência. Esta Convenção também foi importante para as políticas de enfrentamento à violência contra mulheres quando, em 2001, o Brasil foi condenado na Corte Interamericana de Direitos Humanos (CIDH) após ter sido acusado de ter descumprido tratados internacionais que o país era signatário, entre os quais estava a Convenção de Belém do Pará. A denúncia apresentada por Maria da Penha Fernandes, foi encaminhada em 1998 e alegava a que o Brasil mostrava tolerância com situações de violência contra mulheres (BANDEIRA, 2014). Em http://www.planalto.gov.br/ccivil_03/Projetos/EXPMOTIV/SMP/2004/16.htm é possível consultar o Projeto de Lei que originou a Lei 11.340/206.

35 O texto contendo a publicação original da Lei 9.099/1995 está disponível em http://www2.camara.leg.br/legin/fed/lei/1995/lei-9099-26-setembro-1995-348608-publicacaooriginal-1-pl.html. A legislação também pode ser consultada em http://www.planalto.gov.br/ccivil_03/Leis/L9099.htm
} 
Amorim (2008:04) lembra que a Lei 9.099/95 foi pensada para acolher os delitos que eram previstos no Código Penal cujas penas estipulassem até dois anos de reclusão. Esse é um aspecto muito importante, já que esta lei não foi construída para abrigar ocorrências de violência doméstica contra mulheres. Porém, apesar do insucesso em administrar e reparar situações de violência doméstica contra mulheres, Amorim lembra que a Lei dos JECRIM serviu como porta de acesso ao Judiciário para esse tipo de conflito que, na maior parte dos casos, ficava restrito ao ambiente doméstico ou, no máximo, às delegacias.

De acordo com Azevedo (2001), os Juizados Especiais Criminais abriram as portas da justiça penal para conflitualidades que antes eram resolvidas nas delegacias através de processos informais de resolução de conflitos. Esse era um processo comum, utilizado como um filtro que servia para revelar quais condutas de menor importância - como ameaças e lesões leves no ambiente doméstico, por exemplo - poderiam ou não ingressar no sistema judicial.

Embora não fosse uma legislação específica sobre a violência contra a mulher, a Lei 9.099/96 foi aplicada em um grande número de ocorrências policiais registradas nas Delegacias de Defesa da Mulher (PASINATO, 2004). Em artigo sobre modelos conciliatórios de resolução de conflitos implantados para dar celeridade e ampliar o acesso da população ao judiciário, Marcela Beraldo de Oliveira e Guita Grin Debert (2007) refletem sobre esse modelo, no qual o JECRIM se inseria.

A partir de etnografia conduzida no JECRIM de Campinas (SP), Beraldo de Oliveira e Debert (2007) apresentam várias críticas ao modo como a violência doméstica e familiar contra a mulher era tratada nesses juizados. Segundo essas autoras, as audiências no JECRIM de Campinas duravam cerca de dez minutos e quase sempre a proposta de transação penal era o pagamento de cesta básica para instituições de caridade. Beraldo de Oliveira e Debert relatam que os próprios juízes reconheciam que o pagamento de cesta básica como pena poderia significar banalização da punição da violência doméstica (p. 326).

Para Beraldo de Oliveira e Debert (2007:326), embora as delegacias especializadas trouxessem visibilidade aos crimes praticados contra mulheres, os procedimentos aplicados no JECRIM contribuíam para reprivatizar a violência doméstica. Cito as autoras:

No JECrim, não importa a defesa da mulher enquanto sujeito de direitos, mas a preservação da família e da relação marido e mulher. Dessa forma, essa instituição reifica a hierarquia entre casais de modo a não importunar o trabalho da Justiça. Juízes ou promotores, sensíveis às agressões e ao modo como as mulheres são 
tratadas por seus companheiros, tendem a repreender o acusado, impondo-se uma espécie de função missionária, no sentido de estabelecer as regras que devem orientar o convívio entre marido e mulher (BERALDO DE OLIVEIRA; DEBERT. 2007:328).

Luís Roberto Cardoso de Oliveira (2008) também analisa as críticas à atuação dos JECRIM nos casos em que havia situações de violência doméstica e familiar contra mulheres. $\mathrm{O}$ autor argumenta que as mulheres que procuravam o sistema de justiça criminal não encontravam proteção adequada, tinham suas identidades desvalorizadas, além da forte pressão para que houvesse acordo ou aceitação plena da pena proposta (2008:139). Logo, os acordos, transações penais ou decisões eram focadas apenas no aspecto físico da agressão, sendo que a dimensão moral da agressão, muitas vezes, não era sequer abordada, o que contribuía para inviabilizar a reparação (idem).

Para Pasinato (2004), o acesso que as mulheres tiveram à Justiça com esta legislação foi insuficiente para efetivar direitos à cidadania, mas se constituiu como um acesso ao espaço jurídico que antes se mostrava insensível e ineficiente para com essas demandas. Não obstante, a Lei dos JECRIM significou um avanço, uma vez que ameaças, lesões domésticas e ofensas foram judicializadas, ainda que não tenham sido tratadas com a devida diligência. Sobre esse aspecto, Pasinato (2004) reflete que, a partir do momento em que as mulheres obtiveram espaço para registrar queixas e intervir em situações utilizando dos trâmites legais, passaram a ter a possibilidade de exercer empoderamento nas relações com seus cônjuges consideradas violentas.

\section{5 - A Lei 11.340 de 2006}

Em agosto de 2006, foi promulgada a Lei $n^{\circ} 11.340$, também conhecida como Lei Maria da Penha, que entrou em vigor em setembro de 2006. Essa lei foi criada com o principal objetivo de ser utilizada como um instrumento jurídico que atua na análise e coibição à violência doméstica e familiar contra mulheres, mas também para atuar na prevenção e contribuir para o empoderamento das mulheres que estão em situação de violência.

Pasinato (2010:219) reforça que a legislação em vigor está adequada a diversas convenções internacionais constituídas através de tentativas de coibir a violência contra mulheres, tais como a Convenção de Belém do Pará (1994) e a Convenção sobre a Eliminação de Todas as Formas de Discriminação contra as Mulheres - CEDAW, em inglês- (ONU, 
1979). Além desses documentos, a legislação também está adequada ao que propõe a Constituição Federal do Brasil (1988) que, em seu Artigo $226 \S 8^{\circ}$, prevê que o Estado "assegurará assistência à família na pessoa de cada um dos que a integram criando mecanismos para coibir a violência no âmbito de suas relações".

A Lei configura violência doméstica e familiar contra a mulher, em seu Artigo $5^{\circ}$, como qualquer ação ou omissão contra mulheres que seja baseada no gênero e que cause morte, lesão, sofrimento físico, sexual, psicológico e danos morais e/ou patrimoniais. Sobre esse aspecto, a lei prevê que a situação em que ocorreu a violência possa acontecer no âmbito da unidade doméstica, no âmbito da família, ou em qualquer relação íntima de afeto, "na qual o agressor conviva ou tenha convivido com a ofendida, independentemente de coabitação" (BRASIL, 2006). Outro importante aspecto da Lei é que ela diferencia em cinco as formas de violência doméstica e familiar contra mulheres: violência psicológica, violência física, violência patrimonial, violência sexual e violência moral ${ }^{36} 37$.

Em comparação à Lei dos JECRIM, a Lei 11.340/06 proíbe, nas situações de violência doméstica e familiar contra a mulher, a utilização de penas alternativas, como a doação de cestas básicas e a substituição da pena pelo pagamento isolado de multa. Além disso, a Lei Maria da Penha prevê a prisão do agressor ${ }^{38}$, que pode acontecer em "flagrante delito, preventivamente quando descumprir as ordens de proteção ou em decorrência de decisão condenatória" (PASINATO, 2009:63). Outro ponto que merece destaque é que a Lei 11.340/2006 prevê como pena a detenção de até três anos para a ação violenta praticada contra mulheres, sejam elas cônjuge, ascendente, descendente, irmã ou pessoas com as quais se tenha convívio ou convivido.

\footnotetext{
${ }^{36}$ Art. $7^{\circ}$ : São formas de violência doméstica e familiar contra a mulher, entre outras: I - a violência física, entendida como qualquer conduta que ofenda sua integridade ou saúde corporal; II - a violência psicológica, entendida como qualquer conduta que lhe cause dano emocional e diminuição da auto-estima ou que lhe prejudique e perturbe o pleno desenvolvimento ou que vise degradar ou controlar suas ações, comportamentos, crenças e decisões, mediante ameaça, constrangimento, humilhação, manipulação, isolamento, vigilância constante, perseguição contumaz, insulto, chantagem, ridicularização, exploração e limitação do direito de ir e vir ou qualquer outro meio que lhe cause prejuízo à saúde psicológica e à autodeterminação; III - a violência sexual, entendida como qualquer conduta que a constranja a presenciar, a manter ou a participar de relação sexual não desejada, mediante intimidação, ameaça, coação ou uso da força; que a induza a comercializar ou a utilizar, de qualquer modo, a sua sexualidade, que a impeça de usar qualquer método contraceptivo ou que a force ao matrimônio, à gravidez, ao aborto ou à prostituição, mediante coação, chantagem, suborno ou manipulação; ou que limite ou anule o exercício de seus direitos sexuais e reprodutivos; IV - a violência patrimonial, entendida como qualquer conduta que configure retenção, subtração, destruição parcial ou total de seus objetos, instrumentos de trabalho, documentos pessoais, bens, valores e direitos ou recursos econômicos, incluindo os destinados a satisfazer suas necessidades; V - a violência moral, entendida como qualquer conduta que configure calúnia, difamação ou injúria. Disponível em: http://www.planalto.gov.br/ccivil_03/LEIS/LCP/Lcp150.htm\#art27vii

${ }^{37}$ Para mais informações sobre este aspecto, consultar FEIX (2011).

${ }^{38}$ Agressor é a categoria utilizada na Lei Maria da Penha.
} 
Em sua análise sobre a Lei Maria da Penha, Pasinato compreende que a Lei 11.340/06 está organizada em três eixos de atuação. O primeiro eixo ocupa-se de medidas criminais para que a violência seja punida, tais como "a retomada do inquérito policial, a prisão em flagrante, preventiva ou decorrente de pena condenatória; a restrição da representação criminal para determinados crimes e o veto para a aplicação da lei 9099/95 a qualquer crime que se configure como violência doméstica e familiar contra a mulher” (2010:220). O segundo eixo é dedicado a medidas de proteção da integridade dos direitos da mulher, realizado através de um conjunto de medidas protetivas em caráter de urgência voltadas para promover o afastamento da mulher de quem a agrediu; medidas de assistência que visam fornecer à mulher em situação de violência acesso ao atendimento jurídico, psicológico e social, além de medidas voltadas ao agressor (PASINATO, 2010). O terceiro eixo é voltado para medidas de prevenção e educação, compreendidas como estratégias possíveis e necessárias para coibir a reprodução social da violência e da discriminação baseadas no gênero (PASINATO, 2010:220).

As mudanças advindas com a Lei Maria da Penha representam, absolutamente, importantes avanços em relação à Lei 9.099/95. Porém, a legislação recebeu algumas ressalvas em relação à escolha representada pela leitura criminalizante e pela punição à violência. Pasinato argumenta que, ao definir violência como "um extenso conjunto de práticas, gestos e comportamentos quando estes são direcionados contra as mulheres" (2009:65), a legislação levou a discussão sobre violência baseada no gênero para o campo de intervenção do Direito Penal e da Justiça Criminal.

Dessa maneira, a violência passou a ser classificada como conduta criminosa a partir de categorias que estão presentes no Código Penal Brasileiro. Com isso, empurrou-se a discussão sobre a violência baseada no gênero e sobre a violação de direitos humanos mais para dentro do campo de intervenção do Direito Penal e da Justiça Criminal, o que, segundo a autora (2009), reconduziu ao Estado a tutela da mulher:

Ao fazer este caminho, a lei recolocou o problema da violência contra as mulheres no eixo agressor-vítima e recolocou nas mãos do Estado, através do Judiciário, a tutela da mulher que não pode mais se manifestar nos processos (exceto naqueles em que há necessidade de representação criminal). Estas decisões tem se traduzido em diferentes impactos na forma como a aplicação da legislação vem sendo aplicada nos diferentes estados brasileiros. (PASINATO, 2009:65)

Por sua vez, Azevedo (2008) defende que essa leitura criminalizante dos conflitos de gênero que estão por trás da violência doméstica, "não corresponde às expectativas das 
pessoas atendidas nas delegacias da mulher e tampouco ao serviço efetivamente realizado pelas policiais naquela instituição” (p.131). Para Azevedo, esses processos revelam uma nova relação “entre as instâncias do 'público' e do 'privado"”, apesar de a tutela penal, não necessariamente, promover a resolução dos conflitos, acolher demandas morais e/ou contribuir para a promoção e acesso a sentimentos de justiça das partes envolvidas.

Luna Borges Pereira Santos (2013) aponta que o debate acerca da implementação da Lei Maria da Penha sempre será problemático. A autora argumenta que a Lei 11.340/2006 "se insere na tradição do Civil Law, em que, de acordo com Kant de Lima, direito e lei representam categorias distintas. O que expressa um divórcio possível entre a legislação e o direito, entre a legitimidade do modo de vida jurídico, da elaboração legislativa e da aplicação do direito" (SANTOS, 2013:48).

$\mathrm{Na}$ tentativa de compreender melhor o debate entre antropologia e direito, a seguir me dedico à interlocução entre esses dois campos do saber a partir da perspectiva de autores da área de antropologia do direito. De acordo com Kant de Lima (1995), a tradição de pesquisa presente na antropologia pode contribuir para melhor compreensão do papel e das características do direito. Neste sentido, o autor aponta que o estranhamento familiar é um processo doloroso, especialmente aos não habituados, ou, nas palavras do autor "as pessoas que se movem no terreno das certezas e dos valores absolutos" (p.08). Sobre esse aspecto, o autor aponta:

A própria tradição do saber jurídico no Brasil, dogmático, normativo, formal, codificado e apoiado numa concepção profundamente hierarquizada e elitista da sociedade, refletida numa hierarquia rígida de valores auto demonstráveis, aponta para o caráter extremamente etnocêntrico de sua produção, distribuição, repartição e consumo (KANT DE LIMA, 1995:08).

\section{6 - Antropologia do Direito: reconhecimento, lógica e limites da ação judicial}

Sally Falk Moore (1978) utiliza o conceito de reglementary processes para destacar a complexidade e multiplicidade do direito. Essa antropóloga evidencia que a realidade social é bastante complexa e para estudar as sociedades, seus ordenamentos e regras é necessário apreender as regras explícitas, os contextos em que elas ocorrem e as ideias e suposições que as acompanham $(1978: 2-3)^{39}$.

\footnotetext{
${ }^{39}$ Uma das críticas realizadas a este conceito foi realizada por Cardoso de Oliveira (2010:460), que diz "Além de diferenciar adequadamente as fontes de regulamentação não estatal das leis criadas pelo Estado e sancionadas pelo sistema jurídico oficial, em termos do respectivo poder de implementação das mesmas, a formulação de Moore é suficientemente flexível para permitir a análise das diferentes formas e contextos de controle social
} 
Para Sally Falk Moore (1978:30), quanto mais "racional" uma sociedade parece em seus procedimentos e regras, mais espessa é a camada de formalismo e de ideological selfrepresentation que deverá ser investigada para, de fato, conhecê-la ${ }^{40}$. Sally Falk Moore (1978:03) entende que o controle da vida social por regras possui limitações. Sobre esse aspecto, a autora compreende que as regras não conseguem controlar totalmente a sociedade, pois existem processos sociais que operam fora delas. Além disso, procura entender como as pessoas manipulam, reinterpretam, substituem ou abandonam essas normas.

"O saber local: fatos e leis em uma perspectiva comparativa” (1998) de Clifford Geertz traz reflexões importantes sobre as leis em uma perspectiva comparativa. Geertz afirma que a descrição de um fato que possa ser analisado pelo direito - seja por advogados ou por juízes - é uma representação. Neste sentido, o autor argumenta que a "parte jurídica" do mundo é uma maneira específica de imaginar a realidade. Logo, "trata-se, basicamente, não do que aconteceu, e sim do que acontece aos olhos do direito; e se o direito difere, de um lugar ao outro, de uma época a outra, então o que seus olhos veem também se modifica" (1998:259).

Esse é um aspecto importante do ensaio porque Geertz defende que o direito possui diferentes significados que dependem, por exemplo, do contexto, da época, do local e dos costumes. Ou seja, para Geertz, o direito varia de acordo com as sociedades, com as "culturas", com o "saber local". Por consequência, o direito é saber local. Ao tentar definir melhor este conceito, Geertz afirma que o direito é saber local, contudo compreende que o direito é "local não só com respeito ao lugar, à época, à categoria e variedade de seus temas, mas também com relação a sua nota característica - caracterizações vernáculas do que acontece ligadas a suposições vernáculas sobre o que é possível” (1998: 324-325).

Em artigo que analisa as trajetórias e os desafios da Antropologia do Direito, Schuch (2009) argumenta que Geertz reitera a necessidade de uma visão hermenêutica para pensar o direito como uma maneira de fornecer sentido específico a coisas específicas em lugares específicos (p.62). Nesse artigo, Schuch alega que Geertz, ao defender a investigação das bases culturais do direito, defenderia novos caminhos de investigação para o encontro entre Antropologia e Direito. É oportuno citar:

existentes em qualquer sociedade. Meu único reparo às suas proposições nesta área se refere à pouca importância atribuída por ela às questões de equidade e legitimidade que permeiam quaisquer processos de regulamentação (Cardoso de Oliveira, 1989, pp. 210-239)". 
Defendendo a investigação das bases culturais do direito, a comparação antropológica não se centraria na procura de estruturas comuns aos diversos sistemas de direito, ou na possibilidade de uso de certas categorias legais em diferentes contextos (...), mas se daria no entendimento dos diversos sentidos de justiça, o que chamou de "sensibilidades jurídicas". A tarefa de uma "tradução intercultural" seria possível através de uma espécie de transformação de formas locais de sensibilidade jurídica em comentários recíprocos, de modo a que se realcem mutuamente. Para Geertz, a pluralidade de sensibilidades jurídicas existe e não deixará de existir, sendo uma condição solidificada e não algo transitório ou um desajuste temporário (SCHUCH, 2009:62-63).

É importante ter em vista que, para Geertz, o direito e a etnografia possuem certas semelhanças que os aproximam. Dentre essas semelhanças, o autor destaca que tanto o direito quanto a etnografia "funcionam à luz do saber local (...) e ambos se entregam à tarefa artesanal de descobrir princípios gerais em fatos paroquiais" (GEERTZ, 1998:249). Sobre esse aspecto, é importante entender o que Geertz denomina como "sensibilidades jurídicas" para compreender a perspectiva do direito defendida pelo autor. Para Geertz, "sensibilidades jurídicas" são sentidos de justiça (p.261), definido também como “complexo de caracterizações e suposições, estórias sobre ocorrências reais, apresentadas através de imagens relacionadas a princípios abstratos, que venho dando o nome de sensibilidade jurídica" (1998:325).

São várias as críticas a obra de Geertz, especialmente ao conceito de cultura utilizado por este autor" ${ }^{41}$. Neste trabalho, limitar-me-ei a críticas realizadas ao ensaio "O saber local: fatos e leis em uma perspectiva comparativa" (1998), especialmente ao modo como Geertz reflete sobre o direito. Guita Grin Debert (2010) compreende que a "tranquilidade reflexiva" proposta por Geertz para orientar as pesquisas "só é possível quando examinamos um mundo que nos diz respeito de modo distante, quando o antropólogo pesquisa lugares longínquos e exóticos e quer manter a todo custo esse exotismo" (2010:478).

Debert aponta que na análise geertziana "falta indignação". Para a autora, a indignação pode motivar pesquisas em diferentes instâncias do sistema de justiça e despertar novos interesses, questões e abordagens na antropologia do direito (p.478). Outro aspecto importante da crítica realizada por Debert, é que Geertz propõe uma "abordagem mais desagregante da antropologia e do direito" (p.477), pois na perspectiva defendido por esse autor "o interesse da antropologia do direito não pode ser o de corrigir raciocínios jurídicos através de

\footnotetext{
40 Texto original: The more 'rational' a society seems in its parts, and its rules, and its rules about rules, the thicker the layer of formalism and ideological self-representation to be penetrated to find out what is really going on (MOORE, 1978:30).

${ }^{41}$ Acerca deste debate, consultar Sherry B. Ortner (1999; 2005). Entre as críticas que esta autora faz ao conceito de cultura proposto por Geertz, destaco: "por un lado, el concepto es demasiado indiferenciado, demasiado
} 
descobertas antropológicas" (idem). Debert, opondo-se a essa análise, aponta que estudos conduzidos por cientistas sociais sobre instituições do sistema de justiça no Brasil, indicaram aos profissionais da área do direito "como a ideia de imparcialidade era bombardeada, na prática, por procedimentos tidos como expressão da normalidade e frutos de pura isenção" (idem).

Luís Roberto Cardoso de Oliveira (2010) expõe que a análise conduzida por Geertz utiliza princípios referentes à tradição anglo-americana, conhecida como Common Law. Para Cardoso de Oliveira (2010), ao utilizar essa perspectiva, Geertz "identifica na prática dos juristas ocidentais uma forte preocupação com a elucidação dos fatos, o que não seria bem o caso no contexto do Direito brasileiro" (2010:452).

Outra crítica realizada por Cardoso de Oliveira (2010) é que enquanto Geertz (1998) está preocupado com os pontos de convergência e articulação entre Antropologia e Direito, a sua preocupação está em enfatizar as "implicações das diferenças de perspectiva entre as duas disciplinas ao procurar equacionar estas duas dimensões do real para as quais ambas dirigem seus esforços interpretativos" (p.454). Sobre esse aspecto:

\begin{abstract}
Se no Direito tal articulação se pauta pela necessidade de situar o caso particular no plano de regras ou padrões gerais, externos ao caso, que permitam equacioná-lo de acordo com princípios de imparcialidade, na Antropologia o objetivo seria desvendar o sentido das práticas locais, à luz do ponto de vista nativo, para apreender em que medida a singularidade do caso em tela teria algo a nos dizer sobre o universal. Como argumentei em outro lugar (Cardoso de Oliveira; Grossi \& Ribeiro, no prelo), o que as duas perspectivas disciplinares têm em comum é a critica às interpretações arbitrárias, ainda que em muitas oportunidades as distinções na maneira de fazê-lo provoquem choques interpretativos de difícil superação: a recusa em aceitar a arbitrariedade de uma decisão parcial, no campo do Direito, e a rejeição à arbitrariedade das interpretações etnocêntricas, no campo da Antropologia, nem sempre facilitam o diálogo e viabilizam acordos interpretativos entre as duas disciplinas (idem).
\end{abstract}

Cardoso de Oliveira (2010) aponta uma importante contribuição presente na obra de Geertz que "insiste na importância do antropólogo procurar captar os sensos de justiça embutidos nos procedimentos de administração de conflitos e em suas respectivas sensibilidades jurídicas” (p.465). Análise semelhante também é apontada por Debert, que se aproxima de Cardoso de Oliveira ao apontar a contribuição de Geertz sobre a existência de sensibilidades jurídicas distintas e que essas sensibilidades possuem eficácia na resolução dos conflitos (DEBERT, 2010:478).

homogéneo (...). Por otro, la homogeneidad y falta de diferenciación del concepto de cultura lo vinculaba intimamente al "esencialismo"” (ORTNER, 2005:31). 
Para Roberto Kant de Lima (2001:13), no Brasil ${ }^{42}{ }^{43}$, o sistema jurídico não reivindica uma origem "popular" ou "democrática" e há valorização de conhecimentos não universalizados, disponíveis a poucos na sociedade. Neste contexto, o "capital simbólico" do campo do direito é acessível e internalizado apenas por uma parcela da população. Por conseguinte, o direito é compreendido como produto de uma reflexão iluminada e normativa, cujas regras são pouco acessíveis para maioria da população.

Segundo a análise de Kant de Lima, é o Estado que possui o conhecimento do conteúdo das normas vigentes e, portanto, "competência para a interpretação correta da aplicação particularizada das prescrições gerais, sempre realizadas através de formas implícitas e de acesso privilegiado" (2008:28). Neste sentido, atualmente, ainda são muitos os aspectos dos direitos que normalmente não encontram espaço no judiciário, já que os processos de representação e mecanismos presentes no direito procuram "enquadrar a realidade" (KANT DE LIMA, 2008).

Vem a tempo destacar o conceito de dignidade defendido por Berger (1983). Para esse autor, com o advento da consciência moderna, o conceito de honra se torna obsoleto, o que contribui para a dificuldade em compreender o insulto como um prejuízo real ${ }^{44}$ (BERGER, 1983). Com a sociedade moderna, surge o conceito de dignidade, relacionado ao indivíduo, ao self solitário. Em contraste ao conceito de honra, o conceito moderno de identidade é essencialmente independente dos papéis institucionais ${ }^{45}$ (BERGER, 1983:177).

\footnotetext{
${ }^{42}$ Sobre a análise do discurso jurídico presente no campo do direito no Brasil consultar Kant de Lima (1995).

43 Kant de Lima (1995:58) defende que no Brasil há concomitantemente dois diferentes sistemas éticos disponíveis. Sobre isto: "Este fato é responsável por uma fórmula jurídico político-social também esdrúxula, responsável pela administração de conflitos em nossa sociedade. Refiro-me à convivência de pelo menos dois sistemas racionais de administração de conflitos cujos princípios organizadores são, também, considerados contraditórios: um, da negociação sistemática, o outro, da suspeição sistemática".

${ }^{44}$ Sobre esse aspecto, Berger diz: A obsolescência do conceito de honra aparece nitidamente na incapacidade de muitos contemporâneos em entenderem o insulto, que em essência é um ataque à honra (...). Se alguém é insultado e, como resultado, é prejudicado em sua carreira ou na sua capacidade de obter renda, ele pode entrar com um recurso tendo a compaixão/simpatia de seus amigos. Seus amigos, e em alguns casos, os tribunais, o apoiarão se o insulto o desestabiliza de alguma forma que o faça perder a autoestima ou ter um colapso nervoso. Se nenhum desses danos ocorrer, ele provavelmente será aconselhado por advogados e amigos a esquecer a história. Em outras palavras, a realidade da ofensa será negada (tradução nossa 1983: 172-173).

Texto original: The obsolescence of the concept of honor is revealed very sharply in the inability of most contemporaries to understand insult, which in essence is an assault on honor (...). If an individual is insulted and, as a result, is harmed in his career or his capacity to earn an income, he may not only have recourse to the courts but may count on the sympathy of his friends. His friends, and in some cases the courts, will come to his support if, say, the insult so unsettles him that he loses his self-esteem or has a nervous breakdown. If, however, neither kind of injury pertains, he will almost certainly be advised by lawyers and friends alike to just forget the whole thing. In other words, the reality of the offense will be denied.

45 "The concept of honor implies that identity is essentially, or at least importantly, linked to institutional rules. The modern concept of dignity, by contrast, implies that identity is essentially independent of institutional roles" (BERGER, 1983:177).
} 
Essa percepção trazida por Berger relaciona-se com a análise da dimensão simbólica dos conflitos e dimensão moral dos direitos, proposta por Luís Roberto Cardoso de Oliveira. Cardoso de Oliveira (2010), ao discutir as contribuições da perspectiva antropológica para a análise de conflitos, ressalta a importância da dimensão simbólica dos direitos, "sem a qual demandas por direitos, acordos e decisões judiciais não podem ser adequadamente compreendido" (p.451).

$\mathrm{Na}$ tentativa de compreender "os atos ou eventos de desrespeito à cidadania que não são captados adequadamente pelo Judiciário ou pela linguagem dos direitos, no sentido estrito do termo" (2008:137), Cardoso de Oliveira utiliza o conceito de "insulto moral". Para o autor, existe uma dimensão moral dos direitos que, por se tratar de ofensas que nem sempre conseguem ser adequadamente traduzidas em evidências materiais, são frequentemente invisibilizados no judiciário (2010:460). Trata-se, portanto, de ofensas que "envolvem sempre uma desvalorização ou mesmo a negação da identidade do interlocutor" (idem).

Ao analisar sua experiência etnográfica em diferentes contextos ${ }^{46}$, Cardoso de Oliveira (2008) aponta que o insulto moral (com características e implicações diferentes, a depender do contexto) revelou-se importante para compreender os conflitos presentes nestes cenários. Cardoso de Oliveira defende que insulto moral está frequentemente associado à dimensão dos sentimentos, porém nem sempre os sentimentos e emoções dos atores são adequadamente considerados em procedimentos formais. É relevante citar:

\footnotetext{
O material etnográfico estimulou indagações sobre a expressão ou a evocação dos sentimentos e a mobilização das emoções dos atores na apreensão do significado social dos direitos, cujo exercício demanda uma articulação entre as identidades dos concernidos. Trata-se de direitos acionados em interações que não podem chegar a bom termo por meio de procedimentos estritamente formais e que requerem esforços de elaboração simbólica da parte dos interlocutores para viabilizar o estabelecimento de uma conexão substantiva entre eles, permitindo o exercício dos respectivos direitos (Cardoso de Oliveira, 2004a, pp. 81-93). A atitude de distanciamento ou a ausência de deferência ostensiva situadas no polo oposto desta conexão, quando percebidas como constituindo um ato de desconsideração, provocam o ressentimento ou a indignação do interlocutor, característicos da percepção do insulto (CARDOSO DE OLIVEIRA, 2008:136).
}

Neste sentido, quando a reparação à ofensa aborda outras dimensões que estão relacionadas aos conflitos - como direitos e interesses - existe reparação. Porém, quando não há reparação adequada ao insulto moral, as partes tendem a considerar que o desfecho judicial foi insatisfatório (CARDOSO DE OLIVEIRA, 2010:461). Retomo aqui a citação apresentada no início deste capítulo em que o dramaturgo Bertolt Brecht define a justiça como 
“o pão do povo". Na metáfora presente no poema, Brecht destaca que a justiça é como um alimento, fundamental para a sobrevivência. Assim, o autor ressalta que "Quando o pão é pouco, há fome/Quando o pão é ruim, há descontentamento”.

Daniel Simião (2014:246) em artigo que analisa sensibilidades jurídicas, respeito às diferenças em práticas judiciais no Brasil e em Timor-Leste observa que quando um caso que envolve pessoas em relação de proximidade é judicializando "perde sua natureza original para se tornar, por meio da redução a termos, uma lide judicial". O autor argumenta que este movimento pode excluir do processo judicial, os elementos e sentimentos que deram origem ao conflito.

Segundo Simião, isto pode acontecer porque há uma distancia entre a forma como o Judiciário compreender o caso (a lide) e a maneira como as partes que vivenciaram o conflito enxergam a situação. De acordo com o autor, esta distância entre as partes e o Judiciário tende a gerar entre elas sentimentos de injustiça e desconsideração (idem).

Neste aspecto, Simião entende que a judicialização nem sempre compreende o insulto a partir do ponto de vista das partes. Oportuno citar:

\begin{abstract}
Com isso, parece-me impossível compreender a localização de um ato como insulto ou desconsideração sem levar em conta os complexos jogos de individuação e construção de subjetividades nos quais sujeitos concretos estão inseridos. Os processos de subjetivação (a maneira pela qual um sujeito entende a si mesmo no mundo à sua volta) operantes no local parecem-me cruciais para definir o sentido que os atos podem ganhar para um sujeito. Isso torna também difícil entender o que pode ou não ser percebido como afronta à dignidade de um sujeito em contextos particulares. (SIMIÃO, 2014:249)
\end{abstract}

Bárbara Musumeci Soares lembra que, apesar de ser uma premissa inquestionável a noção de que a violência praticada contra mulheres é um crime, os efeitos "dessa abordagem criminalizante são ainda uma incógnita, já que não existem avaliações capazes de mensurálos” (SOARES, 2012:196). Nesta perspectiva, considero fundamental acessar as percepções das mulheres sobre o processo pelo qual elas passaram quando buscaram o sistema de justiça criminal e acerca do desfecho judicial. Meu objetivo aqui é refletir sobre essas situações e trazer novas questões sobre este tema.

Para conseguir apreender a sensibilidade jurídica ou o senso de justiça, deve ser levada em consideração as pretensões dos atores envolvidos em relação aos procedimentos e encaminhamentos adotados, os desfechos institucionalmente sancionados para os conflitos administrados ou às críticas apresentadas pelos atores ao longo do processo (CARDOSO DE

\footnotetext{
${ }^{46} \mathrm{O}$ autor refere-se a pesquisas realizadas no Brasil, Canadá (Quebéc) e Estados Unidos (Massachusetts).
} 
OLIVEIRA, 2010:466). Nos casos apresentados, as mulheres expuseram uma grande diversidade de percepções acerca dos desfechos finais dos processos. Dessa maneira, veremos que, embora todas tenham sido atendidas por uma mesma legislação, elas acessaram tratamentos bastante diferentes no sistema de justiça criminal. Porém, antes de chegar a esse ponto, veremos no capítulo a seguir como os delicados percursos desta pesquisa moldaram os contornos adquiridos por essa etnografia. 


\title{
CAPÍTULO 02 - Os caminhos da pesquisa e os contornos da etnografia
}

\begin{abstract}
Situar-nos, um negócio enervante que só é bem-sucedido parcialmente, eis no que consiste a pesquisa/etnográfica como experiência pessoal. Tentar formular a base na qual se imagina, sempre excessivamente, estar-se situado: eis no que consiste o texto antropológico como empreendimento científico (Clifford Geertz, A interpretação das Culturas, 1989).
\end{abstract}

Neste trabalho, estou interessada em analisar a perspectiva das mulheres que procuraram o sistema de justiça criminal em situações de violência doméstica. Compreendo que a percepção dessas mulheres constitui uma dimensão de realidade social multifacetada. Esta dissertação foi construída a partir da análise das histórias que essas mulheres escolheram compartilhar comigo nos encontros que tivemos. Essas histórias foram desafiadoras e me fizeram refletir sobre várias questões que vivenciei ao longo do trabalho de campo.

Conduzirei o leitor ao modo como a pesquisa de campo que originou esta dissertação e os dados aqui presentes foram construídos: a trajetória da pesquisa dentro do Juizado de Violência Doméstica e Familiar Contra a Mulher do Núcleo Bandeirante ${ }^{4748}$, a pesquisa nos arquivos do Fórum Desembargador Hugo Auler, as escolhas que fiz para localizar as mulheres, os encontros que originaram as entrevistas.

\section{1 - Mulheres, anfitriãs e interlocutoras}

Ao longo desta dissertação, a exemplo de Borges (2013:200), adotarei principalmente o termo "anfitriãs" para me referir às mulheres que aceitaram participar deste trabalho. Além de terem me recebido em suas casas ou ambientes no qual elas se sentiam seguras para

\footnotetext{
${ }^{47}$ Núcleo Bandeirante é a VIII Região Administrativa (RA) do Distrito Federal. Localizada a 13,3 Km do Plano Piloto, a cidade surgiu em 1956 para abrigar os trabalhadores pioneiros. Atualmente 26 mil pessoas moram na RA, de acordo com dados oficiais. Para mais informações, consultar: http://www.sedhab.df.gov.br/dossieregioes-administrativas.html; $\quad$ http://observatorio.setur.df.gov.br/index.php/brasilia/distrito-federal/; http://www.bandeirante.df.gov.br/sobre-a-ra-viii/conheca-nucleo-bandeirante-ra-viii.html; http://www.anuariododf.com.br/regioes-administrativas/ra-viii-nucleo-bandeirante/. Acessado em 16/07/2015.

${ }^{48}$ Atualmente a Circunscrição Judiciária do Núcleo Bandeirante atende as seguintes Regiões Administrativas: Núcleo Bandeirante (RA VIII), Candangolândia (RA XIX), Park Way (RA XXIV). Contudo, até 2012, essa Circunscrição também atendia o Riacho Fundo I (RA XVII) e Riacho Fundo II (RA XXI). Este é um aspecto importante, porque algumas das minhas anfitriãs foram atendidas Fórum do Núcleo Bandeirante apesar de residirem no Riacho Fundo I e II, pois nessa época a Circunscrição Judiciária do Núcleo Bandeirante atendia essas Regiões Administrativas. Para mais informações, consultar: http://www.tjdft.jus.br/cidadaos/juizadosespeciais/saiba-sobre/circunscricoes-e-regioes-administrativas http://www.tjdft.jus.br/institucional/imprensa/noticias/2012/abril/tjdft-inaugura-forum-do-riacho-fundo Acessado em 16/07/2015.
} 
conversar sobre temas delicados de suas vidas, essas mulheres são anfitriãs porque, de certa forma, concordaram em me receber em suas vidas ao decidirem compartilhar comigo suas histórias. Também utilizo a palavra "interlocutora" para me referir a elas porque compreendo que esse é um termo que pressupõe sujeitos em comunicação e, a meu ver, o processo de construção e acúmulo de saberes que resultou nesta dissertação ocorre a partir da interlocução entre diferentes sujeitos.

Sou extremamente grata a elas por me receberem, por compartilharem comigo a esfera da intimidade, por escolherem dividir segredos. É importante destacar esses pontos porque todo este difícil e complexo processo que vivenciei durante meu trabalho de campo é reflexo do meu envolvimento com a pesquisa e com essas mulheres. O processo de envolvimento e de distanciamento, necessários para a produção de conhecimento antropológico, estão refletidos na configuração escrita e nos propósitos desta dissertação.

É importante ressaltar que os nomes de todas essas mulheres são fictícios. Com o objetivo de preservar a identidade de cada uma delas, substituí os nomes reais por nomes de escritoras da literatura brasileira e estrangeira e/ou personagens da literatura que foram significativas em minha vida. Rachel, Conceição, Carolina, Marina, Alice, Nadine, Clarice, Joana, Hilda, Lygia, Ana Clara, Lia e Lorena são os nomes que representam as mulheres que aceitaram participar desta pesquisa.

Provavelmente, o ideal para com meu leitor seria apresentar detalhadamente as trajetórias de todos os doze processos referentes às interlocutoras que aceitaram participar desta dissertação. Porém, caso eu optasse por apresentar e analisar todos esses dados, este trabalho provavelmente excederia os limites de páginas do que se espera que seja uma dissertação, além de correr o risco de se tornar extremamente maçante. Finalmente, a opção pela forma narrativa que desenvolverei abaixo, vai de acordo com um aspecto ético bastante importante para mim: manter sigilo sobre as identidades das mulheres. Caso eu optasse por esmiuçar as histórias que me foram apresentadas, essas mulheres poderiam ser mais facilmente identificadas neste trabalho.

Compreendo a importância de contextualizar histórias individuais, com o intuito de não isolar minhas interlocutoras dos seus contextos e facilitar a compreensão desta dissertação. Por isso, apresento informações quanto à origem, local de residência e profissões exercidas pelas minhas anfitriãs. Ao mesmo tempo em que procuro não ser extremamente parcimoniosa com informações sobre as minhas anfitriãs, estou preocupada em não ferir a privacidade das minhas interlocutoras. À vista disso, apesar de revelar algumas 
características, procurei ser cuidadosa em relação a outros aspectos com receio de que descrições detalhadas pudessem identificá-las ${ }^{49}$.

Assumo a responsabilidade por ter escolhido não confrontar as falas de diferentes sujeitos sobre uma mesma realidade. Isso seria possível caso eu houvesse conseguido, em minhas diversas tentativas, abertura suficiente para encontra-las mais vezes, ser vizinha de uma delas, enfim, realizar uma observação participante "clássica” junto a essas mulheres. Outra possibilidade seria se a minha proposta fosse entrevistar outras pessoas relacionadas a elas, tais como companheiros e ex-companheiros, amigos, familiares e/ou parentes. Porém, eu não optei por essa escolha porque não considero adequado e ético confrontar falas de pessoas que passaram por situações traumáticas e violentas na busca por "captar as dimensões sociais da emoção" e perceber "discrepâncias entre os discursos e as práticas” (FONSECA, 1999:09).

Compreendo que o fato de não ter conseguido desempenhar tal exercício, transformou este campo em uma escolha arriscada, e que eu, uma antropóloga em formação, poderia "descambar para uma visão simplificada da realidade em que, por exemplo, o informante é visto como sendo falso ou verdadeiro" (FONSECA, 1999:10). Como Fonseca, compreendo que "a abordagem etnográfica exige uma atenção especial a outras linguagens que técnicas de entrevista têm mais dificuldade em alcançar" (idem). Tentei produzir uma etnografia em que relatava em meus diários de campo todo o processo que resultou nesta dissertação e que envolveu encontros e desencontros com minhas anfitriãs e todas as interlocutoras que entrei em contato no processo de produção desta pesquisa.

\section{2 - Sobre negociações e relações estabelecidas em campo}

A dificuldade em fazer uma pesquisa com pessoas que passaram por situações de violência doméstica se deu em muitos aspectos. Se em algumas entrevistas as mulheres mostraram-se muito dispostas a falar, em outras, elas mostraram-se extremamente receosas em abordar o tema. Ao longo do período de campo, percebi que falar sobre violência

\footnotetext{
${ }^{49}$ Nas entrevistas, meu principal objetivo era acessar a percepção dessas mulheres sobre a história que elas viveram. Então, eu me apresentava e pedia para que elas me contassem sobre o que viveram. Como eu havia memorizado o roteiro, conduzia as entrevistas a partir dos fatos que elas me relatavam. Durante as entrevistas, não as questionava sobre a idade, mas esse dado estava disponível nos processos. Um aspecto importante é que não questionei minhas anfitriãs sobre suas características étnico-raciais no momento das entrevistas, o que impediu a autoclassificação. Embora considere que características étnico-raciais são elementos identitários importantes que poderiam trazer para este trabalho novos recortes e possibilidades de análises, eu não havia refletido e decidido sobre essa possibilidade de análise antes de iniciar as entrevistas. Ao longo do campo, concluí que caso eu as tivesse questionado sobre este aspecto (o que provavelmente enriqueceria a análise), eu teria que renunciar a outras características que utilizei, como idade, profissão e local de residência, para assegurar que este trabalho mantivesse o sigilo sobre a identidade das minhas anfitriãs.
} 
doméstica e conjugal contra mulheres envolveu uma variedade de emoções, sentimentos, ações e reações das minhas interlocutoras. Durante as falas das anfitriãs, foi comum haver pausas, voz embargada, silêncios, choro, além de demonstrações de raiva, indignação e descrença na Justiça. No entanto, a realidade que encontrei é complexa e, durante as entrevistas, minhas anfitriãs também demonstravam superação, crença na justiça, alegria e/ou felicidade por terem conseguido transformar uma situação.

Conforme ia vivenciando todas essas ações, reações e sentimentos, aprendi a identificar uma série de momentos. Havia situações em que eu deveria apenas me calar e ouvir com muita atenção o que elas me contavam, permitindo que a interlocutora manifestasse seus sentimentos sobre o que elas haviam sentido e vivenciado. A depender das circunstâncias, era permitido que eu fizesse mais perguntas, me aprofundasse mais e insistisse em determinado assuntos. Em outros momentos, não deveria insistir, mas, ao contrário, redirecionar a entrevista.

Durante a pesquisa, percebi que eram muitos os fatos que, de modo geral, distanciavam-nos e que, em campo, seria preciso negociar várias diferenças: o meu nível de escolaridade, a Universidade em que eu estudava, o fato de eu utilizar as histórias que elas me contavam para produzir conhecimento científico-acadêmico, o fato de eu ser uma mulher mais jovem do que a grande maioria das minhas interlocutoras e, é claro, o fato de eu nunca ter passado pelo processo de judicialização de situações de violência doméstica e familiar. Todavia, compreendi que essas diferenças também nos aproximavam, já que, em vários momentos, elas percebiam que eu não conhecia bem as relações que vivenciaram e, muitas vezes, forneciam detalhes íntimos e importantes, para evitar subtendidos e para que eu conhecesse melhor o ponto de vista delas, sobre o tema ao qual me dedicava.

Contudo, percebi que poderia aproveitar as distâncias e a falta de familiaridade existente entre nós. Procurei "ouvir" minhas anfitriãs, no sentido proposto por Oliveira, em uma busca por criar um espaço semântico em que pudesse ocorrer uma "fusão de horizontes" entre mundos tão diferentes (OLIVEIRA, 2000:24). O fato de eu nunca ter vivenciado experiências semelhantes as que elas me contavam e de demonstrar, em alguns momentos, que não conhecia tão bem as relações familiares na qual elas estavam inseridas e/ou que estabeleceram com o sistema de justiça ao utilizar a Lei Maria da Penha, foi importante para conhecer melhor o ponto de vista dessas mulheres e evitar subentendidos sobre o tema que estava investigando ${ }^{50}$.

\footnotetext{
${ }^{50}$ Sobre evitar subentendidos com os dados de campo, ao final das entrevistas, costumava tirar possíveis dúvidas que houvessem surgido nos nossos encontros. No período em que transcrevi as entrevistas, caso surgisse alguma
} 
A distância também nos aproximou. Era frequente elas perguntarem de onde eu estava vindo, onde eu morava, qual seria o melhor lugar para encontrá-las, pois enfrentávamos situações de deslocamento semelhantes. Essas situações aconteceram, principalmente, com as interlocutoras que trabalhavam fora de suas residências e agendavam as entrevistas após o turno de trabalho, no horário de pico, momento do dia em que as vias de trânsito que saem do Plano Piloto em direção às Regiões Administrativas costumam ficar muito congestionadas. Ouvi, tanto das mulheres que entrevistei quanto das mulheres que, por diversos motivos, desistiram de participar da pesquisa, expressões como "Estou presa por conta do engarrafamento", "Estou saindo do Plano agora, vou atrasar", “O ônibus quebrou, irei demorar".

Embora eu esclarecesse que iria entrevistá-las onde elas agendassem ${ }^{51}$, esse foi um fator que contribuiu para nossa aproximação, pois aumentou a nossa empatia, já que vivenciávamos situações semelhantes pelo fato de não morarmos no Plano Piloto de Brasília $^{52}$. Durante os contatos que antecederam nossos encontros, sempre me dispus a encontrá-las nos locais e horários que elas escolhessem. Compreendo que esse foi um dos motivos que explica o fato de boa parte das entrevistas ter acontecido nas residências dessas mulheres ou nos ambientes de trabalho delas.

Ao longo de todo o meu trabalho de campo, a falta de tempo foi uma justificativa muito utilizada por essas mulheres para adiar as entrevistas. No entanto, nenhuma das minhas anfitriãs quis agendar entrevista para os finais de semana, embora eu tenha sugerido essa possibilidade em alguns momentos. Após a segunda tentativa frustrada de encontrar Lorena, comecei a pensar sobre os motivos que as levavam a nunca agendar comigo nesse período.

Lorena havia marcado a entrevista para às $11 \mathrm{~h}$ de uma sexta-feira. Próximo a esse horário, eu já havia chegado ao Riacho Fundo 2, mas como não estava localizando o endereço que ela havia me fornecido, decidi ligar para pedir mais referências, pois dirigia há bastante

nova dúvida, entrava em contato com as minhas anfitriãs. Por fim, comprometi-me a apresentar este trabalho para minhas interlocutoras, quando ele estivesse escrito.

${ }^{51}$ Embora essas mulheres morassem ou trabalhassem nas regiões administrativas atendidas pelo Fórum Hugo Auler, algumas haviam se mudado desses locais ao longo ou após a judicialização. Por isso, durante o período de campo, nossos encontros aconteceram em diversas regiões do Distrito Federal (DF) e da Área Metropolitana de Brasília (AMB), que compreende além do DF, municípios localizados no Goiás. Para mais informações sobre AMB: $\quad$ http://www.entorno.df.gov.br/sobre-a-secretaria/a-secretaria.html

http://www.codeplan.df.gov.br/noticias/noticias/item/3177-\%C3\%A1rea-metropolitana-de-bras\%C3\%ADliaum-espa\%C3\%A7o-integrado.html. Acessado em 16/07/2015.

52 Utilizo a categoria "Plano Piloto" para me referir às regiões Asa Sul, Asa Norte, Vila Planalto, Vila Telebrasília, Vila Weslian Roriz e Setor Militar Urbano. Essa é a divisão utilizada pela Pesquisa Distrital por Amostra de Domicílios (PDAD), conduzida pelo Governo do Distrito Federal. Para mais informações, consultar:http://www.codeplan.df.gov.br/component/content/article/261-pesquisas-socioeconomicas/295pesquisa-distrital-por-amostra-de-domicilios-.html. Acessado em 16/07/2015. 
tempo pela região. Lorena me disse que era melhor eu voltar outro dia, porque ela precisaria ir mais cedo para o trabalho, já estava se arrumando e não poderia mais conversar comigo. Ela pediu que eu ligasse na semana seguinte para agendarmos um horário e, então, perguntei se não poderíamos nos encontrar no final de semana. Lorena foi bastante incisiva ao negar minha sugestão e respondeu que o marido não gostava de falar sobre esses assuntos e nem que ela falasse sobre esses assuntos. Percebi que o final de semana provavelmente estava reservado para momentos descontraídos que envolviam, sobretudo, família e amigos. Neste aspecto, minha insistência não era bem-vinda, pois poderia estar invadindo um espaço o qual eu não tinha permissão para acessar.

Procurei estabelecer relações de troca com as mulheres que aceitavam participar da pesquisa. Antes do início das entrevistas, sempre explicava que me motivava o fato de, na minha área, existirem poucas pesquisas sobre as percepções que as mulheres que utilizaram a Lei Maria da Penha tiveram do tratamento institucional que elas receberam. Porém, essa descrição se mostrou insuficiente para convencer a maioria das mulheres que contatei a aceitarem participar da pesquisa.

Ao longo do trabalho de campo, percebi a importância de demonstrar que estava disposta a retribuir, através de troca de favores, por exemplo, o tempo e a disposição que elas me ofereciam. A dádiva (MAUSS, 1974) aconteceu de formas distintas com cada uma das minhas anfitriãs. Com Alice e Nadine, por exemplo, pude retribuir oferecendo carona para que elas conseguissem realizar suas atividades em tempo hábil. Já com Lygia, ofereci-me para, caso ela decidisse, acompanhá-la ao Fórum ou à Delegacia.

Outro aspecto importante é que, ao longo do trabalho de campo, escolhi primeiro o meu "terreno" (Fonseca, 1999) para depois entender a representatividade. Ao longo do período em que estive no campo, minhas hipóteses iniciais sofreram grandes transformações, pois eu imaginava que encontraria mulheres que houvessem passado por experiências muito semelhantes ao acionarem a LMP. Ao contrário, percebi que as trajetórias, percepções sobre a justiça e sobre o atendimento que receberam do sistema de justiça são bastante diferentes. A partir das observações que foram feitas, dos dados que construí, das entrevistas que realizei e dos processos aos quais tive acesso abriram-se caminho para as interpretações que serão apresentadas nesta dissertação.

Compreendo que as narrativas apresentadas pelas minhas anfitriãs constituem uma importante e legítima fonte de análise e interpretação antropológica. Os percursos individuais e as experiências vividas quando elas acionaram o sistema de justiça, são fundamentais para essa análise. Nesse aspecto, compartilho a reflexão realizada por Maluf (1999:80) de que "a 
singularidade de cada percurso individual e sua inscrição em um sentido social da experiência permitiu uma compreensão do fenômeno que não teria sido possível a uma abordagem restrita às instituições (...)”.

Assim como afirma Maluf (1999:72), compreendo que as experiências e os sentidos presentes nas falas das minhas anfitriãs não são "redutíveis à narrativa, ao discurso, ou ao texto em seu significado mais largo." Contudo, embora as narrativas apresentadas sejam individuais, também permite refletir sobre experiências sociais dessas pessoas, e sobre a maneira como elas foram construídas. Dessa forma, entendo que a interpretação e a escrita antropológica consistem em um esforço de sistematização do que foi percebido em uma linguagem capaz de dar conta dos significados sociais da experiência (MALUF, 1999:78).

Inicialmente, interessava-me, sobretudo, criar, estabelecer e manter um contato mais próximo com mulheres que passaram por situações de violência em um contexto que preferencialmente estivesse localizado fora do Fórum Hugo Auler. Nos encontros iniciais de orientação dessa pesquisa, eu e meu orientador concordamos que seria interessante entrevistar mulheres e, a partir daí, tentar construir relações mais duradouras com as entrevistadas. A partir desses encontros, eu tentaria, se possível, fazer um estudo de caso com a interlocutora que mostrasse mais afinidade com a pesquisa e comigo, nos moldes do estudo conduzido por Correa (2012). Nesse contexto de pesquisa, uma das propostas iniciais era, inclusive, que eu me mudasse temporariamente para o Núcleo Bandeirante durante o trabalho de campo para me aproximar daquela realidade, ainda que geograficamente.

Certa de que iria estudar esse contexto, comecei a buscar bibliografia recente que tivesse sido produzida, preferencialmente, mas não exclusivamente, por antropólogas/os. Embora eu também esteja interessada em compreender situações de violência doméstica e familiar contra mulheres a partir de uma perspectiva multidisciplinar, achei melhor começar a busca por referências mapeando a bibliografia recente produzida dentro das Ciências Sociais.

Consultei o "Banco de Teses CAPES"53 - página que disponibiliza teses e dissertações produzidas em programas brasileiros de pós-graduação através de informações enviadas a Capes pelas secretarias desses programas. À época da consulta, apenas trabalhos defendidos em 2011 e 2012 estavam disponíveis ${ }^{54}$, pois a página passava por reformulações. Na minha

\footnotetext{
${ }^{53}$ A portaria $n^{\circ}$ 013, de 15 de fevereiro de 2006 instituiu a divulgação digital das teses e dissertações produzidas pelos programas de doutorado e mestrado reconhecidos pelo Ministério da Educação. De acordo com essa portaria, estes programas passaram a ter que disponibilizar obrigatoriamente os arquivos digitais de teses e dissertações defendidas a partir de março de 2006.

${ }^{54}$ Precisava acessar trabalhos realizados sobre este tema a partir de 2006, quando a Lei entrou em vigor. Como neste site só estavam disponíveis trabalhos apresentados em 2011 e 2012, solicitei auxílio à equipe técnica da CAPES, ainda em 2014. Uma Analista em Ciência e Tecnologia da Equipe do Banco de Teses e servidora da
} 
busca, utilizei as seguintes palavras-chave para procurar por trabalhos produzidos na área: Lei Maria da Penha; Lei 11.340; Violência Doméstica e Familiar Contra Mulheres; Violência Conjugal e Violência de Gênero. Para minha surpresa, havia menos trabalhos recentes produzidos nas Ciências Sociais relacionados ao meu tema de pesquisa do que esperava.

Ao utilizar os termos acima mencionados no campo de busca avançada do Banco de Teses CAPES $^{55}$, a maioria dos trabalhos encontrados pertenciam às áreas do Direito, Psicologia, Serviço Social ou a programas de pós-graduação interdisciplinares. Nessa busca, encontrei poucos trabalhos pertencentes, exclusivamente, à área de Ciências Sociais

Embora todos esses trabalhos, em alguma medida, dialoguem com minha pesquisa, ${ }^{56}$ percebi que nenhuma das referências acima continha o mesmo foco que o meu: a percepção das mulheres que judicializaram situações de violência utilizando a Lei Maria da Penha e que, em um momento específico do processo, optaram por arquivar o processo. Ou seja, embora haja uma relação entre os trabalhos, afinal todos utilizam a Lei como tema, nessa busca não encontrei outras pesquisas que tivessem um recorte próximo ao que eu estava construindo. Esse foi um dos motivos, à época em que eu comecei a pesquisa bibliográfica, que me fizeram acreditar e investir nessa pesquisa e a buscar e compreender as histórias dessas mulheres.

Meu ponto de partida para acessar aquelas mulheres continuaria sendo o Juizado de Violência Doméstica e Familiar contra a Mulher do Núcleo Bandeirante. O juiz responsável por aquele Juizado, um dos coordenadores do Centro Judiciário de Solução de Conflitos e Cidadania da Mulher em Situação de Violência Doméstica e Familiar do Distrito Federal (CJM/TJDFT), mostrava-se aberto a propostas de pesquisas de diferentes áreas ${ }^{57}$ - tais como psicologia e antropologia - que dialogassem com o trabalho desenvolvido ali. Dessa forma, eu tinha uma porta de entrada para acessar mulheres que passaram por situações de violência. Em 08 de novembro de 2013, apresentei meu TCC para alguns servidores do Tribunal de

CAPES me enviou um e-mail com um link que fornecia acesso a uma nuvem. Esta nuvem, acessada através de senha, continha dados sobre as pesquisas de mestrado e doutorado defendidas no Brasil no período de 1987 até 2012. Contudo, não consegui acessar esta nuvem por muito tempo e ao entrar novamente em contato com a CAPES em busca dos dados, não obtive resposta. A última tentativa de contato ocorreu em julho de 2015.

${ }^{55}$ Para acessar o Banco de Teses CAPES: http://bancodeteses.capes.gov.br/. Última consulta realizada em $23 / 07 / 15$.

56 Os trabalhos que encontrei no banco de teses CAPES e que cito acima foram: ANDRADE, 2012; ALBARRÁN, 2011; DO CARMO, 2012; OLIVEIRA, 2012; NUNES, 2011; CARNEIRO, 2012; MOURA, 2011; PERRONE, 2011; ETAYO,2011; SILVA, 2012; LAKY, 2011; ARAUJO, 2012; SILVA, 2012; SARTORI, 2011; VAZ, 2012; SILVA, 2011; FACHINETTO, 2012; ARAUJO,2011; JESUS, 2012; SPAGNA, 2012; PRUDENTE, 2012;OLIVEIRA,2012; CARDOZO 2012;

${ }^{57}$ Em um encontro em fevereiro de 2014, por exemplo, o Juiz Titular do Juizado de Violência Doméstica e Familiar contra a Mulher me pediu informações sobre o Núcleo de Estudos e Pesquisa sobre a Mulher (Nepem) da Universidade de Brasília. Relatei ao juiz informações que eu tinha sobre o Núcleo e, a pedido dele, enviei ao seu e-mail uma lista que continha dados sobre a equipe de pesquisadoras ligadas ao Núcleo. Essa lista está disponível na página http://ceam.unb.br/nepem/2.0/?page_id=42 
Justiça do Distrito Federal e Territórios (TJDFT) que compunham a equipe multidisciplinar, para o CJM/TJDFT e o cartório do Juizado e também para o juiz titular e a promotora que atuavam no Juizado de Violência Doméstica e Familiar contra a Mulher do Núcleo Bandeirante.

Após a apresentação, conversei com o juiz sobre a possibilidade de continuar a pesquisa com processos que passaram pelo Juizado de Violência Doméstica e Familiar contra a Mulher do Núcleo Bandeirante, mas que, desta vez, gostaria de ter como interlocutoras as mulheres que judicializaram os casos de violência. Ele ouviu minha proposta e se mostrou favorável a pesquisa e combinamos de, após o recesso das festas de fim de ano, encontrarmonos para que eu lhe apresentasse o meu projeto de pesquisa mais detalhadamente.

Minha proposta inicial era encontrar mulheres cujos casos já tivessem sido encerrados ou arquivados no Fórum, para procurar compreender as percepções dessas mulheres sobre a LMP e o acesso à justiça após o processo ter sido encerrado. O que mais me interessava era entender o ponto de vista das mulheres que alegaram, no registro do Boletim de Ocorrência (BO), terem passado por violência física ${ }^{58}$. Meu principal interesse era conhecer essas mulheres, saber como elas estavam após o processo ter sido encerrado, compreender as percepções delas sobre a LMP e sobre a judicialização após a finalização do processo.

\section{3 - Os percursos e dilemas do campo e os novos caminhos da pesquisa}

Antes de começar a trabalhar com os processos, encontrei-me com o juiz para uma rápida reunião na qual ele me entregou um Termo de Compromisso que havia sido criado para pesquisadores que se interessassem em fazer pesquisa no Fórum. O juiz me explicou que, para

\footnotetext{
${ }^{58} \mathrm{~A}$ Lei 11.340/2006 em seu Capítulo II define as seguintes formas de violência doméstica e familiar contra a mulher: "Art. $7^{\circ}$ São formas de violência doméstica e familiar contra a mulher, entre outras: I - a violência física, entendida como qualquer conduta que ofenda sua integridade ou saúde corporal; II - a violência psicológica, entendida como qualquer conduta que lhe cause dano emocional e diminuição da auto-estima ou que lhe prejudique e perturbe o pleno desenvolvimento ou que vise degradar ou controlar suas ações, comportamentos, crenças e decisões, mediante ameaça, constrangimento, humilhação, manipulação, isolamento, vigilância constante, perseguição contumaz, insulto, chantagem, ridicularização, exploração e limitação do direito de ir e vir ou qualquer outro meio que lhe cause prejuízo à saúde psicológica e à autodeterminação; III - a violência sexual, entendida como qualquer conduta que a constranja a presenciar, a manter ou a participar de relação sexual não desejada, mediante intimidação, ameaça, coação ou uso da força; que a induza a comercializar ou a utilizar, de qualquer modo, a sua sexualidade, que a impeça de usar qualquer método contraceptivo ou que a force ao matrimônio, à gravidez, ao aborto ou à prostituição, mediante coação, chantagem, suborno ou manipulação; ou que limite ou anule o exercício de seus direitos sexuais e reprodutivos; IV - a violência patrimonial, entendida como qualquer conduta que configure retenção, subtração, destruição parcial ou total de seus objetos, instrumentos de trabalho, documentos pessoais, bens, valores e direitos ou recursos econômicos, incluindo os destinados a satisfazer suas necessidades; V - a violência moral, entendida como qualquer conduta que configure calúnia, difamação ou injúria”. Disponível em: http://www.planalto.gov.br/ccivil_03/_ato20042006/2006/lei/111340.htm. Acessado em 16/07/2015.
} 
realizar quaisquer pesquisas no Juizado de Violência Doméstica e Familiar contra a Mulher, seria necessário preencher esse termo. Nesse documento, deveriam constar as seguintes informações: título da pesquisa, número da minha matrícula, número da matrícula do meu orientador, nome do departamento e do instituto ao qual estamos vinculados na Universidade de Brasília. O documento foi assinado por mim, pelo meu orientador e pelo juiz titular responsável do Juizado de Violência Doméstica e Familiar contra a Mulher do Núcleo Bandeirante.

Esse é um documento importante, porque, além de armazenar meus dados e informações sobre a pesquisa que conduzi, é o instrumento que me autorizou a pesquisar no cartório do Juizado de Violência Doméstica e Familiar contra a Mulher, a fazer cópias de processos, inquéritos, medidas protetivas e processos anexos que foram distribuídos de janeiro de 2011 até o prazo inicial, que era dezembro de $2013^{59}$. Portanto, com a assinatura do termo, todas as informações conseguidas através da pesquisa somente poderiam ser utilizadas para a execução da pesquisa e seus desdobramentos, reforçando o compromisso de que nenhum nome ou quaisquer informações que pudessem identificar as partes seriam divulgadas. $\mathrm{O}$ Termo de Compromisso também definia que, ao final da pesquisa, eu deveria destruir todas e quaisquer cópias de processos eventualmente produzidos e utilizados nesta pesquisa.

Na primeira quinzena de janeiro de 2014, voltei a fazer contato com aquela que foi minha principal interlocutora durante a pesquisa que desenvolvi na graduação e que, à época, trabalhava no CJM. Agendei com ela qual seria o melhor dia para que eu fosse ao Fórum pesquisar e consultar os arquivos que me interessavam. Naquele momento, meu objetivo era localizar os processos em que houve denúncias de agressões físicas e que as mulheres tivessem sido atendidas pela equipe multidisciplinar ${ }^{60}$, além de o processo já ter sido arquivado.

A etapa inicial dessa pesquisa aconteceu no Sistema Interno do Tribunal de Justiça do Distrito Federal e Territórios, conhecido pela sigla SISTJ. Para acessar esse Sistema, eu deveria entrar com um login - que corresponde ao número de matrícula dos servidores da Instituição - e com a senha pessoal de um dos servidores. Como as senhas para acessar ao sistema são pessoais e intransferíveis, as minhas primeiras idas ao campo foram mediadas

\footnotetext{
${ }^{59}$ Veremos adiante que, com a pesquisa de campo, percebi que seria mais fácil contatar mulheres cujos arquivos tivessem sido arquivados mais recentemente. Dessa forma, a possibilidade de os dados para contato telefônico continuarem os mesmos era um pouco maior. Por esse motivo, em agosto de 2014 eu pedi autorização para estender a pesquisa para os processos que foram arquivados até 31 de julho de 2014.

${ }^{60} \mathrm{O}$ projeto com a Equipe Multidisciplinar foi inaugurado na Vara de Violência Doméstica do Fórum Hugo Auler em outubro de 2011. Para mais informações, consultar Andrade Matias: 2013; Costa: 2013; Santos: 2013 e Castro:2013.
} 
pelos servidores do TJDFT e pelos momentos que eles dispunham para me auxiliar na busca pelos processos.

Nessa etapa da pesquisa, ao chegar ao Fórum, eu me deslocava direto para o CJM. Embora a servidora que estava me auxiliando nessa empreitada tivesse me instruído a utilizar o SISTJ na busca pelos processos, a presença dela era fundamental, pois recorrentemente o Sistema travava e eu precisava utilizar a senha dela para fazer login novamente e conseguir acessar os arquivos que procurava.

Entre 20 de janeiro e 05 de fevereiro, a servidora agendou comigo outras quatro visitas ao Fórum, em que ela estaria disponível para me ajudar com o SISTJ e com os processos. Durante esses encontros, construímos uma planilha com os números dos processos que compreendiam mulheres requerentes que denunciaram terem sido agredidas fisicamente. Essa planilha continha 34 (trinta e quatro) processos que se encaixavam nas seguintes características: a) A requerente ${ }^{61}$ utilizou a LMP para efetuar denúncias em que houve agressão física; b) As partes do processo passaram pelo atendimento com a equipe multidisciplinar; c) O processo tinha sido encerrado até dezembro de 2013. Essa tabela foi preenchida com diversas variáveis, no entanto considero algumas dessas variáveis como principais: 1) número do processo; 2) número da medida protetiva; 3) data do último andamento; 4) Data da distribuição; 4) nome da requerente; 6) telefone; 7) Resultado final do processo.

Com a tabela em mãos, comecei outra etapa deste trabalho ${ }^{62}$ : a pesquisa nos arquivos do Fórum. Após serem encerrados, os processos percorrem um caminho. Inicialmente, eles ficam por um curto período no cartório de cada um dos Juizados e/ou Varas que estão localizadas no Fórum ${ }^{63}$. Logo após, os processos são classificados e encaminhados para o Arquivo do Fórum. Conforme novos processos chegam ao Fórum, os processos mais antigos são encaminhados para outro arquivo do TJDFT - que está localizado no Setor de Armazenamento Norte em Brasília.

\footnotetext{
${ }^{61}$ Requerente é a pessoa que propôs a ação enquanto que requerido é a pessoa contra quem se propôs a ação. Esses são termos que encontrei na pesquisa de campo e que são utilizados no CJM, no cartório e nos processos (e seus anexos) arquivados para se referir às partes do processo.

62 Devido a circunstâncias familiares, precisei trabalhar durante o meu terceiro semestre como aluna do mestrado. Além do trabalho, estava cursando outras duas disciplinas do PPGAS, que exigiram de mim dedicação a um intenso ritmo de leitura. Dessa forma, tive que pausar a pesquisa durante três meses e meio. Ela foi interrompida entre meados de fevereiro e retomada no mês de junho.

63 Segundo o site: http://www.tjdft.jus.br/institucional/composicao/1a-instancia/nucleo-bandeirante o Fórum Hugo Auler é composto pelos seguintes juizados/varas: Juizado de Violência Doméstica e Familiar contra a Mulher do Núcleo Bandeirante; Juizado Especial Cível e Criminal do Núcleo Bandeirante; Vara Criminal e do Tribunal de Júri do Núcleo Bandeirante; Vara Cível, de Família e de Órfãos e Sucessões do Núcleo Bandeirante. Acessado em 16/07/2015.
} 
Antes de começar esta etapa, eu nunca havia realizado qualquer tipo de pesquisa ou consulta com documentos arquivados em órgãos públicos e sequer sabia a localização do Arquivo do Fórum. O Arquivo do Fórum do Núcleo Bandeirante está localizado no subsolo do Fórum, próximo à lanchonete e ao lado de uma espécie de "garagem interna", onde carros oficiais, veículos pertencentes aos juízes/as e aos promotores/as e os carros de alguns servidores do TJDFT são guardados Na minha primeira ida ao arquivo do Fórum, em 06 de junho de 2014, percebi que aquele era um local com pouco movimento, já que durante toda a tarde em que fiquei coletando dados dos processos, pouquíssimas pessoas apareceram lá. Diferentemente de outros locais do Fórum, o arquivo fica aberto no período das $12 \mathrm{~h}$ até às 18h. A sala do arquivo é pequena e o local é mobiliado com duas mesas - com um computador em cada uma - e três cadeiras que estão localizadas próximas à porta. Além essa mobília e de um bebedouro com galão, a sala é ocupada por várias estantes enormes que são preenchidas com processos de todas as Varas e/ou Juizados localizados no Fórum.

Para poder consultar os processos que estavam na planilha construída no início do ano, precisei apresentar documentos de identificação e deixar uma cópia do Termo de Autorização no Arquivo. Para minha surpresa, não consegui acessar a grande maioria dos trinta e quatro processos que estavam na planilha, porque eram processos que estavam arquivados em caixas consideradas antigas pela classificação do Arquivo e do Fórum e, por esse motivo, haviam sido encaminhados ao Arquivo Central, local que eu não tinha autorização para pesquisar ${ }^{64}$.

Dos 34 processos cujos dados compunham a minha planilha, só consegui ter acesso a 11 processos que ainda estavam arquivados no Fórum e, após localizar esses processos, comecei a produzir informações sobre eles. Inicialmente, levava meu caderno de campo para anotar as informações que julgava essenciais do processo e produzia uma espécie de resumo de cada um dos documentos. No entanto, percebi que esta metodologia não era eficiente, pois, para conseguir ler, resumir e anotar os principais dados de um processo, gastava muito tempo. Para se ter uma ideia, nas minhas primeiras idas ao Arquivo, consegui resumir, em média, dois processos por tarde, a depender da quantidade de volumes que compunha o processo.

Após quatro dias visitando o Arquivo e conseguindo dados de apenas sete processos, acatei a sugestão da estagiária e dos servidores e comecei a fotografar os processos. Embora esse também fosse um processo lento, já que alguns processos eram muito grandes e/ou tinham mais de um volume, era uma técnica muito mais produtiva e consideravelmente menos

\footnotetext{
${ }^{64} \mathrm{O}$ Termo de Compromisso que eu havia assinado só me permitia acessar os processos que haviam passado pelo Juizado de Violência Doméstica e Familiar contra a Mulher do Núcleo Bandeirante e que ainda se encontrassem
} 
cansativa e desgastante. Além do mais, o Termo de Compromisso permitia que eu produzisse dados a partir dos processos consultados utilizando, para isso, técnicas que eu considerasse melhor. A principal condição do Termo de Compromisso era que, após utilizar os dados na pesquisa, descartasse todo o material que foi produzido. Esse período de visitas ao arquivo aconteceu ao longo do mês de junho ${ }^{65}$. Com mais alguns dias de trabalho, consegui fotografar todos os 11 processos que estavam localizados no arquivo do Fórum.

Após classificar e organizar os dados dos processos em pastas no meu computador, comecei a agendar entrevistas. Para realizar as entrevistas, decidi que seria necessário ter em mãos um roteiro aberto de perguntas que me ajudasse a conduzir os encontros com as mulheres. A versão final do roteiro que utilizei ${ }^{66}$ ficou com trinta e seis perguntas que foram alocadas em cinco blocos com temáticas que, embora diferentes, estavam interligadas.

No primeiro bloco temático, as questões eram sobre o relacionamento que elas tinham vivenciado: como se conheceram; como a relação começou; por quanto tempo ficaram ou se estavam juntos; como começou as situações de violência; a frequência dessas situações etc.

No segundo bloco, estavam as questões relacionadas à decisão de recorrer à Lei Maria da Penha, tais como: em que momento elas decidiram procurar a delegacia; o que as motivou a prestar ocorrência; como foi o atendimento na delegacia; se elas foram à delegacia mais de uma vez; quais mudanças ocorreram em suas vidas após a ida à delegacia, entre outras ${ }^{67}$.

No terceiro bloco temático, eu apresentava questões sobre o atendimento que elas receberam no Fórum: como foi o atendimento recebido no Fórum e o atendimento com a equipe multidisciplinar; se demorou entre a data em que foram à delegacia até a data em que foram chamadas ao Fórum; se tiveram acesso à defensoria ou à alguma/algum advogada/o; se

naquele Fórum. Para ter acesso aos processos que estavam no Arquivo Central, eu deveria conseguir permissão de outras autoridades do TJDFT.

${ }^{65}$ Embora eu não estivesse mais trabalhando, eu ainda estava cursando disciplinas no PPGAS/UnB, produzindo os trabalhos finais destas disciplinas e produzindo meus diários de campo.

${ }^{66}$ A versão final deste documento estará disponível ao final desta dissertação.

67 A Polícia Civil do Distrito Federal compõe-se da seguinte estrutura: Direção-Geral da Polícia Civil, Corregedoria-Geral da Polícia Civil, Departamento de Polícia Circunscricional, Departamento de Administração Geral, Departamento de Gestão de Pessoal, Departamento de Gestão da Informação, Departamento de Polícia Circunscricional, Departamento de Polícia Especializada, Departamento de Atividades Especiais, Departamento de Polícia Técnica, Academia de Polícia Civil do Distrito Federal e pelo Conselho Superior da Polícia Civil. As Delegacias de Polícia Circunscricionais são as delegacias de polícia que desempenham atividades voltadas a demandas gerais. O Departamento de Polícia Circunscricional é composto pelas delegacias de polícia. O DF conta atualmente com 38 Delegacias de Polícia, espalhadas em diversas Regiões Administrativas. O Departamento de Polícia Especializada é composto por diferentes Coordenações, Divisões e Delegacias Especializadas. Uma destas delegacias é a Delegacia Especial de Atendimento à Mulher (DEAM). De acordo com Azevedo et al. (2014:31), no Distrito Federal "o atendimento policial a mulheres em situação de violência é feito por uma Delegacia Especializada de Atendimento à Mulher (DEAM), bem como por 31 Seções de Atendimento à Mulher (SAM) presentes em delegais circunscricionais". Para mais informações sobre a estrutura da Polícia Civil do Distrito Federal consultar http://www.pcdf.df.gov.br/ImagensFTP/ATENA/Menu/311.PDF 
conseguiram compreender o andamento, as etapas e o vocabulário da audiência; se em algum momento se sentiram intimidadas ou com medo; como avaliam o atendimento que receberam no Fórum e etc.

O tema do quarto bloco era a avaliação dessas mulheres sobre a Lei Maria da Penha: o que elas sabiam sobre a Lei antes de fazer o boletim de ocorrência; o que elas entendiam como violência no momento em que decidiram procurar a delegacia; o que esperavam quando decidiram acionar a legislação; se se sentiram ou não atendidas pela Lei; se consideravam que a Lei tivesse sido eficiente no caso delas; se a justiça fez o que ela esperavam; se elas procurariam novamente, caso necessário, a justiça em situações de violência doméstica e familiar contra mulheres etc.

No quinto bloco, as questões eram sobre acontecimentos da vida delas após a judicialização dos casos: se a justiça fez o que elas esperavam; se elas se relacionam com o responsável pela agressão e como é esta relação atualmente; se elas consideram que a justiça "apontou soluções" para as situações de violência que foram vividas; qual a opinião delas sobre o desfecho final do processo etc.

Embora essas e outras perguntas estivessem organizadas no roteiro, no momento da entrevista eu respeitava a ordem em que as mulheres apresentavam suas histórias. Era comum que em uma resposta elas falassem e respondessem inclusive perguntas que eu ainda não havia feito. A principal função do roteiro era fazer com que eu não me esquecesse de perguntar sobre determinados temas. Em nenhum momento, o roteiro foi pensado como um instrumento que deveria ser seguido rigidamente ou que eu só pudesse perguntar o que havia sido delimitado pelo roteiro. Ao contrário, em vários momentos, elas apresentaram histórias tão impressionantes que me estimulavam a fazer perguntas que não haviam sido preparadas previamente.

Após ter a versão final do roteiro ${ }^{68}$, eu precisava realizar as entrevistas ${ }^{69}$. Até este momento, eu me preparava para estabelecer com alguma das minhas anfitriãs uma relação mais próxima. Nesta época, estava motivada com a possibilidade de construir minha etnografia tendo como base a história de vida de alguma das mulheres que eu entrevistaria.

Decidi que a melhor forma de contatar aquelas mulheres seria através de ligações telefônicas. O juiz titular do Juizado de Violência Doméstica e Familiar contra a Mulher havia

\footnotetext{
${ }^{68}$ Decidi realizar pequenas modificações no roteiro após a realização das duas primeiras entrevistas. Nessas entrevistas, percebi que havia feito questionamentos importantes que só surgiram com a realização das entrevistas, mas que ainda não constavam no roteiro.

${ }^{69}$ À época, julho de 2014, eu estava me dividindo entre escrever os trabalhos finais das disciplinas que eu havia cursado no 2014/1 e em agendar as entrevistas utilizando os dados que eu havia pesquisado no Fórum.
} 
sugerido que, para entrar em contato com aquelas pessoas, utilizasse algum mecanismo institucional através do Fórum. Ele acreditava que essa atitude poderia facilitar o meu contato com as mulheres e traria mais segurança para mim, enquanto pesquisadora. Embora eu concordasse que a proposta sugerida pelo juiz pudesse efetivamente facilitar o meu contato, aquela não era a estratégia que eu gostaria de utilizar na pesquisa.

Não queria que elas achassem que a pesquisa que vinha desenvolvendo estava ligada ao trabalho da equipe de servidores do Fórum e, principalmente, gostaria que partisse de cada uma a decisão de recusar ou participar. A meu ver, caso eu as contatasse utilizando algum mecanismo institucional, elas poderiam se sentir coagidas a participar da pesquisa. Essa situação poderia gerar uma série de situações de conflitos, como, por exemplo, alguma dessas mulheres acreditar que não participar da pesquisa acarretaria algum problema em relação ao sistema de justiça ou pudesse prejudicá-las de alguma maneira.

Outra forma de contato que eu descartei logo no início da pesquisa foi procurá-las diretamente em suas residências, o que seria possível, já que eu possuía o endereço que elas oficialmente informaram ao $\mathrm{TJDFT}^{70}$. Considerei que essa era uma estratégia de contato extremamente invasiva para aquelas mulheres, além de ser potencialmente perigosa para a minha segurança. Outro ponto que pesava negativamente para que utilizasse essa estratégia é que não sabia os horários em que encontraria essas pessoas em casa, o que poderia me fazer retornar aos endereços inúmeras vezes até conseguir conversar com as mulheres que eu procurava.

Quando comecei o contato através das ligações telefônicas, ingenuamente imaginei que seria relativamente fácil encontrar mulheres dispostas a se tornarem minhas interlocutoras, afinal havia conseguido os dados para contatá-las através da pesquisa nos arquivos do Fórum. Embora eu imaginasse que nem todas as mulheres que contatasse iriam aceitar participar da pesquisa, à época, supunha que o fato de ser uma jovem mulher estudante me ajudaria a entrar em campo. Além disso, havia me preparado para explicar que as entrevistas seriam utilizadas em um trabalho acadêmico e que elas não seriam identificadas.

No entanto, ao longo do trabalho de campo, percebi que além de me apresentar e falar sobre a pesquisa, seria preciso muito mais: negociar a minha entrada, ainda que mínima, na vida daquelas mulheres. Em todos os momentos desta pesquisa, foi extremamente difícil conseguir mulheres dispostas a expor situações dolorosas de suas vidas concedendo

\footnotetext{
${ }^{70}$ Dados pessoais como, por exemplo, nome completo, números de telefone para contato, número de documentos e endereços dessas mulheres estavam disponíveis nos processos.
} 
entrevistas para uma jovem desconhecida que aparecia em suas vidas de uma maneira, no mínimo, incomum.

Comecei a ligar para aquelas mulheres para me apresentar e agendar as entrevistas. É importante retomar que esses onze processos faziam parte do que eu defini como o primeiro recorte da pesquisa, que seria com mulheres que registraram ter passado por situações enquadradas como violência física pela Lei Maria da Penha, cujos processos foram arquivados. Dentro desses onze processos, não consegui estabelecer nenhum contato com cinco mulheres, pois sempre que efetuava as ligações ouvia uma mensagem da operadora de telefone informando que aquele número estava desligado, fora de área ou não existia mais.

Eu ligava para o número que constava no processo e pedia para falar com determinada mulher. Caso a pessoa que atendesse não se identificasse como a mulher requerente no processo ou se outra pessoa atendesse o telefone e perguntasse o meu nome, eu me apresentava como pesquisadora da Universidade de Brasília e que gostaria de entrar em contato com a pessoa que procurava para saber se ela aceitaria ou não participar da minha pesquisa de mestrado. Em nenhum momento, forneci detalhes sobre a pesquisa para qualquer pessoa que não se identificasse como a que eu estivesse procurando. Estou certa de que essa não foi a forma mais segura ${ }^{71}$ para entrar em contato com aquelas mulheres, pois embora não

\footnotetext{
${ }^{71}$ Ao longo da pesquisa de campo, percebi que, embora tenha decidido por essa forma de contato, eu também estava exposta durante o trabalho de campo, como descrevo abaixo. Em 11/11/ 2014, por volta das 14h, liguei para um número de celular que, segundo o processo, pertencia a F. Porém, quem atendeu a ligação foi um homem. Eu disse meu nome, me apresentei como pesquisadora da Universidade de Brasília e disse que gostaria de falar com F. Esse homem perguntou qual era a pesquisa, qual o tema, como eu havia conseguido o número de telefone, de maneira bastante agressiva. Eu respondi que só poderia falar com F. e que ligaria em outro momento, já que ele havia me dito que F. não estava. Antes de desligar, perguntei qual era seu nome e ele me disse que se chamava E. Após a ligação, retornei ao processo e vi que E. era o nome do companheiro de F., requerido no processo, que estava sendo indiciado como agressor de F. Naquele mesmo dia, por volta das $19 \mathrm{~h}$, liguei novamente para o número que constava no processo como sendo de F., dessa vez, utilizando o meu telefone celular. Novamente, quem atendeu foi E. Eu me apresentei como pesquisadora da UnB, disse meu nome e pedi para falar com F. Desta vez, E. foi mais agressivo comigo. Ele disse que não passaria a ligação para F., que pessoas da UnB já haviam ligado para aquele número e que ela não participaria de nenhuma pesquisa. Após isso, E., falando muito alto, ofendeu-me e utilizou expressões de baixo calão para sugerir o que e para onde eu e minha pesquisa deveríamos ir. Fiquei extremamente abalada após essa ligação. Por volta das $21 \mathrm{~h}$, recebi uma ligação do número de F. Não atendi, não saberia como reagir caso fosse ela. Ela estaria utilizando o "viva voz"? Ele poderia me ouvir? Como explicar a pesquisa nessas circunstâncias? Poucos minutos depois, recebi, novamente, uma chamada do número de F. e resolvi atender. Era uma ligação "a cobrar". Assim que a música informando o tipo da ligação acabou, a ligação caiu. Decidi então retornar para aquele número. Quem atendeu foi, novamente, E. Dessa vez ele estava mais agitado. Perguntou porque eu estava ligando para aquele número novamente. Tentando me manter calma eu respondi que eu estava apenas retornando a ligação porque havia recebido duas ligações daquele número minutos antes. Pelo som da ligação percebi que E. estava em um ambiente bastante barulhento. Dessa vez, E. estava mais alterado e falando muito alto. E. disse o seguinte: OLHA, EU ESTOU MANDANDO VOCÊ NÃO LIGAR MAIS PARA ESSE NÚMERO, VOCÊ ESTÁ ENTENDENDO? EU ESTOU MANDANDO! Após terminar a frase, E. desligou a ligação na minha cara. Naquele momento, ficou claro que E. havia ligado apenas com o intuito de me intimidar. Após a ligação, eu fiquei ainda mais abalada. Sentia-me extremamente impotente por não ter conseguido entrar em contato com F. Afinal, se E. perdeu o controle tão rapidamente com uma desconhecida, isso poderia indicar algo sobre o bem estar de F.?
} 
tenha acontecido, alguém poderia ter se passado por uma das requerentes ao telefone. Apesar disto, esta foi a melhor maneira que eu consegui para estabelecer contato com as minhas futuras interlocutoras.

Quando a ligação era transferida para a pessoa que eu procurava ou quando eu conseguia entrar em contato diretamente com as requerentes, apresentava-me e informava pontos importantes sobre a pesquisa. Nesse momento, relatava meu histórico de trabalho em parceria com o Juizado de Violência Doméstica e Familiar contra a Mulher do Fórum Hugo Auler, falando sobre o meu TCC, sobre a minha formação em licenciatura ${ }^{72}$ e bacharelado em Ciências Sociais. Dito isso, explicava como eu consegui aquele número de telefone, dizendo que, após finalizar meu TCC, continuei interessada em pesquisar na área e propus ao juiz responsável pelo Juizado de Violência Doméstica e Familiar contra a Mulher do Núcleo Bandeirante que a minha pesquisa de mestrado fosse realizada a partir de dados obtidos naquele juizado. Após fornecer essa informação, enfatizava que o juiz permitiu que a pesquisa fosse realizada naquele Juizado contanto que meu orientador, o juiz e eu assinássemos um Termo de Compromisso. Explicava que, nesse documento, eu e meu orientador nos identificávamos como as pessoas responsáveis pela pesquisa. Neste momento, enfatizava que nos comprometíamos a manter sigilo e não identificar aquelas mulheres, independente delas aceitarem ou não participar da pesquisa.

Se a mulher com quem eu estivesse conversando hesitasse ou respondesse que não queria participar da pesquisa, eu conversava, explicava novamente a proposta da pesquisa, como tinha conseguido os dados dela e ressaltava que a não-participação não acarretaria qualquer tipo de problema para ela. Nessas situações, enfatizava que ela não era obrigada, de nenhuma forma, a participar da pesquisa e estava livre para poder aceitar ou recusar minha proposta. Também explicava que caso ela aceitasse participar e depois mudasse de opinião, isto não seria um problema e eu respeitaria a decisão tomada por ela.

Nas ligações em que as mulheres recusaram participar da pesquisa, explicava que o meu próximo passo em relação aos dados que coletei do processo no qual ela era requerente seria excluir todos os documentos que faziam qualquer menção a ela do meu arquivo de dados. Se a mulher em questão aceitasse participar, eu a encontraria em local e horário

\footnotetext{
${ }^{72}$ Ao longo do tempo, eu passei a dizer que, embora não estivesse exercendo a profissão à época (eu já havia dado aulas anteriormente), eu também era professora de Sociologia no Ensino Médio. Fornecia essa informação porque percebi que havia uma identificação maior com este ofício, mais conhecido por elas que o ofício desempenhado por antropólogas e antropólogos. Também percebi que me apresentar como professora impunha mais respeito do que falar que eu era estudante de mestrado. Por fim, percebi que através deste ofício elas localizavam mais rapidamente as Ciências Sociais e não confundiam minha pesquisa como pertencente às áreas de Direito ou Serviço Social, como acontecia inicialmente.
} 
estabelecido por ela, apresentaria documentos que me identificassem (minha carteirinha de estudante da UnB, CNH e cópia do Termo de Compromisso) e iria expor detalhadamente a pesquisa.

As ligações eram situações de tensão para mim. Nesses momentos, tive que vencer minha timidez, pois a minha oratória e argumentos foram muitas vezes fundamentais nos momentos em que as mulheres pareciam em dúvida sobre se aceitariam ou não participar da pesquisa. Essa era uma ocasião importante e, em geral, delicada, na qual eu precisava passar o mínimo de confiança para elas. Afinal, é no mínimo inusitado uma desconhecida te ligar, saber seu nome, o seu número de telefone, seus dados pessoais e detalhes sobre um momento delicado e doloroso pelo qual você passou.

Ao encontrar as mulheres que eu iria entrevistar, levava outro documento importante: o Termo de Sigilo e Confidencialidade. Nesse documento, constava a data da entrevista e os seguintes dados que me identificavam perante aquelas mulheres: meu nome completo, número do meu RG (Registro Geral), ${ }^{73}$ o título do meu projeto de pesquisa e o meu número de matrícula na Universidade de Brasília. Através deste documento, eu me comprometia: a) não divulgar a identidade ou quaisquer informações e/ou dados que pudessem ser utilizados para identificá-las, sendo que tudo que fosse dito ali seria utilizado apenas para fins acadêmicos e que eu sempre utilizaria como estratégia a utilização de pseudônimos, para me referir a cada uma delas; b) a gravar as entrevistas apenas se a minha interlocutora autorizasse, sendo que se em algum momento da entrevista ela se mostrasse desconfortável ou pedisse para que eu encerrasse ou pausasse a gravação, isso seria feito. Para cada uma das entrevistas, levava duas cópias do Termo de Sigilo e Confidencialidade: uma cópia ficava comigo e a outra ficava com a minha anfitriã, sendo que todas as cópias deste documento foram assinadas por ambas.

No início da pesquisa de campo, quando ainda estava consultando os dados através do Sistema Interno do TJDFT, imaginava que poderia ser um pouco difícil estabelecer contato inicial com minhas interlocutoras. Porém, o campo se mostrou muito mais complexo do que eu supunha ao começar a pesquisa. Como descrito acima, consegui o contato de onze mulheres que compunham o que defini como o recorte inicial dessa pesquisa.

\footnotetext{
${ }^{73}$ Conforme fui entrando mais a fundo na pesquisa de campo e vivendo situações que me afetaram, passei a me questionar em que medida seria essencial fornecer àquelas pessoas desconhecidas o meu número de RG. Comecei a pensar que essa era uma exposição desnecessária da minha identidade. Optei por continuar com essa informação no Termo de Sigilo e Confidencialidade ao entender que aquelas mulheres se expunham muito mais ao aceitarem compartilhar suas histórias com uma desconhecida e que, se elas aceitavam participar dessa relação, fornecer mais uma informação pessoal que as ajudasse a me conhecer mais e a, quem sabe, confiar mais em mim, era o mínimo que eu poderia fazer.
} 
Dessas onze pessoas, consegui entrar em contato e conversar com seis mulheres que compartilhavam como característica o fato de os processos nos quais eram requerentes terem sido arquivados em datas mais recentes do que as cinco mulheres que eu não consegui contatar. Entre as seis mulheres, apenas uma se mostrou muito interessada em participar, desde o início da ligação. Ela foi a única, durante toda o período de campo, que consegui encontrar e realizar a entrevista logo na primeira vez que marcamos. Dentre as outras cinco mulheres, duas não quiseram participar e demonstraram bastante desconfiança em relação ao meu trabalho.

Com as três interlocutoras que restaram, aconteceu algo que se tornou corriqueiro ao longo da trajetória da pesquisa. Uma eu consegui entrevistar mais de um mês após eu ter feito o contato inicial e dela ter desmarcado outras duas vezes a entrevista. Ou seja, só consegui encontrá-la na nossa terceira tentativa. Embora na primeira ligação as outras duas mulheres tenham aceitado participar da pesquisa, de fato, nós nunca nos encontramos, pois elas agendaram algumas vezes o nosso encontro e, após alguns cancelamentos e antes que eu as encontrasse para realizar a entrevista, elas decidiram não participar da pesquisa.

Essa foi uma atitude constante durante toda a minha trajetória em campo: embora uma parte das mulheres que consegui entrevistar tivesse me dito que poderia procurá-las caso ficasse faltando alguma informação para a minha pesquisa, parecia que elas não se mostravam realmente dispostas a me encontrar novamente ou, de alguma forma, estreitar a convivência comigo através desse tema ${ }^{74}$. A minha impressão é que elas não gostariam de me reencontrar porque, a partir do momento em que nos conhecemos, eu passei a ser uma pessoa que recordava momentos dolorosos.

Em vários momentos, fui questionada se esta pesquisa seria, de alguma forma, utilizada pelo Estado ou se serviria como base para alguma política. Nessas ocasiões, eu explicava que estava interessada em realizar esta pesquisa, sobretudo, porque considero importante conhecer a opinião das mulheres a respeito do processo pelo qual elas passaram quando optaram por judicializar as situações que viveram. Nesses momentos, esclarecia que isto não estava ao meu alcance, que a pesquisa também poderia ser consultada para este fim, mas que o objetivo principal da pesquisa não era $\operatorname{esse}^{75}$.

\footnotetext{
${ }^{74}$ A fala delas, de que eu poderia procurá-las novamente caso fosse necessário, ressoava sempre com uma certa polidez, algo semelhante a quando pessoas conhecidas se encontram e uma delas sugere marcar de tomar um café para conversarem, apesar de terem certeza que isso nunca irá acontecer. Nas vezes que retomei contato através de ligações, embora elas tenham sido cordiais e atenciosas, fiquei com a impressão de que minhas anfitriãs não gostariam de manter contato comigo para falar sobre situações de violência que passaram.

${ }^{75}$ Com o campo, percebi que estes momentos, de certa forma, reprimiam uma aproximação. Afinal, ficava claro que esta pesquisa não "serviria" para mudar realidades, já que esse nunca foi o objetivo desta dissertação e o
} 
Outra atitude que se mostrou recorrente ao longo da minha trajetória de pesquisa foi que muitas das mulheres, que inicialmente se mostravam dispostas a participar da pesquisa no momento das ligações, desistiam algum tempo depois. Essas desistências aconteciam de várias maneiras: no dia da entrevista ou um dia antes, eu ligava para a requerente para confirmar a entrevista e muitas utilizavam esse momento para cancelar a entrevista, alegando outros compromissos que surgiram ou que já estavam marcados, mas que haviam esquecido; outras, mesmo após confirmarem a data e o horário através da ligação, simplesmente não apareciam no local combinado (ou não abriam a porta, caso o local combinado fosse a residência delas). Outras sempre pediam para eu ligar mais adiante, na próxima semana e, muitas vezes, prolongavam essa situação por semanas e até meses; e outras, embora inicialmente tivessem concordado em participar da pesquisa, simplesmente desapareciam e não atendiam mais minhas ligações para agendar a entrevista.

Mais uma situação recorrente é que as mulheres que decidiam participar sempre perguntavam qual o tempo de duração da entrevista e se elas precisariam me encontrar mais de uma vez. Nesses momentos, eu explicava que a entrevista durava, em média, 1 hora e que se conseguíssemos realizá-la de uma só vez, não precisaríamos nos encontrar novamente. Essa foi uma situação que me fez pensar muito sobre o tempo que elas doavam à pesquisa e sobre o fato delas me questionarem sobre a necessidade de mais de uma entrevista. A minha hipótese é que, com isso, elas procuravam me informar que as situações que haviam vivenciado foram muito intensas e que elas não gostariam de ficar revivendo-as.

É importante destacar que, nas entrevistas, as mulheres foram muito generosas comigo, principalmente por fornecerem detalhes íntimos de suas trajetórias. Apesar disso, nenhuma das minhas interlocutoras forneceu abertura para que eu conseguisse me aproximar o suficiente para realizar um estudo de caso. A despeito de terem se oferecido para participar novamente de uma entrevista, caso eu necessitasse de mais alguma informação complementar para a pesquisa, ficou claro para mim que elas não gostariam de me reencontrar outras vezes e "recontar" situações que passaram.

Após essas experiências, percebi que minha perspectiva inicial de realizar um estudo de caso não seria possível com nenhuma das mulheres que eu consegui entrevistar. Eu já

poder de transformar realidades através da gestão ou criação de políticas nunca esteve em minhas mãos. Esses momentos contribuíram para que eu repensasse e questionasse a minha prática em campo, a disciplina e o seu potencial para modificar situações. Ao construir este capítulo, reli um texto que, de certa forma, me reanimou. Ao defender a prática etnográfica, a autora argumenta, entre outros pontos, que é também "na sensibilidade para o confronto ou o diálogo entre 'teorias acadêmicas e nativas' que está o potencial de riqueza da antropologia" (PEIRANO, 1992:10), que, segundo a autora é a "disciplina dos artesãos, microscópica e detalhista e que reconhece, na sua prática cotidiana, a temporalidade das explicações” (1992:15). 
havia acessado todos os processos que estavam no arquivo do Fórum e que se encaixavam no meu recorte inicial, mas ou eu não consegui contatar as mulheres requerentes ou, quando consegui, as mulheres se recusaram a participar da pesquisa.

\section{4 - Os imponderáveis da vida real e os novos recortes da pesquisa}

Quando construí meu projeto inicial de pesquisa, não contava com esse tipo de dificuldade. Contudo, o próprio Malinowski (1978) entendia que "acontecimentos imponderáveis" fazem parte da pesquisa antropológica e, consequentemente, do conhecimento produzido por antropólogos. Estes "acontecimentos imponderáveis" presentes no campo contribuem para que possamos acessar aspectos da vida social que são diferentes do que havia sido inicialmente planejado.

Sobre estes acontecimentos, Peirano (1992:120) reflete que os "imponderáveis da vida real" não invalidam, mas, ao contrário, enriquecem e fornecem a dimensão humana essencial à compreensão dos fenômenos sociológicos. Peirano defende que a pesquisa de campo também depende da "biografia do pesquisador, das opções teóricas presentes na disciplina, do contexto sociohistórico mais amplo e, não menos, das imprevisíveis situações que se configuram entre pesquisador e pesquisados no dia-a-dia da pesquisa" (1992:124).

Para continuar a pesquisa, foi necessário fazer algumas escolhas: ou eu manteria o recorte e iria buscar a autorização para fazer pesquisa com os arquivos que estavam localizados no Setor de Armazenagem e Abastecimento Norte (SAAN) ou eu ampliaria o recorte. A minha experiência de campo foi fundamental nesse momento de decisão. Eu havia percebido que era muito mais fácil contatar mulheres cujos processos haviam sido arquivados mais recentemente, pois a chance de eu conseguir encontrá-las através do número de telefone que constava em documentos presentes no processo era maior. Conforme os processos se tornavam mais antigos, a possibilidade de as mulheres terem trocado de número de telefone aumentava.

Foi então que decidi trabalhar com os processos que haviam sido "recentemente" arquivados pelo Juizado de Violência Doméstica e Familiar contra a Mulher do Núcleo Bandeirante. Naquele momento, já havia tentado entrar em contato, na maioria das vezes sem sucesso, com as requerentes que alegaram, durante o registro do $\mathrm{BO}$, terem passado por situações de violência física e cujos processos foram encerrados ${ }^{76}$. Em vista disso, decidi que

\footnotetext{
${ }^{76}$ Em fevereiro de 2012 o Supremo Tribunal Federal (STF) julgou a Ação Direta de Inconstitucionalidade 4224, ajuizada pela Procuradoria-Geral da República referente aos Arts. 12, 16 e 41 da Lei 11.340/2006. O STF
} 
ampliaria o recorte da pesquisa para contemplar mulheres que relataram ter passado por qualquer uma das situações de violência doméstica previstas na Lei Maria da Penha.

Procurei os processos que se encaixavam nas características acima e os classifiquei cronologicamente estabelecendo o critério “dos mais recentes para os mais antigos". Um ponto importante é que, apesar de os processos que eu consultava terem sido arquivados recentemente, isso não significava que a acusação descrita no processo tivesse acontecido há pouco tempo. Por exemplo, um processo que tinha sido arquivado em agosto de 2014, tinha maio de 2013 como data de comunicação do fato registrado no Boletim de Ocorrência. Ou seja, os processos levavam uma média de dez a doze meses até serem arquivados, podendo acontecer de processos serem arquivados em menor tempo ou em um tempo muito maior que este.

Nessa etapa de mudança do recorte da pesquisa, foi mais uma vez fundamental a ajuda de servidoras do TJDFT, principalmente as que trabalhavam no Centro Judiciário da Mulher e no cartório do Juizado de Violência Doméstica e Familiar contra a Mulher do Fórum Hugo Auler. Através delas eu consegui buscar novos processos, com o recorte exposto acima, no Sistema Interno do TJDFT. Essa consulta gerou outra planilha que tinha como dados os números dos processos que eu consultava e a data em que eles foram arquivados. Com essa planilha em mãos, retornei ao Arquivo do Fórum para pesquisar os dados nestes processos.

Embora o recorte mais amplo tenha trazido facilidades, as dificuldades em contatar e encontrar as mulheres permaneceram. Durante minha pesquisa no Arquivo do Fórum, eu acessei dados referentes a 82 processos. Desse total, estavam no Arquivo do Fórum 59 processos, que tinham como requerentes 59 mulheres. Liguei para todos os números de contato referentes a esses processos, mas, ao final, só consegui realizar mais 10 entrevistas. Apesar de ter conseguido entrar em contato com a maioria dessas mulheres, continuei enfrentando vários problemas no campo. Houve algumas mulheres que já no contato telefônico recusavam participar da pesquisa. Tive que dedicar muito tempo às mulheres que, inicialmente, aceitaram participar da pesquisa, mas que ou desmarcavam, ou não atendiam mais minhas ligações ou simplesmente não apareciam no local e horário combinados. De maneira geral, as participantes que me concederam entrevistas desmarcaram ou cancelaram o

compreendeu que, nos casos em que há lesão corporal, o Ministério Público dar início a ação penal sem necessidade de representação da vítima. Sobre este aspecto é oportuno consultar: http://www.stf.jus.br/portal/cms/verNoticiaDetalhe.asp?idConteudo=199853;

http://www.stf.jus.br/portal/cms/verNoticiaDetalhe.asp?idConteudo=199847\%3E http://www.stf.jus.br/portal/processo/verProcessoAndamento.asp?numero=4424\&classe=ADI\&origem=AP\&rec urso=0\&tipoJulgamento=M. É importante destacar que algumas das minhas anfitriãs foram requerentes em processos julgadas antes dessa decisão. 
encontro uma, duas, três, quatro, cinco vezes! E essa foi uma situação que gerou inúmeras frustrações ao longo da pesquisa.

A cada semana um novo desencontro. Nesse sentido, meu diário de campo foi fundamental para a realização dessa pesquisa. Ele me permitiu anotar cada fato observado, casa situação vivida, cada caminho percorrido até conseguir encontrar as mulheres que eu tanto procurava. Através dele, consegui "costurar" as entrevistas realizadas, as situações vividas durante essa pesquisa, as descobertas que o campo me proporcionou. Durante todo o tempo que trabalhei na pesquisa, produzi o diário. Estão lá as descrições e impressões sobre cada uma das entrevistas, as frustrações após programar o meu dia para um encontro que não aconteceu, as esperas, as ligações não atendidas. Foi a partir do diário, mais do que dos áudios das entrevistas realizadas, que pude me aventurar em "construir os dados", que, separados, eram "incompletos". E, só a partir de então, tecer trajetórias ficcionais, no sentido proposto por Geertz (1978), a partir de todas as histórias que vivenciei e vidas que conheci. É importante ter em mente que as histórias que serão apresentadas são ficcionais, pois também foram construídas através das minhas percepções em campo enquanto antropóloga, mas de forma alguma são falsas.

Uma vez explicitada a trajetória da pesquisa e a entrada em campo, é necessário oferecer mais informações sobre as minhas interlocutoras e sobre suas percepções acerca da Lei Maria da Penha e da experiência que tiveram com o sistema de justiça. No próximo capítulo, apresentarei minhas anfitriãs, suas diferentes trajetórias e a diversidade de experiências que elas relataram quando foram até às delegacias para acionar a Lei 11.340/2006 e judicializarem as situações de violência pela qual passavam. 


\title{
CAPÍTULO 03 - Sobre os (des)caminhos percorridos nas doze trajetórias
}

\begin{abstract}
"Aí eu disse que caberia sim, porque Lei Maria da Penha não é só bater. Aí eu abri o artigo lá, da Lei Maria da Penha, no artigo sétimo, que fala sobre a agressão moral, essas coisas. Aí eu fui provar para ele, porque se ele não desse medida protetiva... Porque muitas vezes os casos acontecem, porque a gente pensa que não vai acontecer e acaba acontecendo" Ana Clara.
\end{abstract}

No capítulo anterior, estive preocupada em apresentar a trajetória da pesquisa e o processo de construção de dados. Neste capítulo, privilegio os relatos das entrevistas e me dedico à análise das diversidades presentes nas trajetórias que elas relataram. Aqui, apresento minhas anfitriãs, as mulheres que aceitaram participar desta pesquisa me recebendo e compartilhando as histórias e experiências de suas vidas, durante o trabalho de campo necessário para a construção desta dissertação.

Minhas anfitriãs relataram as experiências que viveram quando decidiram ir até à delegacia acionar o atendimento previsto pela Lei Maria da Penha para mulheres em situações de violência. Porém, essas mulheres passaram por experiências muito diferentes. Esse capítulo tem como fio condutor a diversidade de atendimento que essas mulheres relatam sobre como foram tratadas pelo sistema de justiça criminal ao recorrerem à LMP.

Com o campo, percebi que o atendimento que elas disseram ter recebido ao acionarem o sistema de justiça criminal e utilizarem o serviço prestado por policiais militares e/ou pelos diversos servidores que atuam nas delegacias foi bastante diverso. A maneira como elas foram atendidas por policiais militares chamados ao local em que houve a ocorrência e/ou nas delegacias, a duração do processo e a trajetória que elas percorreram até o julgamento final é fundamental para compreendermos as frustrações, satisfações e modo como minhas anfitriãs compreendem a atuação do sistema de justiça nos processos em que elas eram requerentes. São dados que considero importantes, pois contribuíram, efetivamente, para que as expectativas e percepções das minhas interlocutoras sobre à Lei 11.340/06 fossem bastante variadas.

Compreendo que quando as mulheres decidem ir até à delegacia, elas estão "judicializando" as situações de violência vivenciadas, já que nesse momento procura-se o auxílio do Estado, mais especificamente do sistema de justiça criminal, para a resolução dos conflitos. Desta forma, utilizo a interpretação proposta por Rifiotis (2012:32) que compreende 
“judicialização" como "um conjunto de práticas e valores pressupostos em instituições como a Delegacia da Mulher e que consiste em interpretar a violência sofrida por mulheres a partir de uma leitura criminalizante".

\section{1 - Ana Clara - "Aí da segunda vez eu levei a gravação, passei para um CD e deixei na delegacia"}

Ana Clara foi uma das mulheres que afirmou ter pouco tempo para me encontrar. Por isso, escolheu me receber no seu emprego, durante o período matutino, em um horário pouco movimentado. Ana Clara nasceu em Minas Gerais, tem cerca de 30 anos, é pedagoga e frequenta, no período noturno, o curso de Direito em uma faculdade localizada no Plano Piloto. Ela trabalha em dois empregos, um durante toda a madrugada e outro no período da manhã até o início da tarde. Na época em que decidiu denunciar o ex-companheiro, Ana Clara morava na Candangolândia ${ }^{77}$.

Minha anfitriã conheceu o ex-marido na primeira vez em que ela foi à boate, quando tinha dezoito anos, em 2006. Ele foi o seu primeiro namorado. Ana Clara conta que os dois se envolveram com rapidez, principalmente porque não tinham família em Brasília. Pouco tempo depois que se conheceram, decidiram morar juntos. Entre idas e vindas, o relacionamento durou cerca de três anos.

Em menos de um ano morando juntos, Ana Clara engravidou. Minha anfitriã diz que os problemas do casal começaram no final da gravidez. Durante esse período, o companheiro começou a ficar distante e viajar sem a companhia de Ana Clara, seja com amigos ou para visitar a família dele, que morava em outro estado.

Ana Clara conta que a pior briga que tiveram foi quando ela estava grávida de nove meses, em uma festa que o casal ofereceu na casa em que moravam para comemorar o aniversário dela. Naquele dia, ela descobriu que ele iria viajar sem tê-la avisado. O casal começou a discutir e ela conta que começou a quebrar objetos da casa por estar muito nervosa. Durante a briga, ele atirou em Ana Clara um ferro elétrico, mas felizmente ela conseguiu se desviar. Ela conta que essa foi a única vez que o ex-companheiro tentou agredila fisicamente. Ela não prestou nenhuma queixa contra o ex-marido, mas pouco tempo depois o casal decidiu se separar. Após o bebê completar um mês de vida, o pai da criança saiu de casa.

$77 \mathrm{Na}$ ocasião da entrevista, Ana Clara havia mudado de endereço e não morava mais nessa Região Administrativa. 
Algum tempo após o nascimento da criança, Ana Clara foi diagnosticada com depressão pós-parto. Ela conta: "Eu estava depressiva... A palavra ali passa, mas tem coisas que a pessoa fala com você e que assim... Ele falava muito sobre a minha família”. Esse era um aspecto importante para minha anfitriã, pois Ana Clara tinha um relacionamento complicado com a família dela e seu então companheiro costumava se referir a isso quando o casal discutia. Nesta época, Ana Clara avaliou que não possuía condições de cuidar do bebê e permitiu que a sogra, que morava em outro estado, viesse buscar a criança, que à época estava com quatro meses de vida.

Antes de a criança completar um ano de idade, Ana Clara havia se recuperado e trouxe o nenê novamente para Brasília. Minha anfitriã relata que mesmo após o casal ter se separad,o o ex-marido frequentava a casa dela para visitar a criança e eles sempre brigavam. Embora o ex-companheiro de Ana Clara tenha começado um relacionamento com outra mulher, frequentemente ele a assediava para que retomassem o relacionamento e ela nunca aceitava.

Com o tempo, as ameaças, ofensas e xingamentos proferidos pelo ex-companheiro, principalmente através do telefone celular, tornaram-se mais recorrentes. Ana Clara notou que essas ações aumentaram principalmente quando o ex-companheiro percebeu que, após a separação do casal, ela havia conseguido ter acesso a diversos bens de consumo e maior independência financeira.

Em 2013, Ana Clara ajuizou uma ação cível contra o ex-parceiro para regulamentar a pensão alimentícia e as visitas ao filho do casal, o quê, segundo ela, irritou-o profundamente. Por cerca de três meses, ele passou a ameaçá-la e a proferir diversas ofensas e xingamentos, através de ligações ou pessoalmente. Ana Clara conta que uma das ameaças mais marcantes foi quando o ex-companheiro disse que iria "colocar fogo" no carro que ela havia comprado.

Ana Clara não compartilhou com ninguém as primeiras ameaças efetuadas pelo excompanheiro. Minha interlocutora conta que quando recebeu a quarta ligação do ex-marido estava na faculdade e ficou tão perturbada que comentou com uma amiga do curso de direito sobre as ameaças e o medo que sentia de que elas pudessem ser concretizadas. Essa amiga recomendou que Ana Clara fosse à delegacia e utilizasse a Lei Maria da Penha para denunciar o ex-companheiro, mas que antes disso ela gravasse as ameaças.

Minha anfitriã diz que essa conversa foi fundamental para que ela acionasse a LMP: "Na minha visão, Maria da Penha era só para lesão corporal, porque eu sempre via na TV essas coisas. Depois eu pesquisei, comecei a ler a lei, os artigos e aí eu achei o Art. $7^{\circ}$ falando sobre violência física, verbal e tal. Aí que eu procurei ajuda, porque antes eu achava que era só a questão da lesão". 
Nesse caso, a rede afetiva de Ana Clara foi fundamental para que ela acessasse a LMP. Foi a amiga de Ana Clara, que conhecia mais detalhes sobre a legislação, que a encorajou a denunciar as ameaças, dizendo que a LMP também poderia ser acionada nessas situações. Logo, o fato de, na época da denúncia, Ana Clara cursar a graduação em direito foi fundamental para que ela registrasse ocorrência contra o ex-companheiro. Esse acontecimento da margem a diversas especulações: Será que se Ana Clara não frequentasse aquele espaço, ela continuaria pensando que a LMP só poderia ser acionada em casos em que há violência física?

Esse é um aspecto importante. Algumas das minhas interlocutoras relataram que somente na delegacia ou no Fórum descobriram que a LMP poderia ser acionada em situações de violência que não fossem agressões físicas. Outras só acionaram a LMP quando passaram por situações de agressão física porque não conheciam as formas de violência doméstica e familiar contra a mulher previstas na legislação. Já Ana Clara só conheceu detalhes sobre a legislação porque, após a conversa com a amiga, "foi procurar e estudar a lei”.

Minhas interlocutoras conheciam, ao menos parcialmente, a Lei Maria da Penha, devido a toda publicidade que surgiu desde 2006 com a promulgação dessa legislação. Entretanto, apesar de a lei ter sido amplamente divulgada, elas sabiam apenas que se tratava de legislação cujo objetivo é coibir a violência doméstica, mas não estava claro para muitas delas que existiam outros tipos de violência previstos na lei. Algumas conseguiram acessar esse conhecimento quando procuraram a delegacia. Porém, outras só descobriram esse aspecto da legislação no encontro com a equipe de atendimento multidisciplinar, já no Fórum. Ana Clara traz uma terceira situação: ela conheceu detalhes sobre a LMP porque foi pesquisar e estudar sobre o assunto $^{78}$.

Assim que Ana Clara compreendeu que a Lei Maria da Penha também poderia ser acionada em situações de ameaça e de agressão verbal, decidiu ir até à delegacia circunscricional que atendia a região que morava para denunciar o ex-companheiro. É importante destacar que Ana Clara foi à mesma delegacia que Carolina, outra interlocutora. Como veremos, elas receberam atendimentos muito diferentes.

Voltando ao relato de Ana Clara, ela conta que "achou estranho" não ter recebido nenhuma comunicação do Fórum, após ter registrado o boletim de ocorrência (BO), acerca

\footnotetext{
${ }^{78}$ Esse aspecto pode nos ajudar a refletir sobre as maneiras pela qual a LMP foi divulgada. Muitos dos materiais de divulgação da LMP que acessei, ao me informar sobre a lei, privilegiavam imagens em que mulheres haviam sido agredidas fisicamente. Porém, essa é apenas uma percepção pessoal sobre a divulgação da legislação, tendo em vista que não conheço pesquisas ou dados relevantes que contribuam para esse debate. Talvez, essa seja uma lacuna a ser preenchida por pesquisadores que se interessem sobre a temática.
} 
das medidas protetivas de $\operatorname{urgência}^{79}$ que ela havia solicitado. Ana Clara me explica que, com a sua pesquisa sobre a LMP, descobriu que a legislação previa que as medidas protetivas de urgência fossem concedidas em poucos dias. Além de não ter recebido nenhuma notificação sobre as medidas protetivas, ela também não sabia se o inquérito havia sido encaminhado para o Fórum.

Neste intervalo de tempo, minha anfitriã conta que continuou sendo ameaçada pelo exmarido pelo telefone. Ela relata que alguns dias após ter feito a denúncia, decidiu fazer uma nova visita à delegacia, pois começou a desconfiar que o inquérito pudesse ter ficado "parado". Desta vez ela gravou o áudio de uma ligação efetuada pelo seu ex-companheiro. O áudio em questão continha insultos e ameaças proferidas contra minha interlocutora: "Ele disse que ia tacar fogo no meu carro porque eu estava me achando demais, e nem que ele fizesse alguma besteira, que ele não estava nem aí, nem que para isso ele tivesse que tirar minha própria vida". Cito Ana Clara:

\begin{abstract}
O meu processo ficou parado. Tipo assim, eu acho que não chegou nem a descer para o juiz. Porque, no dia que eu fui falar com o agente... Bom, porque não é o delegado que te atende, é o agente, é o escrivão que te escuta. Aí depois eu voltei, fui e falei para o delegado: - Olha, minha medida protetiva não saiu e isso, isso e isso e ele está me ameaçando... E expliquei o caso de novo. Aí eu falei: - Está aqui a gravação. Aí o delegado parou e escutou a gravação. (...) Eu acredito que eles não me deram assistência (na primeira vez que ela foi à delegacia) porque eu só cheguei e falei. Aí, da segunda vez eu levei a gravação, passei para um CD e deixei na delegacia. Aí o delegado escutou e viu que realmente era grave, porque nesse momento ele já havia me ameaçado de morte.
\end{abstract}

Muito provavelmente, a suposição de Ana Clara estava correta e a ocorrência que ela registrou não tinha sido levada adiante por ser considerada, por quem a atendeu, como um “caso sem relevância” (SOUZA, 2007:09). Erika Giuliane Andrade Souza (2007), que fez trabalho de campo em delegacias localizadas no Rio de Janeiro, explica que estes são os chamados "casos de feijoada".

Segundo Souza, além do arcabouço jurídico, o trabalho policial também é baseado em "valorações culturais e costumes compartilhados entre os policiais em que são estabelecidas trocas simbólicas (de bens materiais, serviços), entre os atores, que influenciam o tratamento dos casos" (p.01). A partir de etnografia feita em delegacias de polícia, Souza analisou

\footnotetext{
${ }^{79}$ Procurei ao longo de toda a pesquisa e escrita ser honesta com minhas interlocutoras e com tudo que elas me contaram. Porém, devido ao espaço, formato e ao que se espera de uma dissertação de mestrado, é totalmente inviável apresentar com detalhes todas as histórias que me foram contadas. Por isso, destaco que embora várias interlocutoras tenham falado sobre as Medidas Protetivas de Urgência uma das minhas escolhas nesta dissertação foi escolher casos emblemáticos, que ajudassem a refletir sobre todo o atendimento oferecido.
} 
avaliações de policiais sobre o que seria ou não considerado um conflito válido para ser atendido com registro de ocorrência e levado adiante através de investigação policial.

Um ponto importante é que a classificação dos casos leva em consideração vários aspectos, tais como status social do envolvido, se é homem ou mulher, se a pessoa está acompanhada de advogados, se está chorando, nervosa etc. O bairro em que a delegacia está localizada também é um fator importante para classificação dos casos. De acordo com Souza, em delegacias localizadas em regiões periféricas, os policiais eram tratados como "autoridades". Por outro lado, em regiões valorizadas do Rio de Janeiro, era comum que a população atendida tratasse os policiais como "empregados particulares".

De acordo com Souza, os policiais civis utilizam o termo "casos de feijoada" para classificar, por exemplo, "brigas entre marido e mulher, brigas entre vizinhos, brigas que ocorrem em bares e com profissionais do sexo" (2007:09) etc. No entanto, Souza (2007:0809) explica que a "feijoada" possui diversas definições: casos sem relevância; casos que poderiam ser resolvidos entre as partes; casos de pequeno potencial ofensivo que poderiam ser resolvidos através de conversas; confusões que passam por xingamentos até lesões corporais leves etc. Em suma, são casos que os policiais não atribuem muita importância.

Esse é um aspecto que chama muita atenção no relato de Ana Clara. Ela utilizou a LMP como recurso para que ela conseguisse romper com uma situação de violência que a colocava em riscos. Pasinato (2007:11) relata que pesquisas demonstraram que para algumas mulheres o empoderamento "pode estar representado na possibilidade de romper a relação violenta e construir uma nova vida longe do parceiro agressor". Este era o desejo de Ana Clara, utilizar a LMP como um instrumento que a permitisse viver uma vida sem as ameaças e agressões do ex-companheiro.

A questão aqui é que o sistema de justiça que deveria auxiliá-la através dos mecanismos previstos na legislação para coibir e prevenir situações de violência doméstica, funcionou como mais uma barreira para minha anfitriã enfrentar. O registro de Ana Clara só foi adiante porque ela resolveu insistir. Sobre esse aspecto, ela relata que além da gravação, levou para a delegacia uma versão impressa da Lei 11.340/2006, para ser utilizada caso a contestassem sobre a legalidade da legislação para situações em que não houvesse agressão física. Assim que foi atendida, Ana Clara pediu para que os servidores ouvissem o conteúdo do áudio e diz que ainda assim foi questionada: 
Penha não é só bater... Aí eu abri o Art. $7^{\circ}$ que fala sobre a agressão moral, essas coisas. Aí eu fui provar para ele, porque se ele não desse a medida protetiva... Porque muitas vezes os casos acontecem, porque a gente pensa que não vai acontecer e acaba acontecendo.

Minha anfitriã relata que $24 \mathrm{~h}$ após a sua segunda ida à delegacia, foi concedida medida protetiva de urgência contra o seu ex-companheiro. Na trajetória que Ana Clara percorreu quando judicializou a situação de violência que passava, o conhecimento que ela adquiriu sobre a legislação ao longo de todo esse processo foi fundamental para o prosseguimento da sua denúncia. Aqui, a legislação e os serviços oferecidos pelo sistema de justiça não foram suficientes para atender as demandas da minha anfitriã. Sobre esse aspecto, cito Pasinato (2015:535): "Dia após dia se fortalece o entendimento de que o sucesso da Lei está ameaçado pelas muitas falhas que se identificam em sua aplicação”. A seguir, apresento Alice, que viveu situação parecida com a de Ana Clara, embora tenha ido à uma delegacia diferente.

\section{2 - Alice - "Praticamente viraram para a minha cara e me mandaram ir para casa. Se tivesse que acontecer alguma coisa, tinha acontecido".}

Alice tem pouco mais de 30 anos e se relaciona há 13 anos com o companheiro que conheceu quando cursava o Ensino Médio. Quando nos conhecemos pessoalmente, em outubro de 2014, ela havia acabado de sair do emprego de vendedora em um shopping para se dedicar aos estudos e à família. Com o tempo livre que passou a ter, Alice cursava aulas para tirar a habilitação e poder utilizar o carro que ela e o marido compraram, o que, em suas palavras, iria "facilitar mais a vida".

À época da entrevista, além de frequentar as aulas de direção e realizar atividades domésticas, durante o dia Alice também cuidava dos seus cinco filhos, a mais velha com 11 anos e a mais nova com 7 anos de idade. Durante a noite, Alice frequentava, com o auxílio de um programa do Governo Federal, os últimos semestres do curso de Administração em uma Instituição de Ensino Superior localizada em outra Região Administrativa, diferente do local em que ela residia. Alice disse que, no futuro, o marido também pensava em cursar o Ensino Superior, mas que naquele momento ele ficava em casa à noite para cuidar das crianças.

Minha anfitriã conta que, em 2010, o marido começou a mudar de comportamento, tornando-se mais agressivo com ela. A briga que gerou o processo através do qual eu a conheci ocorreu após o marido de Alice discutir com o garçom do bar em que estavam sobre a temperatura da cerveja. Após esse momento, Alice voltou para casa. Quando o marido chegou 
em casa, a discussão recomeçou, porém mais intensamente, com o casal proferindo ofensas e xingamentos. Ela conta que neste segundo momento, ambos permaneceram alterados e que ela recorda que os dois estavam alcoolizados.

Alice relata que conforme ela e o companheiro ficaram mais exaltados, ambos começaram a falar cada vez mais alto. Nesse momento, minha interlocutora e o marido foram apartados pela cunhada e pelo sogro, já que Alice e o companheiro residiam no mesmo lote que a família do marido. Mesmo assim, o casal continuou se agredindo verbalmente. Alguns minutos após o pai de seu companheiro tê-lo segurado, o marido conseguiu se desprender e, imediatamente, agrediu Alice com chutes, tapas, puxões de cabelo e socos, além de ameaçá-la de morte. Após esse acontecimento, Alice foi à delegacia.

Outro aspecto importante presente na fala de Alice relaciona o período em que ela considerava denunciar o companheiro pelas agressões que esse cometia, mas não o fazia devido a situação econômica na qual se encontrava. Minha anfitriã relatou que, inicialmente, tinha receio de denunciar o marido porque a renda dele era fundamental para o sustento econômico da família. Alice disse que "era meio que forçada" a não denunciar o marido. Eu a questionei sobre os motivos que a "forçavam" a continuar na relação e ela argumentou dizendo que "era totalmente dependente dele". Nas palavras de Alice: "Como é que sustenta uma família com cinco crianças? Querendo ou não, eu trabalhava, mas eu ganhava muito pouco... Como que eu ia fazer pra pagar aluguel? Hoje não. Se eu vier me separar dele eu me viro tranquilamente..."

Alice conta que ela não sabia muitos detalhes sobre a Lei Maria da Penha antes de utilizá-la pela primeira vez, apenas que essa era uma legislação que punia a violência doméstica. Após essa última briga, ela decidiu denunciar o companheiro. Cito minha interlocutora:

\footnotetext{
Eu denunciei porque eu queria que não acontecesse mais. Para resolver essa situação, para não ter uma segunda, uma terceira (...). Hoje não, mas no dia... Eu fiquei muito revoltada pela situação, por ele não ter sido preso. Se tivesse que acontecer alguma coisa, tinha acontecido. Porque eu voltei para casa, ele estava lá, eu peguei as crianças e fui para a casa da minha mãe.
}

Durante o nosso encontro, Alice chamou bastante atenção para o atendimento que recebeu na delegacia, ao decidir denunciar o seu companheiro. Minha anfitriã conta que já havia registrado duas ocorrências (motivadas por brigas, ofensas e ameaças) contra o companheiro na delegacia circunscricional próxima à sua residência em anos anteriores. Alice conta que o casal já havia passado por uma audiência judicial e que, naquela ocasião, ela 
optou por arquivar o processo, pois o marido havia se comprometido a mudar e ambos decidiram permanecer com o relacionamento.

Após a briga, minha anfitriã foi à delegacia circunscricional mais próxima a sua casa, mas não ficou satisfeita com o atendimento que recebeu. Ela conta que pouco tempo após ter chegado à delegacia, o seu marido apareceu por lá e também conversou com o delegado. Alice relata que o marido disse ao delegado que tinha a agredido porque descobriu que ela o traía. Nesse momento, minha anfitriã demonstrou que ainda se sentia ofendida por essa situação e foi veemente ao afirmar que nunca traiu o companheiro, mas que o delegado a "colocou contra a parede" e disse que ela "também estava errada". Sobre esse aspecto, Alice diz: "Se o cara quisesse matar a mulher ele matava. Você vai lá para dar parte da pessoa e o delegado tem que deixar a pessoa presa, mas libera porque a pessoa falou que foi traída. Independente do que tenha sido, né? E aí a pessoa pode matar... Então nessa parte aí eu achei falho".

Aos poucos, minha anfitriã foi revelando mais sua decepção com o atendimento que recebeu na delegacia. Sobre essa ocasião, Alice disse que na delegacia não a trataram com a atenção que ela esperava e que "praticamente" a mandaram ir para casa: "Se tivesse que acontecer alguma coisa, tinha acontecido. Porque eu voltei para casa, ele estava lá, eu peguei os meninos e fui para a casa da minha mãe". Sobre o atendimento que recebeu na delegacia, ela conta:

\footnotetext{
Alice: - Eu acho que delegacias são muito falhas. No dia que eu cheguei para fazer ocorrência, aí ele logo chegou também e o delegado foi e falou com ele e tal. Ele chegou a falar para o delegado que ele tinha sido traído e por isso que tinha chegado aquele ponto! Aí o delegado veio conversar comigo, querendo tipo... Colocar pressão sabe? Krislane: - Então ele acreditou na história do seu marido? Alice: Isso! Ele disse 'seu marido está falando aqui que fez isso porque você o traiu. Você sabe que você está errada, que você pode perder a guarda das crianças!'. E naquele momento ali, você quer socorro! Você não quer saber do que aconteceu, se foi ou se não foi. Eu só sei que ele não ficou detido. Era para ele ter ficado, né. Mas ele não ficou. Ele foi liberado.
}

Minha anfitriã continua: “Como se tivesse uma justificativa! E na verdade eu não traí! Mas aquela coisa... Querendo arrumar um pretexto, uma desculpa para o que tinha feito". Através do relato de Alice, é possível compreender que o delegado apoiou a fala do marido de Alice por considerar que minha anfitriã havia praticado um ato reprovável e que, de certa forma, havia recebido uma "correção".

Lia Zanotta Machado e Maria Tereza Bossi de Magalhães (1998) em pesquisa realizada ainda na década de 1990 já chamavam atenção para a associação entre a violência e 
o disciplinar, invocado como correção através de agressões. Segundo as autoras (p.37): “Os agressores alegam que as mulheres não obedeceram ou não fizeram o que deviam ter feito em nome dos filhos ou do fato de serem casadas. A violência é sempre disciplinar. Eles não se interpelam sobre o porquê agiram desta ou daquela forma”. Nesse caso, o delegado que atendeu o casal aceitou o argumento de que o companheiro de Alice a agrediu para "corrigir" um comportamento considerado inadequado. Ou seja, segundo a fala de Alice é possível inferir que, para o delegado, a agressão física era justificada.

Alice também destaca que, durante o atendimento, o delegado "lembrou" que ela poderia perder a guarda dos filhos do casal por, supostamente, ter traído seu companheiro. Embora ela tenha conseguido registrar a ocorrência, o delegado que a atendeu não tratou com consideração as demandas de Alice. Ela finaliza dizendo que após o registro do boletim de ocorrência (BO) ambos foram liberados.

Azevedo e Vasconcelos (2012:558) afirmam que apesar de a legislação ter sido minuciosa ao orientar a atividade policial, "são conhecidas de todos as dificuldades existentes, tanto estruturais quanto culturais, para que esses delitos venham a receber por parte da polícia o tratamento adequado". A questão aqui é que o discurso proferido pelo marido de Alice foi aceito pelo delegado responsável no momento do atendimento, e esse não ofereceu as providências previstas na legislação por concordar com o argumento construído pelo companheiro de Alice que, de certa forma, culpabilizava Alice pela agressão que ela sofreu.

Após o episódio da delegacia, Alice decidiu sair da casa em que morava com o marido, mudando-se com os filhos do casal para a casa da sua mãe. Ela conta que optou por sair da casa em que morava porque ela, o companheiro e os filhos do casal dividiam o lote com a família do marido. Esse foi também o motivo pelo qual ela decidiu não pedir as medidas ${ }^{80}$ protetivas de urgência que afastassem o marido do lar. Outro ponto que ela destaca

\footnotetext{
${ }^{80}$ A LMP pormenoriza e define as medidas protetivas de urgência. Cito: Seção II - Das Medidas Protetivas de Urgência que Obrigam o Agressor. Art. 22. Constatada a prática de violência doméstica e familiar contra a mulher, nos termos desta Lei, o juiz poderá aplicar, de imediato, ao agressor, em conjunto ou separadamente, as seguintes medidas protetivas de urgência, entre outras: I - suspensão da posse ou restrição do porte de armas, com comunicação ao órgão competente, nos termos da Lei no 10.826, de 22 de dezembro de 2003; II afastamento do lar, domicílio ou local de convivência com a ofendida; III - proibição de determinadas condutas, entre as quais: a) aproximação da ofendida, de seus familiares e das testemunhas, fixando o limite mínimo de distância entre estes e o agressor; b) contato com a ofendida, seus familiares e testemunhas por qualquer meio de comunicação; c) freqüentação de determinados lugares a fim de preservar a integridade física e psicológica da ofendida; IV - restrição ou suspensão de visitas aos dependentes menores, ouvida a equipe de atendimento multidisciplinar ou serviço similar; V - prestação de alimentos provisionais ou provisórios. § 1o As medidas referidas neste artigo não impedem a aplicação de outras previstas na legislação em vigor, sempre que a segurança da ofendida ou as circunstâncias o exigirem, devendo a providência ser comunicada ao Ministério Público. § $20 \mathrm{Na}$ hipótese de aplicação do inciso I, encontrando-se o agressor nas condições mencionadas no caput e incisos do art. 6 o da Lei no 10.826, de 22 de dezembro de 2003, o juiz comunicará ao respectivo órgão,
} 
é que se a justiça tivesse determinado medidas protetivas de afastamento e o companheiro saísse da casa em que moravam, ela continuaria convivendo com a família do marido. Além disso, ele ficaria impedido de visitar a casa em que os pais dele moravam. Um aspecto importante é que, após o episódio da delegacia, minha anfitriã e os filhos do casal deixaram a casa em que moravam e mudaram-se para a casa da mãe de Alice.

Cerca de três dias após ter sido agredida e ter ido à delegacia circunscricional próxima à sua residência, Alice, acompanhada da cunhada (que foi sua testemunha), foi à delegacia especializada em violência doméstica, localizada no Plano Piloto. Ela conta que decidiu procurar a Delegacia Especial de Atendimento à Mulher porque achou que não foi bem atendida na sua tentativa anterior.

Alice disse que ficou satisfeita com o atendimento recebido na delegacia especializada porque "lá o tratamento é diferente, é outra coisa". Ela conta que desta vez solicitou as medidas protetivas de urgência e, após o atendimento, foi encaminhada ao Instituto Médico Legal para realizar o exame de corpo de delito.

O relato de Alice possui semelhanças com o relato de Ana Clara, principalmente em relação ao tratamento que ambas receberam quando foram à delegacia. Embora Ana Clara tenha ido a uma delegacia e Alice tenha ido a outra delegacia, os atendimentos foram semelhantes, se pensarmos que ambas tiveram suas demandas deslegitimadas. É importante destacar que as duas foram a delegacias circunscricionais localizadas em regiões administrativas.

É importante destacar também que os atendimentos oferecidos são diferentes. E, nesse caso, às vezes a diferença de atendimento está relacionada à desconsideração e/ou desclassificação do conflito, o que pode contribuir com uma insatisfação com a LMP. Cito Pasinato (2015:534-535), que, a meu ver, pode contribuir com o tema:

Após oito anos de aprovação dessa legislação, tem-se observado que esses e outros avanços convivem com múltiplas resistências para sua implementação e aplicação. Diagnósticos e estudos realizados nesse período revelam que a aplicação da Lei está

\footnotetext{
corporação ou instituição as medidas protetivas de urgência concedidas e determinará a restrição do porte de armas, ficando o superior imediato do agressor responsável pelo cumprimento da determinação judicial, sob pena de incorrer nos crimes de prevaricação ou de desobediência, conforme o caso. § 3o Para garantir a efetividade das medidas protetivas de urgência, poderá o juiz requisitar, a qualquer momento, auxílio da força policial. § 4o Aplica-se às hipóteses previstas neste artigo, no que couber, o disposto no caput e nos $\S \S 5$ e e $6^{\circ}$ do art. 461 da Lei no 5.869, de 11 de janeiro de 1973 (Código de Processo Civil). Seção III - Das Medidas Protetivas de Urgência à Ofendida. Art. 23. Poderá o juiz, quando necessário, sem prejuízo de outras medidas: I - encaminhar a ofendida e seus dependentes a programa oficial ou comunitário de proteção ou de atendimento; II - determinar a recondução da ofendida e a de seus dependentes ao respectivo domicílio, após afastamento do agressor; III - determinar o afastamento da ofendida do lar, sem prejuízo dos direitos relativos a bens, guarda dos filhos e alimentos; IV - determinar a separação de corpos.
} 
restrita à esfera judicial criminal, onde ocorre, também, com dificuldades e limites. Paralelamente, as discussões a respeito das redes de serviços e suas interfaces com os temas da violência e gênero também vêm acumulando avanços. Dia após dia se fortalece o entendimento de que o sucesso da Lei está ameaçado pelas muitas falhas que se identificam em sua aplicação. Seja porque existem poucos serviços para o atendimento das mulheres ou porque não se responsabilizam os culpados, ou porque há insuficiente compromisso de governos para a articulação das redes intersetoriais, ou, ainda, pelas contingências de recursos humanos e a baixa especialização dos profissionais que têm contribuído para a permanência de atendimentos discriminatórios e prejudiciais às mulheres. Circunstâncias que resultam, ao fim e ao cabo, na não universalização do acesso à justiça e em direitos para mulheres que terminam, muitas vezes, com um boletim de ocorrência em uma das mãos e uma medida de proteção na outra, sem que, para além desses papéis, existam políticas que deem mais efetividade à sua proteção e condições para que saiam da situação de violência.

No entanto, como veremos a seguir, isso não significa que o atendimento realizado em delegacias circunscricionais se caracterize por não reconhecer demandas relacionadas à Lei Maria da Penha. Ao contrário disso, veremos situações em que minhas anfitriãs disseram que foi na delegacia que elas perceberam que a LMP "funcionava". A seguir, apresento o relato de Carolina.

\section{3 - Carolina - "A delegada falou para ele vir aqui e tirar tudo dele. Ele veio e tirou"}

Carolina me recebeu em seu apartamento, no Núcleo Bandeirante, após o término do seu expediente de trabalho em uma livraria localizada no Plano Piloto. Carolina me conta que começou a namorar o ex-marido aos 16 anos de idade, na cidade em que ambos nasceram, no interior de Sergipe.

Cerca de um ano depois, a mãe e o padrasto de Carolina mudaram-se para Brasília, em busca de novas e melhores oportunidades de emprego e ela veio com a família. A minha anfitriã relata que a mãe dela jamais gostou do genro, nunca aprovou a relação do casal e que a tentativa da família em separá-los foi um dos motivos que provocaram a mudança de Estado.

Após a mudança, o então namorado de Carolina decidiu vir para Brasília para que o relacionamento entre o casal continuasse e Carolina decidiu fugir de casa para morar com o namorado. O relacionamento entre o casal durou dezenove anos e terminou em 2013. Durante esse tempo, nasceram duas crianças que hoje são adolescentes de 18 e 13 anos, que moram com o pai e com a mãe, respectivamente.

Ela conta que foi em Brasília que os dois aprenderam uma profissão e, em vários momentos, quando o parceiro estava desempregado, era ela quem sustentava a casa. Segundo Carolina, após o ex-marido conseguir estabilidade na carreira de microempresário, ele não 
queria mais que ela trabalhasse. Após ter passado por algumas situações constrangedoras provocadas pelo ex-companheiro nos empregos que teve anteriormente, Carolina desistiu de trabalhar fora de casa.

Minha anfitriã diz que o ex-companheiro nunca a agrediu fisicamente, mas na relação era comum que ele a insultasse, humilhasse e a agredisse verbalmente. Em seu relato, ela destaca que o ex-marido a forçava a ter relações sexuais: "Ele não me respeitava, não respeitava a minha hora. Tinha que ser na hora que ele queria".

Minha anfitriã conta que a briga que motivou a separação e denúncia começou após ela ter descoberto que o marido havia sido infiel. Carolina relembra que o ex-companheiro estava dirigindo, mas ele parou o carro próximo a uma BR e começaram a discutir. Além do ex-casal, estavam no veículo dois familiares do ex-marido. Uma viatura da polícia militar estava fazendo ronda no local e os policiais presenciaram a briga do então casal que, naquele momento, trocavam gritos e acusações fora do carro. Todos foram levados para a delegacia. Eu perguntei para Carolina se ela já havia sofrido algum tipo de agressão anteriormente. Sobre esse aspecto, minha anfitriã relata:

Antes tinha agressão verbal, mas meu caso mesmo era mais psicológico. Humilhação. Mas não de bater. De bater não. Em casa era muita discussão, muita humilhação (...). As torturas que eu sofria, psicológicas, era pior. Eu preferia que ele me batesse do que me forçar a ter relações com ele sem a minha vontade. Ele não me respeitava, não respeitava a minha hora. Tinha que ser a hora que ele queria.

Um aspecto importante e que merece ser destacado é que Carolina foi atendida na mesma delegacia circunscricional que Alice, com diferença de pouco mais de um ano entre os dois atendimentos. Apesar dessa coincidência, a experiência que Carolina teve nesta delegacia foi absolutamente diferente da primeira experiência descrita por Alice.

Carolina relata que assim que chegou à delegacia, a delegada que estava no plantão foi atendê-la, que o atendimento foi rápido e que naquele momento aconteceu o que ela queria e esperava: o ex-companheiro seguiu as orientações da delegada e saiu da casa em que vivia com a família. É oportuno citar:

Foi bom. A delegada me aconselhou, falou que se não estava dando certo... E eu segui o conselho. Ela perguntou o que eu queria e eu disse que eu queria que tirasse ele de casa, que não queria ele mais aqui. (...) Eu fui atendida bem no dia da confusão pela delegada. Ela foi rápida. Eu não tenho do que reclamar. Aconteceu meio dia, antes das duas horas a gente já tava sendo atendidos na delegacia. Ela me ouviu, ouviu ele, perguntou o que eu queria... Eu disse que era que ele saísse de casa, aí ela foi lá e falou que era para ele vir no apartamento, tirar as coisas dele e ir lá assinar o papel. (...) A delegada falou para ele vir aqui e tirar tudo dele. Ele veio e tirou. 
Carolina considera que o primeiro atendimento que recebeu na delegacia circunscricional atendeu às suas expectativas. Segundo minha interlocutora, a delegada agiu rapidamente ao determinar que seu ex-companheiro deveria imediatamente deixar a residência do casal.

Minha anfitriã considera que essa ação alterou significativamente a realidade que ela vivia, já que, desde então, o casal nunca mais morou junto. Esse primeiro atendimento que Carolina recebeu gerou grandes expectativas na minha anfitriã. Ela conta que, como foi atendida de forma rápida e eficaz, supôs que todo o processo aconteceria de forma rápida e que ela teria todas suas demandas atendidas. Como veremos, isso não aconteceu. E ao ter suas expectativas negadas, Carolina se frustrou com o atendimento que recebeu do sistema de justiça e com a legislação que acionou.

Após a separação, Carolina descobriu que vários bens e imóveis que o casal havia comprado durante o casamento estavam no nome de terceiros ligados ao ex-marido, como parentes e amantes. Carolina conta que, quando já estavam separados, o ex-companheiro furtou cheques que ela assinava e deixava em casa, para fazer transações comerciais, o que acabou fazendo com que o nome dela fosse negativado em Serviços de Proteção ao Crédito.

Contudo, Carolina não possui provas materiais que a ajude a fundamentar essas acusações. Esse é um dos pontos que contribui para que minha interlocutora se sinta desamparada: ela simplesmente não consegue levar essas demandas à Justiça. O sentimento de que seu ex-companheiro praticou ações que a prejudicaram de diversas formas durante e após o relacionamento, e mesmo assim permanece impune, permeou a nossa conversa.

Em sua fala, Carolina chama atenção para as diversas formas de violência que viveu durante e após a separação. Minha anfitriã relata que, apesar de ela nunca ter passado por situações de violência física, passou por situações que poderiam ser entendidas, segundo a legislação ${ }^{81}$, como tipos de violência psicológica, violência sexual, violência patrimonial e violência moral.

\footnotetext{
${ }^{81}$ Capítulo II - Das formas de violência contra doméstica e familiar contra a mulher. Art. $7^{\circ}$ São formas de violência doméstica e familiar contra a mulher, entre outras: I - a violência física, entendida como qualquer conduta que ofenda sua integridade ou saúde corporal; II - a violência psicológica, entendida como qualquer conduta que lhe cause dano emocional e diminuição da autoestima ou que lhe prejudique e perturbe o pleno desenvolvimento ou que vise degradar ou controlar suas ações, comportamentos, crenças e decisões, mediante ameaça, constrangimento, humilhação, manipulação, isolamento, vigilância constante, perseguição contumaz, insulto, chantagem, ridicularização, exploração e limitação do direito de ir e vir ou qualquer outro meio que lhe cause prejuízo à saúde psicológica e à autodeterminação; III - a violência sexual, entendida como qualquer conduta que a constranja a presenciar, a manter ou a participar de relação sexual não desejada, mediante intimidação, ameaça, coação ou uso da força; que a induza a comercializar ou a utilizar, de qualquer modo, a sua sexualidade, que a impeça de usar qualquer método contraceptivo ou que a force ao matrimônio, à gravidez, ao
} 
Segundo minha anfitriã, após a separação, o ex-companheiro a ameaçou, insultou e chegou a fazer uma cópia da chave do apartamento em que viviam para poder entrar livremente no local, com o intuito de amedrontá-la. Carolina conta que procurou outra delegacia circunscricional, localizada perto da sua residência, no Núcleo Bandeirante, algumas vezes. Seu intuito era denunciar novamente o ex-marido:

Depois disso, eu fui umas três vezes até à delegacia. Ele chegou a subir aqui no apartamento, como se morasse aqui. Falava alto, dava murro no guarda-roupa... Aí eu fui até à delegacia falar que meu ex-marido estava aqui e ninguém fez nada. Ninguém chegou a vir aqui atrás dele.

Durante a entrevista, minha anfitriã expressa o sofrimento pelo qual passou ao vivenciar situações de violência, mesmo após a separação. Mas, Carolina é enfática ao dizer que considera satisfatório apenas o primeiro atendimento que recebeu, quando a delegada ordenou que o então marido da minha anfitriã saísse de casa.

Carolina obteve atendimentos muito diferentes. Na primeira vez que foi à delegacia, ela disse que suas demandas foram contempladas, contudo, isto não nas outras vezes. Nas outras vezes em que foi à delegacia, as agressões e insultos que recebeu do ex-marido não foram tratados com a consideração que Carolina esperava ${ }^{82}$. Esta situação nos ajuda a refletir sobre o tipo de atendimento que é oferecido às mulheres em situação de violência quando estas vão a delegacias para acionar a LMP e sobre o atendimento em relação a violências que não se enquadram no conceito de violência física.

Isadora Vier Machado e Miriam Pillar Grossi (2015), falam sobre a complexidade presente no conceito de violência psicológica da Lei Maria da Penha. Segundo Machado e Grossi (2015:562), violências psicológicas são condutas que, em termos específicos, provocam dano emocional, diminuição da autoestima, prejuízo ao pleno desenvolvimento, degradação ou controle.

De acordo com as autoras, "os meios ou estratégias que podem conduzir a esse dano (...) compreendem as seguintes condutas: ameaça, constrangimento, humilhação,

\footnotetext{
aborto ou à prostituição, mediante coação, chantagem, suborno ou manipulação; ou que limite ou anule o exercício de seus direitos sexuais e reprodutivos; IV - a violência patrimonial, entendida como qualquer conduta que configure retenção, subtração, destruição parcial ou total de seus objetos, instrumentos de trabalho, documentos pessoais, bens, valores e direitos ou recursos econômicos, incluindo os destinados a satisfazer suas necessidades; V - a violência moral, entendida como qualquer conduta que configure calúnia, difamação ou injúria.

${ }^{82}$ Chama atenção que estava em vigor medidas protetivas de urgência que obrigavam o ex-companheiro de Carolina a se manter afastado, quando este invadiu o apartamento. Quando eu questiono porque ela não ligou para a polícia, ela me surpreende e diz que foi pessoalmente à delegacia, mas que nada aconteceu. No próximo
} 
manipulação, isolamento, vigilância constante, perseguição contumaz, insulto, chantagem, ridicularização, exploração e limitação do direito de ir e vir" (idem). Segundo Machado e Grossi, é fundamental refletir sobre este conceito no processo de implementação da LMP:

\begin{abstract}
Em particular, no caso das violências psicológicas, há uma evidente complexidade conceitual que motivou a busca das vias pelas quais têm sido instrumentalizadas. Ao compreender como o conceito é vivenciado e operacionalizado, abre-se uma via para comprovar que a discussão teórica a respeito do mesmo é fundamental no processo de implementação da Lei Maria da Penha. Primeiramente, por dar meios para aperfeiçoar as estratégias extrajurídicas que o diploma legal esboça. Em segundo lugar, porque resume muitos elementos da história da Lei Maria da Penha que atribuem sentido às escolhas feitas pelas instâncias envolvidas em sua elaboração (2015:570)
\end{abstract}

Segundo Machado e Grossi (2015:570) “é possível notar que este elemento, por si só, não modificou amplamente as práticas das/os agentes de segurança e justiça, já que a lei penal segue sendo a base tipológica que motiva a atuação dessas/es profissionais". Para essas autoras, há uma aceitação maior ao conceito de violência psicológica nas delegacias cujo atendimento é voltado especificamente para mulheres. Mas, ao que parece, a descrição desta forma específica de violência não modificou totalmente o atendimento oferecido nas delegacias.

Contudo, o assunto é muito mais complexo do que inicialmente possa parecer. Compreendo, como Machado e Grossi, que as delegacias especializadas possuem um melhor aparato para lidar com situações de violência contra mulheres. Neste sentido, é oportuno destacar o atendimento recebido por Alice, sobre o qual falei anteriormente.

Alice conta que quando foi denunciar o companheiro na delegacia circunscricional próxima a sua casa, o delegado concordou com a justificativa do marido para a agressão. Quando Alice foi à DEAM, o atendimento que ela recebeu foi totalmente diferente e, naquele local, ela disse que suas demandas foram reconhecidas e foi tratada com respeito e consideração. Porém, isso não significa que esse espaço consiga atender a todas as demandas das mulheres que vão até lá.

\title{
3.4 - Lygia - "Eu pensava que... Eu ia chamar a polícia e ele ia ser preso"
}

Lygia tem por volta de 20 anos de idade, é casada e mãe de uma criança. À época da entrevista, Lygia estava grávida de seis meses e fez uma escolha diferente das minhas

capítulo, abordarei esse aspecto e as percepções das minhas anfitriãs sobre a LMP e o sistema de justiça criminal. 
anfitriãs. Ao invés de me encontrar em sua residência ou no seu trabalho, Lygia escolheu me encontrar próximo ao local em que faria exames e a consulta de acompanhamento do prénatal. Minha interlocutora conta que conheceu o parceiro há muitos anos, já que os dois sempre moraram próximos um ao outro. Lygia conta que começou a se relacionar com o parceiro quando tinha por volta de 15 anos de idade e o companheiro tinha 29 anos. Segundo minha anfitriã, ela sempre foi apaixonada pelo atual parceiro, mas começaram a se envolver após ele ter se separado da primeira esposa.

A família de Lygia foi terminantemente contra o relacionamento, pelo fato de o companheiro de Lygia já ter um filho e, principalmente, pela grande diferença de idade entre os dois. Embora a família da minha interlocutora proibisse o relacionamento, ela e o atual marido mantiveram encontros escondidos ao longo de um ano.

Os pais de Lygia descobriram o relacionamento após ela ter reprovado no colégio devido ao excesso de faltas que cometia para poder se encontrar com o então namorado. Lygia conta que, após esse episódio, os pais tiveram que aceitar a relação, embora nunca tenham concordado com a opção feita pela filha. Após esse primeiro ano de relacionamento, o namorado convidou Lygia para ir morar com ele na casa em que ele já residia com o filho.

Minha anfitriã conta que desde o início do relacionamento ela passou por diversas situações de violência e que o companheiro já utilizou vários instrumentos, tais como facas, arma de fogo, pedaços de madeira etc. para intimidá-la. Lygia lembra que, em 2007, quando ela estava grávida do seu primeiro filho, o casal teve uma discussão e ela apanhou dele. Os responsáveis por Lygia, à época menor de idade, souberam do ocorrido. Lygia conta que, naquela época, as famílias ainda eram amigas e após os pais da minha anfitriã terem conversado com o pai do agressor, optaram por não processar criminalmente o companheiro da filha e não informar o fato às autoridades competentes. Após esse episódio, o casal se separou por alguns meses, mas reataram o relacionamento após a criança ter nascido.

Ao longo dos anos, minha anfitriã conta que continuou passando por várias situações violentas no relacionamento com o companheiro, mas que nesse período ela acreditava que o companheiro mudaria de comportamento. Ele não permitia que Lygia mantivesse amizades, que saísse sem informar qual era o seu destino, companhia e a que horas iria chegar e nunca gostou que ela trabalhasse fora de casa.

Ela conta que o marido tinha ciúmes até mesmo de amigos que ela fazia na escola, mas que, apesar disso, concluiu o Ensino Médio. Lygia relata que o marido a proibia de tomar anticoncepcionais e que a forçava a ter relações sexuais para que assim ela "provasse" que não estava se relacionando com outros homens. 
Minha anfitriã também relata que ficava muito abalada com fatos que o marido espalhava sobre ela: "O que mexia muito comigo, na verdade, também era o psicológico. As calúnias, as coisas que ele falava que eu estava fazendo e que eu nunca fiz”. Segundo Lygia, os familiares do casal sabiam do que acontecia e os pais dela sempre a incentivaram a "abandonar o relacionamento e voltar para casa".

Eu perguntei se outras pessoas sabiam das situações que ela vivenciava em casa e Lygia me disse que a família dela, a família do marido e amigos do marido sabiam que ela era agredida e ameaçada pelo companheiro. Ela contou que, no passado, as pessoas intervinham, principalmente quando as brigas aconteciam em público. Como o casal sempre reaparecia junto e se reconciliava, Lygia diz que as pessoas pararam de falar sobre o assunto. A exceção é uma tia do companheiro de Lygia que, segundo ela, sempre a defende do sobrinho: "mas as outras pessoas não. Eu acho que eles não se metem mais porque pensam 'eu vou me meter e amanhã eles estão juntos'".

O fato que gerou o processo aconteceu em meados de 2013, em um domingo à noite. O marido de Lygia começou a discussão insinuando que ela tinha um amante, após ela ter recebido a ligação de um colega de trabalho. Após a ligação, o marido começou a agredi-la verbalmente e a ameaçá-la com uma faca. Durante a discussão, familiares do marido apareceram e Lygia conseguiu fugir para a casa deles, local em que passou a noite.

Minha anfitriã conta que, pela manhã, ela voltou para a casa em que morava com o marido e com o filho para pegar roupas para trabalhar. O companheiro da minha anfitriã voltou a ameaçá-la e tentou agredi-la com puxões de cabelo e pontapés. Ele disse que se Lygia saísse de casa, ela ficaria sem ver o filho, sem poder pegar objetos pessoais e a ameaçou: "Se você for embora você vai ver se vai ficar viva". Porém, Lygia conseguiu sair de casa e chamar a polícia.

Lygia conta que decidiu chamar a polícia porque além de estar cansada de conviver com toda aquela situação, estava com medo da ameaça que o companheiro fez de que ela não poderia mais ver o filho. Minha anfitriã conhecia a Lei Maria da Penha, mas achava que a legislação era "só para agressão física". Sobre esse aspecto é importante destacar que minha anfitriã só soube que a lei previa diferentes formas de violência no atendimento que teve com a equipe de atendimento multidisciplinar do Juizado.

Ela conta que foi no Fórum que "me explicaram que eu estava sendo agredida psicologicamente também, que as coisas que ele me falava... Eu achei que as coisas que ele me falava não iam dar em nada, não ia contar nada, só as agressões físicas mesmo. Aí ele me explicou o que era injúria, calúnia, difamação". 
Voltando ao momento em que Lygia resolveu ligar para a polícia, ela conta que tinha expectativas de que, denunciando o companheiro, sua vida poderia mudar. Sobre esse aspecto, cito a fala da minha interlocutora:

\begin{abstract}
Eu pensava que... Eu ia chamar a polícia e ele ia ser preso. Tanto que quando eu chamei a polícia lá, quando ele falou (o PM) que não podia fazer nada... Eles têm que pegar a pessoa batendo? Só se for, né. Porque é só se for em flagrante e ele não pode se meter em briga de marido e mulher. Tipo, não pode fazer nada... "Se a senhora quiser que a gente te leve na delegacia...". Bom, você fica desamparada. Desamparada. Porque ele tinha me agredido, os vizinhos tinham escutado, tinha aquilo tudo de testemunha e não fazer nada... Aí eles também fizeram pouco caso disso. Eu achava que era assim, que era mais rápido, que era uma coisa certa... Porque uma pessoa te ameaçar... Eles falaram que não poderiam fazer nada, que não foi em flagrante, que não poderiam se meter... E todo mundo na rua que escutou ele gritando e eles não fizeram nada. Eu falei:- Então tá bom. Aí me perguntaram se eu queria ir até a delegacia, eu falei que não.
\end{abstract}

Após essa cena, Lygia foi para o local em que trabalhava. Minha anfitriã diz que, naquele dia, chegou bastante alterada ao seu trabalho, por conta de todos os acontecimentos que tinha vivenciado. Apesar de já ter sido ameaçada outras vezes, ser impedida de se aproximar do filho do casal a deixou consternada. Quando Lygia contou para as colegas de trabalho o que havia acontecido, todas as colegas a incentivaram a ir até a delegacia, inclusive o seu chefe, que a dispensou para que ela pudesse registrar o boletim de ocorrência. Lygia disse que as colegas de trabalho a incentivaram a denunciar novamente e ela pensou que "talvez assim, com a justiça e com a polícia, ele me deixasse em paz".

Minha anfitriã optou por registrar o BO na DEAM, localizada no Plano Piloto. Ela conta que a delegacia estava cheia e que no período em que esperava ser atendida conheceu uma moça que "teve que sair de casa porque o cara batia nela e ela saiu de lá sem ser atendida, por causa da demora". Lygia conta que essa moça desistiu de ser atendida por conta do longo tempo de espera, já que a delegacia estava cheia naquela segunda-feira.

Minha interlocutora diz que, quando foi à delegacia, não havia nenhuma marca ou hematoma aparente no seu corpo decorrente das agressões que recebeu do marido. Ela me explica que, naquele dia, "ele me chutou, puxou meu cabelo... Assim não deixava marcas, mas eu sei que se fizesse alguma coisa eles iam saber porque estava tudo doendo, se eu fosse fazer algum exame".

Lygia disse que, enquanto esperava para ser atendida, chegaram à delegacia outras mulheres, cujos hematomas eram aparentes. "Chegava muitos casos lá e... Eu acho que eles davam prioridade para a visão, sabe? Para o quê eles viam. Então chegou uma mulher lá com dois olhos roxos, aí ela foi logo atendida. Essas que estavam com hematoma feio mesmo, eles adiantavam lá”. 
Ela conta que, quando foi atendida, relatou o que havia acontecido no boletim de ocorrências e a pessoa que a atendeu disse que ela seria chamada no Fórum e que teria que comparecer às audiências. Depois desse atendimento, Lygia disse que foi encaminhada para conversar com algumas pessoas que estavam trabalhando na delegacia - que ela acha que eram "estagiários da psicologia". Quando saiu da delegacia, minha anfitriã voltou para o trabalho.

Após o expediente, Lygia voltou à casa que dividia com o marido e ele "deixou" que ela levasse o filho do casal. Porém, o marido não permitiu que ela pegasse quaisquer objetos pessoais ou roupas dela que estivessem na casa que o casal vivia. Lygia foi com a criança para a casa dos pais e me conta que ficou cerca de um mês com pouquíssimas roupas e pertences pessoais.

A versão de Lygia sobre o atendimento que ela acessou quando ligou para a polícia e, posteriormente, foi a DEAM, traz novos pontos de análise para este trabalho. Lygia chama atenção para as expectativas que possuía quando ligou para a polícia. Naquele momento, ela chamou a polícia porque "queria que ele fosse preso". Mas, pelo que pude compreender, essa não foi uma decisão sobre a qual ela pensou apenas naquele momento, pois minha anfitriã já “estava cansada" de viver situações como aquela.

Quando o policial militar chegou ao local, Lygia foi surpreendida ao descobrir que, para que o marido fosse detido, ele deveria ter sido pego em flagrante. O policial explicou para Lygia que o procedimento, nestas situações, é que ela vá até a delegacia e registre ocorrência contra o companheiro. Ela se sentiu "desamparada" porque, apesar de também ter sido agredida em local público, na frente de várias pessoas, a legislação prevê procedimentos específicos que, naquele caso, não atendiam às expectativas que Lygia esperava.

No trabalho, Lygia conversou com colegas sobre aquela situação e foi incentivada a registrar BO contra o companheiro. Ao chegar à delegacia, relata que, devido ao seu caso não transparecer tanta gravidade quanto outros casos, ela teve que esperar enquanto outras mulheres, cujas agressões eram visíveis, passaram à sua frente. Aqui, ela chama atenção para a "materialidade" e "concretude" da agressão. O fato de as agressões que ela sofreu não terem deixado marcas aparentes em seu corpo, segundo o ponto de vista da minha anfitriã, contribuíram para que ela fosse atendida de forma menos eficiente do que outras mulheres que também foram à delegacia naquele período. Lygia chama atenção para o caso de uma moça que desistiu do atendimento devido a demora. Por fim, minha anfitriã fala que o atendimento foi "rápido" e que, após o atendimento, ela foi encaminhada para conversar com "estagiários da psicologia". 
Ao longo do seu relato, Lygia destaca as várias vezes em que se frustrou com o atendimento que recebeu do sistema de justiça. Inicialmente, por ter expectativas em relação a LMP que não foram atendidas porque a legislação previa procedimento diferente do que ela esperava. $\mathrm{O}$ atendimento que Lygia recebeu quando foi à delegacia pode ser interpretado como uma situação em que não houve reconhecimento das suas demandas. Aqui, minha interlocutora destaca que mulheres cujos casos envolviam agressões físicas visíveis em seus corpos eram atendidas rapidamente e, de certa forma, ela se sentiu insultada com o tratamento ao qual teve acesso. Sobre este aspecto, cito Cardoso de Oliveira (2010:461):

\begin{abstract}
O reconhecimento, ou o direito de ser tratado com respeito e consideração, é o aspecto que melhor expressaria a dimensão moral dos direitos, e as demandas a ele associadas traduzem (grande) insatisfação com a qualidade do elo ou relação entre as partes, vivida como uma imposição do agressor e sofrida como um ato de desonra ou de humilhação (Cardoso de Oliveira, 2004 e 2008b). Nos casos em que a reparação a este tipo de ofensa é suficientemente embutida nas deliberações judiciais sobre as outras duas dimensões temáticas dos conflitos (direitos e interesses), os tribunais promovem um desfecho satisfatório para as respectivas causas. Entretanto, nas causas em que este tipo de ofensa -que tenho caracterizado como insulto moral -ganha precedência ou certa autonomia nos processos não há reparação adequada e o desfecho judicial é frequentemente insatisfatório do ponto de vista das partes (Cardoso de Oliveira, 2002, 2004, 2008b).
\end{abstract}

O conceito produzido por Cardoso de Oliveira nos auxilia a compreender ofensas que nem sempre conseguem ser traduzidas em evidências materiais e, dessa forma, não são inseridas no processo. Aqui, minha anfitriã se sentiu desvalorizada e achou que as suas demandas não foram atendidas pelo sistema de justiça.

É fundamental termos em vista que as percepções que Lygia produziu sobre o atendimento que recebeu são importantes para compreendermos o ponto de vista dela sobre o sistema de justiça e sobre a LMP. Como veremos no próximo capítulo, Lygia sentiu que seu caso não foi tratado com a consideração que devia, que ela não teve suas demandas reconhecidas e relata a sua frustração com as várias etapas do processo.

Outro caso que se relaciona com o de Lygia é o da minha interlocutora Lia. Em seu relato, Lia fala sobre como o sistema de justiça não conseguia atender suas demandas e para que a situação de violência pela qual ela passava acabasse, foi necessário que Lia utilizasse mecanismos que não estavam previstos na legislação.

\title{
3.5 - Lia - "Mas parece que você gosta de apanhar, né? Você deve gostar, porque não é possível. A gente tem mais o que fazer, a gente trabalha!"
}


Lia escolheu me receber na casa em que morava com a família. $\mathrm{Na}$ época da entrevista, ela tinha por volta de 40 anos de idade, trabalhava como auxiliar de serviços gerais e não tinha concluído a Educação Básica. Minha anfitriã é mãe de duas crianças de relacionamentos diferentes. Ao conversar comigo, Lia pediu para que não conversássemos sobre as situações que ela viveu durante o relacionamento que gerou a sua filha mais velha. Ela escolheu falar apenas suas percepções e lembranças referentes ao relacionamento do qual nasceu seu segundo filho. Foi através dos dados contidos no processo referente a esse segundo relacionamento que eu consegui contatar Lia.

Ela conta que conheceu o ex-companheiro, pai do seu segundo filho, em 2009, em um bar na Candangolândia e que o casal namorou por cerca de doze meses até que ela descobriu que estava grávida. Durante a gravidez, o relacionamento continuou, no entanto, o casal morava em residências diferentes. Segundo Lia, uma das opções mais frequentes de lazer do ex-casal era frequentar bares, principalmente aos finais de semana. Ela conta que era comum, nessas ocasiões, ambos se tornarem mais agressivos e, na época em que namoravam, já aconteciam muitas brigas com ofensas e que "de vez e quando aconteciam puxões de cabelo. Ele já tinha um jeito de ser agressivo mesmo". Nessas ocasiões, embora ela tentasse revidar, conta que sempre ficava em desvantagem.

Minha interlocutora conta que, no início do relacionamento até o momento em que a criança tinha cinco meses, Lia morava na casa da sua mãe e o companheiro também morava com a família. Durante esse período, ela conta que se sentia só porque havia momentos em que o companheiro sumia sem avisá-la e, nas ocasiões em que ela tentou cobrá-lo, o casal discutiu e ela foi agredida com tapas e puxões de cabelo.

Um momento importante foi quando o companheiro a visitou, na casa em que Lia morava com a mãe, no período em que ela estava de resguardo por ter sido submetida a uma cirurgia cesárea. Lia conta que pegou o celular do companheiro para saber quem havia ligado para ele e, quando ele percebeu, tomou o aparelho da mão dela e a atingiu com um murro no ombro. A mãe de Lia presenciou a agressão, expulsou o genro do local e o proibiu de entrar novamente na casa. Lia diz que outros familiares viram seu corpo machucado e que "todo mundo ficou muito revoltado".

Alguns meses após este episódio, Lia decidiu sair de casa, para ir morar com o pai do seu filho. Ela conta que tomou essa decisão porque havia perdoado o ex-companheiro e por acreditar que era importante que o filho do casal crescesse em contato com o pai e, como o ex-companheiro estava proibido de frequentar a casa em que ela morava, ela achou melhor se 
mudar e ir morar com ele. Foi então que Lia e o ex-parceiro alugaram um apartamento para a família morar.

Ela diz que saiu de casa para morar com o companheiro contra a vontade dos familiares, principalmente da sua mãe, que se mostrava preocupada e dizia que "alguma coisa poderia acontecer". Minha anfitriã relata que, depois que ela resolveu dar uma nova chance ao seu atual ex-companheiro, e ir morar com ele após o nascimento da criança, sua mãe lhe disse que "não estava mais nem aí". Nessa época, ela parou de receber incentivo dos familiares para denunciar o ex-marido, porque quando ela tocava no assunto eles sempre lembravam que as agressões já haviam acontecido outras vezes e que Lia sempre perdoava o companheiro e continuava o relacionamento.

Minha anfitriã relata que, após a sua mudança, aconteceram outras "agressões verbais", mas a situação que motivou a denúncia só ocorreu após alguns meses em que o casal já morava junto. O casal e o bebê, que à época ainda não tinha completado um ano de vida, estavam voltando de uma festa infantil. O ex-companheiro de Lia estava alcoolizado e o casal estava discutindo quando o ex-marido guiou o carro para um terreno baldio, próximo à Candangolândia e ao Núcleo Bandeirante.

Ao chegarem, o ex-marido forçou Lia a descer do veículo e a ameaçou com uma faca $^{83}$. Lia conta que o ex-companheiro disse que "iria me matar de qualquer jeito, me deixar ali e que ia demorar muito tempo até a minha família me encontrar, que até eles me acharem eu não ia nem existir mais". Minha anfitriã conta esse caso muito emocionada e diz que, naquele momento, implorou pela sua vida e pediu para que ele não deixasse o bebê do casal sem mãe.

O ex-companheiro desistiu e levou Lia até uma rua próxima a casa em que a família dela morava. Ele a expulsou do carro e começou a agredi-la com mordidas, pontapés, tapas e murros. Após as agressões, o ex-parceiro ligou o carro e partiu com o bebê. Lia terminou o percurso até a casa da mãe a pé.

No dia seguinte, após ter sido agredida pelo companheiro, ela saiu da casa da sua mãe em direção à delegacia circunscricional que atendia à região em que Lia morava. Minha anfitriã diz que, em seu ponto de vista, o atendimento foi rápido e eficiente e que, assim que chegou, ela conseguiu registrar o boletim de ocorrência. Sobre esse processo:

Lia: - Quando eu cheguei lá contei todos os fatos que tinham acontecido, como é que foi, fiz a ocorrência, me deram o papel do IML. Fui para o IML. Fiz o laudo,

\footnotetext{
${ }^{83}$ Lia conta que o ex-companheiro colecionava diferentes tipos de facas e punhais e que sempre havia algum exemplar desses objetos em seu carro.
} 
tirei foto, esperei. Eu voltei para casa ainda. Voltei para casa. Voltei para casa. Por causa do meu filhinho, né!? Krislane: - Para a sua casa? Para a casa que você e seu companheiro moravam? Lia: - Voltei. Fiz a ocorrência e voltei para casa. Pedi medida protetiva para o juiz. O juiz pediu que ele saísse. Aí me deu a medida protetiva e foi quando ele saiu pela primeira vez...

Minha interlocutora relata que pouquíssimo tempo após ter ido à delegacia ("questão de pouquíssimos dias", segundo Lia), ela conseguiu o deferimento das medidas protetivas de afastamento contra o companheiro. Lia fala que mesmo separados, o seu ex-companheiro ia à casa em que haviam morado para visitar a criança. Em uma dessas visitas, eles conversaram e resolveram reatar o relacionamento "porque toda vez que ele me batia, passava um tempo e a gente voltava. Ficava tudo bom mais ou menos um mês e mais algumas semanas e voltava tudo de novo. Aí eram aqueles mesmos palavrões, aquelas mesmas agressões... Mesmas coisas" $"$.

Minha anfitriã diz que aquela foi a primeira vez que ela denunciou seu ex-parceiro, mas que não foi a última e que todas os boletins de ocorrência foram registrados durante o tempo em que permaneceram morando juntos. Nesse momento, Lia me surpreendeu ao revelar que ainda guarda todas as ocorrências, desde a primeira vez que denunciou o seu excompanheiro, em 2010.

Após a primeira denúncia, Lia me diz que sempre que o companheiro a agredia, ela ia até a delegacia, pois esperava que "ele fosse punido, de alguma forma". Foram várias idas à delegacia após a primeira denúncia. Ela fala que, em determinado momento, passou a ter vergonha de ir até à delegacia registrar novos boletins de ocorrência, porque ela passou a ser reconhecida naquele ambiente. Sobre esse aspecto, é oportuno citar:

Lia: - Eu já estava era com vergonha, sabe? De estar toda hora na delegacia. Krislane: - O pessoal na delegacia te cobrava alguma coisa? Lia: - Claro! Me cobravam! "Eu acho que você gosta de apanhar dele", eles falavam. - Krislane: Eles falavam assim para você? Lia: - É. Porque eu ia e depois eu tirava. Quantas ocorrências tinha lá que eu tinha tirado? Krislane: - E quem falava assim? Lia: Era homem, mulher, delegado... - Os coisa... Aqueles que ficam escrevendo lá. Krislane: - Escrivão? Lia: - Sim. "Mas parece que você gosta de apanhar, né? Você deve gostar, porque não é possível. A gente tem mais o que fazer, a gente trabalha". Mas eles falam esse tipo de coisa mesmo, quando você fica indo muito. Por isso que eu já tinha era vergonha de ir lá. Eu pensava: “Ah, não vou mais não".

Eu perguntei se Lia respondia a esse tipo de questionamento e ela me disse que não respondia, mas que se sentia muito envergonhada: "Mas era verdade mesmo, então o que eu

\footnotetext{
${ }^{84}$ Após contar esta situação, Lia me surpreendeu ao contar que aquela foi a primeira vez que ela denunciou o seu segundo marido, mas que ela conhecia e Lei Maria da Penha e, inclusive, denunciou seu ex-companheiro, pai da sua primeira filha. Quando eu me mostrei interessada e a questionei sobre essa situação Lia foi veemente ao dizer que não gostaria de conversar comigo sobre este fato.
} 
queria? Eu ia lá, denunciava... eles ficavam um tempão fazendo processo, tal e tal e tal para depois eu ir lá e não dar em nada. Aí né, poxa”. Eu questiono sobre quando Lia começou a receber esse tipo de tratamento na delegacia e ela me disse que não se lembra exatamente, mas que acha que passou a acontecer após a terceira denúncia:

Depois da primeira vez, todas as vezes eu ia. Eu cheguei a fazer por volta de cinco ocorrências contra ele. Só que aí depois a gente voltava, passava um tempo, ficava tudo bem e começava de novo. Aí eu ia de novo. Mas aí a gente tinha audiência e tudo. Ele sempre pedia para eu não ir nas audiências, mas eu sempre ia nas audiências. Mas, mesmo assim, não deu nada assim para ele. Ele não foi penalizado de nenhuma forma. Isso que eu fiquei meio assim... Mas só que eu também retirei as ocorrências que eu mesma fiz contra ele...

Em seu artigo “Existe violência sem agressão moral?” (2008), Cardoso de Oliveira analisa situações que envolvem disputas que foram levadas ao Judiciário. Contudo, o sistema de justiça não conseguiu solucionar esses conflitos porque não conseguiu atender a determinadas demandas. Nas palavras do autor: "a dimensão moral dos direitos é totalmente descartada de qualquer avaliação, e relações entre pessoas, portadoras de identidade, são pensadas como relações entre coisas ou autômatos com interesses e direitos prescritos, mas sem sentimentos, autonomia ou criatividade" (p. 141).

Cardoso de Oliveira (2008) explora neste trabalho a ideia de "querelante contumaz" que muito se relaciona com a trajetória de Lia. Segundo o autor, existe uma dificuldade característica de tribunais ou de instituições cuja lógica está voltada para o direito positivo em lidar com direitos associados à dimensão moral das disputas (p.141). Cardoso de Oliveira apresenta a discussão e dados referentes ao "querelante contumaz". Os dados apresentados por Cardoso de Oliveira indicam a dificuldade do sistema de justiça em lidar com o insulto e, consequentemente, com as demandas trazidas por essas pessoas.

Evidentemente Lia não "gostava de apanhar", como sugeriu um dos servidores que trabalhava na delegacia. Contudo, o sistema de justiça não tinha instrumentos para lidar com as demandas trazidas por Lia. Minha anfitriã conta que, diversas vezes, ela registrava ocorrência contra o companheiro, mas que o casal não se separava definitivamente. Após períodos em que ficavam afastados, Lia e o companheiro voltavam a se relacionar e minha anfitriã passava por novas situações de violência, em que era agredida pelo companheiro.

Como Lia não agia da forma que os servidores da delegacia julgavam a mais adequada, eles passaram a desconsiderar as suas demandas. Minha anfitriã relata que, depois de um tempo, ela deixou de ir à delegacia quando era agredida pelo seu companheiro porque passou a sentir "vergonha de ir lá". Neste caso, os questionamentos efetuados pelos servidores 
do sistema de justiça contribuíram para que Lia se afastasse do atendimento previsto na legislação.

Essa situação também contribui para refletirmos sobre até que ponto o sistema de justiça está preparado para receber demandas tão complexas quanto a proposta por Lia. Ainda sobre Cardoso de Oliveira, apresento trecho em que o autor fala sobre o "querelante contumaz", e que pode nos ajudar a refletir sobre esta situação:

Mais do que uma dimensão paranoica, os reclamantes persistentes chamam a atenção para as dificuldades das instituições judiciárias ou congêneres em lidar com o insulto, assim como para o significado social desse tipo de agressão (CARDOSO DE OLIVEIRA, 2008:143).

Este é um caso complexo porque, inicialmente ${ }^{\mathbf{8 5}}$, o que ela queria não era se separar do seu companheiro. O objetivo dela, ao acionar a legislação, era fazer com que o companheiro parasse de agredi-la. Lia buscava o direito de viver uma vida sem violência e o atendimento que foi oferecido a ela não necessariamente mostrou sensibilidade para com esta demanda.

Lia conta que a relação acabou quando, após uma briga, o ex-companheiro de Lia a expulsou de casa argumentando que era ele quem pagava as contas e o aluguel. Nesse dia, o ex-parceiro colocou todos os objetos pessoais de Lia, incluindo documentos, em sacos de lixo e jogou tudo fora. Após essa ocasião, Lia decidiu ir embora e saiu do Distrito Federal por um tempo.

Um aspecto importante que perpassa todos os casos relatados nesta pesquisa e, especialmente, os casos relatados por interlocutoras como Ana Clara, Alice, Lygia, Lia etc. é a diversidade de tratamento recebido pelas minhas anfitriãs quando essas procuraram as delegacias. O modo como o atendimento a mulheres em situação de violência doméstica no DF é feito, pode nos ajudar a compreender essa diversidade.

Azevedo et all (2013:31) revelam que no DF o atendimento policial a mulheres em situação de violência é realizado por uma Delegacia Especializada de Atendimento à Mulher (DEAM) e por trinta e uma Seções de Atendimento à Mulher (SAM) que estão presentes em

\footnotetext{
${ }^{85}$ É importante termos em mente que essa era a demanda inicial de Lia. O que ela buscava ao acionar a LMP era que o seu companheiro parasse de agredi-la, mas não necessariamente que o casal se separasse. Esse é um aspecto importante porque está relacionado diretamente ao fato de Lia ter procurado cinco vezes a delegacia para registrar BO contra o parceiro e, após algum tempo, o casal ter voltado a se relacionar. Com o passar do tempo, Lia percebeu que não queria mais se relacionar com o então parceiro. Dessa forma, as suas demandas em relação ao sistema de justiça mudaram. Nessa época ela não queria mais que o sistema de justiça "transformasse" o comportamento do companheiro para que eles pudessem se relacionar sem que ela fosse agredida. Aqui, ela queria que eles se afastassem e não mantivessem mais contato.
} 
delegacias circunscricionais. Segundo os autores, o fato de haver seções de atendimento a mulheres em todas as delegacias circunscricionais é importante porque oferece o serviço policial a mulheres que nem sempre tem condições de ir ao Plano Piloto para utilizar os serviços oferecidos pela DEAM.

As SAMs vinculam-se às delegacias em que se encontram sob competência do Departamento de Polícia Circunscricional, enquanto a DEAM é órgão pertencente ao Departamento de Polícia Especializada. Segundo os autores, essa configuração resulta em muitas diferenças no "nível de treinamento das equipes, nas rotinas de atendimento, bem como no tipo de interação com outros atores institucionais que lidam com mulheres em situação de violência doméstica”. É oportuno citar:

Tal configuração resulta em sensíveis diferenças, como veremos abaixo, no nível de treinamento das equipes, nas rotinas de atendimento, bem como no tipo de interação com outros atores institucionais que lidam com mulheres em situação de violência doméstica, sendo a DEAM melhor articulada com outros serviços do que as SAMs (AZEVEDO et all, 2013:

Outro ponto que merece destaque no texto (p.34) é que a principal referência para a formação de servidores tanto da DEAM quanto das SAMs são treinamentos recebidos na Academia de Polícia. Além disso, o artigo informa que parte significativa dos servidores não recebeu treinamento após ingressar na unidade, o que reflete o:

\footnotetext{
"predomínio de cursos de técnicas policiais sobre a temática específica de gênero e da Lei Maria Penha sugere a prevalência de uma ética de investigação e repressão sobre a ética de acolhimento, ecoando uma tensão há tempos identificada na literatura sobre as Delegacias Especializadas de atendimento à Mulher, entre atividade policial e atividade assistencial". (idem:34).
}

Após toda essa revisão, não há de se surpreender que os atendimentos prestados pela delegacia especializada e pelas delegacias circunscricionais sejam tão diferentes. Ainda assim, ao que parece, a "materialidade da agressão" é fundamental para um atendimento rápido, como citado por Lygia, que foi até a DEAM.

É importante destacar casos como os de Lorena e Carolina que se sentiram totalmente satisfeitas com o atendimento prestado pelas delegacias circunscricionais que recorreram. Chamo atenção para o fato de que, nos discursos dessas mulheres, elas destacaram que foram ouvidas nesses locais e tiveram suas demandas reconhecidas e solucionadas em pouco tempo.

Sobre esse aspecto, Cardoso de Oliveira (2004) lembra que a percepção da desonra ou da indignação experimentada pelos atores acontece quando esses não encontram "instrumentos institucionalizados adequados para viabilizar a definição do evento como uma 
agressão socialmente reprovável (Berger 1983), nem mecanismos que permitam a reestruturação da integridade moral dos concernidos" (p.02).

Cardoso de Oliveira (2004:04) fala que "em qualquer hipótese, a articulação entre reconhecimento e sentimentos no âmbito das obrigações recíprocas indica o potencial destes para a apreensão do conteúdo moral das interações sociais e dos conflitos de uma maneira geral". Nas situações descritas por Lorena e Carolina, ao que parece, houve um esforço e consequente resultado dos profissionais que atenderam essas mulheres não apenas em reconhecer as agressões pelas quais elas passaram, mas, sobretudo, ouvir, reconhecer e tratar com consideração suas demandas. Contudo, os atendimentos oferecidos às mulheres são muito diversos, de forma que o esforço em reconhecer demandas e ouvir as mulheres não ocorre em todas as delegacias.

Ao que parece, essa é uma dificuldade já conhecida. Uma das delegadas que concederam entrevista para a pesquisa intitulada " $\mathrm{O}$ atendimento de crianças, adolescentes e mulheres vítimas de violência pelas instituições de Segurança Pública do Distrito Federal e das Cidades de Porto Alegre e Belo Horizonte" (AZEVEDO et all, 2013) fala sobre "a falta de serviços de apoio social e psicológico para as vítimas, bem como a impossibilidade de equacionar os conflitos através de mecanismos alternativos ao sistema criminal tradicional, configuram um empecilho para que sejam atendidas as necessidades das vítimas". Essa delegada também fala sobre dificuldades entre a demanda das mulheres que chegam até a delegacia e "as possibilidades de administração dos seus conflitos pelo sistema de justiça criminal”. É oportuno citar:

\footnotetext{
A gente teria que rever toda essa concepção. Elas querem falar, elas precisam falar. Elas vêm para a delegacia e elas não querem saber se ele vai ser preso, elas querem falar. (...) O que elas querem é conversar, é dar um susto, é que eles sintam que alguém está apoiando. Então, eu acho que a [Lei] Maria da Penha traz uma demanda de escuta, a vítima quer conversar com o agressor. $\mathrm{O}$ que a gente percebe é que ela quer conversar com ele e eles querem um terceiro que faça uma conciliação. E a Lei Maria da Penha não quer conciliação (idem, p.17).
}

Sobre a necessidade de ouvir as demandas e sobre a importância do atendimento na delegacia, a seguir apresento Clarice e Joana. A experiência de Clarice e Joana ao acionar a LMP é profundamente diferente da experiência relatada por Lia, como veremos a seguir.

\section{6 - Clarice e Joana - "Ele dizia que não tinha nada a perder e que tinha muitos contatos na prisão"}


Clarice me recebeu na casa em que mora com a família. Minha interlocutora é uma mulher idosa, atualmente trabalha como manicure na região em que mora e possui o Ensino Médio completo.

Clarice teve uma única filha, que faleceu há quatro anos. A filha de Clarice deixou duas crianças de relacionamentos diferentes. Clarice manteve contato com a neta mais velha, porém foi impedida de visitar a neta mais nova, que chamarei de Joana. À época da entrevista, Joana tinha dezessete anos. A filha de Clarice estava divorciada havia alguns anos do pai de Joana e Clarice afirma que a relação entre o casal sempre foi conturbada, com muitas brigas e discussões, mas que o genro nunca agrediu a sua filha.

Com a morte da filha de Clarice, a guarda das netas passou para os respectivos pais das adolescentes. Joana foi impedida de manter contato com Clarice, com a irmã mais velha e com qualquer parente da linha materna. Joana foi morar com o pai e com a madrasta em outro bairro e, desde então, passou a ser submetida a maus tratos pelo pai e pela família paterna. Entre os maus tratos estava não ter acesso à alimentação adequada, não poder cultivar amizades, ser transferida de escola para não formar vínculos, sofrer ameaças e agressões físicas. Enquanto isso, Clarice era ameaçada pelo pai de Joana quanto tentava se aproximar da neta.

Clarice conta que, certa vez, Joana ouviu na TV que menores de idade poderiam denunciar seus responsáveis: “Aí, depois de uma vez que ela apanhou, ela disse isso ao pai e ele a trancou em casa e bateu muito mais". Após ter sofrido outra agressão física, Joana conseguiu que uma amiga do colégio a fotografasse e entrasse em contato com a avó materna. A avó materna utilizou as provas produzidas para denunciar o pai de Joana e entrou com um pedido de guarda da menor no Fórum do Núcleo Bandeirante.

Depois disso, Clarice foi agredida verbalmente e ouviu do ex-companheiro de sua filha que, caso ela continuasse tentando obter a guarda de Joana, ele iria "passar o carro por cima" dela e ela teria suas "tripas arrancadas". Clarice também relata que o pai de Joana havia dito "que ele não tinha nada a perder e que tinha muitos contatos". Com as provas, Clarice procurou a delegacia e o conselho tutelar para registrar o BO.

A dimensão da materialidade das provas também está presente no relato de Ana Clara. No caso de Clarice, essa dimensão também é impactante porque revela a dificuldade em conseguir produzir provas. Se Joana não tivesse conseguido, através da sua amiga, produzir fotografias com as marcas das agressões, ela passaria mais tempo vivendo situações de violência. Apesar de existir uma legislação para atender a esse tipo específico de violência, 
claramente ela não é suficiente para atender mulheres que não conseguem produzir provas que comprovem as situações de violência.

A situação relatada por Clarice é totalmente diferente da experiência relatada por Lia. Obviamente porque envolvia uma pessoa que, à época, era menor de idade e a disputa por sua guarda. Os atendimentos que Clarice relatou ter recebido no Conselho Tutelar, na delegacia e no Juizado foram eficientes. Os funcionários de tais locais conseguiram compreender e agir rapidamente para que as suas demandas fossem satisfeitas. A seguir, apresento minha anfitriã Lorena. Assim como Clarice, ela relata como o atendimento que recebeu na delegacia foi fundamental para que suas expectativas fossem atendidas pelo sistema de justiça.

\section{7 - Lorena - "Lá na delegacia ele me disse: - Você vai ver, quando chegar lá em casa, o que eu vou fazer com você essa noite!"}

Lorena escolheu me receber em sua casa, no Riacho Fundo 2, em um dia em que havia conseguido folga no trabalho. Desde 2004, minha anfitriã trabalha em uma empresa que presta serviços de limpeza para o governo local e complementa a sua renda realizando diárias como faxineira. Possui o Ensino Fundamental completo, está casada há 21 anos e tem dois filhos.

Ela conta que conheceu o marido quando ambos moravam em Minas Gerais, em 1992. Ela tinha por volta de 20 anos e o marido era pouco mais velho. Com um ano de relacionamento, casaram-se. Após o casamento, o cunhado da minha anfitriã convidou o irmão e Lorena para se mudarem para a capital federal, pois aqui havia melhores oportunidades de emprego e melhores salários. O casal se mudou e o marido de Lorena passou a exercer a profissão de pedreiro. Logo, nasceram os dois filhos do casal: a mais velha em 1994 e o mais novo em 2001.

Segundo Lorena, o marido ganhava um bom salário como pedreiro, mas após seis anos de casamento ele começou a "beber muito" e a se tornar uma pessoa agressiva. Minha anfitriã conta que, com o tempo, o marido passou a chegar bêbado no trabalho, o que dificultou sua permanência nos empregos que ele conseguia e que, nessa época, "ele ficava mais desempregado do que empregado". Lorena relata que, por muitos anos, ela pagava a maior parte das contas da família, trabalhando como empregada doméstica, diarista e/ou funcionária do setor de limpeza.

Minha anfitriã revela que, desde que começou a trabalhar fora de casa, o marido passou, aos poucos, a beber mais e, consequentemente, a se tornar mais agressivo tanto com 
ela quanto com os filhos do casal. Nessa época, Lorena parou de trabalhar como diarista e organizava o seu dia para que seus filhos estivessem na escola durante o período matutino, enquanto ela trabalhava. Durante a tarde, quando ela voltava do seu trabalho, ficava em casa com os filhos, já que tinha "medo de acontecer alguma coisa".

Segundo Lorena, a família do marido sabia que ele se tornava muito agressivo quando estava alcoolizado e, algumas vezes, ela chegou a ir com os filhos para a casa da sogra, em Taguatinga, pedir auxílio quando sentiu que estavam em perigo. Os vizinhos, por outro lado, não sabiam da situação pela qual a família passava, porque o marido tinha o cuidado de não falar alto quando os ameaçava e, até aquele momento, ele a agredia com ações que não deixavam marcas aparentes, como puxões de cabelo e empurrões. Lorena relata que essas situações eram mais frequentes aos finais de semana, quando o casal e os filhos estavam em casa.

Ela diz que não denunciava o marido porque os filhos e ela tinham "muito medo" do que ele poderia fazer, caso descobrisse que havia sido denunciado, conforme ele sempre ameaçava. Porém, em um domingo no início de 2011, essa situação mudou. O companheiro de Lorena chegou bêbado e muito agressivo em casa e, por volta das $15 \mathrm{~h}$, começou a insultar a interlocutora e os filhos do casal com palavras de baixo calão e ameaças. Com o passar das horas, ele ficou mais agressivo e disse que iria matá-la e em seguida matar as crianças. O filho do casal conseguiu sair de casa correndo e ligou para a polícia, que chegou rapidamente:

\footnotetext{
Nesse dia o meu filho me disse: - Mamãe, eu não aguento mais! E foi e chamou a polícia. Nessa hora, eles chegaram e vieram me perguntar se era realmente aquilo e eu falei que era. Porque eu acho assim, que se eu não tivesse falado... Porque muitas vezes as pessoas negam, né. Eu tenho uma irmã que passa por isso, mas ela nega quando os vizinhos chamam. Ela mora em outro Estado. Quando eles (a polícia) chegam lá e ela fala que não é ali, que ele não faz nada... Aí a polícia não pode fazer nada. Ela fala para gente o que acontece, aí quando alguém chama a polícia, na hora ela não tem coragem de fazer nada. Ela tem medo.
}

Minha anfitriã lembra que os policiais militares chegaram pouco tempo após o filho mais velho do casal ter ligado para a polícia e que, quando os policiais chegaram, o marido foi logo dizendo que "não havia problema nenhum". Minha interlocutora conta que "desabafou e contou tudo o que estava acontecendo", confirmando a versão contada pelos filhos do casal aos policiais, que relataram as agressões que a família vinha sofrendo quando o pai estava alcoolizado. Lorena conta que, enquanto ela relatava o que a família vinha passando, o marido, ainda alcoolizado, chegou a ameaçar os policiais. "Aí os policiais deram uma chamada nele, falaram: 'você está falando com gente da Lei, você não pode falar assim'”. Em seguida, todos foram levados para a delegacia. 
Minha anfitriã conta que, ao chegar na delegacia, ela narrou todas as situações de violência que ela e os filhos estavam vivendo. Eu perguntei se o marido chegou a agredir ela ou os filhos do casal fisicamente ou ameaçá-los com algum objeto e Lorena respondeu: "Não, não. Não chegou a esse ponto, eu acho que porque eu fui atrás a tempo. Eu acho que poderia chegar. Coisas que antes ele não fazia, que era me empurrar, ele já estava me empurrando. Já era um começo, né!?”.

Lorena relata que, quando a família estava na delegacia, os filhos confirmaram os acontecimentos descritos pela mãe em seus depoimentos e também relataram aos agentes as ameaças e agressões que o pai fazia contra eles. Lorena conta que os filhos disseram que, além das agressões e ameaças que eles sofriam na presença da mãe, durante muito tempo o pai os ameaçou também nos momentos em que minha interlocutora não estava presente. $\mathrm{Na}$ delegacia, Lorena me disse que perguntaram se ela queria prosseguir: "Eles perguntaram se eu queria continuar e eu disse: Quero. Porque aquela vida que eu levava eu não aguentava mais. Eu estava no meu limite". Durante a entrevista, Lorena chama atenção para outro fato importante que ocorreu na delegacia:

Aí depois, lá dentro da delegacia, ele me ameaçou ainda, e nisso eles viram né. Aí ele foi preso. Ele disse - Você vai ver, quando chegar lá em casa, o que eu vou fazer com você essa noite! Aí o delegado, eu acho que foi, ouviu e disse: - Você está ameaçando ela? Então daqui você não vai sair não! Aí ele ficou lá e a gente veio embora. Aí de lá ele ficou preso.

Após essa ameaça, Lorena e os filhos voltaram para casa e o marido dela ficou na delegacia. Lorena me contou que ele chegou a ser transferido para o Complexo Penitenciário da Papuda. Segundo minha anfitriã, ele passou alguns dias preso na penitenciária e saiu porque a família dele providenciou um advogado e resolveu os trâmites burocráticos. Quando saiu da penitenciária, o companheiro de Lorena pediu para voltar para casa e ela o aceitou. Ele prometeu que iria mudar e Lorena resolveu dar uma segunda chance ao companheiro.

\section{8 - Conceição - "Eu morava num lote que tinha outra casa. Muitas vezes eu gritava e a vizinha vinha socorrer".}

Conceição foi uma das minhas anfitriãs que escolheu me receber no seu ambiente de trabalho. Há cerca de quatro anos ela trabalha como secretária em uma instituição localizada no Plano Piloto. Para ela era mais fácil nos encontrarmos no horário de almoço do que após às 18h, quando ela volta para sua residência, localizada em uma Região Administrativa do DF. Minha anfitriã é paraibana e conta que conheceu o ex-marido quando os dois estavam 
terminando de cursar o Ensino Médio, em Maceió - AL. Naquela época, Conceição estava divorciada e era mãe de uma pessoa com deficiência ${ }^{86}$, que tinha um pouco mais de um ano de idade.

Ela e o marido mantiveram o relacionamento por onze anos e tiveram duas filhas. Segundo Conceição, a partir do segundo ano morando juntos começaram as agressões verbais. Conceição lembra que, na primeira vez em que ele a agrediu fisicamente e a ameaçou com um revolver, o casal ainda morava em Alagoas, no período em que ela estava de resguardo após o nascimento da última filha do casal.

O ex-companheiro chegou em casa bêbado e os dois iniciaram uma discussão que terminou quando ele mostrou para ela que estava armado. Após ver a arma do então companheiro, Conceição gritou por socorro e o empurrou na cama. Como ele estava bastante alcoolizado, Conceição disse que ele foi pego de surpresa e não teve nenhuma reação rápida, de modo que ela conseguiu desarmá-lo e pouco tempo depois os vizinhos chegaram. Ela diz que não se lembra com detalhes porque essa experiência a traumatizou. Após esse episódio, ela foi com as crianças para a casa dos pais e o cunhado levou a arma do então marido. Após essa experiência, a família de Conceição passou a incentivá-la a pedir o divórcio, porém, um tempo depois desse acontecimento, o casal decidiu se reconciliar.

Após esse episódio, o casal se separou por um tempo, mas reataram após o excompanheiro prometer mudanças. Alguns anos depois, a família se mudou para Brasília em busca de melhores empregos. Conceição relata que já tinha parentes morando na cidade e que outro fator importante foi que aqui ela conseguiria ter acesso ao tratamento que seu filho mais velho precisava, oferecido por um hospital localizado no Distrito Federal. Com a mudança e o custo mais elevado para cobrir as despesas, Conceição começou a trabalhar fora de casa e conseguiu mais "independência financeira".

Ela conta que, após a mudança, o ex-companheiro passou a ser mais ciumento e controlador, principalmente em relação aos horários em que ela chegava do trabalho. Durante a semana, discutiam se ela atrasasse para chegar em casa, se perdesse o ônibus, se ficasse muito tempo em congestionamentos e também porque o ex-marido nunca tratou com consideração o filho do primeiro casamento de Conceição. Aos finais de semana, as discussões se transformavam em brigas após o ex-companheiro ingerir bebidas alcoólicas, o

\footnotetext{
${ }^{86}$ A portaria $^{\circ} 2.344$, de 3 de novembro de 2010 definiu "pessoa com deficiência" como o termo adequado. Para mais informações, consultar: http://pesquisa.in.gov.br/imprensa/jsp/visualiza/ index.jsp?jornal $=1 \&$ pagina $=4 \&$ data $=05 / 11 / 2010$
} 
que acontecia "quase todos os finais de semana". Ela revela que pessoas de seu antigo emprego chegaram a perceber as marcas das agressões no corpo dela.

Minha anfitriã relata que os amigos e a família dela, que moram em Alagoas, sempre a incentivaram a se separar e que, aos poucos, ela "começou a criar coragem". Ela me conta: "Minha mãe ficava, como é que se diz, rezando o tempo todo, porque a qualquer hora ela podia receber uma ligação, dizendo que tinha acontecido uma coisa pior”.

Uma circunstância interessante é que foi a vizinha, que reside no mesmo lote que a família de Conceição (residem no mesmo lote, mas moram em casas diferentes), quem denunciou o marido da minha interlocutora. Conceição conta que a vizinha de lote já havia ouvido e presenciado várias discussões e que, algumas vezes, ao ouvir pedidos de socorro e presenciar agressões contra minha anfitriã, a vizinha apartou a briga entre Conceição e o exmarido. Conceição diz que essas situações era recorrente: "Muitas vezes eu gritava e a vizinha vinha socorrer. Aí ela vinha e falava: - Você tá louco? Não faz isso!"’.

Após uma briga em que o marido estava muito bêbado e agressivo, a interlocutora começou a gritar por socorro, a vizinha de lote ouviu e ligou para a polícia que, pouco tempo depois, chegou ao local. Conceição e o então companheiro seguiram com os policiais para a delegacia. Ela lembra que o ex-marido não ficou detido e que não houve nenhuma medida que impossibilitasse o contato entre os dois. No dia seguinte, ele retornou para a casa que a família morava, pois, à época, não havia nenhuma medida protetiva de afastamento em vigor:

\begin{abstract}
Aí ele saiu de casa, mas voltou no outro dia. Ficou um clima muito pesado dentro de casa. Eu fiquei com medo, toda hora. Eu chegava em casa e já me trancava no quarto, às vezes a gente ficava no mesmo quarto, mas aí eu colocava um colchão, sabe? Essas coisas. Foi difícil (...). Aí era aquela coisa. Todas as agressões eram risco de vida. E a qualquer momento ele ficava tão transtornado, que tanto que eu escondia, eu vivia com faca escondida. Quando ele estava perto de chegar em casa eu já escondia as facas de cozinha, mesmo ele estando trabalhando em um dia comum. Eu já deixava escondida para ficar mais difícil o acesso, para eu me proteger, essas coisas.
\end{abstract}

Tempos depois, houve outra grande briga e a vizinha, novamente, chamou a polícia que foi até a casa de Conceição. Minha anfitriã acha que "alguma coisa teria acontecido" se a vizinha não tivesse ligado para a polícia. Conceição conta: "Se não fosse ela eu acho que, nesse dia, ele tinha feito alguma coisa comigo. Ela, que é forte e alta, ajudou a segurar ele uns dez minutos, até ele falar que não ia fazer mais nada não". Conceição diz que "a vizinha ajudou demais" e relata que ela e a vizinha conversavam sobre as agressões que sofria. Ela 
lembra que, após essa briga, ela e a vizinha conversaram outra vez: "Ela pegou e me disse assim: -Você vai tomar uma atitude ou esse homem vai te matar".

No caso de Conceição, assim como no caso de Ana Clara, Lygia e de outras mulheres, o apoio da rede afetiva foi fundamental para que elas registrassem a denúncia contra os respectivos parceiros violentos. Durante o campo, percebi que a violência doméstica nunca é vivida de forma isolada, somente pela mulher que sofreu as agressões.

Nos nossos encontros, percebi que o apoio de familiares, atuais companheiros, amigas, colegas de trabalho, foi fundamental para que essas mulheres decidissem procurar o apoio do Estado. Inclusive, na fala de algumas interlocutoras, ficou claro que, sem esse apoio, elas não teriam efetivado a denúncia. Algumas das minhas anfitriãs disseram, por exemplo, que decidiram denunciar a situação pela qual estavam passando após conversar sobre o que vivenciavam com pessoas que compunham suas redes afetivas.

Essa rede se apresenta de forma diferente ao longo dos casos. A interferência da família na relação, por exemplo, varia bastante de caso para caso, já que existem situações em que a mulher prefere, por exemplo, ocultar a violência que vem sofrendo da família e compartilhá-la com outras pessoas. Em outros casos são colegas de trabalho ou amigas que incentivam e apoiam a denúncia.

Compreendo que as redes afetivas podem contribuir para entendermos os pontos de vista das mulheres que passam por situações de violência. Destaco também que o fato de essas mulheres contarem com uma rede de apoio que se mostrou importante para que a denúncia fosse registrada, essas redes não desmerecem o fato das mulheres terem procurado a delegacia. Ainda que essa tenha sido uma decisão que contou com o auxílio de outras pessoas, continua presente a agência da mulher em sua decisão de buscar atendimento através da Lei 11.340/2006. Porém, considero relevante refletir sobre a importância das redes afetivas para as mulheres que vivem situações de violência e de pensarmos sobre o caráter coletivo dos sentimentos (MAUSS, 1979:153) que estão presentes nessas redes.

Neste sentido, a interpretação de Soares (2005:37-38) pode nos auxiliar a compreender esse contexto. A autora utiliza o chamado "o modelo ecológico", que compreende que a noção de violência deve ser compreendida coletivamente:

Considerando-se a interação desses fatores, desenvolveu-se um modelo para compreender a violência: o modelo ecológico. Observe que, segundo esse modelo, a violência estaria relacionada à interação de quatro planos: o individual, o relacional, o comunitário e o social. Cada um desses planos engloba o anterior, tanto para reforçar, quanto para prevenir os elementos de risco. Por exemplo: fatores históricos, biológicos, pessoais, como a impulsividade, abusos sofridos na infância ou o uso 
abusivo de substâncias químicas (plano individual), podem ou não favorecer a violência, dependendo da qualidade das relações familiares e de amizade: o tipo de suporte dado pela família e pela rede de relações próximas faz toda a diferença (plano relacional). Da mesma forma, a natureza dos vínculos que ligam uma pessoa ao seu entorno - vizinhos, ambiente de trabalho, amigos, grupo de igreja ou associações (plano comunitário) pode abrir ou fechar as portas para a violência. Pode ser que a violência não encontre meios de se manifestar, se a pessoa faz parte de uma rede sólida e estável e solidária.

$\mathrm{O}$ apoio das redes parece fundamental para que a denúncia seja efetuada. Nesta perspectiva, pude perceber que o ato de conversar com outras pessoas sobre a violência vivida pode ser um incentivo a mais para que a mulher decida acessar o sistema de justiça criminal através da LMP.

Voltando novamente nossa atenção para Conceição, minha anfitriã relata que, quando a polícia chegou, ela, a vizinha e o ex-marido foram levados para a delegacia. A vizinha foi testemunha da ocorrência registrada por Conceição. Minha anfitriã conta que esse foi um momento importante porque, nessa segunda vez que ela foi à delegacia, informaram que o excompanheiro teria que sair de casa: "Eles falaram assim 'Olha, o senhor vai ter que sair de casa mesmo"".

Ela conta que, após essa última ida à delegacia, eles se separaram e o ex-companheiro saiu de casa e foi morar com um amigo, perto da casa em que Conceição e os filhos moravam. Minha anfitriã lembra que, nesse período, mesmo estando separados, quando o excompanheiro sabia que ela havia saído de casa "vinha cobrar satisfação". Por isso, Conceição diz que, nos primeiros dois anos após a separação, ela não se envolvia em outros relacionamentos amorosos porque "tinha medo de me envolver em outros relacionamentos e que a pessoa frequentasse a minha casa”.

\section{9 - Nadine - "O que mais me motivou a ir a delegacia foi a minha mãe, enchendo o saco. Na hora eu nem pensei nisso".}

Nadine é brasiliense, tem 25 anos, é mãe de duas crianças de diferentes relacionamentos e atualmente trabalha com promoção e vendas de serviços por telefone, em uma empresa localizada no Plano Piloto. Ela escolheu me receber no apartamento que atualmente divide com a irmã. Nadine conta que trancara a matrícula na faculdade que cursava alguns meses antes do nosso encontro, por motivos financeiros e familiares, mas que pretendia retomá-la.

Minha anfitriã conta que a primeira vez que acionou a Lei Maria da Penha foi contra o pai da primeira filha, no início do ano de 2013. O relacionamento começou quando ambos 
estavam cursando o final do Ensino Médio e durou seis anos. O casal nunca chegou a morar junto e, ao final da gravidez da primeira filha de Nadine, que atualmente está com três anos de idade, decidiram se separar. Nadine conta que sempre trocavam acusações e ofensas, inclusive em locais públicos. Porém, até esse momento, não havia agressões físicas ou ameaças.

Segundo a minha interlocutora, após a separação, as brigas continuaram. Ela conta que em um final de semana, quando o ex-companheiro foi buscar a filha para a visita regulamentada, ficou extremamente irritado pelo fato de a criança ainda não estar pronta. Quando ela foi entregar a criança, o ex-companheiro partiu em sua direção e tentou atingir o pescoço de Nadine, que reagiu. O ex-namorado então tentou segurá-la e a machucou com arranhões em um dos braços. Sobre esse dia, Nadine diz: "Só que isso já foi a última gota de tudo, porque a gente brigava muito".

Ela conta que quando foi agredida pelo ex-parceiro, ela ainda não sabia, mas já estava grávida do segundo filho. Na época que essa agressão aconteceu, a mãe de Nadine estava no apartamento em que ela mora e, quando minha interlocutora chegou em casa, viu que a filha estava com o braço machucado. Naquele momento, Nadine não pensou em ir à delegacia, mas a mãe conversou com ela e a incentivou. No mesmo dia, pouco tempo após a agressão, Nadine foi com a mãe até à delegacia para prestar o boletim de ocorrência contra o excompanheiro.

Consegui os dados de Nadine ao pesquisar os processos que passaram pelo Fórum Hugo Auler e que já haviam sido encerrados. Ela me contou que a agressão ocorreu após o casal ter se separado, no momento em que o pai da filha mais velha de Nadine foi buscar a criança para a visita de final de semana. Nadine conta que o casal teve uma discussão porque Nadine se atrasou e demorou mais que o previsto para arrumar a filha. Quando minha anfitriã desceu com a criança, os dois começaram a discutir e entre várias ofensas ditas, o excompanheiro de Nadine segurou seu braço à força e a arranhou.

Após a discussão, que durou alguns minutos, Nadine voltou para sua casa, bastante nervosa. Sua mãe viu que ela estava com o braço machucado e perguntou o que havia acontecido. Elas conversarem e, embora naquele momento Nadine não tenha pensado imediatamente em ir à delegacia, a mãe a incentivou a fazer o boletim de ocorrência contra o ex-companheiro. Ela conta que quando chegou em casa, a mãe a viu e "ficou revoltada com a agressão": 
gritava e xingava... Tudo dele era xingar... E hoje, depois disso ele é outra pessoa. Não sei se é por medo de eu fazer alguma coisa...

Nadine também contou que estava envolvida em um novo processo relacionado à violência doméstica. Desta vez, com outro companheiro, pai da sua segunda filha. Ele a agrediu em agosto de 2014, dois meses antes da entrevista e, portanto, esse processo ainda estava em curso. A entrevista com Nadine aconteceu em uma sexta-feira e ela me disse que havia faltado à audiência referente a esse novo processo, que havia acontecido naquela mesma semana, quatro dias antes da entrevista. Ela disse que não compareceu porque não tinha com quem deixar a filha mais nova, de um ano de idade, fruto da relação com o último companheiro, requerido do processo mais recente.

Nadine conta que a segunda agressão aconteceu quando ela, suas filhas e o então namorado estavam voltando de um churrasco. As crianças choravam no carro porque queriam continuar no evento. Nadine relata que o casal havia ingerido bebida alcoólica e que acredita que, devido a este fator, a discussão saiu do controle.

Bem próximo a casa em que Nadine morava, o casal começou a discutir dentro do carro e o companheiro a agrediu com um soco no nariz enquanto dirigia. Após a agressão, Nadine imediatamente saiu do carro: "Isso aqui (aponta para a calçada) ficou tudo cheio de sangue. A intenção dele foi essa. A desculpa pode ser porque a gente tinha bebido, mas que foi porque ele quis. Ele pensou para fazer. Foi muito assim... espontâneo!”.

A filha mais velha de Nadine correu em direção à mãe e começou a chorar e a gritar ao ver o sangue. O ex-companheiro e pai da primeira filha de Nadine - que mora próximo a ela , reconheceu a voz da criança e foi em direção ao local saber o que havia acontecido. O então namorado de Nadine foi embora e ela ficou acompanhada do ex-companheiro.

Minha anfitriã relata que na hora ficou tão atordoada que só pensava em ir para casa se limpar e acalmar as crianças. Seu ex-companheiro foi quem insistiu para que ela fosse à delegacia: "Ele que insistiu. Porque do jeito que eu fiz com ele por muito menos... Aí ele ficou doido... Aí ele ficou enchendo o saco". No mesmo dia em que aconteceu a agressão, Nadine foi à delegacia circunscricional que atende a região em que ela reside, desta vez acompanhada do ex-companheiro.

Analisando a segunda denúncia especificamente, chama atenção o fato de o exparceiro de Nadine ter insistido para que ela denunciasse o namorado que a agrediu. Há aqui uma relação de honra, quando o ex-companheiro de Nadine insiste para que ela denuncie o atual parceiro, tendo em vista que ela o denunciou "por muito menos". 
Segundo Berger (1983), há uma negação contemporânea da realidade da honra e das ofensas contra a honra. Para Berger, a obsolescência do conceito de honra aparece nitidamente na dificuldade de muitos contemporâneos em entenderem o insulto, que em essência é um ataque à honra. Em contextos como o americano, Berger revela que motivações que apelem para a honra não possuem legitimidade. Para esse autor, o conceito de honra implica em perceber que a identidade -o self - está essencialmente ligado a papéis institucionais. Por outro lado, o conceito moderno de dignidade implica que a identidade é essencialmente independente de papéis institucionais.

O ex-companheiro de Nadine também a incentivou a ir à delegacia - e foi, inclusive, testemunha - porque ele ficaria desonrado, caso Nadine decidisse não denunciar o homem que a agrediu, já que o havia denunciado por uma agressão que ambos consideravam como "menor", porque fisicamente havia machucado menos Nadine.

As situações relatadas por Nadine trazem, novamente, à tona a importância de compreender as redes afetivas para as mulheres em situação de violência. Esse aspecto chama atenção para a importância de compreender o contexto em que aquela mulher está vivendo e a dimensão relacional que envolve a denúncia e registro do $\mathrm{BO}$ e todo o andamento do caso no sistema de justiça.

Nadine chama atenção para o fato de que, embora tenha ido à mesma delegacia nas duas situações em que ela foi agredida, o atendimento foi diferente. Ela conta que, na primeira vez, o agente que a atendeu registrou a ocorrência e pediu para que ela aguardasse na delegacia. Ela foi encaminhada para o IML "porque o cara da delegacia que mandou eu ir", mas não teve que retornar à delegacia. Já no segundo caso, ela relata que foi à delegacia e que o pai de sua primeira filha testemunhou contra o seu ex-namorado. Ela conta que da delegacia ela foi para o IML e lá ela foi encaminhada para um hospital, porque o rosto dela continuava sangrando. Nadine lembra que, nessa segunda ocorrência, ela teve que comparecer à delegacia um mês após ter registrado a ocorrência ${ }^{87}$ e só depois encaminharam o inquérito para o Fórum.

\subsection{0 - Hilda - "Porque não era mais só comigo, era com a criança também! Ele já estava achando que podia agredir a criança também!"}

\footnotetext{
${ }^{87}$ Quando questionei os motivos que a fizeram ir novamente à delegacia, Nadine disse não ter entendido muito bem porque dessa vez havia demorado mais. Ela conta que telefonaram para ela, ela foi à delegacia, respondeu a algumas perguntas sobre o ocorrido e foi informada que o inquérito seria encaminhado para o Fórum Hugo Auller.
} 
Hilda tem cerca de 30 anos e escolheu me receber em sua casa. Na época da entrevista, Hilda se dedicava aos cuidados com o filho, a atividades domésticas e estava cursando o Ensino Médio. Conta que decidiu voltar a estudar após ter se separado do marido e que pensa em cursar faculdade de psicologia, mas, ao mesmo tempo, disse que "não quer mais nada que prenda". Pensativa, me diz que no futuro, quando o filho for maior de idade, gostaria de ter economizado dinheiro suficiente para "ir embora e viajar para outros lugares do mundo".

Hilda migrou do interior de um pequeno município do Ceará para Brasília quando tinha 15 anos de idade. Conta que nunca gostou da vida no interior, que se sentia presa naquele ambiente. Uma família próxima aos pais dela havia se mudado há alguns anos para a capital federal e precisava de alguém para cuidar das crianças pequenas. Voltaram para a cidade para visitar parentes, Hilda ficou sabendo da história e perguntou aos pais se ela poderia trabalhar e morar em Brasília. Pouco tempo depois, ela se mudou para a capital do país.

Minha anfitriã conta que conheceu o ex-marido na igreja que frequentavam. Ela relata que logo engataram um namoro tranquilo, que durou cinco anos e, após esse período, ficaram casados por mais dez. Dessa união nasceu o único filho do casal, que à época da entrevista tinha oito anos de idade. Hilda relata que, com o passar do tempo, o marido tornou-se agressivo: “-Começou com agressões verbais, depois empurrões, puxões de cabelo e depois foi ficando mais intenso. Foi acontecendo aos poucos". Hilda diz que as agressões - que aconteciam, sobretudo, aos finais de semana - foram piorando ao longo dos anos e que "virou rotina". No entanto, ela não pensava em procurar a justiça porque o casal sempre fazia as pazes e o companheiro "pedia desculpas". Além disso, Hilda disse que "não queria que o casamento acabasse".

Durante o período em que esteve casada, Hilda viveu situações de violência física que aconteceram em diferentes momentos e que nunca compartilhou o que passava com a família ou com outras pessoas. Segundo minha anfitriã, "foi um choque para todo mundo, porque ninguém acreditava que isso acontecia. A exceção foi a mãe de um amigo, senhora de idade avançada, que acabou tornando-se sua amiga e confidente. Hilda conta que essa senhora a aconselhava a procurar outras alternativas e soluções para o "problema" que ela vivia e elas compartilhavam esse pensamento. Para Hilda e para a sua amiga, procurar a justiça não iria adiantar e, se fizesse essa opção, minha anfitriã iria "acabar com o casamento".

Sobre esse aspecto, como Pasinato e Santos, compreendo a necessidade de investigar o contexto em que ocorre a violência. É necessário entender as relações dessas mulheres a partir 
do ponto de vista delas e a maneira como elas analisam suas trajetórias. A seguir, cito reflexão de Pasinato e Santos (2005:153) sobre esse tema:

\begin{abstract}
É necessário relativizar o modelo de dominação masculina e vitimização feminina para que se investigue o contexto no qual ocorre a violência. As pesquisas sobre o tema vêm demonstrando que a mulher não é mera vítima, no sentido de que, ao denunciar a violência conjugal, ela tanto resiste quanto perpetua os papéis sociais que muitas vezes a colocam em posição de vítima. O discurso vitimista não só limita a análise da dinâmica desse tipo de violência como também não oferece uma alternativa para a mulher.
\end{abstract}

Hilda enfatiza que, embora houvesse agressões, o casal se reconciliava. Em 2005, Hilda engravidou. Minha anfitriã diz que quando soube que estava grávida foi conversar com o companheiro e pediu para que o então marido "tivesse mais cuidado". Para Hilda, a partir daquele momento, eles não deveriam mais utilizar palavras de baixo calão ou se agredirem.

No entanto, quando ainda estava grávida, o casal teve outra grande discussão e ela recebeu vários socos e pontapés. Até a separação, Hilda relata que sofreu diversas agressões físicas, verbais e ameaças, inclusive na presença do filho do casal. . Em 2012, Hilda pediu o divórcio e o ex-marido saiu de casa. Hilda conta que o ex-marido passou a, constantemente, abusar de bebidas alcoólicas após a separação

A agressão que motivou a denúncia de Hilda aconteceu pouco mais de um ano após a separação. Ela conta que, após passar o final de semana com o pai, o filho chegou em casa chorando, alegando ter recebido um tapa no rosto. Imediatamente, ela ligou para o excompanheiro para pedir satisfações sobre o ocorrido. Ele desligou a ligação e retornou para a casa de Hilda. Ela conta que pensou que eles iam conversar sobre o ocorrido, mas, assim que ela abriu o portão, o ex-marido disse que ele poderia bater em qualquer local do corpo da criança que ele quisesse e começou a agredi-la com pontapés, empurrões, puxões de cabelo, socos, tapas. Após o ex-marido sair da sua residência, Hilda pegou a criança e foi até à delegacia.

Nesse caso, diferentes moralidades se mostram em jogo. Hilda nunca procurou a polícia após ter sofrido uma agressão do marido enquanto eram casados e sua rede afetiva, representada pela senhora com a qual ela se aconselhava, pensava da mesma maneira. Elas acreditavam que era Hilda que precisava sair daquela situação por ela mesma e não utilizar o sistema de justiça para interromper a situação de violência, porque, na perspectiva de Hilda, “a lei sozinha não ajuda".

Nessa frase, Hilda estava se referindo ao fato de que, na época em que estava casada, ela dependia financeiramente do marido. Nessa época, Hilda era dona de casa e não 
desempenhava nenhuma atividade remunerada. Ao afirmar que "a lei sozinha não ajuda", Hilda queria dizer que, se ela houvesse denunciado o ex-companheiro quando dependia financeiramente dele, não teria mecanismos para conseguir se sustentar e manter a casa. Uma fala da minha anfitriã é bem representativa sobre esse aspecto: “Antes de ir procurar a polícia porque o marido bateu, saia de casa, vá embora, procura outro jeito, procura um emprego, estudar... Procure dar um jeito".

Ela conta que a senhora que era sua confidente partilha a mesma opinião sobre esse assunto. Antes de prosseguir com a análise, é importante destacar que em nenhum momento Hilda defendeu que mulheres devam apanhar ou aceitar uma vida com violência. Mas Hilda só decidiu ir à delegacia quando o ex-companheiro agrediu o filho do casal. Quando o excompanheiro agrediu o filho do casal que, após a separação vivia sob a guarda dela, estava em jogo não mais o seu comportamento como (ex) esposa, mas sim como mãe.

E isso significa que também estava em jogo o controle sobre a integridade física da criança. Segundo Hilda, se ela não tomasse uma providência imediatamente após a situação ter acontecido pela primeira vez, esse tipo de situação poderia se repetir várias vezes e ela não teria "moral" para argumentar, pois já havia permitido - e se resignado - essa situação em um determinado contexto:

\footnotetext{
Ele - o ex-marido - tinha perdido completamente o controle e se eu não fizesse aquilo naquele momento... porque não era mais só comigo, era com a criança também! Ele já estava achando que podia agredir a criança também! Aí eu não ia deixar ele bater no menino porque ele é pai e achava que podia agredir o menino em qualquer lugar... E aí eu ia ficar aquela que não podia reclamar. E eu nunca ia aceitar que ele fizesse aquilo com a criança. Nunca ia aceitar! Aí eu não ia poder reclamar se o menino chegasse aqui apanhado, machucado, porque aí ele ia bater no portão e chegar aqui com quatro pedras diante de mim.
}

Sobre a agressão, Hilda conta que o filho chegou em casa no sábado à noite, após passar o dia com o pai e disse que havia apanhado no rosto. Minha anfitriã conta que essa situação a deixou muito nervosa e ela telefonou para o ex-companheiro com o intuito de cobrar explicações sobre a agressão. Hilda estava inconformada porque, para ela, "não se bate no rosto de uma criança". Na ligação, o ex-marido respondeu que "o filho era dele e ele batia aonde ele quisesse". Hilda retrucou que não era assim, que eles precisariam conversar porque "ele não pode bater na criança aonde ele quer".

O ex-companheiro, que estava dirigindo no momento da ligação, disse que estava voltando para que eles conversassem. Cito Hilda: 
Ele chegou alterado, acho que tinha bebido, não sei o que foi. É certo que não era ele, era outra pessoa. Aí ele já veio desse jeito, sem nenhum temor. Com pontapés, com empurrões, com tapas, com tudo mesmo. Foi uma briga bem feia, que a gente ficou lá fora, depois veio para dentro. Ele me xingou, me deu chutes na barriga, tapa e eu cheguei até a desmaiar um pouco, e na cabeça com o cabo de rodo e tudo o mais (...). Acho que isso tudo durou uma meia hora. E nesse tempo todo, a criança viu. Só não presenciou mais porque ele foi para debaixo da cama. Ele ficou caladinho lá debaixo da cama. De certo que ele já foi pegar o menino debaixo da cama, puxou o menino para ele se acalmar. E disse para o menino se acalmar, falando que a culpada era eu, que eu que tinha procurado aquilo.

Após o ex-marido ter saído da casa, Hilda se recuperou e em seguida "peguei o menino, meus documentos e fui dar queixa na delegacia". Hilda optou em ir diretamente à delegacia da mulher e não à delegacia localizada no Núcleo Bandeirante, que também atende a região em que ela mora. Ela conta que, rapidamente, foi atendida e disse que queria "fazer uma queixa contra o ex-marido". Minha anfitriã falou que ele tinha a agredido e contou das agressões que viveu durante a relação.

Hilda fala que a ouviram com atenção e que, na delegacia, explicaram sobre a LMP e que o inquérito seguiria para o Fórum. Ela conta que foi ao IML e fez todos os exames. Minha anfitriã diz que, na segunda-feira, após ter prestado a denúncia, uma moça foi à sua casa com uma notificação que proibia o ex-companheiro de se aproximar.

\subsection{1 — Rachel — "Eu tinha medo dele vir atrás, eu tinha medo dele tomar a criança".}

À época da entrevista, Rachel me recebeu em sua casa, em uma cidade de Goiás localizada na região do entorno do DF. Rachel é brasiliense, possui o Ensino Médio completo e tem duas filhas: uma do primeiro relacionamento, que tem 8 anos de idade e a outra criança tem pouco mais de 1 ano de idade e é fruto do atual casamento da minha anfitriã. Rachel explica que ela e o atual marido optaram por ela sair do emprego para cuidar da filha até a menina ficar um pouco mais velha.

O primeiro casamento de Rachel durou oito anos e eles tiveram uma filha em comum que, à época da separação, tinha 5 anos de idade. Ela conta que eles se conheceram em uma festa, quando ela tinha 18 anos. Pouco tempo depois começaram a namorar e, com dois anos de relacionamento, ela engravidou da única filha do casal. Após oito anos de relacionamento, Rachel decidiu terminar a relação com o ex-marido porque conta que discutiam constantemente e a relação estava muito desgastada.

No entanto, o ex-companheiro não aceitou o término da relação e, após se separarem, Rachel começou a ser perseguida. Essa situação se agravou devido ao fato de o ex-marido de 
Rachel morar próximo à casa da família dela, local para onde ela havia se mudado após a separação, na Candangolândia. Nesse período, Rachel trabalhava como auxiliar na área de comunicação de uma empresa localizada no Plano Piloto e utilizava transporte público para fazer o trajeto trabalho-casa. O ponto de ônibus era próximo à casa do ex-marido, que aproveitava essa coincidência para controlar os horários em que ela saía e chegava em casa.

Após a separação, o ex-marido passou a segui-la e frequentemente ligava para Rachel para cobrar satisfações sobre porque ela estava atrasada, a que horas ela chegaria em casa, ou se ela estava se relacionando com alguma outra pessoa. Ela conta que, nesse período, ele telefonava e enviava mensagens de texto para ameaçá-la e ofendê-la: “-Às vezes ele mandava umas mensagens assim '-Tá namorando, piranha?'. Mas depois foi diminuindo. Aí eu falava que ia na delegacia e ele parava. Eu falava 'polícia' e ele parava”.

Minha interlocutora relata que ela evitava se relacionar com homens que moravam no seu bairro "porque eu tinha medo dele vir atrás, eu tinha medo dele tomar a criança". Ela conta que, um dia, ele chegou a agredi-la com um tapa no rosto e com puxões de cabelo em uma discussão pós-separação que começou após ele pedir explicações sobre os horários em que ela chegava em casa.

Rachel conta que amigas dela desistiram da amizade por sentirem medo dele e acharem que também estavam em risco. Ela conta que, um dia, ele foi ao ponto de ônibus próximo ao trabalho dela e a ameaçou para que entrasse no carro dele, "senão eu ia me arrepender". Ela, rapidamente, entrou no primeiro ônibus que estava parado no ponto e percebeu que o ex-marido estava seguindo o ônibus. Nesse dia, minha interlocutora conseguiu despistá-lo pegando conduções com destinos diferentes até perceber que ele havia desistido e, então, voltar para casa.

Apesar dessas situações, minha interlocutora decidiu não denunciá-lo. No período após a separação, Rachel evitava sair para locais em que pudesse encontrar com o ex-marido. Uma prima dela, que morava em outra região do DF, começou a chamá-la para sair nos finais de semana em que o ex-marido ficava com a filha do casal. Foi nessa época, aproximadamente um ano após a separação, que Rachel conheceu o atual companheiro.

Movido por ciúmes do recém-casal, o ex-companheiro recomeçou a perseguir Rachel. Em uma ocasião, quando o atual companheiro deixava Rachel em casa, o ex-marido apareceu e começou a quebrar o carro em que estava o casal com chutes e pontapés. Os dois homens começaram a brigar na rua e, ao tentar separá-los, Rachel recebeu um murro do ex-marido no seu olho esquerdo. Após ter quebrado o carro em que estava o casal e ter percebido que atingiu Rachel, o ex-marido fugiu do local. Rachel e o namorado foram à delegacia. 


\subsection{2 — Marina — "Ele estava em sã consciência. Eu tenho certeza absoluta"}

Marina me recebeu em seu apartamento, localizado na Candangolândia, em outubro de 2014. Marina tem pouco mais que 40 anos e possui formação superior em Relações Internacionais, mas deixara o emprego havia pouco tempo. Ela estava noiva de uma pessoa que morava em outro estado e, como estavam com o casamento marcado, em breve ela se mudaria do Distrito Federal.

Marina relata que conheceu o ex-namorado em 2008. À época, ela trabalhava em um cargo comissionado em uma das Administrações Regionais do Distrito Federal e o namorado também trabalhava naquele órgão. Entre idas e vindas, o relacionamento durou dois anos.

Durante a relação, o ex-namorado de Marina tornou-se usuário de crack. Minha interlocutora conta que o casal se separou após ela perceber que não reconhecia mais o exnamorado, pois ele "havia mudado muito". Pouco tempo após a separação, Marina conta que o ex-namorado foi internado compulsoriamente pela família em uma clínica de reabilitação localizada em outro estado. No período da internação, que durou nove meses, eles não mantiveram nenhum tipo de contato.

Após receber alta do tratamento, o ex-parceiro voltou a procurar Marina. Marina conta que havia feito uma ligação ao ex-namorado, pedindo que ele fosse à casa dela consertar um objeto que anteriormente ele havia danificado. O ex-namorado chegou ao apartamento de Marina à noite, período em que ela estava em casa, e pediu para ir ao banheiro. Minha anfitriã conta que ouviu alguns barulhos estranhos vindos daquela direção e, lá chegando, encontrou o ex-namorado nu.

$\mathrm{Eu}$ perguntei se ela achou que o ex-namorado estava sob o efeito de alguma substância, ao que ela me respondeu: "Drogado ele não estava. Diz a mãe dele que ele estava louco pelo crack. Mas drogado ele não estava. Ele estava em sã consciência. Eu tenho certeza absoluta". O ex-companheiro tentou forçá-la a ter relações sexuais e, como ela tentava fugir, ele começou a machucá-la. Marina conta que ela recebeu vários puxões de cabelo, tapas e que, em certo momento, o ex-namorado estava apertando o pescoço dela, o que a impedia de respirar. Marina conseguiu se desvencilhar e gritar por socorro. Como não havia trancado a porta principal, o vizinho de Marina conseguiu entrar na casa ao ouvir os pedidos de socorro.

O vizinho conseguiu puxá-la das mãos do agressor e, imediatamente, ambos saíram do apartamento, trancando o ex-namorado dentro do local. $\mathrm{O}$ vizinho ligou para a polícia que 
chegou ao local pouco tempo depois e autuou e prendeu em flagrante o ex-namorado. Marina e o vizinho também foram para a delegacia. Ela conta que um de seus irmãos, servidor público de carreira militar, assim que ficou sabendo do ocorrido, foi imediatamente à delegacia encontrá-la e a acompanhou no registro do BO e no IML. Apesar de ter ido a uma delegacia circunscricional, Marina conta que o atendimento que recebeu "foi rápido e muito bom".

O caso de Marina chama atenção em relação a alguns fatores. Primeiro que seu excompanheiro "foi detido em flagrante", quando ainda estava na casa de Marina. Ela também contou com o apoio do seu vizinho, que a acompanhou até à delegacia e foi sua testemunha no registro da ocorrência. Outro aspecto a ser considerado é que, durante o atendimento na delegacia circunscricional, Marina estava acompanhada por seu irmão, servidor da carreira militar que atua no DF.

Esses são aspectos importantes porque, ao longo do campo, percebi, através dos relatos das minhas anfitriãs, que o atendimento que elas recebem ao acionar a LMP é permeado por circunstâncias específicas e subjetividades. Isso significa que apesar de existir uma legislação única com o intuito de assegurar as mulheres uma vida sem violência, a LMP é utilizada de maneiras diferentes. A esse respeito, Machado e Grossi (2015:572) compreendem que "a implementação da Lei Maria da Penha é uma tarefa permeada pelas subjetividades, crenças e formação específica das/os agentes de segurança e justiça em questão”.

A questão é que diferentes tipos de atendimentos podem significar diferentes perspectivas sobre a eficácia do atendimento que essas mulheres receberam do sistema de justiça criminal. No próximo capítulo, abordarei as percepções das minhas interlocutoras sobre o atendimento que elas receberam ao acionar a Lei Maria da Penha. 


\title{
CAPÍTULO 04 - O olhar das mulheres atendidas sobre a lei e a justiça
}

\author{
Sino porque la violencia es el infierno común a todos los \\ que están asociados a ella. (Nadine Gordimer, Un arma en \\ casa, 1998).
}

Nos capítulos anteriores, estive preocupada em apresentar minhas anfitriãs e as diferentes trajetórias que elas percorreram até o Fórum. Destaco que apesar de todas terem sido encaminhadas para o mesmo juizado, elas acessaram serviços e atendimentos diversos. Este capítulo analisa as percepções das minhas anfitriãs sobre o atendimento que elas receberam do Poder Judiciário através do Juizado de Violência Doméstica e Familiar Contra a Mulher do Núcleo Bandeirante. Aqui, também abordo as percepções das minhas anfitriãs sobre a Lei 11.340/2006.

Antes de conhecer minhas anfitriãs, uma das minhas hipóteses iniciais sobre o contexto social que eu pretendia estudar era que as percepções das mulheres atendidas no Juizado do Núcleo Bandeirante acerca da Lei Maria da Penha e da judicialização do processo seriam semelhantes. Afinal, neste juizado foi introduzido um projeto modelo de atendimento à mulher em situação de violência e atualmente é sede do CJM/TJDFT, que tem como objetivo estabelecer "modelo de atuação judicial” baseado na atual legislação em vigor no Brasil sobre o tema.

Ao longo do campo, foi com surpresa que percebi que a relação das minhas anfitriãs com o atendimento que elas receberam ao acionar o sistema de justiça não ia de encontro às minhas expectativas iniciais. Neste capítulo, tento abordar as percepções das minhas interlocutoras sobre o atendimento que elas acessaram no judiciário e como elas avaliam a legislação.

\section{1 - As subjetividades presentes nos atendimentos}

Moore (1978) lembra que o direito é um termo complexo que agrega diversas práticas e normas, e argumenta que as sociedades não podem ser totalmente controladas pelas normas jurídicas e pelos reguladores do direito. Para Moore, existem dinâmicas específicas que estão presentes nos "reglementary processes". Esta autora defende a importância de compreender como as pessoas interpretam, manipulam e moldam as lógicas presentes nos processos que regulamentam os contextos sociais. 
Perspectiva semelhante é defendida por Claudia Fonseca (2011:17), que nos lembra que o Estado não consegue moldar os indivíduos a formas específicas de comportamentos. Cito a autora:

\begin{abstract}
É importante lembrar que as normas legais não caem no vazio. Assim, tal como Vianna (2005) nos alerta, em vez de supor que o Estado é todo poderoso, moldando os indivíduos a formas específicas de comportamento, talvez seja mais produtivo dirigir a análise para as outras ordens de normatividade - as menos formalizadas que estão constantemente interagindo, reforçando ou competindo com a legalidade oficial. A partir de sua pesquisa em processos judiciais de guarda e adoção de crianças no Rio de Janeiro, Vianna dá exemplos dessas "outras ordens" da normatividade familiar. Ao lado da retórica do tribunal sobre "direitos" e "o interesse prioritário da criança", encontram-se no pleito dos litigantes constantes alusões à "gratidão" e à "bondade". É essa "linguagem moral", sugere a autora, que constrói a "liga" entre o "poder de mando" (a autoridade legítima das cortes) e o "dever de obediência" (o reconhecimento desse poder pelos usuários), provocando ajustes de ambos lados.
\end{abstract}

Algumas das minhas anfitriãs disseram que o tratamento que receberam foi eficiente para interromper a situação em que viviam e que, caso fosse necessário, acionariam novamente os mesmos dispositivos para interromper outras situações de violência. Outras, por sua vez, relataram insatisfação com alguns dos atendimentos pelo qual passaram ao acionar a LMP. Porém disseram que, caso fosse necessário, utilizariam novamente os mecanismos previstos na Lei 11.340/2006. Em contrapartida, merece reflexão os casos em que as mulheres não se sentiram atendidas pela política pública que visa coibir a violência doméstica e familiar contra a mulher ${ }^{88}$ e, caso passassem por situações de violência semelhantes, não acionariam o sistema de justiça.

Estas percepções foram construídas a partir dos atendimentos que foram oferecidos a essas mulheres e das expectativas que elas possuíam e/ou criaram ao acionar a legislação. A questão é que a maneira como elas são atendidas pelo sistema de justiça pode ser totalmente diferente, apesar de elas acionarem a mesma legislação. Esta situação chega ao extremo de, em uma delegacia, em um curto período de tempo, ter sido oferecido atendimentos baseados em interpretações distintas da Lei 11.340/2006.

Como foi dito anteriormente, a implementação da LMP é permeada por subjetividades, pelas crenças e pela formação dos agentes de segurança e justiça envolvidos neste processo (MACHADO E GROSSI, 2015). Sobre este aspecto, retomo os casos de Alice e Carolina. As situações relatadas por elas nos ajudam a refletir sobre as subjetividades presentes nos atendimentos oferecidos às mulheres pelo sistema de justiça. Nestes casos, os

\footnotetext{
${ }^{88}$ Esta é uma das expressões presentes na Lei 11.340/2006.
} 
delegados eram diferentes e, a partir do relato das minhas anfitriãs, podemos identificar que estes profissionais possuíam posições diferentes em relação à legislação.

A questão é que essas percepções resultaram em atendimentos opostos. No caso de Alice, o delegado justifica a agressão pela qual ela passou reproduzindo os argumentos apresentados pelo agressor, além de adverti-la que aquela conduta poderia levá-la a perder a guarda das crianças. Já com Carolina, a situação foi totalmente diferente: Ela conta que a delegada a ouviu, a aconselhou, perguntou o que ela gostaria que fosse feito e determinou que o então companheiro saísse imediatamente da residência do casal.

María del Carmen Cortizo e Priscila Larratea Goyeneche, em ensaio sobre a judicialização do privado e a violência contra mulheres, lembram que estereótipos, preconceitos e discriminações também fazem parte das concepções de mundo dos policiais e operadores do direito, marcando sua conduta profissional (2010:108). Ou seja, as maneiras como as pessoas apreendem o mundo estão refletidas nas suas atuações profissionais. No caso de Carolina, provavelmente a delegada inferiu que ela estava em uma relação na qual o seu então marido poderia vir a agredi-la a qualquer momento.

Esta atitude da delegada foi totalmente adequada sob a perspectiva de Carolina, afinal atendeu aos anseios da minha anfitriã. Carolina deixa claro que a delegada a ouviu, agiu a partir das expectativas que ela expressou e considera que este atendimento foi "bom", "rápido" e que ela "não tem do que reclamar" sobre esta ocasião.

Contudo, a LMP não prevê ${ }^{89}$ que delegados decidam e/ou julguem os destinos das pessoas que acionam a legislação. A delegada, segundo as informações contidas no relato de

\footnotetext{
${ }^{89}$ Art. 10. Na hipótese da iminência ou da prática de violência doméstica e familiar contra a mulher, a autoridade policial que tomar conhecimento da ocorrência adotará, de imediato, as providências legais cabíveis. Parágrafo único. Aplica-se o disposto no caput deste artigo ao descumprimento de medida protetiva de urgência deferida. Art. 11. No atendimento à mulher em situação de violência doméstica e familiar, a autoridade policial deverá, entre outras providências: I - garantir proteção policial, quando necessário, comunicando de imediato ao Ministério Público e ao Poder Judiciário; II - encaminhar a ofendida ao hospital ou posto de saúde e ao Instituto Médico Legal; III - fornecer transporte para a ofendida e seus dependentes para abrigo ou local seguro, quando houver risco de vida; IV - se necessário, acompanhar a ofendida para assegurar a retirada de seus pertences do local da ocorrência ou do domicílio familiar; V - informar à ofendida os direitos a ela conferidos nesta Lei e os serviços disponíveis. Art. 12. Em todos os casos de violência doméstica e familiar contra a mulher, feito o registro da ocorrência, deverá a autoridade policial adotar, de imediato, os seguintes procedimentos, sem prejuízo daqueles previstos no Código de Processo Penal: I - ouvir a ofendida, lavrar o boletim de ocorrência e tomar a representação a termo, se apresentada; II - colher todas as provas que servirem para o esclarecimento do fato e de suas circunstâncias; III - remeter, no prazo de 48 (quarenta e oito) horas, expediente apartado ao juiz com o pedido da ofendida, para a concessão de medidas protetivas de urgência; IV - determinar que se proceda ao exame de corpo de delito da ofendida e requisitar outros exames periciais necessários; V - ouvir o agressor e as testemunhas; VI - ordenar a identificação do agressor e fazer juntar aos autos sua folha de antecedentes criminais, indicando a existência de mandado de prisão ou registro de outras ocorrências policiais contra ele; VII - remeter, no prazo legal, os autos do inquérito policial ao juiz e ao Ministério Público.
} 
Carolina, cometeu excesso de poder e desvio de função ${ }^{90}$. Ainda que provavelmente a delegada tenha agido na "melhor das intenções" na tentativa de assegurar a integridade física da minha anfitriã, este tipo de ação nos ajuda a refletir sobre os limites das subjetividades presentes no acesso ao sistema de justiça.

Os casos de Marina e Ana Clara também ilustram a diferença com a qual as mulheres podem ser atendidas antes de o inquérito chegar ao Fórum. Marina, por exemplo, conta que se sentiu muito bem atendida quando foi à delegacia circunscricional que atende a sua região. Ela diz: "Na delegacia eles já passaram a medida protetiva de que ele tinha que ficar 300 metros longe de mim. Isso depois do IML. Mas, primeiro, o delegado me escutou. Os agentes recebiam a gente na entrada e depois o delegado me escutou".

De acordo com a legislação brasileira, estupro é considerado um crime hediondo ${ }^{91}$. Ainda que, felizmente, o estupro não tenha ocorrido, tentativa de estupro é algo grave e Marina possuía marcas em seu corpo da violência efetuada pelo seu ex-namorado. O intuito aqui não é desclassificar o atendimento oferecido para Marina na delegacia. Entretanto, considero importante refletir sobre características específicas do caso de Marina, que certamente contribuíram para o atendimento que ela recebeu. Neste sentido, trago à memória que no momento do atendimento na delegacia, minha anfitriã estava acompanhada do seu vizinho, que foi sua testemunha, e do seu irmão, que é servidor público de carreira militar e a acompanhou durante todo o procedimento.

Foi nessa mesma delegacia que Ana Clara foi atendida. Evidentemente, existem diferenças entre as formas de violência. Estupro é considerado um crime muito grave e a agressão física é bastante reconhecida entre as formas de violência contra mulheres presentes na LMP. No caso de Ana Clara, não havia marcas em seu corpo ou testemunhas. Aqui, é importante lembrar, que Ana Clara considera que na delegacia "não deram importância" para a sua ocorrência. Neste caso, a queixa dela foi considerada pelos profissionais que a atenderam na delegacia como "caso sem valor", um "caso de feijoada" (SOUZA, 2007).

Se Ana Clara não percebesse que sua queixa não foi tratada da maneira prevista na legislação e não estivesse atenta aos prazos para deferimento da medida protetiva o acesso dela ao sistema de justiça estaria comprometido. Chama atenção que mesmo após produzir provas contra o ex-companheiro, ela teve que insistir para ser atendida da forma como ela

\footnotetext{
${ }^{90}$ Sobre a diferença entre abuso, excesso e desvio de poder consultar: http://www.fbertoldi.com/2010/08/distincao-entre-abuso-excesso-e-desvio.html?m=1

${ }^{91}$ Art. 123 do Código Penal Brasileiro.
} 
esperava. Ou seja, que o servidor que a atendeu na delegacia ouvisse as ameaças que o companheiro fez e que ela gravou.

A questão aqui é que as subjetividades presentes na forma como elas são atendidas pelos policias e nas delegacias, comprometem o acesso dessas mulheres ao sistema de justiça, à Lei Maria da Penha e pode fazer com que elas não se sintam mais motivadas a denunciar relações e situações de violência.

A literatura sobre este tema apresenta há tempos casos sobre situações semelhantes à relatada pela minha anfitriã Ana Clara. Cortizo e Goyeneche, por exemplo, apresentam: “Temos casos onde, apesar das queixas, não são instaurados inquéritos policiais para verificar a denúncia, demonstrando o descaso e o descrédito dos policiais que lidam com esta demanda" (CORTIZO; GOYENECHE.2010:107).

Este processo também é analisado por Rifiotis (2012) que evidencia que a judicialização dos casos não significa que necessariamente as pessoas acessaram a justiça. Nas situações relatadas acima é possível identificar que apenas a legislação não é suficiente para fazer com que as denúncias sejam efetivadas.

$\mathrm{Na}$ busca por compreender as percepções das minhas interlocutoras sobre o acesso o sistema de justiça e sobre a efetividade da Lei Maria da Penha, apareceu nos relatos uma figura muito importante: o juiz. A seguir, falarei um pouco mais sobre este aspecto.

\section{2 - O juiz e a construção da percepção do atendimento pelas mulheres}

Ao longo das entrevistas, a figura do juiz foi lembrada várias vezes. Este é um aspecto interessante porque antes da audiência as mulheres são ouvidas pela equipe de atendimento multidisciplinar que trabalha naquele Juizado. Nessa ocasião elas acessam um espaço em que é permitido contar a trajetória e os detalhes sobre aqueles relacionamentos, falar sobre o que aconteceu após a judicialização do caso, ouvir orientações sobre a legislação e etc.

Já a audiência realizada com a presença do juiz, promotoria, defensoria e/ou advogados é um espaço em que elas possuem menor tempo e menos oportunidades para expressarem seus sentimentos se comparado ao atendimento que é conduzido pela equipe multidisciplinar. Mesmo assim, a figura do juiz aparece como fundamental na construção das percepções das minhas anfitriãs sobre o atendimento oferecido pelo juizado e pelo sistema de justiça como um todo.

Algumas das minhas interlocutoras falaram sobre como a autoridade transmitida pelo juiz contribui para que expectativas sejam atendidas. Ouvi afirmações dizendo que o juiz "deu 
uma chamada" no agressor, outras disseram que o magistrado perguntou o quê elas gostariam "que acontecesse com o processo". Conceição, por exemplo, considera que a audiência com o juiz "funcionou" porque deixou o seu ex-marido "com medo":

O juiz chegou a perguntar pra mim, na frente dele, se eu queria que ele fosse preso. Quando chegou no final da audiência ele falou que a decisão era minha. E eu disse que não queria que ele fosse preso, só queria que ele mudasse. E do jeito que ele estava, com a cabeça baixa, ele ficou.

Conceição também faz um paralelo entre o atendimento que ela recebeu ao acionar a Lei Maria da Penha e o atendimento que ela recebeu quando denunciou o mesmo ex-marido antes da promulgação da LMP. Ou seja, naquela ocasião o processo foi encaminhado aoJECrim. Aqui, ela volta a dizer que a Lei Maria da Penha "funcionou", ou seja, atendeu as suas expectativas, as suas demandas. Cito a fala da minha anfitriã: "Porque assim, antigamente o processo não ia dar em nada. E hoje chegou até o extremo, como ele viu, quando o juiz me perguntou se eu queria que ele fosse para a cadeia. Ele viu que eu poderia fazer isso. Chegar a esse ponto dele poder ir para a cadeia”.

Já Lorena, conta que estava receosa sobre ir à audiência porque até iniciar este processo, ela nunca havia ido ao Fórum. Ela conta que não sabia como ela deveria se comportar naquele novo ambiente e que estava "morrendo de medo". Minha anfitriã ressalta que o juiz foi importante para que ela se sentisse atendida:

O juiz foi maravilhoso, atencioso, muito educado (risos). Ele não apoiou o meu marido em momento nenhum. Então ele foi mais a meu favor, todo o tempo (...). Às vezes, o meu marido começava a falar alguma coisa, que você via que ele estava mentindo e aí o juiz falava "não", me fazia as perguntas e eu respondia.

Minha anfitriã lembra que foi no momento em que seu marido "prometeu na frente do juiz que não ia mais beber e ia procurar tratamento" que ela acreditou que as coisas iriam mudar. E Lorena conta que, de fato, após a audiência seu companheiro procurou tratamento para pessoas alcoólicas.

Nessa perspectiva, minha interlocutora Rachel conta que foi na presença do juiz que ela acha que "adiantou mais". Peço para que ela conte mais detalhes e Rachel diz que se sentiu "mais segura" no momento da audiência do que no atendimento com a equipe e que naquele espaço, percebeu que suas demandas seriam atendidas:

Eu falei mais na presença do juiz. Acho que funcionou mais, me senti mais segura, mais confiável de falar com o juiz. Eu confiei mais no juiz, então para mim adiantou 
mais. Quando você vai conversa com o juiz você sente mais forte, sente que vai adiantar alguma coisa. Mas meu ex falava mais que eu, eu não cheguei a falar muito, muito não (...). Ele não olhava para minha cara. Eu acho que ele estava morrendo de medo, porque às vezes eu olhava e a mão dele estava tremendo.

Nos relatos em que as mulheres citam especificamente a atuação do juiz, ele aparece como a figura de autoridade, capaz de mudar trajetórias de vida dessas mulheres a partir daquele momento. Neste sentido, Ana Clara conta que o juiz orientou o seu ex-companheiro a fazer o acompanhamento com o psicossocial. Ela diz que na audiência, o magistrado alertou seu ex-companheiro sobre as penas previstas na legislação e que, caso ele não cumprisse o que estava sendo determinado, “o juiz iria tomar uma providência maior”. Por sua vez, minha interlocutora Lia destaca uma ação do juiz perante seu ex-companheiro no momento da audiência: "o juiz sempre colocava ele contra a parede".

É interessante a perspectiva das mulheres sobre o juiz. Aqui, a figura do juiz aparece como alguém que as ouve e que, ao final da audiência, pergunta as mulheres o que elas gostariam que acontecesse. Essa prática é bastante diferente das práticas estudadas por Regina Lúcia Teixeira Mendes (2012:471), em seu estudo sobre o processo decisório judicial brasileiro visto a partir de uma perspectiva empírica.

A autora revela que alguns juízes valorizam o contato com a parte na tentativa de não se deixar levar apenas pelos discursos produzidos pelos advogados. A autora ressalta que "no entanto, essa participação serve para trazer elementos para o juiz decidir, uma vez que também é claro no discurso que é o juiz quem sabe qual é a melhor forma de solucionar o conflito" (idem).

Mas segundo relatos das minhas anfitriãs, na audiência que ocorre no Juizado de Violência Doméstica e Familiar do Fórum do Núcleo Bandeirante, o atendimento é diferente do que Teixeira Mendes apresenta. Diferentes interlocutoras trazem a informação de que no momento da audiência, o juiz pergunta o que elas queriam que acontecesse com o agressor, o que elas gostariam que ele, o juiz, fizesse. Aqui, ao que parece, as mulheres podem decidir sobre o que elas desejam para a vida delas.

Esta é uma situação inovadora. Como veremos a seguir, as mulheres se apropriam de diferentes maneiras da Lei Maria da Penha. Em alguns casos, s mulheres se apropriaram da legislação como recurso de poder dentro do relacionamento, buscando influenciar o comportamento de seus companheiros. Isso é bastante comum nos casos em que as mulheres relatam que não queria que os companheiros fossem detidos. 
Nessas situações o relato é de que elas gostariam que seus companheiros mudassem o comportamento e não praticassem mais ações violentas contra elas. Uma das minhas anfitriãs, que reatou o relacionamento com o companheiro que a agrediu, é Alice. Ela conta que na ocasião da audiência, o juiz perguntou o quê ela queria e ela disse que gostaria que o caso fosse arquivado. $\mathrm{O}$ caso foi arquivado, eles estão juntos e ela conta que se sentiu atendida pela LMP porque o seu marido parou de agredi-la e reviu esse tipo de comportamento.

Nos casos descritos pelas minhas anfitriãs, muitas relatam que se sentiram atendidas e satisfeitas com a justiça e com a LMP porque o juiz as ouviu e perguntou o que elas queriam. Principalmente nos casos em que elas permanecem no relacionamento afetivo-amoroso, é possível perceber que elas se apropriaram da legislação para estabelecer novos limites, que elas consideram aceitáveis, para o relacionamento. Aqui, o papel desempenhado pelo juiz é fundamental porque o magistrado parece perceber que muitas das demandas levadas pelas mulheres para a audiência não seriam satisfeitas se ele apenas aplicasse "a letra fria da lei". Nesses casos, provavelmente elas não considerariam que a "justiça foi feita" ou que "a lei serviu" porque as demandas delas, nos casos das mulheres que acionam a legislação no intuito de mudar o comportamento dos seus companheiros, não seriam atendidas.

A figura do magistrado como alguém "bondoso", "firme", "atencioso", "educado", responsável por deixar os homens "no seu lugar" é construída quando o juiz escuta as demandas dessas mulheres, mostra autoridade perante aos agressores e pergunta o que as mulheres desejam que ele, o magistrado, faça. Ou seja: como elas querem ser atendidas.

A seguir, falarei sobre as diferentes expectativas das mulheres sobre a legislação.

\section{3 - Sobre diferentes expectativas e uma única legislação}

Não é apenas o atendimento que as minhas anfitriãs receberam ao acessar o Estado que contribui para as percepções delas sobre a Lei Maria da Penha e sobre o sistema de justiça. Com o campo, percebi diferenças sobre o que minhas interlocutoras gostariam que acontecesse em suas vidas quando elas acionaram a legislação. As expectativas sobre o quê elas esperavam do sistema de justiça eram diferentes, às vezes opostas.

Como disse anteriormente, enquanto algumas queriam que o então companheiro fosse preso, outras gostariam que a justiça fosse capaz de mudar o comportamento e as ações praticadas pelo homem em questão. Acontece que isso não significa, necessariamente, que elas quisessem terminar o relacionamento. 
Minha anfitriã Lia vivia um relacionamento extremamente conturbado com o seu excompanheiro. Frequentemente ela vivia situações em que a violência se apresentava através de várias formas: insultos, agressões físicas, ameaças... Conversamos sobre as expectativas que ela tinha na primeira vez que decidiu denunciar o ex-companheiro:

Krislane: - Então o quê você acha que você queria nessa época? Lia: - O quê eu queria na verdade é que ele parasse de me bater. Que alguém parasse ele. Krislane: Mas você não queria separar dele? Lia: - Era, era. Krislane: Então você queria que ele parasse de te agredir, de te bater, mas não queria terminar com ele? Lia: - É. Era isso. Eu não queria separar. Era isso mesmo. Não adianta se enganar, é a verdade.

Lia me explica que quando procurou o sistema de justiça, seu intuito não era se separar. O que ela queria é que seu então ex-marido mudasse seu comportamento e suas ações, para que ela pudesse viver uma vida sem violência. Mas ao lado dele. Lia me explica:

\begin{abstract}
Krislane: - O quê você queria quando decidiu ir à delegacia? Lia: - Eu queria que ele fosse penalizado mesmo. Mas aí cada vez não acontecia nada, só tinha audiência e não acontecia nada. Para mim, eu achava que funcionou mesmo foi da primeira vez. Por isso que muitas vezes eu tirei, porque eu tinha medo também dele ser preso. Eu morria de medo também. Acontece isso, sabia? Você é agredida e fica com medo de denunciar a pessoa que te bateu. Krislane: - Você estava com medo porque você achava que ia acontecer dele ser preso? Lia: - Porque eu achava que ia acontecer! Krislane: Você ficava com medo que ele te ameaçasse? Lia: - Não. Krislane: - De que ele fosse preso? - Lia: - De que ele fosse preso! Krislane: - Então você não queria que ele fosse preso? Lia: - Eu queria e não queria. Sabe como é que é? $\mathrm{Na}$ hora você quer, mas depois... Na hora que está lá (na audiência) aí você não quer mais não. Por isso que eu estou te falando, é complicado. Krislane: - Quando você ia à delegacia, você queria que ele fosse preso. Lia: - Era. Eu queria que ele fosse punido, de alguma forma. Ele estava me batendo, me agredindo, alguém tinha que parar ele. Era a polícia, era a justiça. Porque meus irmãos não se envolviam, eu não tinha amigos para me defender, eu não tinha meu pai para me defender. Então eu achava que a única forma de ele parar de me bater era denunciando ele. Que a justiça ia me ajudar, que a lei ia me ajudar. Krislane: - E depois você mudava de opinião, aí você não queria que ele fosse mais preso... Lia: - Era... Depois que aconteceu, que eu denunciava ele, que eu via que ia pegando mesmo, eu ficava com dó dele. Dó. Olha só. Aí depois eu ficava com raiva porque eu ia lá e tirava e acontecia de novo. Krislane: - Ele te pedia para tirar? Lia: - Não. Eu mesma ia tirar. É tipo assim, emocionalmente. Krislane: - Ele chegou a te pedir alguma vez? Lia: - Não. Isso não. Só para eu não ir nas audiências. Ele pedia para eu não ir nas audiências. Aí eu ia. Se eu tinha feito a ocorrência eu ia faltar na audiência? Não podia.
\end{abstract}

Minha interlocutora conta que temia que o ex-marido fosse preso, porque na época ela desejava que eles conseguissem preservar o relacionamento e a família. Ela conta que sempre que pensava que o então marido poderia ser preso, ela pensava no bebê do casal. E por isso, em momentos que o relacionamento do casal estava bem, ela retirava a queixa. 
Em uma das audiências em que o casal compareceu, Lia recorda que o juiz "perguntou se a gente queria separar e a gente disse que não, que a gente queria tentar uma reconciliação e tal, que a gente tinha um bebê". Ela me explica que nessa ocasião o processo "estava semiaberto. Não sei se arquiva, não sei como é que é. Só sei que se acontecesse alguma coisa eu poderia ir à delegacia e automaticamente já ia para o Fórum”.

Minha interlocutora se apropriou deste discurso e passou a utilizá-lo com o intuito de que o ex-marido mudasse seu comportamento violento. Lia relata: - Eu falava assim 'você sabe o quê tem lá no processo, né? Você sabe!' Eu usava isso. Era como uma arma que eu tinha para me defender, para ele não tocar em mim.

Nadine, uma das minhas anfitriãs, apresentou perspectiva diferente da que foi contada por Lia. No caso de Nadine, ela havia acionado a LMP em dois momentos distintos, com dois parceiros diferentes. Nadine conta que nos dois casos, a influência da sua rede afetiva foi importante para que ela denunciasse a situação pela qual passou. No primeiro caso, a mãe de Nadine insistiu para que ela registrasse ocorrência enquanto no segundo caso ${ }^{92}$ foi seu excompanheiro, que ela havia denunciado no processo anterior, que insistiu para que eles fossem à delegacia.

Ela conta que no decorrer do primeiro processo, principalmente após os atendimentos com o serviço psicossocial, o seu ex-namorado mudou muito o comportamento. Sobre este aspecto, Nadine relata: “-Hoje em dia ele é uma outra pessoa. Ele não discute comigo, não tenta falar nem alto comigo, de xingar, igual ele fazia antes, ele não fala. Agora eu não sei se é por medo de eu fazer alguma coisa ou porque ele se tocou também”.

Eu pergunto sobre as percepções dela sobre a LMP, especificamente em relação ao primeiro processo e Nadine considera que a legislação e o sistema de justiça foram eficientes porque fizeram com que seu ex-parceiro mudasse seu comportamento. Em relação ao segundo processo, minha anfitriã conta que embora tenha sido seu ex-companheiro quem a incentivou a registrar a ocorrência, ela considera que ter ido à delegacia registrar ocorrência foi importante. Nadine diz que espera que, neste caso, seu ex-namorado também repense suas ações. Cito minha interlocutora:

Krislane: - E o quê você espera que aconteça nesse segundo caso, no segundo processo? Nadine: - A mesma coisa. Que pelo menos ele entenda que não pode fazer isso porque deu vontade. Que ele entenda igual ao I. entendeu. Que as coisas

\footnotetext{
92 Lembrando que consegui contatar Nadine através dos dados que estavam no arquivo do Fórum, pois o $1^{\circ}$ processo já havia sido encerrado. O segundo processo ainda estava em estágio inicial, Nadine ainda não havia comparecido ao Fórum, seja para o atendimento com a equipe multidisciplinar, para a audiência ou para participar das reuniões com a equipe psicossocial.
} 
não funcionam do jeito que eles querem, né. (...) E eu quero que ele (o segundo agressor) também mantenha distância.

Já minha anfitriã Clarice não tinha expectativas positivas em relação à Lei Maria da Penha porque ela achava que a LMP "não ia ter muito resultado, que não ia valer nada". As expectativas de Clarice foram se transformando com o andamento do processo. Sobre esse aspecto, Clarice disse compreender que o atendimento que acessou funcionou como uma espécie de "parceria". Minha anfitriã explica que a delegacia, o conselho tutelar, o Juizado de Violência Doméstica e Familiar contra a Mulher e a Vara Cível, Família, Órfãos e Sucessões agiram em conjunto para que ela não sofresse mais ameaças e agressões psicológicas, obtivesse a guarda de Joana. Neste momento, Joana diz que "a justiça fez muito mais do que a gente esperava". É oportuno citar:

Eu fui aprendendo, fui lá nas reuniões e eu vejo que foi essencial. E não é só para mim, é para todas as mulheres que precisarem da Lei. Tem que procurar a justiça, porque realmente é verdade. E eu não acreditava. Hoje eu estou mais segura, porque antes eu não procurava, eu nem sabia que existia tanta coisa assim a meu favor.

Clarice relata que demorou apenas seis meses, a contar do registro do BO, para que ela conseguisse a guarda absoluta da neta e que considera que esse fato reflete a eficiência do sistema e a agilidade com a qual suas demandas foram tratadas. Nestas situações, minhas interlocutoras relatam que tiveram suas demandas reconhecidas e que o sistema de justiça as tratou com respeito e consideração. Sobre este aspecto, cito:

O reconhecimento, ou o direito de ser tratado com respeito e consideração, é o aspecto que melhor expressaria a dimensão moral dos direitos (...). Nos casos em que a reparação a este tipo de ofensa é suficientemente embutida nas deliberações judiciais sobre as outras duas dimensões temáticas dos conflitos (direitos e interesses), os tribunais promovem um desfecho satisfatório para as respectivas causas (CARDOSO DE OLIVEIRA, 2010:461).

Minha anfitriã Lygia possuía expectativas iniciais totalmente diferentes das expectativas apresentadas por Lia, Nadine e Conceição. Lygia conta que achava que no momento em que denunciasse o companheiro, ele seria preso. E para ela, isso significava a chance de recomeçar uma vida sem situações de violência doméstica. Ela me diz que em situações anteriores ela não havia denunciado o marido por temer que o "pai do seu filho" fosse preso. E essa era uma certeza que ela tinha: que quando acionasse a LMP os policiais iriam prender seu marido. 
Após a briga ${ }^{93}$, os policiais chegaram e o companheiro de Lygia já não estava mais no local. Ela contou sobre o ocorrido, mas os policiais disseram que a única coisa que poderia ser feita seria levá-la até à delegacia para que ela registrasse o BO. Esse é um aspecto importante porque na perspectiva de Lygia, os policiais “também fizeram pouco caso disso". Lygia diz: "Eu pensava que eu ia chamar a polícia e ele ia ser preso. (...) Eu achava que era assim, que era mais rápido, que era uma coisa certa”.

A frustração de Lygia com o atendimento aumentou ao longo do processo. Apesar de o marido não ter sido preso, ela tinha expectativas de que o marido mudasse o seu comportamento agressivo e a deixasse "viver em paz", respeitando sua opção de não querer mais fazer parte daquele relacionamento. Mas com o desenrolar do caso, suas expectativas não foram atendidas e ela percebeu que a maneira como o Estado tratava suas queixas tornava toda a situação burocrática e, não necessariamente, resolvia o problema.

Após Lygia ter registrado o BO e ter se mudado com o filho para a casa em que seus pais moravam, minha anfitriã resolveu se separar do companheiro. Lygia conta que o marido tentava controlá-la pelo celular e a seguia constantemente. Aqui, entra outro conflito: Lygia não queria mais que "o pai do seu filho" fosse preso e, por isso, não o denunciou por descumprir as medidas protetivas:

Lygia: - Assim de acontecer e você chamar a polícia não dá nada. Aí você procura a
delegacia da mulher, aí tem esses papeis todinhos, que até você se enrola. Você se
enrola todinha nisso e até eles fazerem alguma coisa... Aí dão essa medida protetiva,
mas se o homem for muito doido mesmo, o cara te mata. Se ele tivesse que me matar
ele teria matado. Krislane: - Você acha que a justiça te ajudou, ajudou a apontar
algum caminho para a sua vida? Lygia: - Não. É que nem eu te falei, se ele tivesse
pelo menos ficado balançado com tudo isso... Krislane: - Você também estava
falando sobre as medidas protetivas... Lygia: - Elas não funcionaram. Mas eu acho
que não funcionaram porque eu não ajudei muito, né. Mas até eu ligar e a polícia
chegar, é um século. Já deu para o cara fazer muitas coisas. Eu já tinha morrido
umas dez vezes.

O companheiro de Lygia soube utilizar a crescente frustração que minha anfitriã sentia a seu favor. Ela se decepcionou com o fato de ter sido encaminhada para as reuniões conduzidas pelo serviço psicossocial do Fórum. A seu ver, quem deveria participar das reuniões era o marido: “Quem fez foi ele! Então por quê é que eu tenho que estar lá?” $\mathrm{Na}$ época, ela se esforçou para ir aos primeiros encontros, pedindo dispensa no trabalho, mas desistiu de participar das sessões quando o marido, que nunca compareceu às sessões, fez

\footnotetext{
${ }^{93}$ Este episódio foi relato no capítulo anterior.
} 
chacota com o fato de ela ter sido agredida e ter que comparecer as reuniões. Lygia conta que isso contribuiu para que ela ficasse "mais revoltada".

Minha interlocutora conta que reatou o relacionamento com o marido porque sua vida "estava virando um inferno". Além de lidar com perseguição do companheiro, Lygia disse que seus pais já não aguentavam mais a situação. Por medo de que acontecesse uma tragédia, ${ }^{94}$ ela aceitou reatar. Durante nossa conversa, fiquei emocionada quando Lygia contou que durante todo o relacionamento, aquele era o único momento em que ela não foi agredida. Em seguida, ela completa: "Mas eu sei que quando eu parir vai voltar tudo de novo. Eu sei que vai voltar (..). Eu não acredito que ele vá mudar" 95 . Sobre as percepções de Lygia sobre a LMP, cito:

Krislane: - Você se sentiu atendida pela Lei? Lygia: - Não. Krislane: Se fosse necessário você procuraria a Lei novamente? Lygia: - Não, porque para mim é como eu te falei... A minha visão é que o jeito é eu me conformar (...). Eu me conformei. Não que eu goste de apanhar, como muita gente já me falou, que eu gosto de apanhar. Krislane: - Eu imagino que não.

Ao final, Lygia me diz que se pudesse dar um conselho para alguém que estivesse em uma situação semelhante a que ela passou, não indicaria "procurar" a LMP porque "a justiça só piorou a situação" $"$.

A perspectiva apresentada pela minha anfitriã Carolina possui vários pontos em comum com a percepção de Lygia sobre o acesso ao sistema de justiça e sobre a Lei Maria da Penha. Eu pergunto se Carolina indicaria a Lei Maria da Penha para alguma mulher que passasse por uma situação semelhante a que ela passou e Carolina me surpreende com a resposta:

\footnotetext{
${ }^{94}$ Lygia me explica que tinha muito medo que seu pai e seu marido se encontrassem e brigassem por conta de toda aquela situação. Ela disse que acha que poderia "acontecer uma tragédia", porque os pais dela também não suportavam mais a situação.

95 Conhecer Lygia, a situação em que ela vivia e a certeza que ela tinha que continuaria passando por situações de violência assim que a gravidez terminasse mexeu com muitas das minhas sensibilidades. Após a entrevista, conversamos sobre ela denunciar novamente aquela situação e ela se mostrou totalmente relutante. Eu anotei meu número de celular na cópia do 'termo de confidencialidade e sigilo' que ficou com Lygia e disse que se ela decidisse acionar novamente o sistema de justiça eu poderia acompanha-la, caso ela permitisse. Lygia disse que ia guardar o termo na casa dos pais dela e que pensaria sobre o assunto. Cerca de uma semana após a entrevista, eu liguei novamente para Lygia, para saber como ela estava. Ela me disse que estava tudo bem e pediu que eu não entrasse em contato novamente, que ela tinha o meu número. Respeitei a decisão de Lygia.

${ }^{96}$ Lygia conta que alguns meses após ela ter optado por arquivar o processo, servidores lotados no Juizado ligaram para ela com o intuito de saber como ela estava e se havia acontecido algum outro fato relacionado a violência doméstica e familiar após o arquivamento. Lygia diz que nessas ocasiões dizia que "estava tudo bem". Quando eu a questiono sobre os motivos pelos quais ela fazia essa afirmação, ela me diz que não acreditava que
} 
Eu falaria para ir para Igreja. Vai para Igreja e ora. Porque se for para a justiça não vai dar em nada. Em nada mesmo. É o que eu estou fazendo. Depois que eu vi que a justiça não ia fazer nada por mim eu fui para a Igreja. Fui procurar ajuda em Deus, conversar com Deus.

Porém, ao contrário de Lygia, Carolina considera que sua primeira ida à delegacia foi muito satisfatória. Com a boa experiência que teve, minha anfitriã alimentou expectativas de que a Lei Maria da Penha impediria seu ex-marido de se aproximar. Nesse ponto, Carolina destaca que esperava que a legislação a ajudasse a solucionar questões que ficaram pendentes com o término do relacionamento. Porém, as situações que ela relata não necessariamente estavam ligadas às situações de violência doméstica pelas quais ela passou.

Minha anfitriã imaginou que a lei poderia auxiliá-la no divórcio e na divisão dos bens que o casal tinha em comum, faria com que o ex-companheiro pagasse em dia a pensão alimentícia dos filhos do casal e o manteria afastado. Contudo, ela conta que nada disso aconteceu. Carolina conta que devido a estes motivos, ela não pensa em procurar justiça novamente. Aqui, o discurso de Carolina se aproxima com o de Lygia em relação à frustração que ambas sentem com a judicialização do processo. Carolina diz que, atualmente, não pensa mais em procurar a justiça, mesmo se passasse por situações semelhantes:

Eu fui e não deu em nada. Ninguém vai atrás dele, ninguém conversa com ele, ninguém chama. Eu não iria de novo. Se ele voltasse a perturbar de novo, eu não iria. Porque eu sei que não tem solução. Parece que é pouco para a justiça as agressões sexuais, psicológicas, verbais. Não funciona. Essa lei só funciona para quem tá nas últimas (...). É canseira, canseira. Eu não iria. Se ele voltasse a me perturbar de novo eu não iria nem me mover, gastar meu tempo para ir à delegacia fazer queixa, ir lá no Fórum.

Carolina ressalta que não iria acionar a Lei Maria da Penha porque ela considera que nos momentos em que precisou, ela não recebeu o atendimento que esperava. $\mathrm{O}$ processo burocrático que enfrentou ao procurar o Estado também é alvo de críticas. Como exemplo, minha interlocutora resume o atendimento que recebeu quando foi à delegacia após o exmarido ter saído de casa: “É perder tempo. Ficar lá, chegar lá, anotar um monte de dados. Eles vão, imprimem um papel e te mandam para casa. Pronto, é esse o atendimento".

No relato de Carolina, a legislação aparece como um mecanismo que burocratizou a vida dela, mas que não serviu para concretizar as demandas que ela esperava quando acionou a Lei Maria da Penha. Ela não conseguiu que o marido se afastasse totalmente com as medidas protetivas de urgência, não teve acesso aos serviços policiais da maneira que ela 
esperava. Mas é oportuno destacar que nem sempre as demandas das minhas anfitriãs podem ser solucionadas através da $\mathrm{LMP}^{97}$. Carolina gostaria que essa legislação servisse também para ajuda-la no processo de divórcio, mas isso não ocorreu. Outra questão é que Carolina acusava o ex-marido de ter cometido violência patrimonial, pois segundo o relato dela, seu ex-parceiro havia vendido bens construídos pelo casal ao longo do relacionamento. Estes bens, no entanto, não estavam registrados no nome dela ou do casal e por isso, ela não possuía provas materiais de que o marido havia cometido estas ações, o que fez com que ela não conseguisse ter suas expectativas atendidas.

Aqui, Carolina sente que foi desrespeitada pela legislação, pelos procedimentos burocráticos e pela justiça. Sobre este aspecto, recorro ao conceito de insulto, utilizado por Cardoso de Oliveira (2008:136-137):

(...) segundo Strawson, o ressentimento da vítima nesse tipo de situação provocaria um sentimento de indignação moral em terceiros que tivessem presenciado o ato e capitado a intenção do agressor, dando assim substância ao caráter objetivo da agressão. Evidentemente, quando falamos em sentimentos no plano moral, dirigimonos àqueles sentimentos social ou intersubjetivamente compartilhados. $\mathrm{O}$ insulto aparece então como uma agressão à dignidade da vítima, ou como a negação de uma obrigação moral que, ao menos em certos casos, significa um desrespeito a direitos que requerem respaldo institucional.

Nos casos relatados por Carolina e Lygia, a legislação não foi suficiente para atender as expectativas dessas mulheres. Além disso, elas relatam que se sentiram ofendidas em vários momentos em que acionaram o sistema de justiça, porque na perspectiva apresentada por essas mulheres, as demandas e anseios delas não foram tratados com consideração. Nestas situações, elas não consideram que houve uma reparação por parte do Estado. Sobre a reparação, é oportuno citar (2008:139):

\begin{abstract}
A reparação frequentemente demandaria ainda processos de elucidação terapêutica do ponto de vista da vítima. Não me refiro a processos terapêuticos em sentido estrito, como um padrão, mas à necessidade de repor os déficits de significado provocados por agressões arbitrárias, vividas como uma negação do eu ou da persona da vítima, e cujo caráter normativamente incorreto e merecedor de sanção social negativa tem que ser internalizado pela vítima para que sua identidade de pessoa moral, digna de estima e consideração, seja resgatada.
\end{abstract}

\footnotetext{
justiça novamente.

${ }^{97}$ Entre os objetivos da Lei Maria da Penha está a criação de mecanismos para punir e coibir a violência doméstica e familiar contra mulheres. Destaco este aspecto porque Carolina imaginava que todos os problemas e situações relacionados ao ex-marido seriam resolvidos no Juizado de Violência Doméstica e Familiar contra a Mulher. Porém, algumas dessas demandas são competências de outras varas/juizados.
} 
Quando Carolina e Lygia afirmam que não acionariam a legislação novamente, elas relatam diversas frustrações que foram construídas ao longo de todo o atendimento oferecido a elas pelo sistema de justiça criminal. Nestes casos, não houve reparação adequada e os desfechos judiciais foram considerados insatisfatórios do ponto de vista das minhas anfitriãs (CARDOSO DE OLIVEIRA, 2010:461). Esse conjunto de frustrações, demandas não solucionadas, expectativas que não foram atendidas e a não reparação desses sentimentos por parte do Estado faz com que elas procurem outras instituições, como igrejas, para se sentirem amparadas ou passem a considerar que é preciso "se conformar" com a negação de direitos e com uma vida em que a violência se apresenta de diversas formas.

\section{4 - Sobre a decisão de arquivar o processo}

A decisão de arquivar o processo aparece sob diferentes pontos de vista. Carolina e Lygia argumentam que ter acionado a Lei Maria da Penha não fez com que suas demandas iniciais fossem atendidas. Ao contrario, ao longo de todo o processo de judicialização, elas foram se frustrando cada vez mais com o sistema de justiça. Essa frustração, fruto do não reconhecimento de demandas, fez com que essas mulheres não encontrassem mais sentido em seguir com o processo.

A decisão de arquivar o processo é compreendida de formas diferentes em outros casos. A decisão de arquivar o processo significa interromper ou desistir de dar prosseguimento ao caso. Todavia, com o trabalho de campo percebi que a decisão de arquivar o processo também é compreendida pelas minhas interlocutoras como uma maneira que essas mulheres possuem para controlar seus próprios destinos.

Marina, por exemplo, conta que ao longo do andamento do processo ela mudou de opinião em relação ao que queria inicialmente. Ela diz que quando foi à delegacia queria "que ele ficasse preso pelo resto da vida". Porém, durante período em que o processo estava tramitando, o problema "já tinha solucionado". Ela diz: "Fui eu que pedi. Eu que pedi, eu que solicitei o arquivo porque eu estava muito... Como é que se diz... Aquela situação já estava me desgastando muito e eu não queria... ficar remexendo, lembrando coisas que já tinham solucionado".

Ana Clara relata que ela e o ex-companheiro foram encaminhados para o atendimento oferecido pelo serviço psicossocial do Fórum e que ambos compareceram em todas as sessões. Segundo Ana Clara, ao longo de todo esse processo, o ex-companheiro mudou seu comportamento e nunca mais a ameaçou ou praticou qualquer ato violento contra ela. Certa 
ocasião, após ambos terem participado dos atendimentos oferecidos pelo psicossocial, o exmarido ligou para Ana Clara e perguntou se ela poderia arquivar o processo. Minha interlocutora conta que todo esse quadro foi importante para a decisão que ela tomou:

\begin{abstract}
Aí, depois, me chamaram no Fórum novamente, aí eu compareci e perguntaram se eu queria seguir em frente com o processo. Como ele tinha me ligado... Bom, aí eu expliquei para ela que ele tinha me ligado me pedindo isso e como não houve mais ameaça, então eu queria retirar, eu queria pausar o processo. Aí ela me deu o suporte, explicou tudinho, que seu eu parasse ali e depois de seis meses se eu quisesse e tal.
\end{abstract}

Ana Clara conta que em sua decisão ela considerou que a sua demanda havia sido solucionada. Minha outra interlocutora, Alice, tem opinião parecida. Alice considera que a "justiça foi feita" porque de certa forma o marido "foi punido" e, sobretudo, porque ele mudou seu comportamento.

Segundo Alice, essa mudança foi fundamental para que eles reatassem o relacionamento e permanecessem juntos. Minha anfitriã conta que na audiência, a justiça acatou o que ela queria naquele momento: que o processo fosse arquivado. É oportuno citar:

\begin{abstract}
No meu caso a justiça foi feita porque, de certa forma, ele foi punido. Só não foi mais porque eu não quis. E porque eu quis que arquivasse o processo e tudo mais. Mas, se eu quisesse, eu acho que teria sido sim. Eu não sei qual que seria a punição, se seria cadeia ou pagar cestas básicas, mas eu acho que seria sim. $\mathrm{O}$ tratamento em grupo, ele fez também. Eu acho que a justiça foi feita porque ela conseguiu fazer que ele mudasse. E ele mudou. Não vou dizer que hoje em dia a gente não discute, porque a gente discute. Mas quando um percebe que o outro está mais alterado, ou eu saio ou ele sai. A gente deixa o outro falando sozinho. No meu caso a lei ajudou sim.
\end{abstract}

Hilda também decidiu arquivar o processo. Ela me conta que desde o momento em que registrou ocorrência contra o ex-marido, já sabia que "não ia ter punições severas, que ele não ia ser preso". Mas aqui Hilda afirma que ela conseguiu o que queria: que ele a respeitasse, que não a agredisse. Ela diz que ao acionar a Lei Maria da Penha esperava que "desse um basta ali naquele momento, que ele visse que tem que me respeitar". Eu questiono se ela queria que ele fosse preso. Hilda diz: - Não. Eu nunca quis. Eu queria que ele tivesse um freio, que ele não fizesse mais aquilo.

O caso apresentado por Lorena é um pouco diferente. Minha anfitriã conta que após o marido ter ficado detido, ele passou a ter medo da lei. Minha interlocutora diz que o marido nunca falou sobre o que aconteceu quando ele estava detido e não gosta que toquem nesse assunto. Lorena entende que a prisão funcionou "como uma lição" e diz que se o marido não 
tivesse sido detido eles "continuariam naquela mesma história, no mesmo lugar de sempre, e, no final das contas, foi bom ele ter sido preso".

A questão é que Lorena não gostaria que ele permanecesse preso $^{98}$ ou que seu marido fosse preso mais uma vez. Por isso ela optou por arquivar o processo. Para Lorena, após o período em que ficou detido, seu cônjuge "melhorou", ou seja, mudou o seu comportamento.

Lorena: - A Lei ajudou muito. Mudou o pensamento dele. A minha vida mudou. Os meus parentes não vinham na minha casa e hoje eles vêm. Krislane: - Por quê? Lorena: - Porque ele bebia e quando ele chegava ele xingava todo mundo. Quando ele chegava bêbado ele se transformava. Era outra pessoa. Por isso que eu acredito na justiça. Porque me ajudou. Primeiramente é Deus, mas a justiça foi enviada de Deus para me ajudar. Eu acho que se muitas mulheres que sofrem fossem, melhoraria. Porque às vezes não vai porque tem medo, né.

Lorena considera que após a audiência em que o marido se comprometeu com o juiz a procurar atendimento especializado para pessoas alcoólicas e que ela decidiu arquivar o processo, a vida da família melhorou consideravelmente. Minha anfitriã conta que depois dessa audiência ela "confiou" no marido e que ele conseguiu um "emprego fichado", o que contribuiu para que a renda da família aumentasse consideravelmente.

Evidentemente estas perspectivas devem ser consideradas em seu contexto. O Juizado de Violência Doméstica e Familiar contra a Mulher localizado no Fórum do Núcleo Bandeirante tem um histórico pioneiro em atender as mulheres em situação de violência de forma diferenciada. Além disso, o número de casos atendidos por dia também deve ser levado em consideração.

O Juizado de Violência Doméstica e Familiar contra a Mulher do Núcleo Bandeirante é caracterizado por atender regiões do Distrito Federal com baixo número de habitantes (comparado a outras regiões do DF) ${ }^{99}$. Este é um dos fatores que fazem com que este juizado consiga, por exemplo, ter em média cinco audiências diárias, enquanto em outras regiões este número tende a ser significativamente maior. Este é um aspecto importante porque com um menor número de audiências é possível que juízes, promotores, defensores, etc., dediquem mais tempo aos processos e possam ouvir as narrativas apresentadas pelas partes.

\footnotetext{
${ }^{98}$ É oportuno relembrar que Lorena conta que o marido foi detido por alguns dias porque ele a ameaçou na frente do delegado.

99 Os dados referentes as RA’s atendidas pelo Fórum do Núcleo Bandeirante mais recentes (ano 2015) não estavam disponíveis no site http://www.codeplan.df.gov.br/component/content/article/261-pesquisassocioeconomicas/319-pdad-2015.html. A Pesquisa Distrital de Amostra de Domicílios do Distrito Federal (PDAD/DF-2011) informa que a população residente na Candangolândia é de 15.953 pessoas, a população residente no Núcleo Bandeirante é de 22.569 pessoas e a população residente no Park Way é de 19.648 pessoas. Não consegui acessar dados mais recentes produzidos pelo PDAD. Consultado em 11/08/2015.
} 
Pasinato (2004:16) afirma que as delegacias de defesa da mulher e os juizados especiais criminais poderiam ser pensados como espaços de empoderamento das mulheres. ${ }^{100}$ Compreendo que em alguns casos, quando as mulheres relatam que suas expectativas e demandas foram atendidas, a decisão de arquivar o processo também pode ser pensada como uma decisão que vai de encontro às expectativas iniciais dessas mulheres e como uma maneira delas se apropriarem da legislação.

\section{5 - Percepções sobre a efetividade das medidas protetivas de urgência}

Por fim, não poderia encerrar este capítulo sem uma nota sobre as percepções das minhas interlocutoras acerca das medidas protetivas de urgência (MPU) ${ }^{101}$. É interessante que mesmo as mulheres cujos agressores se afastaram após elas terem conseguido o deferimento dessas medidas protetivas apresentam desconfiança e/ou descrédito em relação a esse procedimento.

O questionamento aqui não está relacionado ao tempo em que a medida protetiva de urgência demora a ser concedida. A única percepção neste sentido foi a relatada por Ana Clara, sobre o atendimento que recebeu na delegacia e o fato de a medida protetiva ter demora a ser concedida porque o inquérito não havia prosseguido. Ana Clara também foi a única interlocutora que considera que a medida protetiva contribuiu para que ela se sentisse mais segura porque naquele momento "eu vi que a lei era realmente eficaz e que o que estava escrito na lei estava se cumprindo para mim”.

A questão é que mesmo as mulheres que se sentiram atendidas pela LMP, que consideram que suas demandas foram atendidas pela justiça, não acham que somente a medida protetiva irá protegê-las. Marina, que teceu elogios a maneira como foi atendida pelo sistema de justiça diz:

\footnotetext{
Marina: - Não funciona. E isso é fato. Não existe isso, medida protetiva! Até parece que ele ia ficar 300 metros distante de mim. Se ele quisesse me matar ele já tinha me assassinado! Krislane: - Então você acha que se ele quisesse te matar, com ou sem medida protetiva... Marina: -Com ou sem medida protetiva ele já tinha! Porque medida protetiva é ilusão, gente! Por um acaso o policial vai ficar rondando aqui? o que é medida protetiva? é só um papel falando que você tem que ficar $300 \mathrm{~m}$ de distância, que se não ficar, vai responder a isso, isso e aquilo. Mas e antes? Se você
}

\footnotetext{
${ }^{100}$ Importante observar que o texto foi escrito em 2004, antes da promulgação da LMP.

101 A Lei 11.340/2006 prevê em seu texto a aplicação de medidas protetivas de urgência. As medidas protetivas de urgência são providências garantidas por lei às vítimas de violência doméstica e familiar, cuja finalidade é garantir a proteção dessas pessoas. Fonte: http://www.tjdft.jus.br/institucional/imprensa/direito-facil/dasmedidas-protetivas-de-urgencia.Último acesso em 19 de maio de 2015. Para mais informações, consultar o Art. 18, Art. 19, Art. 22 e Art. 23 da Lei 11.340/2006 disponíveis no Anexo I deste trabalho.
} 
vai lá e assassina a pessoa? Você vai fazer o quê? Você vai responder! Então isso aí é falho! É só papel mesmo!

Já Rachel lembra que o ex-marido sentiu medo de ser preso e que ela utilizava este temor quando ele ligava ou enviava mensagens para ela, lembrando-o do processo. Contudo ela conta que "ele não estava nem aí com essa distancia de duzentos metros" e continuava, por exemplo, frequentado a vizinhança e a rua em que ela morava. O argumento apresentado por Conceição vai nessa mesma direção. Encerro o capítulo com sua fala:

É uma coisa falha... eu sei que eles não tem muito o que fazer, mas não tem essa garantia. Aquela medida protetiva ela... Ele sabe que não pode avançar $300 \mathrm{~m}$, essas coisas, mas nada vai impedir. Igual eu falei para eles "vocês não vão colocar um policial no meu portão? Todas as mulheres vocês vão colocar um policial? Vão colocar um guarda-costas? Então é uma coisa assim, que tá ali no papel. Agora ele sabe que tem uma proteção assim, escrita. Que se ele mexer, ele vai ter consequências. Mas que você não tem essa proteção. Você tem aquela proteção no papel, que se fizer, vai ser punido. Mas quem é que vai impedir de fazer? (...) No tempo em que eu descia da parada para minha casa até o policial chegar, ele fazia o que queria. Quem quer fazer de verdade, chega, arromba um portão, faz o que quer. Então assim, é uma proteção... Claro que é bom, que a lei intimida, que não é como antes, que ficava por isso mesmo, que era como matar um gato. Mas para quem quer chegar e cometer o crime e quer fazer, não tem nada que impeça. 


\section{CONSIDERAÇÕES FINAIS}

Nesta dissertação estive interessada em compreender as percepções de mulheres que passaram por situações de violência doméstica e familiar. As mulheres em questão foram atendidas no Juizado de Violência Doméstica e Familiar contra a Mulher do Núcleo Bandeirante, Distrito Federal. Este juizado desenvolveu vários projetos modelos de atuação judicial, dentre os quais se destaca o Centro Judiciário da Mulher, cujo objetivo é estabelecer um modelo de atuação judicial baseado na Lei 11.340/2006. Meu intuito era acessar as percepções das mulheres atendidas nesse local acerca das experiências que elas tiveram ao acionar a Lei Maria da Penha através do sistema de justiça criminal.

Nas últimas décadas aconteceram significativas mudanças no modo como a sociedade brasileira passou a analisar os crimes envolvendo situações de violência doméstica e familiar contra mulheres. Em estudo produzido na década de 1970, Corrêa (1983:308) chama atenção para o fato de que sofriam "maiores condenações os apresentados como inadequados ao modelo de comportamento social implícito nos códigos e explicitado na sua aplicação”. Havia uma desigualdade de tratamento que qualificava alguns atos de transgressão como legítimos e, portanto, aceitos (p. 297). Dessa maneira, o julgamento dos casos era baseado em estereótipos do que seria o comportamento socialmente aceito e considerado adequado para homens e mulheres:

\footnotetext{
Um homem deve trabalhar para o sustento da sua família e uma mulher deve manter-se fiel a esse homem e se isso não ocorre, sempre é melhor não se investigar porquê. A resposta poderia pôr em risco, fazer entrar em crise, as bases sobre as quais se assentam não só os códigos legais como as normas mais amplas de relacionamento social (CORRÊA, 1983:310).
}

Neste contexto, era de certa forma "legítimo" e aceitável controlar as mulheres através da violência, especialmente as mulheres que não desempenhavam o que previa o estereótipo socialmente aceito sobre o comportamento feminino. Contudo, ao longo das últimas décadas ocorreram mudanças sociais e políticas que alteraram o modo como o sistema de justiça criminal lida com estes conflitos. Uma das mudanças mais significativas sobre este tema no contexto brasileiro foi certamente a promulgação da Lei Maria da Penha, em 2006. Assim como Cortizo e Goyeneche (2010:104), compreendo que: 
avanço no que tange ao reconhecimento legal da igualdade através de um tratamento específico em relação aos diferentes segmentos e situações sociais.

Antes da Lei Maria da Penha, não havia legislação específica para atender as mulheres em situação de violência doméstica e familiar que procuravam o auxílio do Estado. Inovadora em muitos aspectos, a LMP foi de grande importância política no processo de colocar em evidência uma agenda que visibilizou a violência doméstica e familiar contra mulheres e fez o tema ser debatido em um lugar de destaque na sociedade.

O Distrito Federal entra nesse debate como um contexto altamente diferenciado em relação ao restante do país. Aqui estão concentrados cerca de $20 \%$ dos juizados especializados em atender este tipo de demandas. O Juizado de Violência Doméstica e Familiar contra a Mulher localizado no Núcleo Bandeirante vem desenvolvendo novas formas de lidar com demandas que por muito tempo foram reprimidas pelo judiciário. Como dito anteriormente, este juizado foi o primeiro do DF a contar com equipe de atendimento multidisciplinar e, atualmente, possui espaço em que está localizada a sede do Centro Judiciário da Mulher.

A Lei Maria da Penha representa um ganho político para as mulheres. Com a legislação, institucionalizou-se a leitura de conflitos antes considerados como pertencentes ao âmbito privado, através de uma perspectiva jurídica. Nesse contexto, tem acontecido um amplo e complexo processo, chamado de judicialização das relações sociais, que implicaria "um duplo movimento, pois ele amplia o acesso ao sistema judiciário e ao mesmo tempo desvaloriza outras formas de resolução do conflito, reforçando ainda mais a centralidade do Judiciário" (RIFIOTIS, 2007:237).

Todavia, judicializar conflitos não significa que as demandas trazidas pelas pessoas serão atendidas pelo sistema de justiça. Na tentativa de compreender "os atos ou eventos de desrespeito à cidadania que não são captados adequadamente pelo Judiciário ou pela linguagem dos direitos, no sentido estrito do termo" (2008:137), Cardoso de Oliveira utiliza o conceito de insulto moral. Compreendo que este conceito é particularmente interessante para compreender percepções, opiniões, trajetórias e experiências de mulheres sobre a judicialização dos seus casos.

Neste trabalho busquei tais percepções por meio das narrativas de mulheres que passaram pelo "projeto modelo" em vigor no Núcleo Bandeirante. Nesta busca, algumas questões me orientavam. Quais as percepções que elas possuem sobre a Lei Maria da Penha após terem acessado esta legislação? Essas mulheres se sentiram atendidas pelo sistema de justiça criminal? Se passassem por situação semelhante, acionariam novamente a legislação? 
Ao contrário do que imaginava, a diversidade de percepções sobre o acesso ao sistema de justiça e sobre a LMP caracterizou este trabalho. Não existe uma opinião única sobre todo este processo. As percepções das mulheres são baseadas nas expectativas que elas possuíam ao acionar a legislação e na forma como elas foram atendidas pelo sistema de justiça. Porém, os atendimentos oferecidos pelo sistema de justiça quando as mulheres acessam a Lei Maria da Penha são extremamente diversos.

Os atendimentos que minhas anfitriãs receberam dos diferentes operadores e agentes que compõe o sistema de justiça não é baseado apenas no que está escrito na legislação. As subjetividades relacionadas à forma como essas pessoas veem o mundo e interpretam a violência de gênero está claramente presente no atendimento que é oferecido a estas mulheres. A questão aqui é que não é incomum que no momento do atendimento estes agentes e operadores coloquem suas subjetividades e crenças pessoas acima do que está descrito na Lei Maria da Penha.

Ao longo da pesquisa, percebi que algumas mulheres esperavam que todas as suas demandas fossem atendidas através da Lei Maria da Penha. No entanto, esta legislação não consegue acolher a variedade desses pleitos. Nestes casos, percebi que quando as mulheres possuíam grandes expectativas, como por exemplo, que o agressor em questão ficasse preso ou que a LMP a ajudasse a solucionar demandas relacionadas a divórcios/separações litigiosas, era maior a possibilidade de elas se frustrarem em relação ao atendimento recebido.

O presente trabalho expõe a existência de vasta diversidade de experiências e percepções das mulheres em relação ao atendimento que elas acessaram quando acionaram à Lei Maria da Penha através do sistema de justiça criminal. Esta é uma questão que precisa ser explorada. Há uma lacuna de estudos sobre a opinião e as percepções das mulheres que acionaram a Lei 11.340/2006. É necessário explorar este espaço e pesquisar sobre/com essas mulheres.

É importante destacar que o contexto do Distrito Federal está em constante mudança. Notícia veiculada no site do TJDFT em 19/02/2015 informa sobre a portaria que regulamenta a utilização de medidas protetivas de urgência por meio eletrônico e em 01/06/2015 notícia veiculada no site do jornal "Correio Braziliense” informa sobre a inauguração, em Brasília, da segunda Casa da Mulher Brasileira no país. A Casa da Mulher Brasileira é um local que oferece acesso a vários serviços especializados à mulheres em situação de violência. ${ }^{102103}$

\footnotetext{
102 http://www.tjdft.jus.br/institucional/imprensa/noticias/2015/fe

vereiro/tjdft-regulamenta-utilizacao-de-medida-protetiva-por-meio-eletronico
} 
Estas notícias ajudam pensar sobre o contexto local de atendimento às mulheres em situação de violência doméstica e como as redes e serviços no Distrito Federal voltadas a este público estão em constante alteração. Nos últimos cinco anos, houve grande transformação neste tipo de atendimento especializado, o que torna a região um lócus de pesquisa que merece atenção.

É importante fazer pesquisas no sistema de justiça criminal e em suas instituições, principalmente no que se referem a estes novos atendimentos. Porém, é necessário acessar as usuárias deste sistema. É fundamental ampliar as relações com essas mulheres, conhecer os contextos sociais em que elas vivem e a importância das dimensões relacionais na qual elas estão inseridas. É necessário estabelecer redes de contato, cruzar dados de idade, renda, classe, características étnico-raciais, localização geográfica e etc., na tentativa de conhecer quem são essas mulheres e quais são suas demandas. Este é um campo que oferece muitas possibilidades e são várias as questões que podem ser exploradas.

Mas para isso, é necessário superar as dificuldades metodológicas de acesso a essas mulheres. Houve imensa dificuldade em contatar minhas anfitriãs, que se mostraram extremamente receosas ao serem abordadas para conversar sobre este tema. É necessário aprimorar estratégias de aproximação com as mulheres e pensar em novas estratégias metodológicas que consigam acessar essas mulheres. Seria interessante, por exemplo, realizar estudo que acompanhasse todas as etapas do acesso dessas mulheres ao sistema de justiça. $\mathrm{Ou}$ construir etnografias a partir de estudos de caso sobre mulheres que acessaram este sistema.

Não se trata de estabelecer o que foi dito pelas minhas anfitriãs como uma verdade inquestionável. Entretanto, é fundamental acessar e compreender as concepções dessas mulheres sobre o atendimento que elas receberam quando acionam a Lei Maria da Penha. Também é preciso refletir sobre os casos em que a legislação não consegue atender as diferentes expectativas apresentadas pelas mulheres em situação de violência. É relevante que muitas vezes as mulheres não sabem que a Lei 11.340/2006 prevê outras formas de violência doméstica e familiar além da violência física. É preciso produzir dados que ajudem a pensar sobre esta problemática. Outro aspecto importante e que deve ser pesquisado é a percepção das mulheres sobre a efetividade das medidas protetivas de urgência.

Considero fundamental refletir e compreender as estratégias utilizadas por essas mulheres para se apropriarem da legislação. Com este trabalho, percebe-se que as mulheres

\footnotetext{
${ }^{103} \mathrm{http}: / /$ www.correiobraziliense.com.br/app/noticia/cidades/2015/06/01/interna_cidadesdf,485205/casa-damulher-brasileira-e-inaugurada-nesta-segunda-em-brasilia.shtml
} 
também utilizam a legislação para renegociar os termos e condições nas suas relações afetivas, como recurso de poder dentro dos relacionamentos.

Definitivamente este estudo não aponta conclusões sobre o tema. Não foi minha intenção nessa pesquisa exaurir ou dar respostas para essas questões. Ao contrário, a pesquisa abriu um leque de questões que, espero, possam servir de orientação para trabalhos futuros e contribua para refletir sobre o acesso ao sistema de justiça e aplicação da Lei Maria da Penha. 


\section{REFERÊNCIAS BIBLIOGRÁFICAS}

AMORIM, M. Stella. "Acesso à justiça e administração judicial da violência contra a mulher brasileira: políticas de despenalização e de penalização". Anais do XIII Congresso da Anpedi. 2008. Disponível em: <http://conpedi.org/manaus////arquivos/anais/campos/maria_stella_de_amorim.pdf > .

ANDRADE, Fabiana de. Fios para Trançar, Jogos para Armar: O Fazer Policial nos Crimes de Violência Doméstica e Familiar Contra a Mulher. 2012.

AZEVEDO, Rodrigo Ghiringhelli de.; VASCONCELLOS, Fernanda Bestetti de. A Lei Maria da Penha e a administração judicial de conflitos de gênero: Inovação ou reforço do modelo penal tradicional?. Dilemas, v. 5, p. 549-568, 2012.

AZEVEDO, Rodrigo Ghiringhelli de ; VASCONCELLOS, Fernanda Bestetti de. Novos Discursos, Novas Práticas? Uma Análise das Inovações no Campo do Controle do Crime no Brasil. In: $28^{a}$ Reunião Brasileira de Antropologia, 2012, São Paulo - SP. Anais da $28^{\text {a }}$ Reunião Brasileira de Antropologia, 2012.

AZEVEDO, Rodrigo Ghiringhelli de. A força do direito e a violência das formas jurídicas. Revista de Sociologia e Política (UFPR. Impresso), v. 19, p. 27-41, 2012.

AZEVEDO, Rodrigo Ghiringhelli de ; VASCONCELLOS, Fernanda B. ; RIBEIRO, F. ; SIMIÃO, D. ; PASINATO, W. . O Atendimento de Crianças, Adolescentes e Mulheres Vítimas de Violência pelas Instituições de Segurança Pública do Distrito Federal e das Cidades de Porto Alegre e Belo Horizonte. 2014. (Relatório de pesquisa).

AZEVEDO, Rodrigo Ghiringhelli de. Juizados Especiais Criminais: Uma abordagem sociológica sobre a informalização da Justiça Penal no Brasil. Civitas (Porto Alegre), Porto Alegre, v. 1, n.2, p.113-124, 2001.

AZEVEDO, Rodrigo Ghiringhelli de Sistema Penal e Violência de Gênero: Análise SócioJurídica da Lei 11.340/06. Sociedade e Estado, v.23, p. 113-135, 2008.

AZEVEDO, Maria Paula Marins Sarmento de. O Universo dos Conflitos Domésticos e da Lei Maria da Penha: Questões de Direito e Dignidade. 2011. Trabalho de Conclusão de Curso. (Graduação em Ciências Sociais) - Departamento de Antropologia, Universidade de Brasília. Brasília, 2012.

BANDEIRA, Lourdes Maria. Três décadas de resistência feminista contra o sexismo e a violência feminina no Brasil: 1976 a 2006. Revista Sociedade e Estado, Brasília, p.401-438, 2009.

BANDEIRA, Lourdes Maria; ALMEIDA, Tânia Mara Campos de. Vinte anos da Convenção de Belém do Pará e a Lei Maria da Penha. Revista Estudos Feministas, Florianópolis, v. 23, n. 2, p. 501- 517, 2015.

BERALDO DE OLIVEIRA, Marcella, DEBERT, Guita Grin. Os modelos conciliatórios de solução de conflitos e a violência doméstica. Cadernos Pagu (UNICAMP), v. 29, p. 305337, 2007. 
BERALDO DE OLIVEIRA. Marcella. CRIME INVISÍVEL: mudança de significados da violência de gênero no Juizado Especial Criminal. Mestrado em Ciências Sociais Universidade de Estadual de Campinas, Campinas, 2006.

BERGER, Peter. On the Obsolescence of the Concept of Honor. In Hauerwas, S., MACINTYRE, A. (eds), Revisions: Changing Perspectives in Moral Philosophy, Notre Dame (Indiana), Notre Dame University Press, p. 172-81, 1983.

BORGES, Antonádia. Mulheres e suas casas: reflexões etnográficas a partir do Brasil e da África do Sul. Cad. Pagu, Campinas, n. 40, June 2013.

BRASIL. Constituição da República Federativa do Brasil de 1988. Disponível em: www.planalto.gov.br/ccivil_03/constituicao/constituicaocompilado.htm. Acesso em: 12 de maio de 2015.

Lei $\mathbf{n}^{\circ}$ 11.340, de 07 de agosto de 2006. Data da publicação 22 de agosto de 2006. Cria Mecanismos para coibir a violência doméstica e familiar contra a mulher. Disponível em: http://www.planalto.gov.br/ccivil_03/_ato2004-2006/2006/lei/111340.htm. Acessado em: 21 de abril de 2012

Presidência da República. Lei 9.099/95 de 26 de setembro de 1995. Dispõe sobre os Juizados Especiais Cíveis e Criminais e dá outras providências. Disponível em: /www.planalto.gov.br/ccivil_03/leis/19099.htm. Acesso em: 14 maio 2015.

Presidência da República. Lei $\mathbf{n}^{\mathbf{0}} \mathbf{1 1 . 3 4 0}$, de 7 de agosto de 2006. Cria mecanismos para coibir a violência doméstica e familiar contra a mulher. Disponível em: http://www.planalto.gov.br/ccivil_03/_ato2004-2006/2006/lei/111340.htm. Acesso em: 20 julho de 2015.

. Senado Federal. Comissão Parlamentar Mista de Inquérito da Violência contra a

Mulher. Relatório Final. Brasília, 2013. Disponível em: http://www.senado.gov.br/atividade/materia/getPDF.asp?t=130748\&tp=1. Acesso em: $18 \mathrm{de}$ julho de 2015

BRECHT, Bertolt. O Pão do Povo. In: Poemas (1913-1956), São Paulo, Brasiliense, 1986.

CAMPOS, Carmen Hein; CARVALHO, Salo de. Tensões atuais entre a criminologia feminista e a criminologia crítica: a experiência brasileira. In: CAMPOS, Carmen Hein de. (Org.). Lei Maria da Penha Comentada em uma Perspectiva Jurídico-Feminista. Rio de Janeiro: Lumen Juris, p. 143-169, 2011.

CARDOZO, Gleidismara dos Santos. Uma Gaiola de Ouro: Violência Conjugal Contra Mulheres das Camadas Médias de Florianópolis ' 01/04/2012 188 f. DOUTORADO em ESTUDOS INTERDISCIPLINARES SOBRE MULHERES, GÊNERO E FEMINISM Instituição de Ensino: UNIVERSIDADE FEDERAL DA BAHIA Biblioteca Depositária: BIBLIOTECA ISAÍAS ALVES.

CARDOSO OLIVEIRA, Luís Roberto Cardoso de. Existe violência sem agressão moral? Revista Brasileira de Ciências Sociais, São Paulo, v. 23, n.67, p.135-146, 2008.

CARDOSO OLIVEIRA, Luís Roberto Cardoso de. Honra, dignidade e reciprocidade. Série Antropologia. PPGAS/UNB, Brasília, 2004. 
CARDOSO OLIVEIRA, Luís Roberto Cardoso de. Existe Violência Sem Agressão Moral? In Revista Brasileira de Ciências Sociais (Impresso), 2008. v. 23, p. 135-146.

CARDOSO OLIVEIRA, Luís Roberto Cardoso de. A dimensão simbólica dos direitos e a análise de conflitos. Revista de Antropologia (USP. Impresso), 2011. v. 53, p. 451-473.

CARDOSO OLIVEIRA, Luís Roberto Cardoso de. Entre O Justo e O Solidário: Os Dilemas dos Direitos de Cidadania no Brasil e nos EUA. REVISTA BRASILEIRA DE CIÊNCIAS SOCIAIS, v. 11, n.31, p. 67-81, 1996.

CARNEIRO, Valneda Cassia Santos. O Combate Institucional da Violência Contra a Mulher: Estudo Comparativo entre Brasil, Portugal e Espanha na implantação de politicas públicas. 2012.

CASTRO, Nicholas Moreira Borges. Agentes estatais e o trabalho em rede: Uma experiência institucional de atenção aos conflitos abarcados pela Lei Maria da Penha. Trabalho de Conclusão de Curso. (Graduação em Ciências Sociais) - Universidade de Brasília, Brasília, 2013.

CONVENÇÃO INTERAMERICANA para prevenir, punir e erradicar a violência contra a mulher. Convenção de Belém do Pará, 1994. Disponível em: http://www.pge.sp.gov.br/centrodeestudos/bibliotecavirtual/instrumentos/belem.htm. Acesso em maio de 2015.

CORREA, Ranna Mirthes Sousa. Lei Maria da Penha e a Judiciarização da violência doméstica contra a mulher nos Juizados do Distrito Federal: um estudo de caso na Estrutural. Trabalho de Conclusão de Curso. (Graduação em Ciências Sociais) Universidade de Brasília, Brasília, 2012.

CORRÊA, Mariza. Morte em Família. Rio de Janeiro: Graal, 1983.

CORTIZO, María del Carmen; GOYENECHE, Priscila Larratea. Judiciarização do privado e violência contra a mulher. Rev. katálysis, Florianópolis , v. 13, n. 1, p. 102-109, 2010 .

COSTA, Renata Cristina de Faria Gonçalves. Atos e Autos: Uma etnografia Sobre Violência Doméstica e o sistema de Justiça. Trabalho de Conclusão de Curso. (Graduação em Direito) Universidade de Brasília, Brasília, 2013.

DEBERT, Guita; PORTO, Rozeli.; MOTTA, Flávia de Mattos. Guita Debert. In: Miriam Pillar Grossi; Luzinete Simões Minella; Rozeli Porto. (Org.). Depoimentos: trinta anos de pesquisas feministas brasileiras sobre violência. Editora Mulheres, Florianópolis, v.1, p. 169$212,2006$.

DEBERT, Guita Grin; GREGORI, Maria Filomena. Violência e gênero: novas propostas, velhos dilemas. Revista Brasileira de Ciências Sociais, n.66: p.166-185, 2008.

DIAS, Maria Berenice. Aspectos Civis e Processuais Civis Da Lei No 11.340/06. Acessado em 21 de abril de 2012. Disponível em: http://www.mariaberenice .com.br/uploads/18__aspectos_civis_e_processuais_civis_da_lei_11.340-06.pdf 
DO CARMO, Milena Cunha dos Santos. Eu Ser um Homem Feminino Não Fere meu Lado Masculino: Percepções e Socializações nos Grupos Reflexivos de Gênero para Homens 2012.

ETAYO, Elizabeth Gomez. Nem Anjos, nem Demônios: Homens Comuns. Narrativas sobre masculinidades e violência de gênero. ' 01/02/2011 210 f. DOUTORADO em CIÊNCIAS SOCIAIS Instituição de Ensino: UNIVERSIDADE ESTADUAL DE CAMPINAS Biblioteca Depositária: BIBLIOTECA OCTÁVIO IANNI/IFCH E BIBLIOTECA CENTRAL/UNICAMP

FACHINETTO, Rochele Fellini. Quando Eles As Matam E Quando Elas Os Matam: Uma Análise Dos Julgamentos De Homicídio Pelo Tribunal Do Júri ' 01/05/2012 421 f. DOUTORADO em SOCIOLOGIA Instituição de Ensino: UNIVERSIDADE FEDERAL DO RIO GRANDE DO SUL Biblioteca Depositária: BSCSH/UFRGS.

FEIX, Virginia. Das formas de violência contra a mulher - art. $\mathbf{7}^{\mathbf{0}}$. In: CAMPOS, Carmen Hein de (Org.). Lei Maria da Penha comentada em uma perspectiva jurídico-feminista. Rio de Janeiro: Lumen Juris, p. 201-213, 2011.

FERREIRA, Helder; FONTOURA, Natália de Oliveira. Sistema de justiça criminal no Brasil: quadro institucional e um diagnóstico de sua atuação. Brasília: Ipea, março de 2008.

FONSECA, C. Quando Cada Caso não é Um Caso: Pesquisa Etnográfica e Educação. Revista Brasileira de Educação, n. 10, p. 58-78, 1999.

FONSECA, Claudia. As novas tecnologias legais na produção da vida familiar. Antropologia, direito e subjetividades. Civitas n. 11, v.1, p 8-23, 2011.

GEERTZ, Clifford. O Saber Local: fatos e leis em uma perspectiva comparativa. In: O Saber Local: Novos ensaios em Antropologia interpretativa. Petrópoles: Vozes, 1998.

GEERTZ, Clifford. A Interpretação das Culturas. Rio de Janeiro: Ed. Guanabara Koogan, 1989.

GOMES, Izabel Solyszko. Campo Minado: Um estudo sobre femicídios na região metropolitana de Cuiabá. 2010. Seminário Internacional Fazendo Gênero 10, Anais Eletrônicos, Florianópolis, 2013.

GREGORI. Maria Filomena. Cenas e queixas: um estudo sobre as mulheres, relações violentas e a prática feminista. São Paulo: Paz e Terra/ANPOCS, 1993. V. 1. 215p.

GREGORI, Maria Filomena; PORTO, Rozeli; TEIXEIRA, Analba Brazão Maria Filomena Gregori. Depoimentos: trinta anos de pesquisas feministas brasileiras sobre violência. In: Miriam Pillar Grossi; Luzinete Simões Minella; Rozeli Porto. (Org.). 1ed.Florianópolis: Editora Mulheres, v. 1, p. 257-273, 2006.

GROSSI, Miriam Pillar. "Na busca do 'outro' encontra-se a si mesmo". In (Org.).Trabalho de campo e subjetividade. PPGAS/UFSC, Florianópolis, p. 7-18, 1992.

KANT DE LIMA, Roberto. Da Inquirição ao Júri, do Trial by Jury à Plea Bargaining: Modelos para a Produção da Verdade e a Negociação da Culpa em uma Perspectiva 
Comparada Brasil/Estados Unidos. Tese ao Concurso de Professor Titular em Antropologia do Departamento de Antropologia da Universidade Federal Fluminense, Niterói, p. 72, 1995.

KANT DE LIMA, Roberto. Por uma Antropologia do Direito, no Brasil. In: Ensaios de antropologia e direito. Rio de Janeiro: Lúmen Júris, 2008. 74

KANT DE LIMA, Roberto. Administração de conflitos, espaço público e cidadania-uma perspectiva comparada. In: Civitas: Revista de Ciências Sociais, Porto Alegre/RS, v. 1, n.2, p. 11-16, 2001.

KANT DE LIMA, Roberto. Sensibilidades jurídicas, saber e poder: bases culturais de alguns aspectos do direito brasileiro em uma perspectiva comparada. In: Anuário Antropológico, Brasília, v. 2, p. 25-51, 2010.

LISBOA, Teresa Kleba. Violência de gênero ou feminicídio? Leis sobre violência e propostas de políticas públicas no Brasil e no México. In: RIAL,Carmen; PEDRO, Joana Maria; AREND, Silvia M. Fávero.. (Org.). Diversidades: dimensões de gênero e sexualidade. 1 ed.Florianópolis: Editora Mulheres, 2010, v. 01, p. 61-80.

MACHADO, Lia Zanotta; MAGALHÃES, Maria Teresa Bossi de. Violência conjugal: os espelhos e as marcas. Série Antropologia. PPGAS/UNB, Brasília, 1998.

MACHADO, Lia Zanotta. Atender vítimas e criminalizar violências: dilemas das delegacias de mulheres. Brasília: Departamento de Antropologia da UnB, 2002. (Série Antropolia; n.319)

MACHADO, Lia Zanotta e MAGALHÃES, Maria Teresa Bossi de Magalhães. Violência Conjugal: os Espelhos e as Marcas. In: SUÁREZ, M. e BANDEIRA, L. M. (eds.) Violência, Gênero e Crime no Distrito Federal. Brasília, EDUnB/Ed. Paralelo 15, 1999.

MACHADO, Isadora Vier; GROSSI, Miriam Pillar. Da dor no corpo à dor na alma: o conceito de violências psicológicas da Lei Maria da Penha. Revista Estudos. Feministas, Florianópolis , v. 23, n. 2, p. 561-576, 2015.

MAUSS, Marcel. 1974 [1923-24]. Ensaio sobre a dádiva. Forma e razão da troca nas sociedades arcaicas. In : Sociologia e Antropologia. v. II. São Paulo : Edusp

MATIAS, Krislane de Andrade. Um novo tratamento judicial para a Lei Maria da Penha? Uma etnografia da equipe multidisciplinar do Fórum do Núcleo Bandeirante. Trabalho de Conclusão de Curso. (Graduação em Ciências Sociais) - Universidade de Brasília, Brasília, 2013.

MENDES, Regina Lúcia Teixeira. "Verdade real e livre convencimento: $O$ processo decisório judicial brasileiro visto de uma perspectiva empírica". DILEMAS: Revista de Estudos de Conflito e Controle Social - Vol. 5 - no 3 - JUL/AGO/SET 2012 - pp. 447-482.

MOURA, Gustavo Augusto Gomes de. L. Sai à Procura de Justiça: Etnografando as Experiências de uma Mulher em seu Encontro com o Estado. ' 01/03/2011 158 f. MESTRADO ACADÊMICO em ANTROPOLOGIA Instituição de Ensino: UNIVERSIDADE DE BRASÍLIA Biblioteca Depositária: BIBLIOTECA CENTRAL DA UNB. 
NUNES, Maria Terezinha. Cercas que se Levantam: Análise das Decisões do Superior Tribunal de Justiça em Quatro Anos de Aplicação da Lei Maria da Penha. 2011.

OLIVEIRA, Anderson Eduardo Carvalho de. A Experiência Estatal Brasileira no Atendimento a Homens Autores de Violência Doméstica e Familiar Contra a Mulher. 2012.

OLIVEIRA, Carlos Gomes de. Na Maior Brevidade Possível - Tensões na Administração da Justiça em uma Vara Criminal do DF ' 01/11/2012 300 f. DOUTORADO em SOCIOLOGIA Instituição de Ensino: UNIVERSIDADE DE BRASÍLIA Biblioteca Depositária: BIBLIOTECA CENTRAL DA UNIVERSIDADE DE BRASÍLIA - BCE - UNB

OLIVEIRA, Carlos Gomes de. Saber Calar, Saber Conduzir a Oração: A Administração de Conflitos num Juizado Especial Criminal do DF. 2005. 148 páginas. Mestrado em Antropologia - Universidade de Brasília, Brasília, 2005

OLIVEIRA, Roberto Cardoso de. O trabalho do antropólogo: olhar, ouvir, escrever. In: O trabalho do antropólogo. $2^{\mathrm{a}}$ ed. Brasília: Paralelo 15; São Paulo: UNESP, 2000. p. 17-35

ORTNER, Sherry. Introduction. In: The fate of "culture": Geertz and Beyond, Los Angeles, University of California Press, p. 1 -14, 1999.

ORTNER, Sherry. Geertz, subjetividad y conciencia posmoderna. In:Etnografias Contemporâneas, Escuela de Elumanmdades, Unsam, Buenos Aires, ano 1, p.25-53, 2005.

PASINATO, Wânia. Delegacias de Defesa da Mulher e Juizados Especiais Criminais: mulheres, violência e acesso à justiça. XXVIII Encontro da Associação Nacional de Pós Graduação em Ciências Sociais -ANPOCS. Anais. Caxambu, 2004.

PASINATO, Wânia. Contribuições para o Debate sobre Violência, Gênero e Impunidade no Brasil. São Paulo em Perspectiva, v. 21 (2), p. 5-14, 2007.

PASINATO, Wânia. Lei Maria da Penha: novas abordagens sobre velhas propostas. Onde avançamos?. In: Civitas: Revista de Ciências Sociais, v. 10, p. 216-232, 2010.

PASINATO, Wânia. "Femicídios" e as mortes de mulheres no Brasil. In: Cadernos Pagu, Campinas, n. 37, p. 219-246, 2011.

PASINATO, Wânia. Oito anos de Lei Maria da Penha: Entre avanços, obstáculos e desafios. In: Revista Estudos Feministas, Florianópolis , v. 23, n. 2, p. 533-545, 2015.

PASINATO, Wânia. Violência, Gênero e Acesso à Justiça. Contribuições da Delegacia Especial de Crimes Contra a Mulher e da Rede de Enfrentamento a Violência de Minas Gerais. 2009. (Relatório de pesquisa).

PASINATO, Wânia e SANTOS, Cecília MacDowell dos. Violência contra as mulheres e violência de gênero. Notas sobre Estudos Feministas no Brasil. In: Revista Estudios Interdisciplinários de America Latina y El Caribe. Israel: Universidade de Tel Aviv, VOL.16 $-\mathrm{N}^{\mathrm{o}}$ 1, 2005, PAG.147-164.

PEIRANO, Mariza. Lembranças. Mana, Rio de Janeiro, v. 14, n. 2, p. 563-570, 2008. 
PEIRANO, Mariza. Posfácio. In: A favor da etnografia. Rio de Janeiro, Relume-Dumará, 1995.

PEIRANO, Mariza. A Favor da Etnografia - Série Antropologia 130 - Universidade de Brasília. 1992. Instituto de Ciências Humanas, Departamento de Antropologia.

PINTO, Céli Regina Jardim. O feminismo bem-comportado de Heleieth Saffioti (presença do marxismo). In: Estudos Feministas v.22, n.1 p. 321-333, 2014.

PISCITELLI, A. G. Delegacias Especiais de Polícia em contexto: reflexões a partir do caso de Salvador - BA. In: Debert, Guita; Gregori Maria Filomena; Piscitelli Adriana. (Org.). Gênero e distribuição da justiça: as delegacias de defesa da mulher e a construção das diferenças. Campinas: PAGU/UNICAMP, 2006, v. , p. 89-145.

RIFIOTIS, Theophilos. As delegacias especiais de proteção à mulher no Brasil e a judiciarização dos conflitos conjugais. Sociedade e Estado (UnB. Impresso), Brasília, v. 19, n.1, p. 85-119, 2004.

RIFIOTIS, Theophilos. Alice do outro lado do espelho: revisitando as matrizes das violências e dos conflitos. Revista de Ciências Sociais (UFC), v. 37, p. 27-33, 2006.

RIFIOTIS, Theophilos. Direitos Humanos: Sujeitos de direitos e direitos dos sujeitos. In: Rosa Mair Godoy Silveira; Adelaide Alves Dias; Lúcia de Fátima Guerra Ferreira; Maria Luíza 76 Pereira de Alencar Mayer Feitosa; Maria de Nazaré Tavares Zenaide. (Org.). Educação em Direitos Humanos: Fundamentos teórico-metodológicos. João Pessoa: Editora Universitária, 2007, v. , p. 231-244.

RIFIOTIS, Theophilos. Judiciarização das relações sociais e estratégias de reconhecimento: repensando a 'violência conjugal' e a ' violência intrafamiliar'. Revista Katál Florianópolis. v.11. n. 2. Pg. 225-236. UFSC. 2008.

RIFIOTIS, Theophilos. Violência conjugal e acesso à justiça: um olhar crítico sobre a judiciarização das relações sociais. In: Antonio Carlos de Souza Lima. (Org.). Antropologia \& Direito. Temas antropológicos para estudos jurídicos. Rio de Janeiro; Brasília: Contra Capa/LACED/Associação Brasileira de Antropologia, 2012, v. , p. 300-308.

RIFIOTIS, Theophilos; SCHRITZMEYER, Ana Lúcia Pastore. Jogo, Ritual e Teatro: um estudo antropológico do tribunal do júri. In: Ilha Revista de Antropologia v.16.n.1 p.234$250,2014$.

RIFIOTIS, Theophilos. As delegacias especiais de proteção à mulher no Brasil e a judicialização dos conflitos conjugais. In: Theophilos Rifiotis; Danielli Vieira. (Org.). Um olhar antropológico sobre violência e justiça: etnografias, ensaios e estudos de narrativas. 1ed. Florianópolis: Editora da UFSC, v. 1, p. 27-56, 2012.

SAFFIOTI, Heleieth Iara Bongiovani. Contribuições feministas para o estudo da violência de gênero. In: Cadernos Pagu. n.16, p. 115-136, 2001.

SAFFIOTI, Heleieth Iara Bongiovani. Violência de Gênero no Brasil Atual. In: Revista Estudos Feministas, Rio de Janeiro, CIEC/ECO/UFRJ, nº especial, p.443-461, 1994. 
SANTOS, Luna Borges Pereira. Estratégias de enfrentamento à violência doméstica contra mulheres: um olhar etnográfico e feminista sobre a implementação da Lei Maria da Penha no Distrito Federal. Trabalho de Conclusão de Curso. (Graduação em Direito) Universidade de Brasília, Brasília, 2013.

SANTOS, Cecília MacDowell; PASINATO, Wânia. Violência contra as Mulheres e Violência de Gênero: Notas sobre Estudos Feministas no Brasil. In: E.I.A.L.- Estudios Interdisciplinarios de América Latina y El Caribe, v.16, n.1, p.147-164. 2005

SANTOS, Cecília MacDowell. Da Delegacia da Mulher à Lei Maria da Penha: lutas feministas e políticas públicas sobre violência contra mulheres no Brasil. In: Oficina do Centro de Estudos Sociais, Coimbra, n. 301, 2008.

SCHUCH, Patrice. Antropologia do Direito: trajetória e desafios contemporâneos. BIB Revista Brasileira de Informação Bibliográfica, v. 67, p. 51-73, 2009.

SEGATO, Rita Laura. Que és un feminicídio: Notas para un debate emergente. Série Antropologia, PPGAS/UnB, 2006.

SEGATO, Rita Laura Território, soberania e crimes de segundo Estado: a escritura nos corpos das mulheres de Ciudad Juárez. In: Revista Estudos Feministas, Florianópolis, v. 13 , n. 2, p. 265-285, 2005.

SIMIÃO, D. S., DUARTE, V. B., CARVALHO, N. F. e GONDIN, P.D. "Sentidos de justiça e reconhecimento em formas extra-judiciais de resolução de conflitos em Belo Horizonte". In: KANT DE LIMA, Roberto; EILBAUM, Lucia; PIRES, Lenin (orgs.). Conflitos, Direitos e Moralidades em perspectiva comparada. Rio de Janeiro: Garamond, 2010.v.1.p.221-250.

SIMIÃO, DanieL. Representando corpo e violência: a invenção da 'violência doméstica' em Timor-Leste. Revista Brasileira de Ciências Sociais. São Paulo, v. 21, n.60, p. 133-145, 2006.

SIMIÃO, Daniel. As Donas da Palavra: gênero, justiça e a invenção da violência doméstica em Timor-Leste. Brasília: Editora UnB, 2015.

SIMIAO, Daniel; CARDOSO DE OLIVEIRA, Luís Roberto. Uma análise do tratamento judicial de casos de violência doméstica no Distrito Federal. Anais da IX Reunião de Antropologia do Mercosul - RAM. Curitiba, 2011.

SIMIÃO, Daniel. Sensibilidades Jurídicas e Respeito às Diferenças: cultura, controle e negociação de sentidos em páticas judiciais no Brasil e em Timor-Leste. Anuário Antropológico, v. 39, p. 237-260, 2014.

SIMIÃO, D. S., DUARTE, V. B., CARVALHO, N. F. e GONDIN, P.D. "Sentidos de justiça e reconhecimento em formas extra-judiciais de resolução de conflitos em Belo Horizonte". In: KANT DE LIMA, Roberto; EILBAUM, Lucia; PIRES, Lenin (orgs.). Conflitos, Direitos e Moralidades em perspectiva comparada. Rio de Janeiro: Garamond, 2010.v.1.p.221-250. 
SOUZA, Erika Giuliane Andrade. Feijoada: Administração de Conflitos nas Delegacias da Cidade do Rio de Janeiro. In: 26a Reunião Brasileira de Antropologia, realizada entre os dias 01 e 04 de junho, Porto Seguro, Bahia, 2007.

SOARES, Barbara Musumeci. A "conflitualidade conjugal" e o paradigma da violência contra a mulher. In: Dilemas, v. 5, n. 2, p.191-210, 2012.

SOARES, Barbara Musumeci. Enfrentando a Violência contra a Mulher - Orientações Práticas para Profissionais e Voluntários(as). Secretaria Especial de Políticas para as Mulheres, Brasília, 2005.

STARR, June; COLLIER, Jane F. (eds.). Introduction: dialogues in legal anthropology. In: History and power in the study of law: new directions in legal anthropology. Ithaca and London: Cornell Univ. Press, 1989.

TEIXEIRA MENDES, Regina Lucia. Verdade Real e Livre Convencimento: o processo decisório judicial brasileiro visto de uma perspectiva empírica. In:Dilemas: Revista de Estudos do Conflito e Controle Social Rio de Janeiro. v. 5, n.3, p. 447-482, 2012.

TEIXEIRA MENDES, Regina Lucia. Dilemas da decisão judicial. As representações dos juízes brasileiros sobre o principio do livre convencimento do juiz e outros princípios correlatos. In: Revista de Ciências Sociais. Rio de Janeiro, v. 14, n.1, p.191-207, 2008.

VAZ, Antonio Carlos. Violência Contra as Mulheres: Estudo com Adolescentes no Município de Guarulhos ' 01/12/2012 203 f. DOUTORADO em CIÊNCIAS SOCIIAIS Instituição de Ensino: UNIVERSIDADE EST.PAULISTA JÚLIO DE MESQUITA FILHO/ARARAQUARA Biblioteca Depositária: UNESP 
ANEXO I:

Lei 11.340 de 07 de agosto de 2006 - Lei Maria da Penha 
ANEXO: LEI 11.340 DE 07 DE AGOSTO DE 2006

\begin{abstract}
Cria mecanismos para coibir a violência doméstica e familiar contra a mulher, nos termos do $\S 8^{\circ}$ do art. 226 da Constituição Federal, da Convenção sobre a Eliminação de Todas as Formas de Discriminação contra as Mulheres e da Convenção Interamericana para Prevenir, Punir e Erradicar a Violência contra a Mulher; dispõe sobre a criação dos Juizados de Violência Doméstica e Familiar contra a Mulher; altera o Código de Processo Penal, o Código Penal e a Lei de Execução Penal; e dá outras providências.
\end{abstract}

O PRESIDENTE DA REPÚBLICA Faço saber que o Congresso Nacional decreta e eu sanciono a seguinte Lei:

\title{
TÍTULO I \\ DISPOSIÇÕES PRELIMINARES
}

Art. $1^{\circ}$ Esta Lei cria mecanismos para coibir e prevenir a violência doméstica e familiar contra a mulher, nos termos do $\S 8^{\circ}$ do art. 226 da Constituição Federal, da Convenção sobre a Eliminação de Todas as Formas de Violência contra a Mulher, da Convenção Interamericana para Prevenir, Punir e Erradicar a Violência contra a Mulher e de outros tratados internacionais ratificados pela República Federativa do Brasil; dispõe sobre a criação dos Juizados de Violência Doméstica e Familiar contra a Mulher; e estabelece medidas de assistência e proteção às mulheres em situação de violência doméstica e familiar.

Art. $2^{\circ}$ Toda mulher, independentemente de classe, raça, etnia, orientação sexual, renda, cultura, nível educacional, idade e religião, goza dos direitos fundamentais inerentes à pessoa humana, sendo-lhe asseguradas as oportunidades e facilidades para viver sem violência, preservar sua saúde física e mental e seu aperfeiçoamento moral, intelectual e social.

Art. $3^{\circ}$ Serão asseguradas às mulheres as condições para o exercício efetivo dos direitos à vida, à segurança, à saúde, à alimentação, à educação, à cultura, à moradia, ao acesso à justiça, ao esporte, ao lazer, ao trabalho, à cidadania, à liberdade, à dignidade, ao respeito e à convivência familiar e comunitária.

$\S 1^{\circ} \mathrm{O}$ poder público desenvolverá políticas que visem garantir os direitos humanos das mulheres no âmbito das relações domésticas e familiares no sentido de resguardá-las de toda forma de negligência, discriminação, exploração, violência, crueldade e opressão.

$\S 2^{\circ}$ Cabe à família, à sociedade e ao poder público criar as condições necessárias para o efetivo exercício dos direitos enunciados no caput.

Art. $4^{\circ} \mathrm{Na}$ interpretação desta Lei, serão considerados os fins sociais a que ela se destina e, especialmente, as condições peculiares das mulheres em situação de violência doméstica e familiar. 


\section{TÍTULO II}

\section{DA VIOLÊNCIA DOMÉSTICA E FAMILIAR CONTRA A MULHER CAPÍTULO I}

\section{DISPOSIÇÕES GERAIS}

Art. $5^{\circ}$ Para os efeitos desta Lei, configura violência doméstica e familiar contra a mulher qualquer ação ou omissão baseada no gênero que lhe cause morte, lesão, sofrimento físico, sexual ou psicológico e dano moral ou patrimonial:

I - no âmbito da unidade doméstica, compreendida como o espaço de convívio permanente de pessoas, com ou sem vínculo familiar, inclusive as esporadicamente agregadas;

II - no âmbito da família, compreendida como a comunidade formada por indivíduos que são ou se consideram aparentados, unidos por laços naturais, por afinidade ou por vontade expressa;

III - em qualquer relação íntima de afeto, na qual o agressor conviva ou tenha convivido com a ofendida, independentemente de coabitação.

Parágrafo único. As relações pessoais enunciadas neste artigo independem de orientação sexual.

Art. $6^{\circ}$ A violência doméstica e familiar contra a mulher constitui uma das formas de violação dos direitos humanos.

\section{CAPÍTULO II}

\section{DAS FORMAS DE VIOLÊNCIA DOMÉSTICA E FAMILIAR}

\section{CONTRA A MULHER}

Art. $7^{\circ}$ São formas de violência doméstica e familiar contra a mulher, entre outras:

I - a violência física, entendida como qualquer conduta que ofenda sua integridade ou saúde corporal;

II - a violência psicológica, entendida como qualquer conduta que lhe cause dano emocional e diminuição da auto-estima ou que lhe prejudique e perturbe o pleno desenvolvimento ou que vise degradar ou controlar suas ações, comportamentos, crenças e decisões, mediante ameaça, constrangimento, humilhação, manipulação, isolamento, vigilância constante, perseguição contumaz, insulto, chantagem, ridicularização, exploração e limitação do direito de ir e vir ou qualquer outro meio que lhe cause prejuízo à saúde psicológica e à autodeterminação;

III - a violência sexual, entendida como qualquer conduta que a constranja a presenciar, a manter ou a participar de relação sexual não desejada, mediante intimidação, ameaça, coação ou uso da força; que a induza a comercializar ou a utilizar, de qualquer modo, a sua sexualidade, que a impeça de usar qualquer método contraceptivo ou que a force ao matrimônio, à gravidez, ao aborto ou à prostituição, mediante coação, chantagem, suborno ou manipulação; ou que limite ou anule o exercício de seus direitos sexuais e reprodutivos;

IV - a violência patrimonial, entendida como qualquer conduta que configure retenção, subtração, destruição parcial ou total de seus objetos, instrumentos de trabalho, documentos 
pessoais, bens, valores e direitos ou recursos econômicos, incluindo os destinados a satisfazer suas necessidades;

$\mathrm{V}$ - a violência moral, entendida como qualquer conduta que configure calúnia, difamação ou injúria.

\section{TÍTULO III}

\section{DA ASSISTÊNCIA À MULHER EM SITUAÇÃO DE VIOLÊNCIA DOMÉSTICA E FAMILIAR \\ CAPÍTULO I}

\section{DAS MEDIDAS INTEGRADAS DE PREVENÇÃO}

Art. $8^{\circ}$ A política pública que visa coibir a violência doméstica e familiar contra a mulher farse-á por meio de um conjunto articulado de ações da União, dos Estados, do Distrito Federal e dos Municípios e de ações não-governamentais, tendo por diretrizes:

I - a integração operacional do Poder Judiciário, do Ministério Público e da Defensoria Pública com as áreas de segurança pública, assistência social, saúde, educação, trabalho e habitação;

II - a promoção de estudos e pesquisas, estatísticas e outras informações relevantes, com a perspectiva de gênero e de raça ou etnia, concernentes às causas, às conseqüências e à frequiência da violência doméstica e familiar contra a mulher, para a sistematização de dados, a serem unificados nacionalmente, e a avaliação periódica dos resultados das medidas adotadas;

III - o respeito, nos meios de comunicação social, dos valores éticos e sociais da pessoa e da família, de forma a coibir os papéis estereotipados que legitimem ou exacerbem a violência doméstica e familiar, de acordo com o estabelecido no inciso III do art. $1^{\circ}$, no inciso IV do art. $3^{\circ}$ e no inciso IV do art. 221 da Constituição Federal;

IV - a implementação de atendimento policial especializado para as mulheres, em particular nas Delegacias de Atendimento à Mulher;

V - a promoção e a realização de campanhas educativas de prevenção da violência doméstica e familiar contra a mulher, voltadas ao público escolar e à sociedade em geral, e a difusão desta Lei e dos instrumentos de proteção aos direitos humanos das mulheres;

VI - a celebração de convênios, protocolos, ajustes, termos ou outros instrumentos de promoção de parceria entre órgãos governamentais ou entre estes e entidades nãogovernamentais, tendo por objetivo a implementação de programas de erradicação da violência doméstica e familiar contra a mulher;

VII - a capacitação permanente das Polícias Civil e Militar, da Guarda Municipal, do Corpo de Bombeiros e dos profissionais pertencentes aos órgãos e às áreas enunciados no inciso I quanto às questões de gênero e de raça ou etnia;

VIII - a promoção de programas educacionais que disseminem valores éticos de irrestrito respeito à dignidade da pessoa humana com a perspectiva de gênero e de raça ou etnia; 
IX - o destaque, nos currículos escolares de todos os níveis de ensino, para os conteúdos relativos aos direitos humanos, à eqüidade de gênero e de raça ou etnia e ao problema da violência doméstica e familiar contra a mulher.

\section{CAPÍTULO II}

\section{DA ASSISTÊNCIA À MULHER EM SITUAÇÃO DE VIOLÊNCIA DOMÉSTICA E FAMILIAR}

Art. $9^{\circ}$ A assistência à mulher em situação de violência doméstica e familiar será prestada de forma articulada e conforme os princípios e as diretrizes previstos na Lei Orgânica da Assistência Social, no Sistema Único de Saúde, no Sistema Único de Segurança Pública, entre outras normas e políticas públicas de proteção, e emergencialmente quando for o caso.

$\S 1^{\circ}$ O juiz determinará, por prazo certo, a inclusão da mulher em situação de violência doméstica e familiar no cadastro de programas assistenciais do governo federal, estadual e municipal.

$\S 2^{\circ} \mathrm{O}$ juiz assegurará à mulher em situação de violência doméstica e familiar, para preservar sua integridade física e psicológica:

I - acesso prioritário à remoção quando servidora pública, integrante da administração direta ou indireta;

II - manutenção do vínculo trabalhista, quando necessário o afastamento do local de trabalho, por até seis meses.

$\S 3^{\circ}$ A assistência à mulher em situação de violência doméstica e familiar compreenderá o acesso aos benefícios decorrentes do desenvolvimento científico e tecnológico, incluindo os serviços de contracepção de emergência, a profilaxia das Doenças Sexualmente Transmissíveis (DST) e da Síndrome da Imunodeficiência Adquirida (AIDS) e outros procedimentos médicos necessários e cabíveis nos casos de violência sexual.

\section{CAPÍTULO III}

\section{DO ATENDIMENTO PELA AUTORIDADE POLICIAL}

Art. 10. Na hipótese da iminência ou da prática de violência doméstica e familiar contra a mulher, a autoridade policial que tomar conhecimento da ocorrência adotará, de imediato, as providências legais cabíveis.

Parágrafo único. Aplica-se o disposto no caput deste artigo ao descumprimento de medida protetiva de urgência deferida.

Art. 11. No atendimento à mulher em situação de violência doméstica e familiar, a autoridade policial deverá, entre outras providências:

I - garantir proteção policial, quando necessário, comunicando de imediato ao Ministério Público e ao Poder Judiciário;

II - encaminhar a ofendida ao hospital ou posto de saúde e ao Instituto Médico Legal;

III - fornecer transporte para a ofendida e seus dependentes para abrigo ou local seguro, quando houver risco de vida; 
IV - se necessário, acompanhar a ofendida para assegurar a retirada de seus pertences do local da ocorrência ou do domicílio familiar;

V - informar à ofendida os direitos a ela conferidos nesta Lei e os serviços disponíveis.

Art. 12. Em todos os casos de violência doméstica e familiar contra a mulher, feito o registro da ocorrência, deverá a autoridade policial adotar, de imediato, os seguintes procedimentos, sem prejuízo daqueles previstos no Código de Processo Penal:

I - ouvir a ofendida, lavrar o boletim de ocorrência e tomar a representação a termo, se apresentada;

II - colher todas as provas que servirem para o esclarecimento do fato e de suas circunstâncias;

III - remeter, no prazo de 48 (quarenta e oito) horas, expediente apartado ao juiz com o pedido da ofendida, para a concessão de medidas protetivas de urgência;

IV - determinar que se proceda ao exame de corpo de delito da ofendida e requisitar outros exames periciais necessários;

V - ouvir o agressor e as testemunhas;

VI - ordenar a identificação do agressor e fazer juntar aos autos sua folha de antecedentes criminais, indicando a existência de mandado de prisão ou registro de outras ocorrências policiais contra ele;

VII - remeter, no prazo legal, os autos do inquérito policial ao juiz e ao Ministério Público.

$\S 1^{\circ}$ O pedido da ofendida será tomado a termo pela autoridade policial e deverá conter:

I - qualificação da ofendida e do agressor;

II - nome e idade dos dependentes;

III - descrição sucinta do fato e das medidas protetivas solicitadas pela ofendida.

$\S 2^{\circ}$ A autoridade policial deverá anexar ao documento referido no $\S 1^{\circ}$ o boletim de ocorrência e cópia de todos os documentos disponíveis em posse da ofendida.

$\S 3^{\circ}$ Serão admitidos como meios de prova os laudos ou prontuários médicos fornecidos por hospitais e postos de saúde.

\section{TÍTULO IV}

\section{DOS PROCEDIMENTOS}

\section{CAPÍTULO I}

\section{DISPOSIÇÕES GERAIS}

Art. 13. Ao processo, ao julgamento e à execução das causas cíveis e criminais decorrentes da prática de violência doméstica e familiar contra a mulher aplicar-se-ão as normas dos Códigos de Processo Penal e Processo Civil e da legislação específica relativa à criança, ao adolescente e ao idoso que não conflitarem com o estabelecido nesta Lei. 
Art. 14. Os Juizados de Violência Doméstica e Familiar contra a Mulher, órgãos da Justiça Ordinária com competência cível e criminal, poderão ser criados pela União, no Distrito Federal e nos Territórios, e pelos Estados, para o processo, o julgamento e a execução das causas decorrentes da prática de violência doméstica e familiar contra a mulher.

Parágrafo único. Os atos processuais poderão realizar-se em horário noturno, conforme dispuserem as normas de organização judiciária.

Art. 15. É competente, por opção da ofendida, para os processos cíveis regidos por esta Lei, o Juizado:

I - do seu domicílio ou de sua residência;

II - do lugar do fato em que se baseou a demanda;

III - do domicílio do agressor.

Art. 16. Nas ações penais públicas condicionadas à representação da ofendida de que trata esta Lei, só será admitida a renúncia à representação perante o juiz, em audiência especialmente designada com tal finalidade, antes do recebimento da denúncia e ouvido o Ministério Público.

Art. 17. É vedada a aplicação, nos casos de violência doméstica e familiar contra a mulher, de penas de cesta básica ou outras de prestação pecuniária, bem como a substituição de pena que implique o pagamento isolado de multa.

\section{CAPÍTULO II}

\section{DAS MEDIDAS PROTETIVAS DE URGÊNCIA}

\section{Seção I}

\section{Disposições Gerais}

Art. 18. Recebido o expediente com o pedido da ofendida, caberá ao juiz, no prazo de 48 (quarenta e oito) horas:

I - conhecer do expediente e do pedido e decidir sobre as medidas protetivas de urgência;

II - determinar o encaminhamento da ofendida ao órgão de assistência judiciária, quando for o caso;

III - comunicar ao Ministério Público para que adote as providências cabíveis.

Art. 19. As medidas protetivas de urgência poderão ser concedidas pelo juiz, a requerimento do Ministério Público ou a pedido da ofendida.

$\S 1^{\mathrm{o}}$ As medidas protetivas de urgência poderão ser concedidas de imediato, independentemente de audiência das partes e de manifestação do Ministério Público, devendo este ser prontamente comunicado.

$\S 2^{\circ}$ As medidas protetivas de urgência serão aplicadas isolada ou cumulativamente, e poderão ser substituídas a qualquer tempo por outras de maior eficácia, sempre que os direitos reconhecidos nesta Lei forem ameaçados ou violados. 
$\S 3^{\circ}$ Poderá o juiz, a requerimento do Ministério Público ou a pedido da ofendida, conceder novas medidas protetivas de urgência ou rever aquelas já concedidas, se entender necessário à proteção da ofendida, de seus familiares e de seu patrimônio, ouvido o Ministério Público.

Art. 20. Em qualquer fase do inquérito policial ou da instrução criminal, caberá a prisão preventiva do agressor, decretada pelo juiz, de ofício, a requerimento do Ministério Público ou mediante representação da autoridade policial.

Parágrafo único. O juiz poderá revogar a prisão preventiva se, no curso do processo, verificar a falta de motivo para que subsista, bem como de novo decretá-la, se sobrevierem razões que a justifiquem.

Art. 21. A ofendida deverá ser notificada dos atos processuais relativos ao agressor, especialmente dos pertinentes ao ingresso e à saída da prisão, sem prejuízo da intimação do advogado constituído ou do defensor público.

Parágrafo único. A ofendida não poderá entregar intimação ou notificação ao agressor.

\section{Seção II}

\section{Das Medidas Protetivas de Urgência que Obrigam o Agressor}

Art. 22. Constatada a prática de violência doméstica e familiar contra a mulher, nos termos desta Lei, o juiz poderá aplicar, de imediato, ao agressor, em conjunto ou separadamente, as seguintes medidas protetivas de urgência, entre outras:

I - suspensão da posse ou restrição do porte de armas, com comunicação ao órgão competente, nos termos da Lei ${ }^{\circ} 10.826$, de 22 de dezembro de 2003;

II - afastamento do lar, domicílio ou local de convivência com a ofendida;

III - proibição de determinadas condutas, entre as quais:

a) aproximação da ofendida, de seus familiares e das testemunhas, fixando o limite mínimo de distância entre estes e o agressor;

b) contato com a ofendida, seus familiares e testemunhas por qualquer meio de comunicação;

c) freqüentação de determinados lugares a fim de preservar a integridade física e psicológica da ofendida;

IV - restrição ou suspensão de visitas aos dependentes menores, ouvida a equipe de atendimento multidisciplinar ou serviço similar;

V - prestação de alimentos provisionais ou provisórios.

$\S 1^{\circ}$ As medidas referidas neste artigo não impedem a aplicação de outras previstas na legislação em vigor, sempre que a segurança da ofendida ou as circunstâncias o exigirem, devendo a providência ser comunicada ao Ministério Público.

$\S 2^{\circ} \mathrm{Na}$ hipótese de aplicação do inciso I, encontrando-se o agressor nas condições mencionadas no caput e incisos do art. $6^{\circ}$ da Lei ${ }^{\circ} 10.826$, de 22 de dezembro de 2003, o juiz comunicará ao respectivo órgão, corporação ou instituição as medidas protetivas de urgência concedidas e determinará a restrição do porte de armas, ficando o superior imediato do 
agressor responsável pelo cumprimento da determinação judicial, sob pena de incorrer nos crimes de prevaricação ou de desobediência, conforme o caso.

$\S 3^{\circ}$ Para garantir a efetividade das medidas protetivas de urgência, poderá o juiz requisitar, a qualquer momento, auxílio da força policial.

$\S 4^{\circ}$ Aplica-se às hipóteses previstas neste artigo, no que couber, o disposto no caput e nos $\S \S$ $5^{\circ}$ e $6^{\circ}$ do art. 461 da Lei no 5.869, de 11 de janeiro de 1973 (Código de Processo Civil).

\section{Seção III}

\section{Das Medidas Protetivas de Urgência à Ofendida}

Art. 23. Poderá o juiz, quando necessário, sem prejuízo de outras medidas:

I - encaminhar a ofendida e seus dependentes a programa oficial ou comunitário de proteção ou de atendimento;

II - determinar a recondução da ofendida e a de seus dependentes ao respectivo domicílio, após afastamento do agressor;

III - determinar o afastamento da ofendida do lar, sem prejuízo dos direitos relativos a bens, guarda dos filhos e alimentos;

IV - determinar a separação de corpos.

Art. 24. Para a proteção patrimonial dos bens da sociedade conjugal ou daqueles de propriedade particular da mulher, o juiz poderá determinar, liminarmente, as seguintes medidas, entre outras:

I - restituição de bens indevidamente subtraídos pelo agressor à ofendida;

II - proibição temporária para a celebração de atos e contratos de compra, venda e locação de propriedade em comum, salvo expressa autorização judicial;

III - suspensão das procurações conferidas pela ofendida ao agressor;

IV - prestação de caução provisória, mediante depósito judicial, por perdas e danos materiais decorrentes da prática de violência doméstica e familiar contra a ofendida.

Parágrafo único. Deverá o juiz oficiar ao cartório competente para os fins previstos nos incisos II e III deste artigo.

\section{CAPÍTULO III}

\section{DA ATUAÇÃO DO MINISTÉRIO PÚBLICO}

Art. 25. O Ministério Público intervirá, quando não for parte, nas causas cíveis e criminais decorrentes da violência doméstica e familiar contra a mulher.

Art. 26. Caberá ao Ministério Público, sem prejuízo de outras atribuições, nos casos de violência doméstica e familiar contra a mulher, quando necessário:

I - requisitar força policial e serviços públicos de saúde, de educação, de assistência social e de segurança, entre outros; 
II - fiscalizar os estabelecimentos públicos e particulares de atendimento à mulher em situação de violência doméstica e familiar, e adotar, de imediato, as medidas administrativas ou judiciais cabíveis no tocante a quaisquer irregularidades constatadas;

III - cadastrar os casos de violência doméstica e familiar contra a mulher.

\section{CAPÍTULO IV}

\section{DA ASSISTÊNCIA JUDICIÁRIA}

Art. 27. Em todos os atos processuais, cíveis e criminais, a mulher em situação de violência doméstica e familiar deverá estar acompanhada de advogado, ressalvado o previsto no art. 19 desta Lei.

Art. 28. É garantido a toda mulher em situação de violência doméstica e familiar o acesso aos serviços de Defensoria Pública ou de Assistência Judiciária Gratuita, nos termos da lei, em sede policial e judicial, mediante atendimento específico e humanizado.

\section{TÍTULO V}

\section{DA EQUIPE DE ATENDIMENTO MULTIDISCIPLINAR}

Art. 29. Os Juizados de Violência Doméstica e Familiar contra a Mulher que vierem a ser criados poderão contar com uma equipe de atendimento multidisciplinar, a ser integrada por profissionais especializados nas áreas psicossocial, jurídica e de saúde.

Art. 30. Compete à equipe de atendimento multidisciplinar, entre outras atribuições que lhe forem reservadas pela legislação local, fornecer subsídios por escrito ao juiz, ao Ministério Público e à Defensoria Pública, mediante laudos ou verbalmente em audiência, e desenvolver trabalhos de orientação, encaminhamento, prevenção e outras medidas, voltados para a ofendida, o agressor e os familiares, com especial atenção às crianças e aos adolescentes.

Art. 31. Quando a complexidade do caso exigir avaliação mais aprofundada, o juiz poderá determinar a manifestação de profissional especializado, mediante a indicação da equipe de atendimento multidisciplinar.

Art. 32. O Poder Judiciário, na elaboração de sua proposta orçamentária, poderá prever recursos para a criação e manutenção da equipe de atendimento multidisciplinar, nos termos da Lei de Diretrizes Orçamentárias.

\section{TÍTULO VI \\ DISPOSIÇÕES TRANSITÓRIAS}

Art. 33. Enquanto não estruturados os Juizados de Violência Doméstica e Familiar contra a Mulher, as varas criminais acumularão as competências cível e criminal para conhecer e julgar as causas decorrentes da prática de violência doméstica e familiar contra a mulher, observadas as previsões do Título IV desta Lei, subsidiada pela legislação processual pertinente.

Parágrafo único. Será garantido o direito de preferência, nas varas criminais, para o processo e o julgamento das causas referidas no caput.

\section{TÍTULO VII}




\section{DISPOSIÇÕES FINAIS}

Art. 34. A instituição dos Juizados de Violência Doméstica e Familiar contra a Mulher poderá ser acompanhada pela implantação das curadorias necessárias e do serviço de assistência judiciária.

Art. 35. A União, o Distrito Federal, os Estados e os Municípios poderão criar e promover, no limite das respectivas competências:

I - centros de atendimento integral e multidisciplinar para mulheres e respectivos dependentes em situação de violência doméstica e familiar;

II - casas-abrigos para mulheres e respectivos dependentes menores em situação de violência doméstica e familiar;

III - delegacias, núcleos de defensoria pública, serviços de saúde e centros de perícia médicolegal especializados no atendimento à mulher em situação de violência doméstica e familiar;

IV - programas e campanhas de enfrentamento da violência doméstica e familiar;

V - centros de educação e de reabilitação para os agressores.

Art. 36. A União, os Estados, o Distrito Federal e os Municípios promoverão a adaptação de seus órgãos e de seus programas às diretrizes e aos princípios desta Lei.

Art. 37. A defesa dos interesses e direitos transindividuais previstos nesta Lei poderá ser exercida, concorrentemente, pelo Ministério Público e por associação de atuação na área, regularmente constituída há pelo menos um ano, nos termos da legislação civil.

Parágrafo único. O requisito da pré-constituição poderá ser dispensado pelo juiz quando entender que não há outra entidade com representatividade adequada para o ajuizamento da demanda coletiva.

Art. 38. As estatísticas sobre a violência doméstica e familiar contra a mulher serão incluídas nas bases de dados dos órgãos oficiais do Sistema de Justiça e Segurança a fim de subsidiar o sistema nacional de dados e informações relativo às mulheres.

Parágrafo único. As Secretarias de Segurança Pública dos Estados e do Distrito Federal poderão remeter suas informações criminais para a base de dados do Ministério da Justiça.

Art. 39. A União, os Estados, o Distrito Federal e os Municípios, no limite de suas competências e nos termos das respectivas leis de diretrizes orçamentárias, poderão estabelecer dotações orçamentárias específicas, em cada exercício financeiro, para a implementação das medidas estabelecidas nesta Lei.

Art. 40. As obrigações previstas nesta Lei não excluem outras decorrentes dos princípios por ela adotados.

Art. 41. Aos crimes praticados com violência doméstica e familiar contra a mulher, independentemente da pena prevista, não se aplica a Lei $n^{\circ}$ 9.099, de 26 de setembro de 1995.

Art. 42. O art. 313 do Decreto-Lei n ${ }^{0}$ 3.689, de 3 de outubro de 1941 (Código de Processo Penal), passa a vigorar acrescido do seguinte inciso IV:

“Art. 313. 
IV - se o crime envolver violência doméstica e familiar contra a mulher, nos termos da lei específica, para garantir a execução das medidas protetivas de urgência.” (NR)

Art. 43. A alínea f do inciso II do art. 61 do Decreto-Lei $\mathrm{n}^{\circ} 2.848$, de 7 de dezembro de 1940 (Código Penal), passa a vigorar com a seguinte redação:

“Art. 61.

II -

f) com abuso de autoridade ou prevalecendo-se de relações domésticas, de coabitação ou de hospitalidade, ou com violência contra a mulher na forma da lei específica;

$$
\text { " (NR) }
$$

Art. 44. O art. 129 do Decreto-Lei ${ }^{\circ}$ 2.848, de 7 de dezembro de 1940 (Código Penal), passa a vigorar com as seguintes alterações:

"Art. 129.

$\S 9^{\circ}$ Se a lesão for praticada contra ascendente, descendente, irmão, cônjuge ou companheiro, ou com quem conviva ou tenha convivido, ou, ainda, prevalecendo-se o agente das relações domésticas, de coabitação ou de hospitalidade:

Pena - detenção, de 3 (três) meses a 3 (três) anos.

$\S 11$. Na hipótese do $\S 9^{\circ}$ deste artigo, a pena será aumentada de um terço se o crime for cometido contra pessoa portadora de deficiência." (NR)

Art. 45. O art. 152 da Lei $n^{0}$ 7.210, de 11 de julho de 1984 (Lei de Execução Penal), passa a vigorar com a seguinte redação:

"Art. 152.

Parágrafo único. Nos casos de violência doméstica contra a mulher, o juiz poderá determinar o comparecimento obrigatório do agressor a programas de recuperação e reeducação." (NR)

Art. 46. Esta Lei entra em vigor 45 (quarenta e cinco) dias após sua publicação.

Brasília, 7 de agosto de 2006; $185^{\circ}$ da Independência e $118^{\circ}$ da República.

LUIZ INÁCIO LULA DA SILVA

Dilma Rousseff 